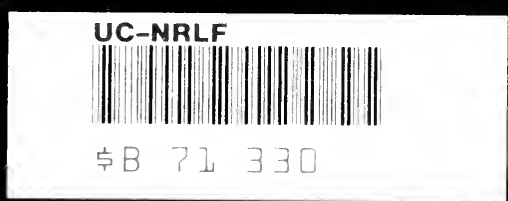




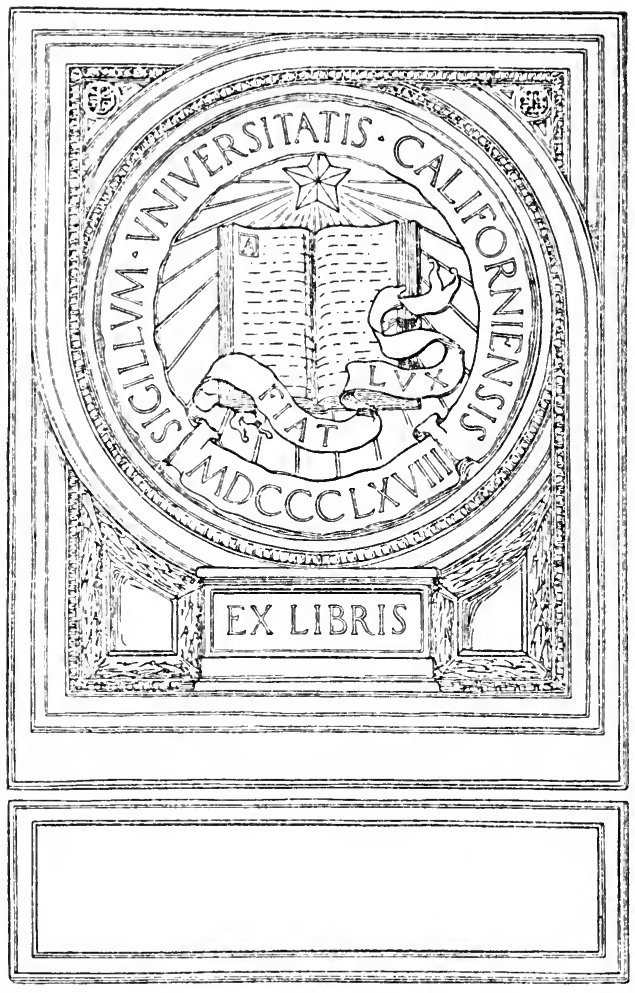


(1)

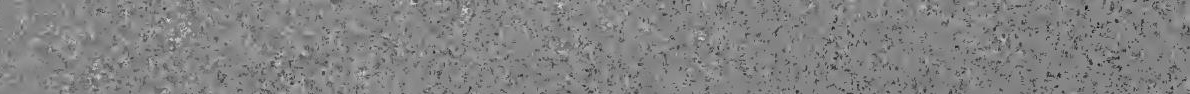

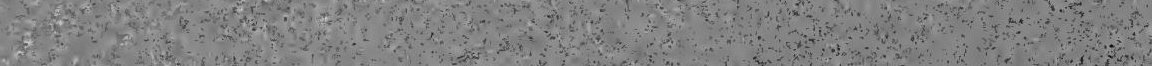

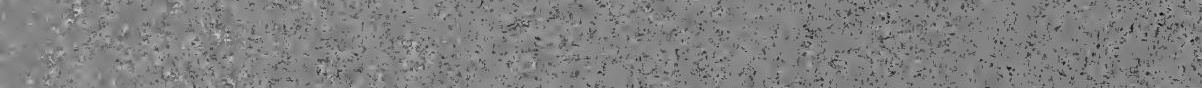

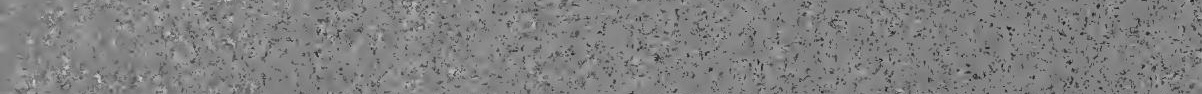

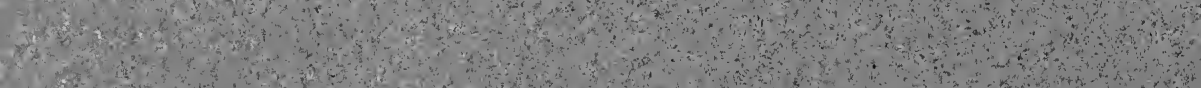
$4040+2+2$

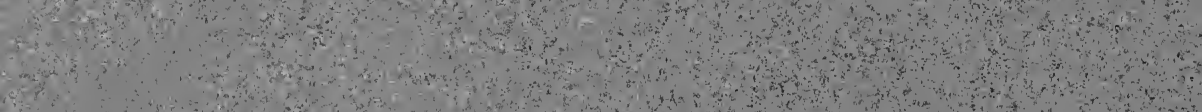

(1)

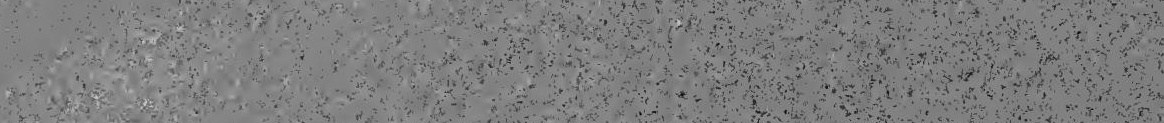

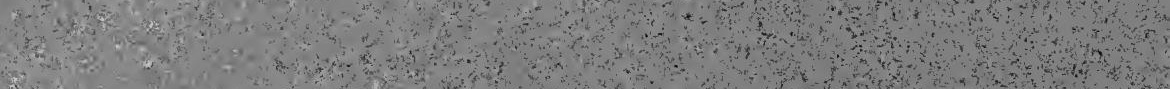
3.

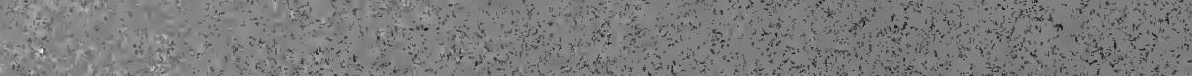

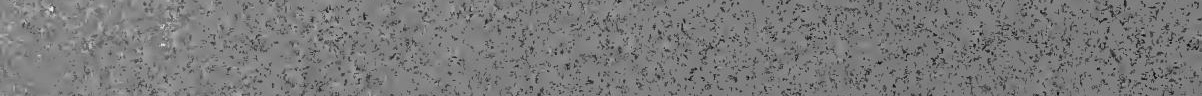

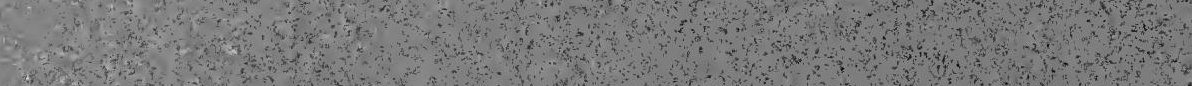

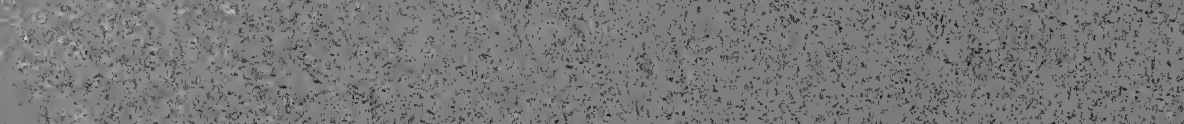

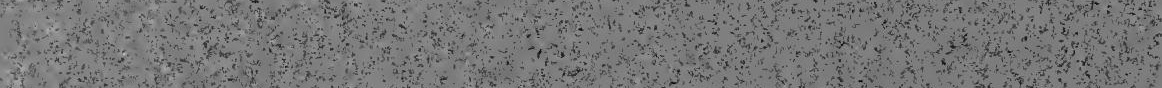

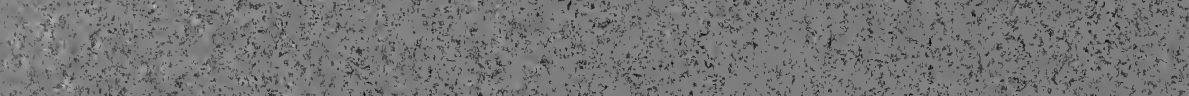

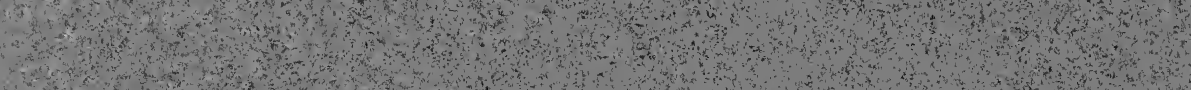
4
$H$

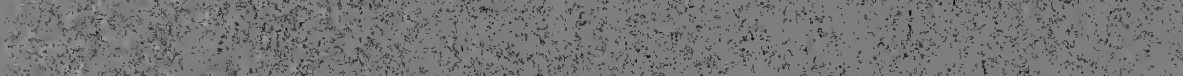
(1)
$\because$

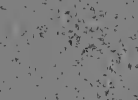
$\therefore \cdots$ 




\section{PURE MILK}

ANT THI:

\section{PUBLIC HEALTH}

A MANLAI, OH

\section{Milk and Dairy Inspection}

BY ARCHIBALD ROBINSON WARD, B.S. A., D. V. M.

Assistant Professor of Bacteriology and Director of the state Hyicuic Iaboratory. Iniversity of California, Berkeley, California.

WITH TWO CHAP'IFRS

BY MYER EDWARD JAFFA, M.S.

Professor of Nutrition and Director of the state Food and Drug I abonatory.

Iniversity of Califormia.

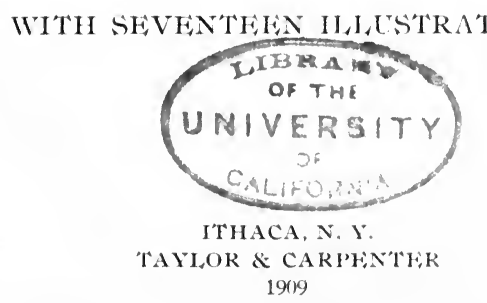




\section{GENERAL}

COpyright 1909

BY TAYLOR A CARPENTER 
TO

VERANUS ALVA MOORE

WHOSE INSPIRING WORK AS A TEACHER AND INVESTIGATOR IN THE FIELD OF COMPARATIVE PATHOIOGY AND BACTERIOLOGY IS EXERTING A PROFOUND INFLUENCE IN UPLIFTING THE VETERINARY PROFESSION, THIS BOOK IS DEIDICATED. 

The relation of milk to the public health and the neans employed to ensure a safe milk supply is a subject of varied aspects. The proper control of the public milk supply requires more or less of the services of the bacteriologist, the clemist, the physician, the veterinarian, and the progressive dairyman. The ordinary fund of technical knowledge possessed by any one of these classes is not sufficient for coping with the difficulties encountered in carrying on efficient and compreliensive measures for milk and dairy inspection. Furtherniore, knowledge concerning the subject is being rapidly increased by contributions widely scattered in technical journals.

The writer has attempted the difficult task of assembling the essential facts for the information of the health officer and others directly concerned in the crusade for better milk. The class of individuals particularly addressed is such, that a general knowledge of bacteriology is assumed to be possessed by the reader.

Each chapter is accompanied by a list of references bearing on the subjects discussed. Throughout the text, numbers in parenthesis, referring to the authorities given at the end of the chapter, have been freely used. These references serve in some cases to give statements greater weight than a mere unsupported personal opinion would have, and in all cases permit those particularly interested to gain access readily to the details concerning the points at issue.

In the preparation of the book, the writer has become greatly obligated to his colleague, Professor M. E. Jaffa, for writing chapters X and XI. With reference to those chapters, Professor Jaffa desires to have it stated that he has not attempted to present the details of the more common methods employed in the chemical examination of milk. This branch of milk inspection is the most advanced and the methods are well established. He has been content to indicate what should be done 
and to refer to standard works on the subject for the methods except in the case of some of the simple tests.

Dr. William H. Boynton, Assistant in Pathology and Bacteriology, New York State Veterinary College, has very generously permitted the use of the photographs appearing as figures 13 and 14, together with his description of them, in advance of publication by himself. Professor G. C. Watson, General Manager of the Tully Farms, Tully, N. Y., has kindly permitted the use of photographs appearing as figures 3 and 4 . Dr. Francis H. Slack, Chairman of the Committee of the American Public Health Association on Standard Methods of Bacterial Milk Analysis, has rendered assistance by furnishing a manuscript copy of the 1908 report of that Committee. Specific acknowledgement as to sources of information has been made largely throughout the text by means of the system of references employed.

It is not safe to indulge in the hope that important work has not been overlooked, or that new facts may not require a modification of attitude towards certain troublesome problems. Therefore, assistance tending to improve the book will be gratefully received.

A. R. W. 


\section{TABLE OF CONTENTS.}

CHAP'TER I.

THF CONTAMINATION OF MII,K.

Erderer

Character of bacteria

Significance

Foremilk

Coat of animal

Exterior of udller.

shliape of milk pail

$\checkmark$ Tlie ni1lker

Milking machines

vitalsle

Floor
Mangers and stanclions

Mangers and stanchions $\quad 11$

Barn inprovenients $\quad 11$

Feeding

s.pecial nilking roonss 12

Cleansing of utensils....... 13

Scalding .... ... 13

Construction of utensils. .... 15

Mlandling milk _................ 15

Bottling n11ilk $\ldots 16$

Milk room $\quad 16$

S.1)elivery of milk.. 16

Milk flavors $\quad 17$

Sediments.. 17

References ... _... 18

CHAP'TER II.

CHANGES IN MII,K CAUSED BY BACTERIA.

Significance of bacterial contanination

Numbers of bacteria in rilarket milk .......... 24

Eiffect of temperature on bacterial growth ................. 24

$\checkmark$ Methods of cooling ............................... 25

$\sim$ Milk during transportation .......................... 25

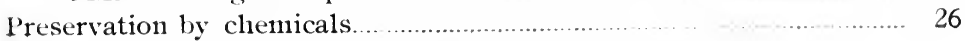


Lactic acid fermentation

Putrefactive processes.

Organisms causing putrefaction

Antagonism of lactic acid fermentation

Conditions controlling putrefaction

Source of putrefactive organisms

'Toxic milk

Ropy milk

Cause of ropy nililk

Biological characteristics of P. lactis a'iscosus 32

Sources of contanination of milk

Neans of combating ropy milk ... 33

Germicidal activity

References

CHAPTER III.

EPIDEMIC DISFASES TRANSMITTEID BY MIIK.

Transmission of diseases of man by milk.

Cliaracter of milk-borne epilemics

Typhoid fever

Investigations in the District of Columbia.

Importance of milk as a carrier

Sources of the contamination of milk

Detection of milk-borne typhoid fever epiclemics

Berkeley, Cal., outbreak ............................ 49

Diplitheria

Recognition of milk-borne diphtheria epidemics.

Milk-borne diplıtheria in Oroville, Cal.

Scarlet fever

\section{CHAP'TER IV.}

BOVINE TUBERCLLOSIS AND OTHER CATTLE DISFASES.

Bovine tuberculosis

Losses to the live stock industry.

Transmission by milk

Infection of swine

Insidious onset

Conditions governing prevalence

Prevalence in herds.

Contamination of milk by tubercle bacilli.

Tubercle bacilli in market milk

Human and bovine types of tubercle bacilli 
Views of Kocl

Bovine tubercle bacilli in m11an.......... 64

Intermediate types of tubercle bacilli 65

Channels of infection .............. 65

International Congress of $1908 \quad 66$

Tuberculosis in Japan _.. 66

P'resent status of controversy $\quad 67$

$\begin{array}{ll}\text { Protection of the milk supply } & 67\end{array}$

$\begin{array}{ll}\text { Measures against bovine tuberculosis } & 67\end{array}$

Physical examination $\quad 68$

$\begin{array}{ll}\text { Tuberculin test } & 71\end{array}$

New tests for tuberculosis $\quad 72$

Stable sanitation and tuberculosis $\quad 72$

Tuberculin test ordinances..

Clean herds the goal $\quad 73$

The Waslington plan $\quad 73$

Test by city official _... 75

l'est by any licensed reterinarian $\quad 76$

Milk contracts $\quad 76$

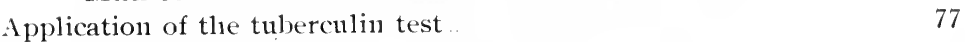

Temporary numbers $\quad 77$

Facilitating observations of temperatures $\quad 77$

Injection witl tuberculin ..... 79

Temperatures after injection $\quad 79$

$\begin{array}{ll}\text { Interpretation of temperatures } & 79\end{array}$

Limitations of tuberculin test $\quad 79$

Fraud 80

Permanent identification of animals . 80

Disposal of tubercular animals $\quad 82$

Disinfection ....................... 85

Filucation of dairymen concerning bovine tuberculosis $\quad 85$

Anthrax ... .......... 86

Suppuration $\quad 86$

$\begin{array}{ll}\text { Cowpox … } & 87\end{array}$

$\begin{array}{ll}\text { Parturition disturbances .. } & 87\end{array}$

$\begin{array}{ll}\text { Malta fever... } & 87\end{array}$

Foot and moutl disease $\quad 88$

Milk-sickness $\quad 88$

References $\quad 89$

CHAP'TER V.

MUNICIPAL, SANITARY CONTROL OF MII,K.

Control of milk supply. .... 93

Inspection. . . . . 93

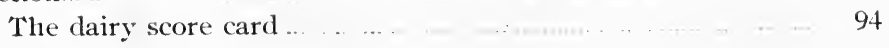


Improvennent in Richn1ond, Va.

Waslington milk supply

Educational activities

Inspection of cows

Inspection of dairy apparatus

Inspection of water supply

Scope of inspection

$\begin{array}{ll}\text { The score card for city milk plants } & 106\end{array}$

Milk-borne epidemics . 109

$\begin{array}{ll}\text { Temperature standard } & 109\end{array}$

Numerical determinations of bacteria in $111 \mathrm{k} \quad 110$

Frlucation of the public $\quad 112$

References

\section{CHAP'TER VI.}

PASTELRIZATION OF MIIK.

General definition

Incentives for pasteurization

Conditions required for killing bacteria

Bacterium tuberculosis

Alteration of milk by heat.

Cooked taste

Alterations of nilik constituents

Creaming quality

Vital qualities of milk

Spore-bearing bacteria

Bactericidal efficiency

Low-temperature pasteurization.

High-temperature pasteurization

Commercial pasteurization

Efficiency

Continuous-flow machines popular

Care subsequent to heating

mlasteurization in Chicago.

Pasteurized milk in infant feeding.

LPasteurization of nunicipal 111ilk supplies.

References

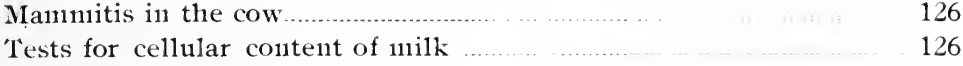

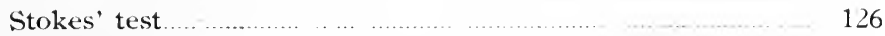

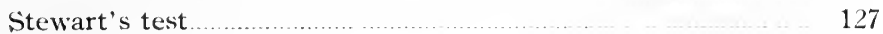


Slack's test

Doane-Buckley test

Savage's test

Tromminsdorff's test

significance of results

Streptococci in milk

Microccocci in 111ilk

Leucocytes in milk

\section{CHAP'TER VIII.}

BAC'ILRIOLOCICAL, HXAMINATION OF MIKK.

Numerical determination of bacteria $1+1$

Significance of results

Microscopic estimate of bacteria

Examinations for typloid fever and diphtheria bacilli. 152

'rubercle bacilli

Determination of streptococci

Qualitative determinations

\section{CHAP'TER IX.}

\section{CERTIFIED MILK}

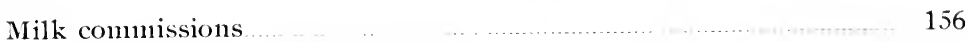

Association of milk commissions _................... 157

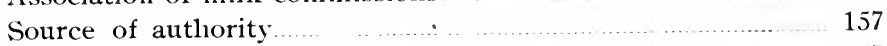

Field of milk commission activities ................. 157

Agreement with dairymen ... _.................. 158

Sanitary requirements for dairymen $\ldots \ldots \ldots \ldots \ldots$

Experts employed by milk commissions... … . . 164

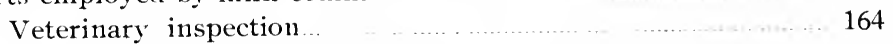

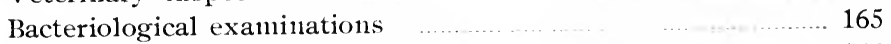

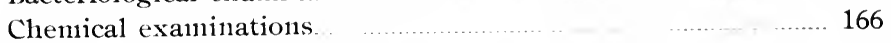

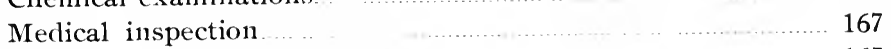

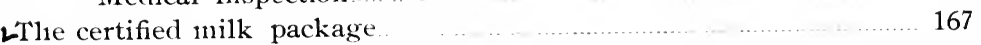

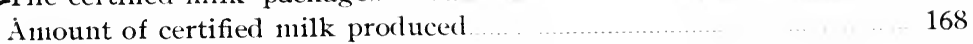

Fraudulent certified milk ............................................. 168

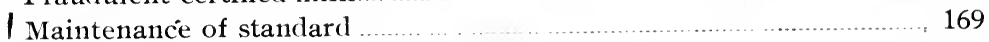

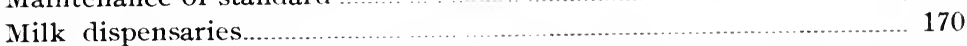

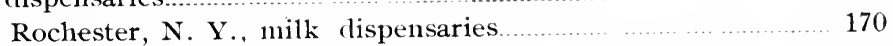

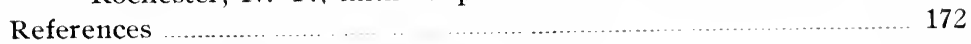


THE ANAISSIS OF MIIK.

Introduction

Composition of milk

Fffect of feeding on the composition of anilk

Fig. 1. Section of one quarter of the ulder of a cow 1

Fig. 2. Pearson's milk pail ...

Fig. 3. A convenient stable ...................... 10 
Fig. 4. Sterilizer containing racks for lolding bottles 14

Fig. 5. Ropy crean lifted with a fork 31

Fig. 6. Bacillus lactis riscosus. 31

Hig. 7. Germiciclal action of freshly drawn nilk

Fig. 8. Iaundry in which milk cans were washed 50

Fig. 9. Conditions surrounding a case of typloid fever 51

$\begin{array}{ll}\text { Fig. 10. Blank for recording temperatures } & 78\end{array}$

Fig. 11. Far-tag for marking cattle 80

Fig. 12. Card employed by the writer for the irlentification of cows 81

Fig. 13. Moak's card for identifying cows 83

Fig. 14. Diagran showing inprovement in clairy scores in Ricl1110nd, Va. 104

Fig. 15. Section of udler slowing epithelial cells 134

fig. 16. Section of udder showing epithelial cells and polynuclear leucocytes

Fig. 17. Cliart showing relation of municipal milk stations to infant 1110rtality

\section{APPENDICES.}

Appendix A. Dairy ordinance of Berkeley, Cal. 195

Appenclix B. Chicago tuberculin test ordinance 200

Appendix C. Duluth milk ordinance........ 206

Appendix I). Blank for reporting existence of infectious diseases. 211

Appendix F. Poster for dairy barus 212

Inclex 

$(5,25,27,28,47)$. The conclusions drawn from this line of work have been in substantial agreement upon the point that milk is contaminated before it reaches the teats. The subject is further treated in references $4,9,26,31,32,68$.

The number of bacteria found in the udder is less than would be expected elsewhere under similar conditions of food, moisture and temperature away from vital influences. The germicidal influence of fresh milk has been cited as an explanation of the fact $(25,28)$. The last of the milk drawn at any one milking contains less bacteria than that first drawn, but is seldom found to be sterile, if any but minute quantities are taken for examination. In fact, the "strippings" have been found to contain more bacteria per cc. than that drawn immediately before stripping. If a cow is not stripped,-that is, if a little milk is left in the udder,-the next milking will show a number of bacteria larger than usual. This fact has been explained by assuming that thorough milking removes the bacteria from the milk ducts more completely than the ordinary milking (60). It is evident that the few bacteria remaining in the ducts after milking constitute the source of the relatively larger numbers in the milk obtained during the fore and middle portions of the succeeding milking. It is not believed that the udder is subject to indiscriminate invasion by a variety of forms, but rather that the conditions found there are such as limit the bacterial flora. A number of attempts to colonize the udder with a variety of organisms have not met with success. Bacillus prodigiosus, an organism easily recognized in cultures by the red color, has been used several times with the result that inflammatory conditions have been set up. The observed persistence of this organism for twenty-two days, while the udder was inflamed, does not prove much, in view of the disease, and it was obtained in constantly decreasing numbers, which led to the conclusion that multiplication had not occurred (53). In one instance the teat of a goat was injected with $B$. prodigiosus and after slaughter, three days later, cultures showed that the organisms had invaded the udder (25). The fact that this particular organism is not an udder organism, and was used on account of its chromo- 
genic power, should be noted. Experiments with forms undoubtedly habituated to conditions within the udder have been made in very: few instances and further work along this line is desirable. The observed persistence of certain bacteria in certain particular quarters of the cow's udder from day to day is of significance $(26,66)$. The presence of bacteria in the udder is paralleled by the case of other mucous membranes. These facts render it uninecessary to look to hematogenous infection as the immediate source of the bacteria in the milk, even though bacteria have been demonstrated in other normal organs like: the spleen. (21). Such an explanation of the source of the bacteria would hardly account for the difference of the bacterial flora of different quarters of the udder. No evidence has been brought forward to substantiate the notion that the bacterial content of milk is influenced by bacteria in feed or water transferred via intestines, blood, and udder. Conclusions contradicting this view have been drawn from observations which have shown that the common bacterial flora of the udder is quite different from that of the intestines (26). Experiments have been made by feeding certain micro-organisms to cows and then searching for the same organisms in the milk, without succéss. The results might have been otherwise if care had not been taken to prevent contamination from the feces. One writer used B. prodigiosus (66), while another (26) used the same organism in one trial, and at another time used distillers' grains containing yeasts, oidium, proteus, bacilli, and streptococci. The bacterial content of milk drawn under aseptic precautions has been determined in cows fed on hay and on grass, and no difference was found in the numbers present in the milk (26). The' bacteria in feed and water may modify the bacterial content of the milk, but by other channels than through the interior of the udder.

Character of bacteria. The organisms most frequently found are micrococci, in general capable of producing visible changes in milk rather tardily (67), and hence they do not interfere with its apparent keeping quality. Conn, Esten and Stocking (11) have pointed out that one of these udder organisms (Micrococcus lactis varians) is the most common and widely distributed 
organism in milk, and have observed that it is identical with, or closely allied to, Micrococcus pyogenes aureus (staphylococcus pyogenes aureus). Willem and Minne likewise regard these organisms, found in freshly drawn milk, as $M$. pyogenes (68). Streptococci, indistinguishable from Streptococcus pyogenes, have been isolated from milk taken from the normal udder under aseptic precautions (47). They have been observed in the milk of a cow in the Cornell University dairy herd for a period of two years and a half, during which time there was no occurrence of udder trouble. This streptococcus when injected into a healthy udder produced mammitis. The excellent record of milk production for several years previous gave assurance that the animal had not suffered a severe attack of streptococcus infection of the udder (47). A number of species have been described as occurring in freshly drawn milk, but the variety of species is very much restricted as compared with those encountered in market milk.

Significance. The presence of bacteria within the udder constitutes an obstacle to the production of absolutely sterile milk. v. Freudenreich collected samples, with aseptic precautions, at the beginning, the middle and the end of the milking, determining the number of bacteria present. The average results of 185 determinations gave for the beginning, 6505 per cc.; for the middle, 1341 per cc.; and for the end, 769 per cc. Kuntze (Ref. 22, Chap. II) obtained an average of 419 per cc. from 40 samples of freshly drawn milk taken at different times during a year. Some very careful American work has shown that the contamination of the whole milking, mostly from within the udder, may vary from 200 per cc. to 900 per cc., depending upon the cow, the average being about 500 per cc. The methods of aseptic production of milk have reached such a point of refinement in some dairies that the bacteria unavoidably introduced from the udder constitute the bulk of the bacteria present in the product when bottled. The occurrence of micrococci and streptococci in milk. in the udder is a circumstance that certainly cannot justly be attributed to carelessness in milk production. Nevertheless, in some cases the contamination from this source has been lessened by avoiding the use 
of cows with leaky teats. Dr. R. G. Freeman has found that such show a higher bacterial coint in the freshly drawn milk (67). The possibility of improvement in this direction is apparently limited, for $\mathrm{v}$. Behring reports that out of a herd of 30 cows, hardly $10 \%$ approach the condition of the theoretically perfect cow, i. e., one having no bacteria in the udder (6).

Foremilk. The very first stream of milk from the teat has been found to contain from 1,000 to 50,000 bacteria per cc. (26). The average of 70 experiments by Conn (10) gives 6,900 per cc. The recognition of the fact that the first streams of milk drawn contain more bacteria than that drawn later suggested the practice of rejecting the first stream or so, to lower the general bacterial content of the milking. A separate vessel is sometimes provided, to avoid the necessity of drawing this foremilk upon the floor of the stall. The whole of the milk contains more or less bacteria and the contamination from the first milk drawn has little effect upon the general average. It has been shown that the rejection of three streams from each teat reduces the bacterial content of the whole milking by 4 per cent., an amount practically negligible (60). The rejection of the foremilk is practiced much more generally than is necessary, for there are few dairies indeed where the contamination from the foremilk is a noticeable factor as compared with that from other sources. This detail is a survival of the time when it was universally believed that the contamination in milk as drawn was derived from the orifice of the teat.

Coat of animal. The excrement and mud adhering to the hair of the cow constitute a most abundant source of contamination. The amount of filth carried by the animal is greatly influenced by the condition of the barn-yard, varying, with the season. Accumulations of manure to which the cows have access, aggravate conditions. Poor location of barns with respect to drainage sometimes creates conditions that cannot even be alleviated by the use of gravel and stone. Instances of the paving of the barn-yard with stone and with cement are known. Currying and brushing the cows is effective, and should be completed at least half an hour before milking is begun. Such a period of time permits the bacteria-laden dust to settle to the 
floor, if the stable be free from draughts. Brushing just before milking will usually double the number of bacteria that would otherwise have gained entrance during milking (60). In the best dairies the switch of the tail is washed before the milking. Precautions are taken to prevent switching, by the use of a tail holder (Ref. 8, Chap. IX).

Exterior of udder. The udder and teats are especially exposed to filth, either from the barn-yard or the stable floor when the cow is lying down. The movements of the udder, during milking, tend to constantly dislodge dust and hair which fall into the milk pail. Dairy practice should include the washing of the udder and teats before milking, when filth is present, and the dampening of the hair whether dirt is present or not. If the udder is left dripping wet, the dirty water will become a source of contamination of the milk. The dampening causes the dust to adhere to the hair and largely eliminates an important contaminating influence. If the hair of the udder is kept clipped short, the cleaning is greatly facilitated. The value of dampening the udder may be demonstrated by a simple bacteriological experiment. Sterile Petri dishes, containing a suitable solid culture medium, may be exposed under the udder for half a minute during milking before and after dampening. After the lapse of time sufficient to permit bacterial growth, the number of colonies of bacteria showing on the two plates will exhibit a wide difference in the number present in favor of dampening (51). The number of bacteria shaken from apparently clean udders may be reduced by two-thirds, by merely dampening. The possibilities of contamination, from really dirty udders, are enormous. By dampening the udder and flanks the contamination may be reduced to about ten per cent. of that which would otherwise have occurred (60).

In the certified dairies maintaining the greatest aseptic precautions, the methods of cleansing the udder are very carefully considered. Practice varies, but the following method will suffice to illustrate the point: Wipe udder and adjoining parts with burlap to remove particles of bedding, wash with lukewarm water applied with a cloth, spray with lukewarm water, wipe with a freshly laundered bath towel. This is so folded 
that one towel may be used on four cows, a fresh surface being used on each udder.

After cows have been cleaned before milking it is desirable to prevent their lying down and becoming soiled. A cow kneels on the fore legs before lying down, and a light chain passed under the throat and affixed to the stanchion will prevent her doing so.

Shape of milk pail. Bacteriological examinations of the foregoing nature have suggested modifications in the shape of the milk pail to minimize the contamination. The changes have been along the line of reducing the area of the opening down to the minimum size that may be used without seriously inconveniencing the milker. Fig. 2 shows a desirable type of milk pail. When the pail is in use, the hood is kept uppermost, 'and since a pail is held at an angle to the floor, between the milker's knees, the hood prevents the vertical exposure of the opening. Covered pails with an aperture, containing a cheesecloth or a wire gauze strainer, are inferior to the pail with the small open area protected by a hood. Such a pail offers a greater area open to contamination, and the strainer does not constitute a barrier to the entrance of bacteria. Nevertheless the covered pail with cheesecloth strainer is very convenient for the milker and is a great improvement over the common open pail. Such a pail will

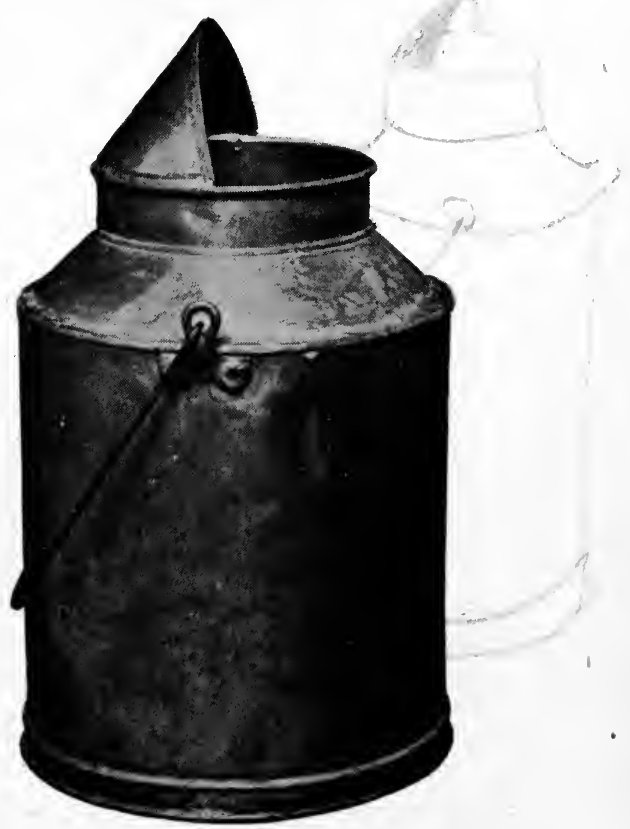

Fig. 2. Pearson's milk pail (Orig.). exclude 29 per cent. of the total bacteria and 41 per cent. of lactic acid organisms as compared with the ordinary open pail in a cleanly dairy. In an extremely dirty dairy the same pail 
(with strainer) will exclude as high as $97 \%$ of the bacteria that fall into the common open pail (59). A strainer of absorbent cotton apparently enmeshes some bacteria and keeps them from the milk. Tests of the Gurler pail have shown that the use of cotton reduces the bacterial count to $30 \%$ of that obtained when the pail is used without the strainer (61).

The milker. The milker is the most important factor in the production of clean milk. Success or failure depends upon his training and faithfulness in carrying out details, the significance of which he may not appreciate nor respect. Milkers, with the exception of a very few in model dairies, trained by bacteriologists, exhibit a low degree of cleanliness in their work. The results obtained by different men, working under the same rules for asepsis, are striking. A group of five students in the Connecticut Agricultural College, trained in the theory of dairy bacteriology, were able to draw milk with one-third the bacterial content of that drawn by the two regular milkers. A well trained college graduate, in charge of the dairy herd, was able to obtain results seven times as good as those obtained by the same two milkers (60). The practice of wetting the hands with milk, which afterwards drips from the teat into the pail, is far from uncommon. It is usually not the practice even to wash the hands before milking. The practice of providing clean overalls for the milkers should be more general. In some certified dairies the milker wears a freshly sterilized suit at each milking period, washes his hands after milking each cow, and uses a sterilized milking stool. The milker as a factor in the contamination of milk with the germs of the infectious diseases of man, will receive consideration in Chap. III.

Milking machines. The advent of the milking machine has been welcomed by some, with the idea that its use would practically eliminate the sources of bacterial contamination within the stable. Hopes in this direction have not been entirely realized. The machine necessitates bringing milk into contact with rubber tubes, which have long been recognized as objectionable. Rubber is very difficult to cleanse thoroughly, in a bacteriological sense, and it is certain that the care given 
by the average dairyman will not satisfy requirements. The complexity of the apparatus and the work involved in taking the machine apart twice a day for cleaning and scalding, afford an excuse for doing it but once a day, a practice which cannot be too strongly condemned. Harrison has compared hand milking with one of the earlier types of milking machine with the result that the machine drawn milk was found to contain from three to twenty times the number of bacteria found in hand drawn milk (28). Stocking (62) has shown the infer-. iority of machine drawn milk with the ordinary care given machines. He paid particular attention to methods of cleaning the rubber tubes, and by the exercise of elaborate precautions, was able to produce results favorable to the machine. The experiments show the possibility that the milking machine, in the hands of an exceptionally careful dairyman, may decrease the pollution of milk. Erf (20) made similar experiments with the care of the rubber parts and in comparative tests of the keeping quality was able to show results in favor of the machine. Tests of milking machines usually have been concerned chiefly with methods of caring for the rubber tubes used with the machines. It has been found necessary to keep the tubes in an antiseptic solution when not in use. Among the substances that are permissible are brine, $3 \%$ formalin solution or lime water prepared with an excess of fresh unslacked lime (30). After use the tubes are rinsed in cold water, then with hot water, and then immersed in the solution. If air remains in any portion of the tubes, bacteria will multiply at that point. Before use on the cow, the tubes must be thoroughly rinsed with hot water to remove the antiseptic. If formalin is used as an antiseptic there is always the possibility that it will not be rinsed out thoroughly, - either through carelessness or intention. On this account the use of this common milk preservative should be interdicted. The use of the milking machine ought to lessen the danger from the contamination of milk by the germs of infectious diseases of man, for it eliminates one of the stages in milk handling during which persons come in close contact with the milk. Nevertheless, there are many other sources for possible infection of milk from diseased per- 
sons. The milking machine increases rather than lessens the possibility of ordinary contamination, and, so long as rubber is used in its construction, $\cdot$ it cannot be regarded as a simple means for avoiding contamination.

Stable. The construction of the building and its condition as regards cleanliness are important factors in milk production. The desirable sanitary features in a stable are those contributing to easy cleaning, freedom from dust, good ventilation and abundant lighting. A one-story structure obviates the undesirable features of the ordinary dusty ceiling with hay

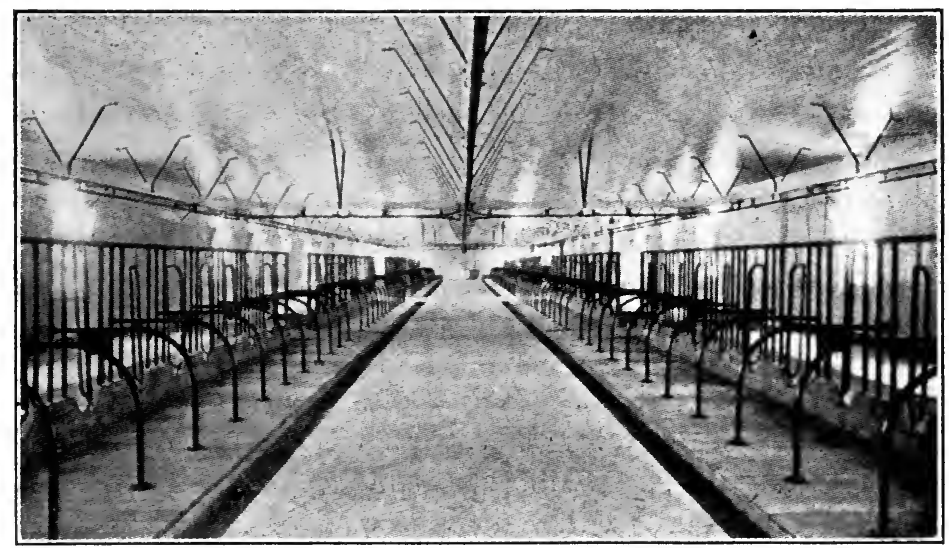

Fig. 3, A convenient stable.

loft above, and, further, usually contributes to better ventilation. Conditions permitting draughts of air, which stir up dust, are to be avoided: Fig. 3 shows a convenient stable. Note the suspended railway track, by means of which the manure is removed in 'buckets to a wagon. The railway is used in a similar way to bring in feed.

Floor. Cement is vastly preferable to wood as a floor, for it cannot become saturated with filth to give rise to offensive odors. By accurate construction of the gutter behind the cows, drainage conditions may be made perfect. A rough sandpaper finish obviates the danger of cows slipping. Planer shavings (17), as bedding, offer the minimum of possibility 
of bacterial contamination, but the use of this material must of necessity be restricted to a very few of the best dairies.

Mangers and stanchions. Wooden mangers, when old, become harboring places for decomposing feed, especially if individual compartments are provided for each cow. Ease of cleaning has resulted in the general use of one continuous cement trough for the whole row of cows. Separate cement mangers, if the cows are habituated to taking certain places, would have a slight tendency to restrain the spread of bovine tuberculosis. In the best stables, wooden stanchions' have been supplanted by a variety of iron devices. The stanchions should be spaced from three to three and one-half feet from center to center; at the least, in order to give room between cows. The swing stanchion is preferable, because it restricts movement forward and backward and thus contributes to the cleanliness of the cow (65).

Barn improvements. The general use of the model dairy barn in milk production cannot be brought about immediately: Therefore at present we have the problem of adapting the older inferior structures to the requirements of clean milk production. Fortunately, with slight structural changes and the exercise of care, milk of 'a very satisfactory sanitary quality may be produced in such barns. The condition of the ordinary wooden floor may be greatly improved by the use of land plaster or sawdust as an absorbent of liquids. Changes for improving the lighting and ventilation are usually possible. 'Ventilation, most important in cold climates where cattle are sheltered in the stable, becomes a negligible factor in mild climates where the cattle are kept indoors only during milking. The accumulation of manure near the building may be avoided by keeping a wagon convenient for loading directly from the stable. At certain seasons the manure may be carted directly to the fields, and, at other times, to a satisfactory distance from the barn. Whitewashing is one of the most popular measures for improving interior conditions. Its occasional åpplication with a brush removes, for the time being, much dust and cobwebs, besides improving the lighting. It is fairly efficient for disinfecting purposes, some other agents being more active. 
Feeding. The dust in the air occasioned by the feeding of grain and hay, during the milking, increases the bacterial content of the milk drawn during the feeding by about one-third of that of cows milked when not feeding, other conditions being alike. The feeding of dry corn stover, immediately before milking, also increases the contamination to about threefold of that occurring without such source of dust in the air (60).

Feeding hay during the milking period is a common practice by no means necessary. Cows accustomed to at least eating grain at that time require considerable training before they will patiently wait until after milking for their feed. Delay in feeding in some cases undoubtedly adds some extra trouble to the attendants, but is practiced in the best dairies.

Certain feeds are highly objectionable because of their effect upon the cow. Brewers' grains, distillers' grains, and sugarbeet pulp are a cheap source of feed in certain localities, and they are fed in great quantity long after attaining an advanced stage of fermentation. The result is a chronic diarrhea in the cows and conditions in the stable that prevent the drawing of clean milk. It is not at all unlikely that milk from cows almost exclusively fed on such highly fermented food, would contain substances not found in the milk of cows consuming wholesome feed. On the other hand, the use of limited quantities of beet pulp and the like, when fresh and combined with a properly balanced ration, seems to cause no trouble. These products, when dried, are unobjectionable (37).

Special milking rooms. Efforts to reduce bacterial contamination to the minimum have, in some dairies, led to the construction of a milking room apart from the general stable where better aseptic conditions might be maintained. Such construction as to permit sterilization of the walls, floor and ceiling, together with the absence of the contaminating features of feeding and manure, offered hope of reducing bacterial contamination. Such rooms are necessarily small and a few cows at a time are admitted. Results have been disappointing, for the movements of the cattle dislodge the dust from the hair and result in a higher bacterial content of the air than in the general stable where the cattle stand quietly. An open shed in a pas- 
ture offers the best conditions for milking, as regards the contamination from air.

Cleansing of utensils. The proper care of the vessels with which milk comes in contact is an important factor in reducing contamination. No precaution for producing good milk is more easily carried out, yet none is more generally neglected. Rinsing in cold or lukewarm water is necessary first to remove the milk. If hot water is used at first it will render cleaning difficult by causing some of the milk constituents to adhere to the utensils. This preliminary step is followed by scrubbing with hot water containing soap powder or some alkali $(16,58)$, and this in turn by rinsing in hot water. The practice of merely rinsing utensils without washing and scalding, after the night's milking, and then using them the next morning, is intolerable.

Scalding. Too often, the final rinsing in hot water is considered sufficient. Bacteriological requirements, however, demand the more thorough application of heat. Harrison (28) and Russell (50) have shown the inefficiency of the ordinary haphazard scalding. To insure complete destruction of all bacteria, - that is, sterilization,- - requires that the utensils be subjected to steam under pressure of at least five pounds for twenty minutes. Fig. 4 shows the apparatus used for this purpose, containing a car used for milk bottles. This method of heating utensils is the only one that may properly be designated as sterilization. The others do not sterilize, as they do not result in the death of all the spores of bacteria. Very excellent results may be obtained by subjecting the utensils to the action of steam in a closed chamber, but not under pressure. La Grange (38) tested the effectiveness of such a piece of apparatus, finding that $99.2 \%$ of all bacteria in milk bottles were killed. Those surviving were spore-bearing organisms. To obtain this result the steam was admitted to the room for fifty-five minutes, about half of this period having elapsed before the temperature reached the boiling point. It is the more common practice to scald utensils over a jet of steam, one by one. La Grange used steam from a half-inch pipe, under a pressure of thirty pounds, and with a duration of fifteen seconds obtained resuits as satisfac- 
tory as by the other method tested by him. When the operator is in a hurry, and shortens the exposure down to three seconds, the efficiency of the method is open to question. The machine in which bottles, in an inverted position, are passed

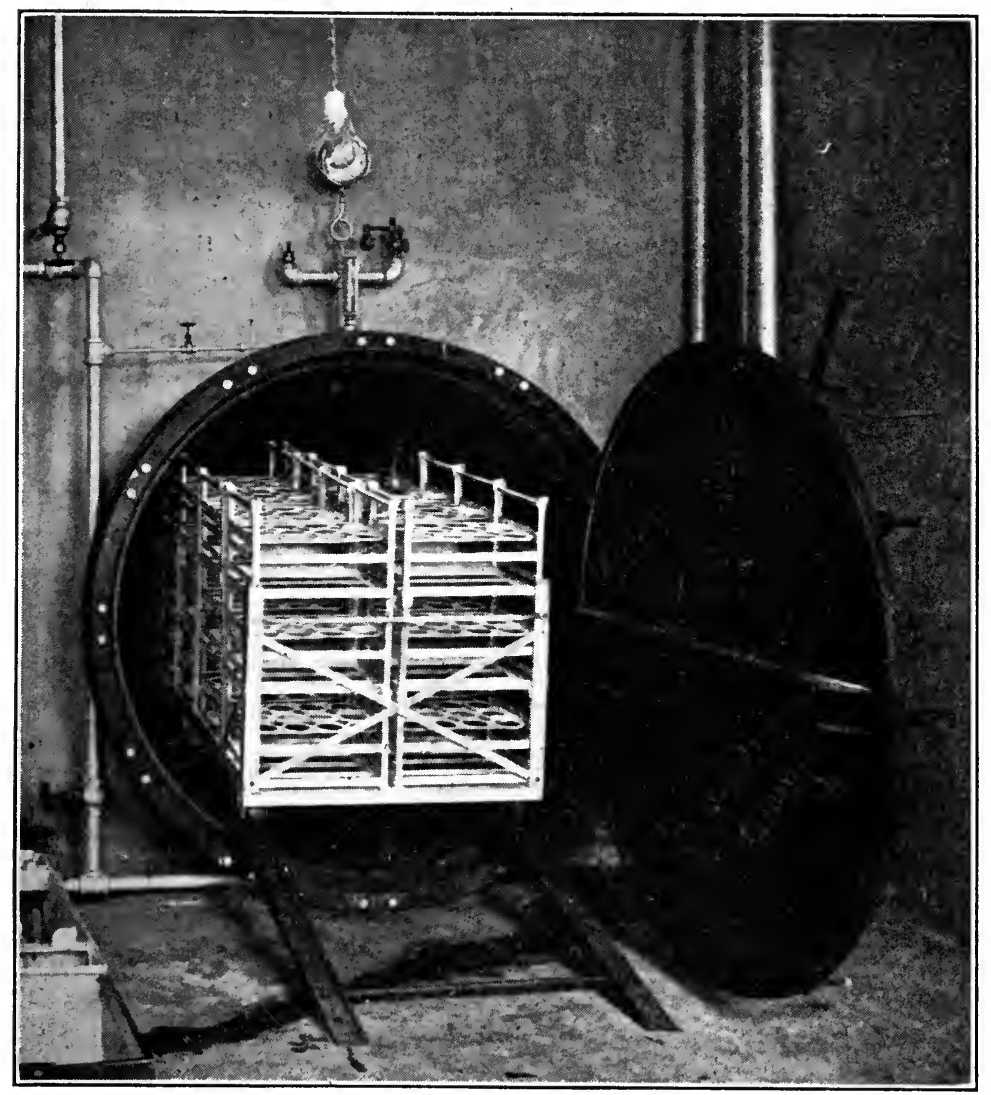

Fig. t. Sterilizer containing racks for holding bottles.

over steam jets, likewise does poor work, unless its speed is so slackened as to reduce its rated output (54). Boiler scale compounds, or oil in the feed water, may so taint the steam that an objectionable odor will be transmitted to the cans or bottles and thence to the milk or cream. 
Boiling water must of necessity be used by the smaller producers. If it is provided in sufficient amount and used with a recognition of the fact that time of exposure, as well as temperature, is a factor in killing bacteria; excellent results may be obtained. A large caldron should be provided in which such articles as strainers and coolers could be immersed for several minutes. Cans should be filled with boiling water and allowed to stand for some minutes before being emptied. 'After scalding and draining, utensils should be kept in a place protected from contamination by dirt.

The cooler permanently installed, and too large to place in a sterilizer, is scalded properly with great difficulty: The use of streaming stean, applied with a hose, is a tedions process, which invites carelessness on the part of the nian doing the work.

Construction of utensils. Cracks or seams of utensils and rust spots afford points for the lodgment of milk, which accumulates in spite of washing, and contributes to contamination. Seamless pails are preferable, but if joints are present they should be flushed with solder. Metallic strainers are the worst offenders in this respect. Valves are a necessary evil, as constant vigilance is necessary to keep them clean. Pipe offers exceptional difficulties in the way of cleaning and scalding, while rubber hose is even worse. The use of wood anywhere that milk will come in contact with it, is very undesirable, on account of the impossibility of cleansing it properly. Wooden plugs for milk cans are still used in New England in spite of their unsanitary qualities.

Handling milk. Immediately after drawing, milk is strained and passed over a piece of apparatus for the purpose of cooling and aerating. Uncleanliness of the apparatus or its location in dusty air, offer opportunities for contamination. Straining through cotton cloth does not remove bacteria $(12,14)$; on the contrary, it may add them if the apparatus is not sterile. Absorbent cotton, between layers of cheesecloth, is the most satisfactory medium for removing visible filth from milk. Clean cheesecloth alone is preferable to the wire'strainer in its usual dirty condition. Milk coolers practically all work on the principle of bringing milk in contact with surfaces 
cooled by water. There may be a water leak in the apparatus, causing contamination from that source. Milk cans are frequently stood in tanks of water, for cooling, and splashing may cause water to reach the milk. The practice of adulterating milk with water is common enough to deserve note as a source of contamination. Bergey (8) has given figures showing the increase in the bacteria of milk at different stages in handling, derived from various utensils.

Bottling milk. The filling of milk bottles in the larger dairies is done rapidly by the use of a bottling machine. In some cases a machine is used which also places the paper caps in position. This is desirable, from a hygienic point of view, because it eliminates the dangers associated with the handling of the paper caps when this is done by a man. When the machine is used, the caps are sterilized before using. When bottles are capped by hand danger from contamination by the workman may be minimized by the use of a special copper tube with a slit on two sides. The caps are stacked in this tube when sterilized, after which they are removed and used by touching the edges only (Ref. 8, Chap. IX).

Milk room. The cooling and subsequent manipulation of the milk should be carried on under conditions as free as possible from the influence of dusty air. A room or building separate from the stable should be provided for the purpose. A cement floor, screened windows and ease of cleaning are desirable features of such a structure. In the best dairies admittance to the milk room is denied to the milker and even visitors. Elaborate precautions are taken to prevent contamination of the milk during straining, etc., even the air being freed from bacteria before entering the room through the ventilating system.

Delivery of milk. Bacteriological considerations lead to the conclusion that delivery in sterile bottles, filled at the dairy, offers the least possibility of contamination in transit. But the milk bottles must be cleaned and heated well before use, if for no other reason than the fact that milk bottles are put to disgusting uses in some households. Bottled milk is not always what it should be, as for instance when the driver fills a dirty 
bottle on the wagon to satisfy a customer's demand for " bottled milk." Dipping or pouring from delivery cans multiplies the possibilities for the entrance of bacteria.

Paper bottles used but once would avoid some of the dangers attributable to the use of glass bottles (57). They have been before the public for some time, but apparently their disadvantages outweigh the advantages, for they have not come into general use.

Milk flavors. Care must be exercised in the production of milk to avoid certain undesirable flavors in the product. Garlic, onion, turnip, when fed before milking, will taint the milk. Experiments have shown that the feeding of anise, fennel and garlic, taints the milk through the excretion of the flavoring substances by the udder (19). Similar considerations point to the necessity of care in the administration of drugs to milch cows, for fear of transmitting the drug to the milk. Backhaus (3) regards the influence of food on the flavor and wholesomeness of milk, through this channel, as unimportant. Warm milk absorbs odors from stable air more quickly than cold milk. It has been shown that exposure from one-half hour to an hour and a half at $57^{\circ}-72^{\circ} \mathrm{F}$. to the odor of either corn silage, horse manure, oils of cinnamon, wintergreen or peppermint, will impart the characteristic odor to milk (52). Fresh urine also imparts an odor, absorbed from the air. Particles of manure by dissolving in the milk impart a flavor. The flavors from silage and alfalfa are not at all offensive, and milk consumers become accustomed to them. The process of aerating milk remedies such defects (39). Aeration is not necessary when milk is drawn under the very best conditions.

Sediments. The deposit in milk, consisting of mud, feces, hair, etc., all too common in milk as delivered to the customer, bears witness to the carelessness in milking $(35,36)$. Straining removes much of the coarse material, but it is frequently found necessary to resort to a more effective process. The milk is run through a cream separator for the purpose of removing the foreign matter by the action of centrifugal force. It is effective, so far as dirt, etc., is concerned, but not in the case of the bacteria, which largely remain in the milk (43). 
In fact, passing milk through a centrifugal machine increases the apparent number of bacteria by separating the clumps ( 55 , 56).

\section{REFERENCES.}

1. Anderson. The cow and her stable. Bul. No. 207, Agr. Exp. Sta. Univ. of Cal., Berkelev, Cal., 1908.

2. Backhaus und Appei. Ueber aseptische Milclgewinnung. II, Ber. Landw. Inst. Univ. Königsb, V, 1898-1899, S. 73.

3. Backhaus. Einfluss des Futters und der Individualität der Milchkuh auf Geschmack und Bekömmlichkeit der Milch. Ber. Landw. Inst. Univ. Königsb., V, 1898-1899, S. 110.

4. Backhaus und Appei. Ueber aseptische Milchgewinnung. Ber. Landzo. Inst. Lniv. Königsb., 1903.

5. BARTHEL. Recherches sur les microorganismes de l'air des étables, du lait au moment de la traite et de la mamelle. Reá. Gén. Lait, $1^{\text {re }}$ Année, 1902, No. 23, p. 529.

6. BEHRING. Suppression of tuberculosis in cattle and the hygienic production of milk. Paper read at the XXXIV Plenary Mleeting of the German Agricultural Council.

7. Bercher. Clean milk. New York: The Hardy Publishing Co., 1903.

8. BERGEY. Sanitary supervision of the collection and marketing of milk. Univ. of Penn. Med. Bul., July-August, 1904.

9. Burr. The source of acid organisms of milk and cream. Centbl. Bakt., etc., 2 Abt., Bd. VIII, 1902, No. 8, S. 236.

10. Conv. Bacteria in freshly drawn milk. Fifteenth Ann. Rept. Storrs Agr. Exp. Sta., Storrs, Conn., 1903, p. 92.

11. Conn, Esten and Stocking. Classification of dairy bacteria. Eighteenth Ann. Rept. Storrs Agr. Exp. Sta., Storrs, Conn., 1906, p. 91.

12. Conn and Stocking. Comparison of bacteria in strained and unstrained samples of milk. Fifteenth Ann. Rept. Storrs Agr. Exp. Sta., Storrs, Conn., 1903, p. 33.

13. Conn and Stocking. Aseptic milk. Fifteenth Ann. Rept. Storrs Agr. Exp. Sta., Storrs, Conn., 1903, p. 52.

14. Conn and STocking. Strained and unstrained milk preserved at $70^{\circ}$ and $50^{\circ}$. Fifteenth Ann. Rept. Storrs Agr. Exp. Sta., Storrs, Conn., 1903, p. 38. 
15. Dairy Division, Bureau of Animar, Industry. Suggestions for construction of a modern dairy barn. Cir. No.90, Bur. Anim. Ind., U. S. Dept. Agr., Washington, D. C., 1906.

16. DOANE. The disinfectant properties of washing powders. Bul. No. 79, Maryland Agr. Exp. Sta., College Park, Md., 1902.

17. DoAns \%. Tests of materials for bedding cows. Bul. No. 104, Maryland Agr. Exp. Sta., College Park, Md., 1905.

18. D'HeIl. Zeitschr. Fleisch u. Milchhyg., 1905, S. 84 ; also, Jour. of Compar. Path. and Ther., Vol XIX, 1906, p. 50.

19. Drombrowski. Some experiments on the passage of odoriferous and coloring substances into milk. Arch. Hyg., Vol. L, 1904, No. 2, p. 183. Abstract in Exp. Sta. Rec., Vol. XVI, No. 1, p. 191.

20. ERF. Milking machines. Bul. No. 140, Kansas State Agr. Col. Exp. Sta., Manhattan, Kan., 1906.

21. Ford. The bacteriology of healthy organs. Trans. Assoc. Amer. Phys., Vol. XV, 1900, p. 389.

22. Fraser. Preventing contamination of milk. Bul. No.91, Cniv. of Ill. Agr. Exp. Sta., Urbana, I11., 1903.

23. Fraser. City milk supply. Bul. No. 92, Univ. of Ill. Agr. Exp. Sta., Urbana, Ill., 1903.

24. Fraser. Effect of corn silage on the flavor of milk. Bul. No. 101, Uniz. of Ill. Agr. Exp. Sta., Urbana, I11., p. 644.

25. FreUdenREICH. Ueber das Vorkommen von Bakterien im Kuheuter. Centbl. Bakt., etc., 2 Abt., Bd. X., 1903, No. 13, S. 401.

26. FREUDENREICH. Ueber die Bakterien im Kuheuter und ihre Verteilung in den verschiedenen Partien des Melkens. Landw. Jahrb. Schweiz., 1904.

27. FREUDENREICH und'THÖNI. Über die in der normalen Milch vorkommenden Bakterien und ihre Beziehungen zu dem Käsereifungsprozesse. Landw. Jahrb. Schweiz., 1903.

28. HARRISON. The bacterial contamination of milk and its control. Trans. Canad. Inst., Vol. VII., 1902-1903, p. 467.

29. HARRISON and CUMming. The bacterial flora of freshly drawn milk. Jour. Appl. Micro. and Lab. Methods, Vol. V, No. 11, p. 2029.

30. HASTINGS and HoFFMANN. Bacterial content of machine-drawn and hand-drawn milk. Twenty-fourth Ann. Rept. Agr. Exp. Sta. Univ. Wis., Madison, Wis., p. 213.

31. Henderson. A contribution to the study of mastitis in cows. Jour. of Comp. Path. and Ther., Vol. XVII, 1904, p. 24.

32. HENDERSON. The relationship of the bacteriological condition of the udder to the health of the community. Jour. Sanitary Institute, Vol. 25, 1904, p. 563. 
33. HOPPER. Suggestions for the improvement of dairy barns. Cir. No. 95, Agr. Exp. Sta. L'niv. Ill., Urbana, I11., 1905.

34. Hunziker. The care and handling of milk. Bul. No. 203, Cornell Univ. Agr. Exp. Sta., Ithaca, N. Y., 1902.

35. Kober. Milk in relation to public liealth. Senate Document No. 471, 57th Congress, 1st Session, Washington, D. C., 1902.

36. KOBER. Milk sedinents or dirty milk in relation to disease. Cir. 114, Bur. Anim. Ind., L. S. Dept. Agr., Washington, D C., p. 18.

37. LiNDSEy. Distillery and brewery by-products. Bul. No. 97 , Hatch Exp. Sta. Mass. Agr. Col., Amherst, Mass., 1904.

38. LA GRANGE. A compatison of methods of scalding milk cans by steam. Thesis for the degree of Bachelor of Science, Lniz'. Cal., Berkeley, Cal., 1906.

39. MARSHALL. The äeration of milk. Contributions to Medical Research, dedicated to Victor C. Vaughan, p. 237. Ann Arbor, Mich.: George Wahr, 1903.

40. MARSHAIL. The discussion of the milk problem from the standpoint of production. Bul. No. 228, Mich. State Agr. Col. Exp. Sta., Agricultural College, Mich., 1905.

41. Moore. Preliminary investigations concerning the number and nature of bacteria in freshly drawn milk. Tuelfth and Thirteenth Ann. Rept. Bur. Anim. Ind., C. S. Dept. Agr., Washington, D. C., p. 261.

42. Mooke. The normal bacterial invasion of the cow's udder. Proceedings of the Society for the Promotion of Agricultural Science, 1899.

43. MOORE. Inefficiency of milk separators in removing bacteria. Yearbook, U. S. Dept. Agr., Washington, D. C., 1895, p. 431.

44. MOORE and WARD. An inquiry concerning the source of gas and taint producing bacteria in cheese curd. Bul. No. 158, Cornell Univ. Agr. Exp. Sta., Ithaca, N. Y., 1899.

45. Peanson, R. A. Facts about milk. Farmers'Bul. No. 42, U. S. Dept. Agr., Washington, D. C., 1906.

46. Pearson, R. A. Care of milk on the farm. Farmers' Bul. No. 63, U. S. Dept. Agr., Washington, D. C., 1897.

47. REED and WARD. The significance of the presence of streptococci in market milk. Amer. Med., Vol V, 1903, No. 7, p. 256.

48. REYNor,Ds. Milk as affected by stable practices and subsequent handling. Proc. Amer. Vet. Med. Assoc., 1907, p. 338.

49. RoBy. The economic production and distribution of clean milk. Jour. Amer. Med. Assoc., Vol. 46, 1906, p. 1430.

50. Russei.L. Outlines of dairy bacteriology. Madison, Wisconsin: H. L. Russell. 
51. RuSSELI. The sources of bacterial infection and the relation of the same to the keeping quality of milk. Eleventh Ann. Rept. Agr. Exp. Sta. Uniz. of Wis., Madison, Wis., 1894, p. 150.

52. RusSELI. Relative absorption of odors in warm and cold milk. Twentieth Ann. Rept. Agr. Exp. Sta. Univ. of Wis., Madison, Wis., 1903, p. 236.

53. RUSSELI, and HASTINGS. Disappearance of bacteria artificially introrluced into cows' udders. Twenty-first Ann. Rept. Agr. Exp. Sta. Univ. of Wis., Madison, Wis., 1904, p. 164.

54. RUSSELI, and HoFFMANn. Bacteriological test of a bottle-washing device. Twenty-second Ann. Rept. Agr. Exp. Sta. Univ. of Wis., Madison, Wis., 1905, p. 227.

55. SeVERIN. Vermindert die Zentrifugierung die Bakterienzahl in der Milch? Centbl. Bakt., etc., 2 Abt., Bd. XIV, 1905, S. 605.

56. SEVERIN and BUDINOFF. Contribution to the bacteriology of milk. Centbl. Bakt., etc., 2 Abt., Bd. 14, 1905, s. 463.

57. STEWART. The single service milk bottle; its advantages and adaptability for general use. Sanitation, December, 1904.

58. STEWART. Cleansing of milk vessels : relative value of washing powders. Amer. Med., Vol. XI, 1906, No. 7, p. 241.

59. STocking. Efficiency of a covered pail in excluding filth and bacteria from milk. Fourteenth Ann. Rept. Storrs Agr. Exp. Sta., Storrs, Conn., 1901, p. 105.

60. STocking. Quality of milk as affected by common dairy practices. Eighteenth Ann. Rept. Storrs Agr. Exp. Sta., Storrs, Conn., 1906 , p. 66.

61. STocking. Comparative studies with covered milk pails. Bul. No. 48, Storrs Agr. Exp. Sta., Storrs, Conn., 1907.

62. STocking. Bacteriological studies of a milking machine. Bul. No. 92, Bur. Anim. Ind., U. S. Dept. Agr., Waslington, D. C., 1907.

63. Stocking and Mason. Milking machines. Effect upon quality of milk. Bul. No. 47, Storrs Agr. Exp. Sta., Storrs, Con11., May, 1907.

64. Swithinbank and Newman. The bacteriology of milk. London: J. Murray, 1903.

65. Trueman. Improving dairy conditions. Bul. No. 53, Storrs Agr. Exp. Sta., Storrs, Conn., 1908.

66. WARD. The persistence of bacteria in the milk ducts of the cow's udder. Jour. Appl. Micros. and Lab. Methods, Vol. I, No. 12, 1898, p. 205.

67. WARD. The invasion of the udder by bacteria. Bul. No. 178, Cornell Univ. Agr. Exp. Sta., Ithaca, N. Y., 1900. 
68. WiLlem et MiNNE. La traite peut-elle fournir du lait aseptique? Rev. Gén. Lait, 4 Année, 1904, No. 6, p. 121.

69. Willem et Mifin. Essais de traite aseptique. Rez. Gén. Lait, $4^{\text {e }}$ Année, 1905, No. 18, p. 409.

70. Willoughby. Milk, its production and uses. London: Charles Griffin \& Company, Ltd., 1903.

71. Winsıow. The production 'and handling of clean milk. New York: Wm. R. Jenkins Co. 
CHAPTER II.

\section{CHANGES IN MILK CAUSED BY BACTERIA.}

Significance of bacterial contamination. The mere consideration of the multiple sources of contamination of milk, emphasizes the truth of the statement that freshly drawn milk contains a wide variety of bacterial forms. Certainly no food used so universally by man is exposed during its preparation to a greater variety of contaminating influences. The significance of these bacteria in the subsequent changes in milk depends upon their character, adaptability for existence in milk, and upon the conditions under which milk is kept. The precautions exercised in restricting the growth of bacteria are of greater importance in controlling the character of the milk when consumed, than those exercised to prevent the initial contamination. The results of changes of bacterial origin in milk, concern not merely the commercial requirements that it must be unaltered in taste and appearance when consumed, but also have a direct bearing upon the hygiene of food.

The constituents of milk and the form in which they exist, together with the temperatures to which milk is exposed, offer conditions favorable to the growth of quite a variety of bacterial groups. The carbohydrates represented by the milk sugar are present in solution, a most favorable form for bacterial nutrition. The albuminous constituents, either in solution or in a finely divided state in suspension, are likewise freely available to satisfy bacterial requirements.

Fat alone, of the constituents of milk, resists the action of the common bacteria found in milk. When consideration is paid to the rapidity of the growth of bacteria, and to the fact that decomposition of organic matter is the chief function of bacteria as a class, the full significance of the vulnerability of milk becomes apparent.

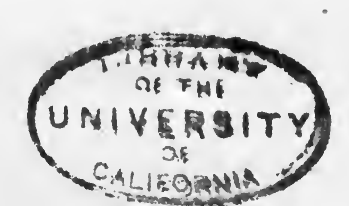


Under favorable conditions of food, temperature, environment, etc., the possibilities of bacterial multiplication are enormous. The temperatures to which milk is exposed in the summer, when not refrigerated, are highly farorable to their multiplication.

Numbers of bacteria in market milk. Hill and Slack (19) have tabulated results of examination of 2,394 samples of milk in Boston, covering a period of four months (June to September), with results as follows :

TABLE, I.

BAC'TERIA IN BOSTON MILK.

Per cent.

Below 100,000 bacteria per cc.

42.

Between 100,000 and 500,000 per cc.

29.75

Between 500,000 and 1,000,000 per cc.

9.75

Between 1,000,000 and 5,000,000 per cc.

12.75

Above 5,000,000 per cc.

5 .

Uncountable plates

These figures are not exceptionally high, but are good as compared with others. Bacterial counts rumning into the millions are common in hot weather. Rosenau (34) found that the milk of Washington, D. C., averaged 22,134,000 bacteria per cc. in 1906 and 11,270,000 per cc. in 1907 during the months of July, August and September. This'writer gives a resumé of results of similar work done elsewhere.

Effect of temperature on bacterial growth. At $1^{\circ} \mathrm{C} .\left(34^{\circ} \mathrm{F}.\right)$ bacterial growth is very powerfully restrained for awhile. Milk, after six or eight days at this temperature, may show less bacteria than when freshly drawn. The circumstance is attributable to the "germicidal" phenomenon of milk. Pennington (32) in the study of samples of milk kept for long periods at $1^{\circ} \mathrm{C}$ : found that certain bacteria multiply at that temperature. In time the numbers may run into the millions per cc. The species belonged to the group of organisms capable of acting on protein, without affecting the appearance of the milk. These observations were made upon the best milk obtainable, as well as upon poor milk. It must be concluded that cold storage cannot be relied upon to keep milk indefinitely. At $10^{\circ} \mathrm{C}$. $\left(50^{\circ} \mathrm{F}\right.$.) milk may be kept for two or three days without an 
increase in numbers, and those growing at that temperature not lactic acid bacteria. At $20^{\circ} \mathrm{C}$. $\left(68^{\circ} \mathrm{F}\right.$.) milk sours in forty hours. At $37^{\circ} \mathrm{C} .\left(99^{\circ} \mathrm{F}\right.$.) curdling occurs in a few hours (11). The length of time required for transportation and delivery of milk is frequently such that refrigeration must be used to insure its reaching the consumer in proper condition.

Methods of cooling. Some of the methods on the farm are crude and inefficient. The process of passing milk through the air to remove undesirable odors-aeration-will accomplish some reduction of temperature. Cans of milk may be stood in a tank of water, and by stirring the milk occasionally the temperature may be reduced. In a hot dry climate cans may be covered with burlap and dampened. The evaporation from the burlap will lower temperature. In the same way, wet blankets over cans on a wagon are of use.

There are various mechanical devices for utilizing cold water. These fail in hot weather, when most needed. The use of ice with proper apparatus is productive of better results, and is esseintial in hot weather. The use of ice constitutes the standard, approved method of cooling milk on the small dairy farm, in climates where natural ice may be obtained.

Mechanical refrigeration, by means of anhydrous ammonia or carbon dioxide, furnishes the most efficient means for preserving milk in large quantities (38). It is employed in city distributing depots, and in the best large dairies. It may, and should, be very widely used in connection with dairies in warm climates.

Milk during transportation. The refrigerator car, with abundant ice supply, solves the problem of shipping milk long distances in tanks. It is not so effective for local traffic, when the car doors are frequently opened.

Bottles of milk in crates may be kept in good condition for quite a time without a refrigerator car, by packing cracked ice about them. Bottles of certified milk, packed in closed wooden boxes, perrhaps metal lined, and thoroughly surrounded with cracked ice, may likewise be shipped. Milk in cans covered with non-conducting jackets of hair may be kept cool longer than otherwise $(4,14,43,44)$. 
Preservation by chemicals. Bacterial changes in milk or cream may be retarded by the addition of various' chemicals, such as borax, formalin, and others. They are substitutes for cleanliness and refrigeration, besides being undesirable constituents of an article of food. Their use in milk has been, and needs to be, very vigorously opposed by pure food laws. The campaign against the use of milk preservatives has been very effective. The result has been an increase in the use of another method for compensating for deficiencies in the care of milk, that is, commercial pasteurization. Budde has suggested a method of preserving milk by the addition of hydrogen peroxide, which is very readily removed from milk by heating. The scheme has not received serious consideration. The matter of the use of preservatives and their detection, is discussed in Chap. XI. The changes in milk constitute a complex biochemic problem, but certain of the more common ones may be discussed in a systematic manner.

Lactic acid fermentation. The souring of milk is the manifestation of the commonest of fermentative changes in milk. As a result of bacterial activities the lactose is transformed into lactic acid, which compound is responsible for the characteristic flavor and curdling of soured milk. A considerable number of bacteria are capable of inducing the change, but it has been shown that a very small group of organisms are ordinarily found in milk when souring is well advanced. In fact, one of these, Bact. lactis acidi, may be regarded as the typical lactic acid organism. It has been found in numerous examinations made of milk from widely separated quarters of the United States. Its identity with the lactic acid organism described by Leichmann in Europe has been established and this fact adds strength to the view that it may be regarded as the common lactic acid organism. This organism has been classified as a rod form (bacterium) because the individual cells are usually longer than broad. It forms chains of greater or less length and in bouillon culture sometimes appears as chains of undoubted micrococci. Streptococcus lacticus Kruse is another widely distributed organism observed to predominate in souring milk. Some writers have insisted 
upon abandoning the use of the name Bact. acidi lactici Leichmann on the ground of the identity of the organism with Streptococcus lacticus Kruse. The discussion illustrates the difficulties of bacterial classification and has certainly emphasized the fact of the common occurrence in milk of streptococci and other forms almost indistinguishable from them. Members of the $B$. lactis aerogenes and B. coli communis (37) groups are capable of causing souring of milk, but require a temperature near that of the animal body in order to flourish and become a factor in the souring process. The fact that one species of lactic acid producing organism may predominate in milk in which the fermentation is well advanced, is surely an evidence that the species in question is best fitted to survive. In the earlier stages of fermentation a greater number of species participate, but gradually succumb in the competition on account of intolerance to acid, other bacterial products, or other environmental conditions. It has been shown that a certain non-acid producing organism, by some means, creates conditions more favorable to Bact. acidi lactici, and contributes to the more rapid souring of milk than would occur without its presence $(25,26)$. The growth of lactic acid organisms in souring milk is not unlimited, for eventually their multiplication is checked by the product of their own growth-lactic acid.

The lactic acid organism owes its pre-eminence in milk to its thorough adaptation to the environment in competition with other organisms. In fresh milk it forms a small percentage of the bacteria present. At $10^{\circ} \mathrm{C}$. $\left(50^{\circ} \mathrm{F}\right.$.) it multiplies slowly, gaining no advantage over competitors, but at $20^{\circ} \mathrm{C}$. $\left(68^{\circ} \mathrm{F}\right.$.) it predominates. At this latter temperature milk is curdled in forty hours.

The lactic acid fermentation is deleterious in the sense that the result of its progress terminates the period during which milk is a salable food product. When milk for domestic purposes sours sooner than usual, the blame is laid upon the dealer. This fermentation produces manifestations in the taste and appearance of the milk easily recognized by the consumer and in the popular mind is an index of the keeping quality of the 
product. Its occurrence naturally furnishes the principal commercial incentive, and almost the only such one that milk dealers have, to exert efforts to improve the quality of milk as regards bacterial content.

The attitude of the buttermakers and cheesemakers towards the lactic acid fermentation is quite the reverse. The formation of lactic acid is as yet a necessary step in the manufacture of both butter and cheese. The maintenance of temperature conditions favoring the fermentation is an important detail in the manufacture of both products.

That sour milk is, or the organisms causing it are, harmful to the average normal adult cannot be maintained. On the contrary, soured dairy products frequently form an article of diet, as for example, buttermilk and plain sour milk. Metchnikoff has laid emphasis upon the value of sour milk as an article of diet (28).

The importance of the lactic acid fermentation has occasioned considerable experimental work to determine the source from which the bacteria commonly gain access to milk. The existence of bacteria within the udder has suggested a study of those organisms with reference to the possible presence of that one among them. They have been isolated a few times from cultures made direct from the glandular tissue of freshly slaughtered animals. Extensive examinations of the bacterial flora of milk drawn with aseptic precautions have shown them in stich few instances that their presence in those particular samples was regarded as an accidental contamination from sources other than the interior of the udder. For instance, in a series of two hundred and five samples, taken from seventy cows during several days, the organism was found in only eight instances (7). Examinations of the stable air and the dust shaken from the animal during milking have shown the constant presence of Bact. acidi lactici. The conclusion follows, that milk is contaminated with the lactic acid organisms while being drawn, and that the interior of the udder is of no importance as a source. The observations made did not include the influence of dirty utensils containing souring milk, which, of course, is a factor, the importance of which is obvious. 
Putrefactive processes. The decomposition changes of the casein and albumen of milk by bacterial action are less noticeable than the decomposition of milk sugar, but more important from a hygienic point of view. Such alteration of nitrogenous compounds is designated putrefaction, and in the process the milk assumes an alkaline reaction. Among the direct products of the bacteria, or decomposition products of nitrogenous compounds produced by them, are some that produce toxic effects in man. The changes under ordinary conditions are not such as to call the attention of the consumer to the condition, as in the case of soured milk.

Organisms causing putrefaction. As in the case of the lactic acid fermentation, a great number of species are capable of inducing putrefaction. The organisms are frequently spore bearers, and when cultivated on gelatin usually cause liquefaction of that medium. The change is induced by enzymes elaborated by the organisms and acting thereafter quite independently of them. This action is illustrated in gelatin by the area of liquefaction surrounding the growth of the organism. In milk the action on the nitrogenous constituents may or may not be preceded by a curdling of the milk by enzyme action. Milk poorly cooled in hot weather will sometimes curdle, showing a weakly acid or alkaline reaction, due to enzyme action. The group of organisms of which Bacillus subtilis is the type is a common representative of the putrefactive organisms.

Antagonism of lactic acid fermentation. The active progress of putrefactive changes does not occur under conditions favoring the souring of milk, for the rapid multiplication of the lactic acid organisms creates conditions unfavorable for putrefaction (5). In this sense, souring may be considered as a beneficent process, protecting milk against a worse decomposition.

Conditions controlling putrefaction. Putrefactive organisms are able to multiply at temperatures somewhat below $20^{\circ} \mathrm{C}$. more rapidly than the lactic acid organisms. Hence, milk kept at low temperatures is more apt to undergo putrefaction than souring. The point should be made that at such tempera- 
tures putrefaction goes on slowly, so that this circumstance is of no practical importance in the care of milk as customarily kept for consumption. A very old milk, however, even though it has been kept at $12^{\circ} \mathrm{C}$. and not sour, may not be free from the products of putrefaction.

Source of putrefactive organisms. The dust of stable air, and particularly the filth dropping into the milk pail from the udder and flanks of the cow, certainly contribute liberally to infection by putrefactive organisms. Poorly cleansed milk utensils and polluted water deserve mention. In fresh milk these organisms greatly outnumber the lactic acid organisms.

Toxic milk. There are on record a few cases of poisoning believed to have been due to the elaboration of toxic substances by bacteria in milk. Very little is known about the topic. Kastle (21) has made a summary of the subject and has collected a bibliography.

Ropy milk. None of the faults of milk arouse the distrust of the consumer more than the viscid condition of milk and cream, popularly designated " ropy.', The widespread abhorrence of milk in this condition is induced by the belief that it is the product of a diseased udder. The false inference is encouraged by the fact that dairymen sometimes refer to the milk of an inflamed udder as "ropy" or "stringy." There is no relation between the two and no real confusion beyond that induced by the double significance of the word ropy. There is no ground for attributing a harmful result from the consumption of the ropy milk delivered to customers, but the occurrence of the trouble menaces the success of a milk route by occasioning loss of custom.

The viscid condition appears not sooner than twelve hours, but sometimes as late as thirty hours, after milking. Furthermore, it is most readily observed in milk that has stood undisturbed for several hours, during which period the cream has risen. These conditions give the false impression that the trouble is only associated with cream, while, in fact, skim milk is just as susceptible to the trouble. The consistency of cream does, however, accentuate the viscosity. Fig. 5 shows the behavior of ropy cream when lifted with a fork. 
Cause of ropy milk. The condition is brought about by the presence of Bacillus lactis viscosus, described first by Adametz (1). The individual bacteria possess enveloping masses of slimy viscid material,

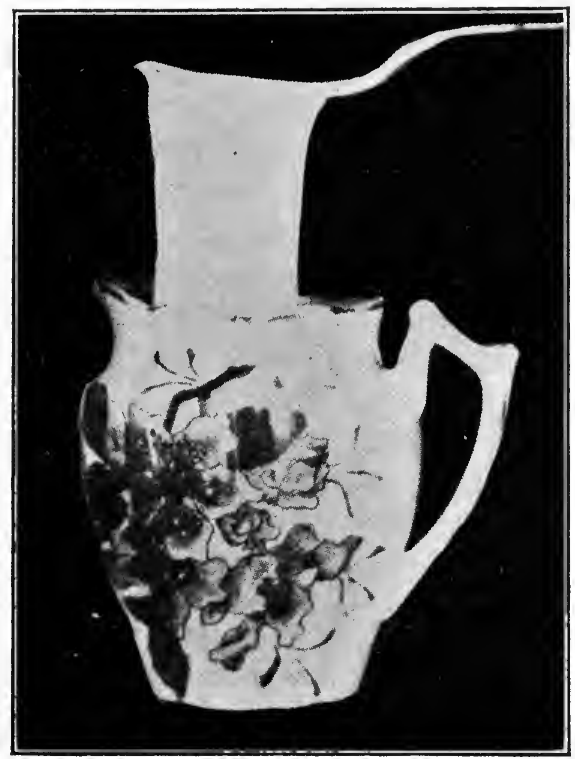
which impart a similar characteristic to the milk when they are present in sufficient $11 \mathrm{umbers}$. Fig. 6 shows the ropy milk organisms. The capsules of viscid substance are represented by white areas surrounding each cell.

Many orgànisms capable of inducing viscosity when grown in milk, under various conditions, have been described. Advances in methods of identifying bacteria make it Fig. 5. Ropy cream lifted with a fork (41). impossible to say how

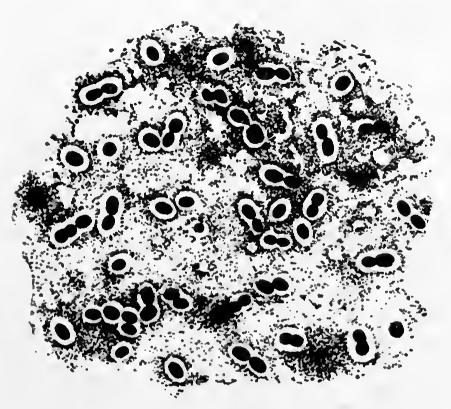

Fig. 6. Bacillus lactis viscosus, from a milk culture (42). many of these organisms are really identical. The more recent studies of the occurrence of ropy milk in dairies in North America and Europe, point to the conclusion that $B$. lactis viscosus is very largely the cause of the trouble. The ropy milk organisms isolated by the writer have always been of this species (42). Harrison has found some different species (16). 
Biological characteristics of B. lactis viscosus. The organism has been isolated from water, which is considered its natural habitat. Growth is fairly luxuriant at $15^{\circ} \mathrm{C}$. $\left(59^{\circ} \mathrm{F}\right.$.), best at $25^{\circ} \mathrm{C} .\left(77^{\circ} \mathrm{F}\right.$. $)$ and very slight at $37^{\circ} \mathrm{C}$. $\left(98^{\circ} \mathrm{F}\right.$. $)$. However, $8^{\circ} \mathrm{C}$. $\left(46^{\circ} \mathrm{F}\right.$.) is not low enough to inhibit growth. The organisms multiply rapidly enough in ice water to induce viscosity in milk kept in cans in ice water: That is, this organism forms an exception to the rule that care in cooling milk inhibits the multiplication of bacteria. At low temperatures the ropy milk organisms have a comparatively clear field for growth, free from serious competition with the lactic acid organisms. At higher temperatures, such is not the case. $B$. lactis viscosus will grow only in the presence of air, which accounts for the appearance of viscosity first on the top of milk. This biological peculiarity is doubtless the reason that ropy milk is never, or rarely, seen in bottled milk. The organism does not form spores, and is killed in culture by exposure to $58^{\circ} \mathrm{C}$. $\left(136^{\circ} \mathrm{F}.\right)$ for ten minutes $(16,41)$.

Sources of contamination of milk. The fact that B. lactis viscosis grows with great difficulty at blood heat, effectually disposes of any suspicion that ropy milk is the result of disease in the cow. Water must be regarded as the original source of trouble, but it may by no means be the immediate one. The cow may, sometimes, carry the organisms on the hairy coat, from water to the milk. Several observers have isolated ropy milk organisms from stable air. When ropy milk is causing trouble, the organisms are found with great frequency in samples taken from the floor dust of milk rooms. The practice of cooling cans of milk nearly immersed in a vat of ice water affords, in the milky water, favorable conditions for the multiplication of the organisms and for the contamination of the milk by them. The spattering of water, incident to moving cans or adding ice, gives opportunity for the contamination of the milk. The corrugated milk cooler, contàining water in circulation, may have a leak, giving opportunity for direct contamination from water. The practice of merely rinsing utensils at night and using them in the morning without scalding, gives another opportunity for bringing water into contact 
with the milk. Unclean utensils constitute the greatest factor in the contamination of milk. The wire mesh strainer, partially clogged with filth, may be the only visible evidence of carelessness. Bacteriological examination of the supposedly clean utensils will reveal the presence of ropy milk organisms in a large percentage of examinations. This is most readily done by pouring separate samples of sterilized milk into the various suspected utensils and then immediately out again. These samples kept at a low temperature for several days will become viscid if they have been in contact with the bacteria of ropy milk. Attention to the technic of washing utensils will reveal the fact that the scalding is not carried out in accorddance with the bacteriological requirements governing the practice. Carelessness in this regard is by no means limited to farmers with poor scalding equipment. It is just as frequently the result of too hasty steaming of cans by employees in large city concerns, who misuse the abundant facilities for scalding at their disposal. Gross neglect, therefore, permits the ropy milk organisms to exist in milk utensils from day to day, to contaminate each succeeding lot of milk. Under such conditions the milk strainer, designed to improve the quality of milk, becomes a potent factor in its deterioration.

Means of combating ropy milk. The control of this milk fault is a comparatively simple matter when bacteriological principles are borne in mind. In most cases the trouble may be abated by instituting the continued practice of a thorough scalding of every utensil with which milk comes in contact. In the absence of steam, immersion in boiling water for three to five minutes will serve the purpose. Milk cans too large for immersion in the vessel at hand may be filled with boiling water and should be left filled for five minutes. As a precaution against dust contamination, pails and cans, after cleaning, should be stood bottom side up. Strainers, coolers, etc., should likewise be protected in some manner. In most cases the dirty wire strainers may be replaced by cheesecloth strainers. The sources of contamination from water are easily remedied. The location of the source from which contamination is derived may be determined by taking samples of milk 
at various stages in the handling, and watching for the appearance of ropiness after the milk has stood a day in a cool place. Frequently it will be found that the milk as it comes from the stable is normal and that the source of contamination is in the milk room. If such is not the case, the dampening of the udders of the cows, before milking, will be necessary $(41,42)$.

Germicidal activity. When samples of freshly drawn milk are examined at frequent intervals for numbers of bacteria, the fact becomes evident that the total numbers do not immediately begin to increase. The numbers may decrease or remain stationary for a period before the increase of bacteria begins. Immediate increase of total numbers is distinctly the exception. The phenomenon varies in degree in the milk of individual cows (20).

Kunze (22) determined the number of bacteria in milk when freshly drawn, after thorough cooling, after sixteen hours at $6-8^{\circ} \mathrm{C}$. and after forty hours at $6-8^{\circ} \mathrm{C}$. He averaged the results of 35 samples collected at periods covering a whole year. The freshly drawn milk was very clean, averaging only about four hundred colonies per cc. Thorough cooling alone reduced the original count by $11.4 \%$. After sixteen hours at $6-8^{\circ} \mathrm{C}$. it was reduced by $16.8 \%$. At forty hours the count was $33.09 \%$ of the original, a reduction of $21.69 \%$ from the count taken just after cooling.

The length of the period of decline, in any case, is governed by the temperature at which the milk is kept. For instance, at $37^{\circ} \mathrm{C}$. $\left(98^{\circ} \mathrm{F}\right.$.) the period lasts about three hours; at $21^{\circ} \mathrm{C}$. $\left(70^{\circ} \mathrm{F}\right.$.), three to twelve hours ; at $13^{\circ} \mathrm{C}$. $\left(55^{\circ} \mathrm{F}\right.$. ), about twentyfour hours; at $4^{\circ} \mathrm{C} .\left(40^{\circ} \mathrm{F}\right.$.), forty-eight hours; at $1^{\circ} \mathrm{C} .\left(34^{\circ} \mathrm{F}\right.$. $)$, six to eight days.

The temperature governs the extent of decrease. At $70^{\circ} \mathrm{F}$. the decrease is marked, frequently $50 \%$ or more in market milk. At $55^{\circ} \mathrm{F}$. it is less marked, and at $40^{\circ} \mathrm{F}$. still less. These observations are presented in a graphic way in Fig. 7. The chart (Fig. 7) shows the changes in the number of bacteria in three portions of the same original sample of milk, kept at different temperatures. The sample was drawn from the cow with the strictest aseptic precautions. 


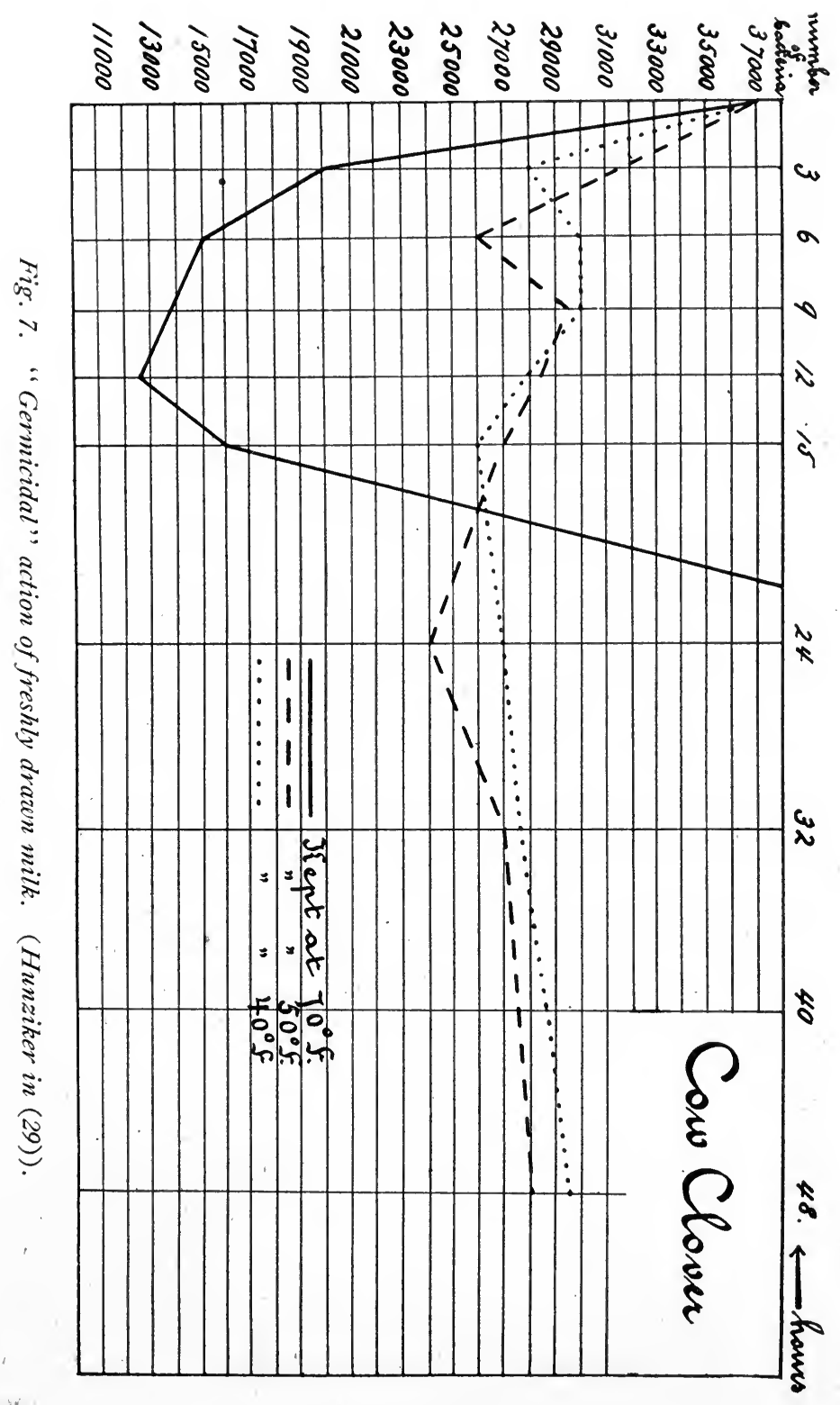


The germicidal action is observed in samples drawn so carefully that none but the micrococci from the interior of the udder are present, as well as in samples of highly contaminated market milk. The fact that the greater decrease in milk containing only udder micrococci occurs at $70^{\circ} \mathrm{F}$, , rather than at $40^{\circ} \mathrm{F}$., is of interest. The explanation has been advanced very recently (22) that these organisms die off in refrigerated milk, because the temperature is so different from that to which they are accustomed. The theory does not harmonize all the facts observed in connection with the phenomenon.

The germicidal action of milk is destroyed by heat, being stopped completely by $176^{\circ} \mathrm{F}$. for forty minutes. Milk heated to the same temperature for twenty minutes shows no decrease of the milk bacteria freshly implanted in it, and no increase for several hours. Similarly $149^{\circ} \mathrm{F}$., for forty minutes, resulted in the restraint of growth for nine hours. Exposure to $131^{\circ} \mathrm{F}$. for thirty minutes, or $140^{\circ} \mathrm{F}$. for twenty minutes, has been shown to destroy the germicidal activity of milk against $B$. lactis aerogenes, but had no influence upon its action on $B$. typhosus.

Fresh milk, drawn with aseptic precautions and planted with pure cultures of various pathogenic organisms, has shown a decrease in colonies in plate cultures, while sterilized milk has shown an immediate increase. Among the organisms tested are the germs of typhoid, cholera, diphtheria, dysentery and $B$. lactis aerogenes, a common lactic acid producer (35).

A given sample of milk may show a selective specific action with reference to its restraining action on different organisms. In a given sample one organism may immediately multiply, while another may not. It has been shown that the common lactic acid organisms in market milk usually increase from the beginning even when other forms are disappearing so rapidly that the total numbers are decreasing. It has been suggested that the leucocytes in milk destroy the bacteria by phagocytosis. This does occur to some extent, but it has been shown that it is not responsible for the great changes observed (35).

Some recent studies go to show that the decrease is more apparent than real. Agglutination occurs, and, with the mod- 
erate-agitation of making dilutions for plate cultures, ${ }^{*}$ these clumps would remain undisturbed (35). Thus, the number of colonies on the medium would decrease, while plates made from milk that had been most violently agitated would show an increase. This gives a reason for the discrepancies between the results of various workers, and goes a long way toward explaining the phenomenon.

It has been generally assumed by writers on the subject, that the decrease in numbers of colonies on plates indicated the death of the organisms concerned. Most writers considered this due to some germicidal property of milk. It has been suggested that many organisms die off in milk because they find there an environment wholly unsuited to them. This is undoubtedly true to some extent, but hardly accounts for some of the latest observations published. Agglutination seems to account for a large part of the apparent decrease in numbers. Even making allowance for this, it is evident that raw milk exerts a restraining influence on the multiplication of bacteria as compared with heated milk. In the light of this view, the phenomenon might be described as similar to the action of a weak antiseptic (35).

The evidence at hand does not warrant recommending a change in the general practice of rapid cooling of milk. That is, it has not been proven that delay in cooling would improve the keeping quality. It is certain, though, that the phenomenon should be taken into consideration in judging the success of efforts to secure germ-free milk. The length of time after milking, and the temperature, should be taken into consideration when various bacterial determinations are compared, and submitted as evidence of success in aseptic milking. For instance, the work reported in Ref. 69, Chap. I, was apparently done without recognition of this important factor.

*'The common method of counting bacteria is described in Chap. VIII. 


\section{REFERENCES.}

1. ADAMETz. Untersuchungen über Bacillus lactis viscosus, einen weit verbreiteten milchwirtschaftlichen Schädling. Landw. Jahrb., Berlin, 1891, S. 175 .

2. Adametz. Centbl. Bakt., etc., 2. Abt., Bd. VI, 1900, No.12, S. 406.

3. Alvord and PEARson. The milk supply of two hundred cities and towns. Bul. No. 46, Bur. Anim. Ind., U. S. Dept. Agr., 1903.

4. Berriner. Milk during transportation. Cir. No. 117, Bur. Anim. Ind., U. S. Dept. Agr., Washington, D. C., p. 27.

5. Bouska. Studien über den Antagonismus zwischen Milchsäurefermenten und Bakterien der Gruppe des Bacillus subtilis. Landw. Jahrb. Schw., 1903.

6. BURR. Investigations on the sources of the acid organisms concerned in the souring of milk. Thirteenth Ann. Rept. Storrs Agr. Exp. Sta., Storrs, Conn., 1900, p. 66.

7. BURR. The source of the acid organisms of milk and cream. Centbl. Bakt., etc., 2. Abt., Bd. VIII, 1902, No. 8, S. 236.

8. Cons. Bacteria in milk and its products. Philadelphia: P. Blakiston's Son \& Co., 1903.

9. Cons. The relation of temperature to the keeping quality of milk. Bul. No. 26, Storrs Agr. Exp. Sta., Storrs, Conn., 1903.

10. CoNn and EsTEN. The comparative growth of different species of bacteria in normal milk. Fourteenth Ann. Rept. Storrs Agr. Exp. Sta., Storrs, Conn., 1901, p. 13.

11. Conn and Esten. The effect of different temperatures in determining the species of bacteria which grow in milk. Sixteenth Ann. Rept. Storrs Agr. Exp. Sta., Storrs, Conn., 1904, p. 27.

12. Conn, ESTEN and STOcking. A classification of dairy bacteria. Eighteenth Ann. Rept. Storrs Agr. Exp. Sta., Storrs, Conn., 1906, p. 91.

13. Conn and Stocking. Studies concerning the so-called germicidal action of milk. Rev. Gén. Lait, Vol. II, Nos. 12 and 13.

14. DOANE. Economical methods for improving the keeping qualities of milk. Bul. No. 88, Maryland Agr. Exp. Sta., College Park, Md., 1903.

15. DOANE. The milk supply of twenty-nine soutliern cities. Bul. No. 70, Bur. Anim. Ind., L. S. Dept. Agr., Washington, D. C., 1905.

16. HARrison. The viscous fermentation of milk and beer. Trans. Roy. Soc. Canada, Second Series, 1905-1906, Vol. XI, Sec. IV, p. 71.

17. Heinemann. The significance of streptococci in milk. Jour. Infect. Diseases, Vol. III, 1906, No. 2, p. 173. 
18. HeinemanN. The kinds of lactic acid produced by lactic acid bacteria. Jour. Biol. Chem., Vol. II, 1907, No. 6, p. 603.

19. HIL, and SLACK. Bacterial counts of Boston's milk supply. Amer. Jour. Pub. Hyg. and Jour. Mass. Assoc. Bds. Health, Vol. XIV, 1904, No. 4, N. S. Vol. I, No. 1, p. 236.

20. HUNZIKER. Investigations concerning the germicidal action in cow's milk. Bul. No. 197, Cornell Univ. Agr. Exp. Sta., Ithaca, N. Y.

21. KASTI. The cliemistry of nillk. Bul. No. 41, Hyg. Lab., U. S. Pub. Health and Mar. Hosp. Serv., Washington, D. C., 1908, p. 309.

22. KunTzE. Gewinnung keimarmer Milch. Centbl. Bakt., etc., 2. Abt., Bd. XX, Nos. 12 und 14, S. 420.

23. LöHNis. Versuch einer Gruppierung der Milchsäurebakterien. Centbl. Bakt., etc., 2. Abt., Bd. XVIII, S. 97.

24. Marshal,. Ropiness in milk. Bul. No. 140, Mich. State Agr. Col. Exp. Sta., Agricultural College, Mich., 1897.

25. MARShal, I. A preliminary note on the associative action of bacteria in the souring of milk and in other milk fermentations. Special Bul. No. 23, Mich. State Agr. Col. Exp. Sta., Agricultural College, Mich., 1904.

26. MARSHALI. Extended studies of the associative action of bacteria in the souring of milk. Special Bul. No. 33, Mich. State Agr. Col. Exp. Sta., Agricultural College, Mich., 1905.

27. MARShALI, and FARRAND. Bacterial associations in the souring of milk. Centbl. Bakt., etc., 2. Abt., Bd. XXI, No. 1, 1908, S. 7.

28. METCHNikoff, trans. by Mitchell. The prolongation of life. N. Y. and London: G. P. Putnam's Sons, 1908.

29. MOORE. Bacteria in niilk. Circular published by the Commissioner of Agriculture of New York, Albany, 1902.

30. MÜLI,ER. Vergleichende Untersuchungen über Milchsäurebakterien (des Typus güntheri) verschiedener Herkunft, nebst Beitrag zur Frage der Stellung dieser Organismen zu den typischen Streptokokken. Centbl. Bakt., etc., 2. Abt., Bd. XVII, S. 468.

31. PARK. The great bacterial contamination of the milk of cities, can it be lessened by the action of health authorities? New York University, Bul. Med. Sci., Vol. I, 1901, p. 71.

32. Pennington. Bacterial growth and chemical changes in milk kept at low temperatures. Jour. Biol. Chem., Vol. IV, 1908, Nos. 4 and 5 , p. 353.

33. REvis. The acid coagulation of milk. Jour. Hyg., Vol. 7, p. 216.

34. Rosenau. The number of bacteria in market milk and the value of bacterial counts. Bul. No. 41, U. S. Pub. Health and Mar. Hosp. Serv., Washington, D. C., 1908, p. 421. 
35. Rosenau and McCoy. The germicidal property of milk. Bul. No. 41, Hyg. Lab., L'.S. P'ub. Health and Mar. Hosp. Ser'., Washington, D. C., p. 449.

36. RUSSELL. Outlines of dairy bacteriology. Madison, Wis.: H. L. Russel1, 1899.

37. Savage. The coagulation of milk by Bacillus coli communis. Jour. Path. and Bact., Vol. 10, 1908, p. 90.

38. STEWART and ATWOOD. Bacteria in milk and artificial refrigeration for dairymen. Bul. No. 111, West l'irginia Lniv. Agr. Exp. Sta., Morgantown, W. Va., 1908.

39, ST. John and PENington. The relative rate of growth of milk bacteria in raw and pasteurized clean milk. Jour. Infect. Dis., Vol. IV, 1907, No. 4, p. 647.

40. STocking. The so-called germicidal property of milk. Bul. No. 37, Storrs Agr. Exp. Sta., Storrs, Conn.

41. Ward. Ropiness in milk and cream. Bul. No. 165, Comell Uniz. Agr. Exp. Sta., Ithaca, N. Y., 1899.

42. WARD. Further observations upon ropiness in milk and cream. Bul. No. 195, Comell l'niz'. Agr. Exp. Sta., Itlaca, N. Y., 1901.

43. Whitaker. The milk supply of Boston and other New England cities. Bul. No. 20, Bur. Anim. Ind., I. S. Dept. Agr.. Washington, D. C., 1898.

44. Whitaker. The milk supply of Boston, New York and Philadelphia. Bul. No.81, Bur. Anim. Ind., I'. S. Dept. Agr., Waslington, D. C., 1905.

45. Wol.F. Zur Kenntnis der Veränderungen in der Bakterienflora der frischen Milch wälırend der sogennanten Inkubationsstadiums. Centbl. Bakt., etc., 2. Abt., Bd. XX, 1908, No. 18, S. 545. 


\section{CHAPTER III.}

\section{EPIDEMIC DISEASES TRANSMITTED BY MILK.}

Transmission of diseases of man by milk. Milk traffic as now constituted, offers a particularly favorable channel for the transmission of certain diseases of man. The close contact of human beings incident to the handling of milk at the producing dairies, coupled with the general lack of observance of aseptic precautions in the work, offer frequent opportunities for contamination of the product. Milk offers conditions that are not unfavorable to the bacteria of typhoid fever and diphtheria, and they may even multiply therein. The unrecognized virus of scarlet fever likewise finds conditions favorable.

The wide use of milk among households gives opportunity for very broad distribution of infection through milk. The output of a dairy may not go to the same consumers from day to day, so the field for the possible infliction of damage by a dairy is yet more widened.

Character of milk-borne epidemics. The large well-marked epidemics borne by milk are characterized by the almost simultaneous appearance of cases among patrons of the milk route. Variations occur, due to individual idiosyncrasy with respect to the incubation period of the disease. As likely as not the primary cases, attributable to the milk, will cease to occuir as suddenly as they began. Later, there will be observed secondary cases among members of the same or different households. The causative relation of milk stands out most clearly in outbreaks derived entirely from milk, and not complicated by the concurrent presence of the disease due to other quite different channels of dissemination (18).

Very thorough study of reported cases of typhoid and diphtheria in a city, with reference to the milk supply, have led to the conclusion that milk is responsible for many isolated cases 
of these diseases. That is to say, these diseases may occur as a result of contaminated milk, and escape notice ordinarily.

Typhoid fever. Typhoid is the most common of the epidemic type of infectious diseases. Little by little it is beginning to be recognized that milk stands next to water as a means for spreading infection. In this connection it is interesting to note that typhoid fever is relatively more prevalent in rural districts than in cities. Fulton has collected the following figures, quoted by Whipple (38):

TABLE II.

TYPHOID FEVER IN URBAN AND RURAL POPULATIONS.

\begin{tabular}{|c|c|c|c|c|c|c|}
\hline & & & & & $\begin{array}{c}\text { Av. } \% \text { of } \\
\text { rural } \\
\text { popula- } \\
\text { tion. }\end{array}$ & $\begin{array}{c}\text { Av. } \\
\text { typhoid } \\
\text { rate per } \\
1000 . \\
\end{array}$ \\
\hline \multicolumn{7}{|c|}{5 states with urban population of more than $60 \%$ of total ...... $30 \ldots \ldots .25$} \\
\hline 6 & “ & “ & “، & “، & of 40 to $60 \%$ of total $\ldots \ldots \ldots$ & ..... 42 \\
\hline 7 & “ & “ & ““ & $\because$ & of 30 to $40 \%$ of total. & 38 \\
\hline 8 & “ & “ & “، & “ & of 20 to $30 \%$ of total.. & ...... 46 \\
\hline 12 & “ & “ & “ & “، & of 10 to $20 \%$ of total. & ...... 62 \\
\hline 12 & “6 & “ & “ & “ & of 0 to $10 \%$ of tota $1 \ldots$ & …. 67 \\
\hline
\end{tabular}

Investigations in the District of Columbia. During the past two years very thorough investigations have been made of the source of infection of the typhoid fever cases occurring in the District of Columbia during the months May to October inclusive. The work was instituted in consequence of the observation that the installation of a satisfactory system of water filtration did not produce a satisfactory lowering of the typhoid fever rate. In 1906 it was possible to definitely assign a source of infection in the case of only $18.6 \%$ of all reported cases believed to have originated in the District. .Among these, $11.3 \%$ of all were attributed to milk and $7.3 \%$ to contact. That is, $60.8 \%$ of all traceable cases were milk-borne. In 1907 , the figures were: traceable to milk, $9.18 \%$; to contact, $19.50 \%$; total accounted for, $28.68 \%$. In that year $32 \%$ of all traceable cases were attributed to milk. 
The careful study of the cases of typhoid fever in the District of Columbia with reference to the source of the milk, has made it possible to compile figures showing the amount of that disease traceable to each dealer. The results appearing in the reports $(28,29)$ on the work are rearranged in the appended table.

In 1906 definite outbreaks of typhoid fever were attributed to dairies No. 4 and No. 13. Note the difference in the rate of typhoid attributed to these dairies in 1907, when no outbreaks occurred among their customers. In 1907, dairy No. 163 was the source of an outbreak.

Dairy No. 10 makes a very fine showing during both seasons, attributed to the fact that efficient methods for sterilizing the bottles and for pasteurizing the milk were used. The good showing of dairy No. 17, in 1908, may be attributed to the fact that an efficient method of sterilizing bottles was used and to the fact that a portion of the milk was derived from a special dairy. Suspected outbreaks were attributed to dairies Nos. 8 , 44 and 46 in 1907.

The work on typhoid fever in the District of Columbia led Rosenau, Lumsden and Kastle to the conclusion that infected milk is one of the important known factors in the spread of the disease there. This view concerning the relation of milk to the spread of the disease has been expressed by others.

Importance of milk as a carrier. Whipple writes, on page 132 of his book (38):

"In a general sort of way it may be said that in the cities of the United States, at the present tine, about 40 per cent. of the typhoid fever is due to water, 25 per cent. to milk, 30 per cent. to ordinary contagion (including fly transmission), and only about 5 per cent. to all other causes."

Neufeld (22) considers that milk is next in importance to water as a means for transmitting typhoid fever. Trask (32) has collected data concerning 317 milk-borne typhoid fever epidemics. Harrington (13) states that during two years the Massachusetts State Board of Health investigated 18 local epidemics of typhoid fever. Of these, 14 were milk-borne, 3 due to water, and 1 unexplained. The importance of milk in connection with typhoid has till lately been underestimated. 
TABLE III.

TYPHOID FEVER IN THE DISTRICT OF COLUMBIA WITH REFERENCE TO THE MILK SUPPLY.

1906

May to October inclusive.

\begin{tabular}{|c|c|c|c|c|c|c|c|}
\hline & & 1906 & & & 190 & & \\
\hline $\begin{array}{l}\text { Dairy } \\
\text { No. }\end{array}$ & $\begin{array}{l}\text { No. } \\
\text { Cases. }\end{array}$ & $\begin{array}{l}\text { Gallons of } \\
\text { Milk Sold. }\end{array}$ & $\begin{array}{c}\text { No. Cases } \\
\text { per } \\
100,000 \text { gals. } \\
\text { Milk Sold. }\end{array}$ & $\begin{array}{l}\text { No. } \\
\text { Cases. }\end{array}$ & $\begin{array}{l}\text { Gallons of } \\
\text { Milk Sold. }\end{array}$ & $\begin{array}{c}\text { No. Cases } \\
\text { per } \\
100,000 \text { gals. } \\
\text { Milk Sold. }\end{array}$ & $\begin{array}{l}\text { Dairy } \\
\text { No. }\end{array}$ \\
\hline 1 & 26 & 142,986 & 18.2 & 19 & 268,724 & 7.1 & 1 \\
\hline 2 & 29 & 134,911 & 21.5 & 50 & 214,030 & 23.4 & 2 \\
\hline 3 & 20 & 119,889 & 16.6 & 11 & 154,963 & 7.1 & 3 \\
\hline 4 & 54 & 102,867 & 52.5 & 32 & 148,352 & 21.6 & 4 \\
\hline 5 & 17 & 77,098 & 22.0 & 10 & 137,516 & 7.2 & 5 \\
\hline 6 & 17 & 71,690 & 23.7 & 20 & 135,044 & 14.8 & 6 \\
\hline 7 & 25 & 71,350 & 35.0 & 16 & 117,365 & 13.6 & 7 \\
\hline 8 & 23 & 62,903 & 36.6 & 22 & 128,800 & 17.1 & 8 \\
\hline 9 & 18 & 51,115 & 35.2 & 9 & 100,800 & 8.9 & 9 \\
\hline 10 & 3 & 44,496 & 6.7 & 8 & 147,107 & 5.4 & 10 \\
\hline 11 & 8 & 43,800 . & 18.2 & 7 & 85,558 & 8.2 & 11 \\
\hline 12 & 5 & 39,286 & 12.7 & 10 & 89,240 & 11.2 & 12 \\
\hline 13 & 41 & 35,995 & 113.9 & 6 & 92,602 & 6.5 & 13 \\
\hline 14 & 7 & 31,984 & 21.9 & 4 & & & 14 \\
\hline 15 & 2 & 31,542 & 6.3 & 5 & & & 15 \\
\hline 16 & 4 & 29,247 & 13.7 & 4 & 49,395 & 8.1 & 16 \\
\hline 17 & 5 & 27,247 & 18.4 & 2 & 38,637 & 5.2 & 17 \\
\hline 18 & 7 & 24,829 & 28.2 & 2 & 42,540 & 4.7 & 18 \\
\hline 19 & 9 & 22,005 & 40.9 & & & & 19 \\
\hline 20 & 4 & 14,145 & 28.3 & & & & 20 \\
\hline 21 & 1 & 13,909 & 7.2 & & - & & 21 \\
\hline 22 & 1 & 12,845 & 7.8 & & & & 22 \\
\hline 23 & 3 & 11,617 & 25.8 & & & & 23 \\
\hline 24 & 3 & 11,617 & 25.8 & & & & 24 \\
\hline 25 & 4 & 11,304 & 35.4 & & & & 25 \\
\hline 26 & 1 & 11,187 & 8.9 & & & & 26 \\
\hline 27 & 0 & 11,070 & 0.0 & & & & 27 \\
\hline 28 & 3 & 10,836 & 27.8 & & & & 28 \\
\hline 29 & - & & & & & & 29 \\
\hline 30 & 4 & 9,697 & 41.2 & & & & 30 \\
\hline 31 & 4 & 9,328 & 42.9 & & & & 31 \\
\hline 32 & 1 & 8,320 & 12.0 & & & & 32 \\
\hline 33 & 1 & 7,855 & 12.8 & & & & 33 \\
\hline 34 & 1 & 7,723 & 12.9 & & & & 34 \\
\hline 35 & 4 & 6,028 & 66.4 & & & & 35 \\
\hline 36 & 4 & 5,225 & 76.5 & & & & 36 \\
\hline 37 & 1 & 3,872 & 25.8 & & & & 37 \\
\hline 38 & 1 & 3,182 & 31.4 & & & & 38 \\
\hline 39 & 1 & 3,028 & 33.0 & & & & 39 \\
\hline 40 & 1 & 2,168 & 46.1 & & & & 40 \\
\hline 41 & 0 & 1,353 & 0.0 & & & & 41 \\
\hline $\begin{array}{l}\text { Not } \\
\text { months }\end{array}$ & Thes & ios calcu & 1 for the & $\begin{array}{l}18 \\
31\end{array}$ & $\begin{array}{l}61,399 \\
10,955\end{array}$ & $\begin{array}{r}29.3 \\
282.9\end{array}$ & $\begin{array}{r}46 \\
163\end{array}$ \\
\hline
\end{tabular}


Sources of the contamination of milk. The means by which typhoid fever bacilli are disseminated by the individual offer frequent opportunity for the infection of milk. The typhoid patient is believed by some to disseminate the disease during the incubation period and early stages of the disease. Certain it is that patients, long before taking to bed, disseminate bacilli through the urine and feces. This is equally true of walking cases that never take to bed. The danger is augmented by the fact that diagnosis may be delayed until the second or third week, and in the mild cases no diagnosis is made, and thus no warning is given.

The patient in bed is a menace through the careless disposal of excreta. Thus, infection may be disseminated through the nurse, by flies when allowed access to discharges on the ground or in open vaults, and by the contamination of the well or stream. All these factors may play a part in milk infection on a dairy farm.

The convalescent may return to work while yet disseminating infection. A considerable number of those recovering from typhoid for years afterwards continue to disseminate infection. Such cases or others harboring bacilli, with no previous history of typhoid fever, are called bacilli carriers, and are believed to be significant factors in the spread of the disease (25). Adequate means for protecting the public from this source of danger have not yet been put into general practice.

In the dairy there are certain practices that facilitate the infection of milk. The failure to wash the hands before milking and the common practice of wetting the hands with milk are particularly dangerous. As likely as not the milker may be acting as nurse in the sick room.

Conditions that would permit flies to come in contact with milk or the cans are common in dairies.

Common practice in connection with the care of utensils leaves many opportunities for contamination by polluted water. Oftentimes, the milking utensils are not scalded after the evening's milking, but are merely rinsed in cold water. The scalding given utensils is very apt to be inefficient and does 
not protect against the dangers of water. Poor scalding is a serious matter in connection with bottles that may have been in the sick room. Water may get directly into the milk from leaks in milk coolers, or by intentional adulteration. The distributing stations in the city and various places where milk is sold, furnish their quota of opportunities for the infection of milk.

Detection of milk-borne typhoid fever epidemics. Milk-borne epidemics are most quickly detected through a system of ascertaining early the facts regarding the possible sources of infection among the reported cases. The health officer should keep a card for each dairyman, and post up the cases occurring among his present patrons, or those that took the milk at any time within a month previous to attack. An unusual number will direct attention to the necessity for an investigation (39). A large proportion of children among those infected would place the milk supply under particular suspicion.

Bacteriological examinations are not available for anticipating milk-borne trouble, nor usually for demonstrating the presence of the organisms in the milk. The technical difficulties are too great to take up the search for the typhoid organism in the hope of obtaining decisive useful results. The same holds true of the examination of water, in connection with a typhoid epidemic. In the case of both milk and water, one difficulty lies in the fact that the organisms may not be present at the time suspicion is aroused. The facts must be determined by epidemiological evidence. The writer has found very useful a 3 by 5 -inch card printed for the reception of information on the following points, slightly changed from one used in working up the Palo Alto epidemic (8).

STATE HYGIENIC LABORATORY.

UNIVERSITY OF CALIFORNIA, BERKELEY.

Patient's name

Address

Date $\left\{\begin{array}{l}\text { of first symptoms } \\ \text { of taking to bed } \\ \text { of physician's first visit }\end{array}\right.$ 
Place of work, business, or school

Physician while ill

Health before attack

Out of town (date)

Patient discharged by physician (date).

Symptoms $\left\{\begin{array}{l}\text { Chills } \\ \text { Vomiting } \\ \text { Headache } \\ \text { Fever }\end{array}\right.$

$\begin{array}{ll}\text { Pain in Bowels } & \text { Tongue } \\ \text { Nosebleed } & \text { Delirium } \\ \text { Diarrhœea or } & \text { Eruption } \\ \text { Constipation } & \text { Spleen }\end{array}$

[REVERSE.]

TYPHOID FEVER.

Examination No

Widal reaction:

$\left.\left.\begin{array}{l}\text { Made?..... Date when } \\ \text { (Yes or No) Positive }\end{array}\right\} \quad \begin{array}{c}\text { Date when } \\ \text { Suggestive }\end{array}\right\}$....................

Complications

Drinking Water $\left\{\begin{array}{l}\text { Town supply } \\ \text { Private well }\end{array}\right.$

\section{Milkman}

Milk delivered $\left\{\begin{array}{l}\text { A.M. } \\ \text { P. M. }\end{array}\right.$

Source of cream and? extra milk supply

Previous cases in the house

Has patient visited other cases?

Privy or water closets

Plumbing

What probable sources of infection

What possible sources of infection

Remarks

A more elaborate blank for data is employed by the Hygienic Laboratory, U. S. Public Health and Marine Hospital Service, in the study of typhoid fever in the District of Columbia (29):

PUBLIC HEALTH AND MARINE HOSPITAL, SERVICE-HYGIENIC LABORATORY.

TYPHOID FEVER CASE CARD.

Date of investigation.

Case No.

Name

Age

Color

Sex

Nationality.

Probable date of onset

Date of definite symptoms.

Name and address of physician:

Residence

Residence in D. C.

Residence when taken sick.

from to 
Previous residences froll1 _...... to

Subsequent residences from to

Temporary absences from D. C. within 30 days prior

Number of occupants

Ages
“
،
who have had typhoid
When?

Newcomers in house within three months prior

، " had typhoid?

Servants-

White: Resident

Typhoid?

Non-resident

Colored : Resident

Typhoid?

\section{Non-resident}

Typhoid at homes of servants

Disposal of sewage

W. C. in yard

Privy

Typhoid?

Typhoid?

When?

General sanitary condition of residence

IV. C. in house

\section{Location}

OCCUPATION.

Place from to.

Other cases

WATER WITHIN 30 DAYS PRIOR.

Solely

Principally

Occasionally

FOOD WITHIN 30 DAYS PRIOR.

Where taken

Milk (how used) ....................................... From

Boiled?

Pasteurized?

Ice Cream?

Where?

Uncooked fruits and vegetables

Shellfish

CONTACTS.

Association 30 days prior with patients in febrile stage

“ with suspected cases

" with persons who have had typhoid within 6 months

1 year.
2 years
3 years
4 years
5 years

Association 30 days prior with persons in contact with patients in febrile stage

Treatment of stools and urine of patients. 
Other precautions

Remarks

Summary

Signature.

In tracing back the milk from the patient to the source, it will be found that many milk routes may derive their supply in part or whole from the dairy under suspicion. Record of the facts is facilitated by making a diagram with lines indicating the course of the various milk supplies from the producer to the distributing station and on to the milk routes. At the dairy under suspicion, the inquiries and observations that might be made, and corrective measures to be required, are obvious. A dairy can by no means be freed from suspicion even if 110 typhoid patients or convalescents are found there. Widal tests might bring to light a convalescent from a mild unrecognized attack. There is always the possibility that the infection of the milk has resulted from a bacilli carrier and to detect such a person requires a bacteriological examination of the feces and urine. A case of infection of milk from a typhoid bacilli carrier has recently occurred in Washington, D. C.

Berkeley, Cal., outbreak. A small milk-borne epidemic that has been brought to the attention of the writer illustrates well the bad conditions that may prevail (35).

During the last half of October, 1906, there were 20 cases of typhoid fever reported to the health officer. A study of the cases with reference to water supply had eliminated that source of infection from consideration, and information was secured that many of these cases had very likely been contracted in a nearby city where typhoid was prevalent. Ten of the cases, reported from October 15 th to 29 th, were all supplied with milk from the same dealer. The last case of typhoid on this milk route was a son of the dairyman, who, but a few days before, had been delivering milk.

A visit to the home where he lay sick revealed dangerous conditions. No professional nurse was employed. The privy, 
a temporary affair, had no vault and 110 protection from flies. Not ten feet from it, the milk cans were washed in a temporary shed. In this was found a washtub filled with milky water, indicating that it had recently been used for milk cans. These conditions are shown in Fig. 8.

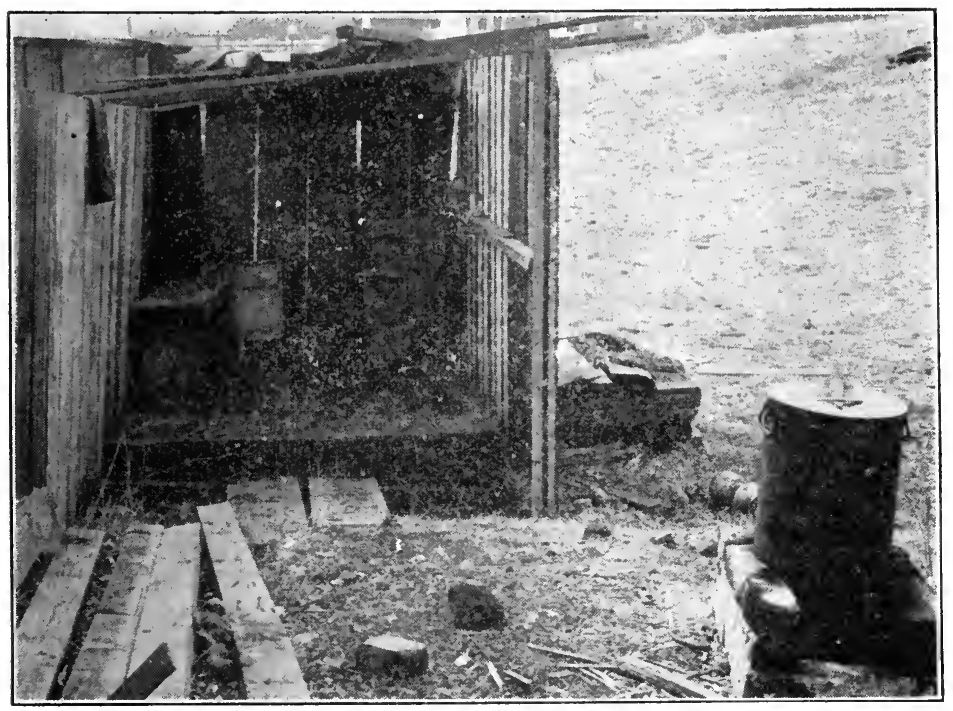

Fig. S. Laundry in which milk cans were a'ashed.

The family washing on the clothes line, and washboard in the shed by the tub, indicated that the tub was also utilized for laundry purposes. Some eighteen delivery cans, measures, etc., were on pegs nearby. Water for scalding cans was heated over a fire in a small tank, supported by a few bricks. The supply of water from this source would be ridiculously inadequate for the proper scalding of utensils. The general conditions are shown in Fig. 9. The building on which the milk cans hang contained a case of typhoid fever on the second floor, besides housing the family, while the basement was used as a stable. Note in order, from left to right, family washing, tank for heating water, shed (beyond horse) for can washing, and privy in fence corner. 
The milk delivered by this dealer, not great in amount, was not brouglit to the house before delivery. The cans only were brought there for washing. It was learned that a carpenter employed on the premises had recently recovered from an attack of typhoid fever. It is quite possible, too, that the boy who had been delivering nill may have been disseminating infection previous to taking to bed. The dairyman was required to have the can-washing done elsewhere, after which no further trouble was traceable to the dairy.

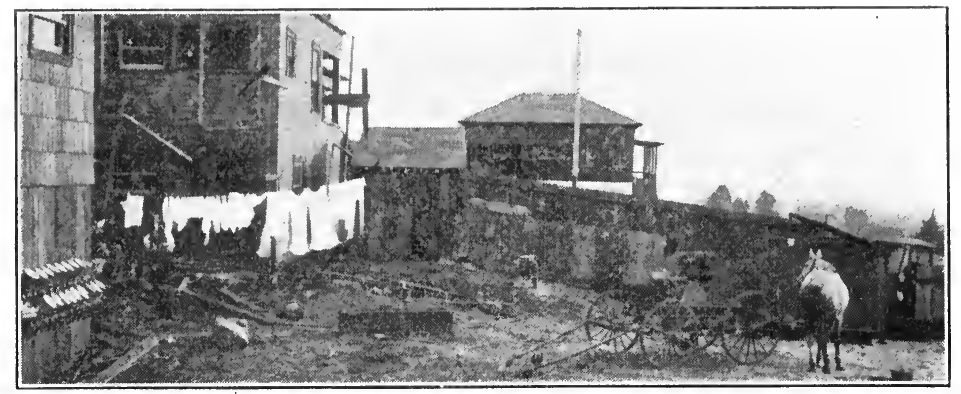

Fig. 9. Conditions surrounding a case of typhoid fever.

The milk sold by this dealer was only a fraction of the ontput of a large dairy, the product of which was mostly sold in another city, and it was not practicable to trace it, there. A visit to the dairy and inquiry among plysicians near there revealed no trouble.

Diphtheria. Recorded milk-borne epidemics of this disease are less common than in the case of typhoid fever. Trask (32) has collected important data concerning 51 milk-borne epidemics.

The fact that the conmmon seat of the disease is readily accessible for bacteriological examination, has resulted in the accumulation of exact information regarding the dangers of infection.

The clinical case of diphtheria, with a well-defined membrane, disseminates infection through any means that permit the transfer of saliva. Danger of infection is not confined however to 
the recognized clinical case. During convalescence, the virulent bacilli may persist in the nose or throat for months after the patient has been discharged as cured, unless the culture method has been used to determine the time for release from quarantine. The condition is quite parallel to the typhoid bacilli carriers. Likewise, diphtheria bacilli may be isolated from the nose or throat in advance of the appearance of clinical symptoms.

The worst of the matter is the fact that diphtheria exhibits all degrees of severity down to examples of healthy persons harboring virulent diphtheria bacilli. These may be quite as dangerous as the recognized clinical cases. The appearance of clinical diphtheria in an individual is governed in part by the state of the resistance of the individual exposed to infection.

The significance of these so-called germ cases is attracting careful attention in the study of the spread of diphtheria. They amount to not over $4 \%$ of the community in the absence of an epidemic, but in infected households the percentage of germ cases rises to $50 \%$ of the individuals exposed. Some cases are practically always found in fanilies where infection exists. This class of unrecognized carriers of infection, rather than the recognized cases under treatment, is regarded as the chief source for the dissemination of diphtheria in a community $(16,36,37)$.

In a dairy, a convalescent or germ case may be a milker. A cough or a sneeze, or any means by which saliva may get on the hands, and hence to the milk, results in its contamination with diphtheria. Moore (19) has reported an epidemic in Ithaca, N. Y., traceable to a convalescent.

Observations tending to implicate the cow as a source of diphtheria, are not supported by convincing facts (3).

Recognition of milk-borne diphtheria epidemics. Reported cases must be promptly investigated with reference to the milk supply, and investigation of the dairy should be made in case of suspicion. Bacteriological examinations of milk rarely result in the discovery of Bacillus diphtheriae $(2,7,20)$. At the dairy, inquiry and physical examination of throats should not be relied upon to the exclusion of taking cultures from both 
throat and nose of all persons about the establishment. The results will very likely bring to light facts which may not have been recognized, or which had been suppressed.

The precautions to be observed upon the detection of diphtheria in a dairy are obvious. Sale of the milk, raw, should be interdicted as long as a single person about the place harbors diphtheria bacilli. Certainty on this point should be established by two or three negative cultures at intervals of a few days, each set being taken simultaneously from the nose and throat of all individuals concerned. The quickest way to resume the sale of milk would be to exclude patients and germ cases from the premises.

Milk-borne diphtheria in Oroville, Cal. The writer has used cultures to confirm suspicion of a dairy as the cause of an epidemic, when 110 history of clinical diphtheria could be elicited $(34,35)$.

Diphtheria was apparently introduced into the town by a visitor who had recently recovered from the disease elsewhere. One case was reported on November 14th, shortly after the arrival of the visitor in the family. No more cases were reported for six weeks.

From December 25, 1907, until January 25, 1908, cases were reported in 15 families. Six of these families consumed milk from the $\mathrm{R}-$ dairy. One of these 6 families was reported on December 25th, and the other 5 were reported during the 5 days, January 15 th to 20 th. Two other families gave a history of probable spread from the families on the milk route in question. Seven infected families in town gave no history of connection with the milk route.

The suspicions of the health officer were directed to the dairy by the number of infected families who were among its patrons and by the fact that few families consuming the milk escaped. A considerable portion of the milk was used by two cheap restaurants, and if any cases were contracted from the milk in these establishments, it was not possible to trace them.

The only people handling the milk were a man, his wife and daughter. Cultures were made from the nose and throat of each one. The mother and daughter gave positive cultures 
from the throat, while the man gave negative results. Bacilli persisted in the throat of the woman for three weeks in spite of constant effort to clear up the infection. No history of previous clinical diphtheria could be established, nor were clinical manifestations recognizable. The fact that the woman frequently milked the cows, handled the milk and delivered it, is of interest. Upon the discovery of the bacilli carriers at the dairy, the local authorities took measures to prevent further contamination of the milk.

Scarlet fever. Knowledge of the details concerning the infection of milk with scarlet ferer is restricted somewhat by the fact that there is no general agreement as to the causative agent of the disease. It is believed that the infections material resides in the throat, nasal secretions and skin (21). There is, though, good epidemiological evidence that milk infection with scarlet fever occurs frequently (32).

Milk-borne scarlet fever assumes a mild type (21). Newsholme (23) calls attention to the fact that "scarlet fever may be caused by infected milk containing the contagium in such an attenuated form or minute quantity that no symptoms manifest themselves except as anomalous sore throat with fever."

Investigation of the source of milk supply responsible for trouble, will reveal some rather close connection between a case of the disease and the milk. It may be a case in the house; bottles returned from a sick-room; a convalescent, or a nurse, or a patient's milking or handling milk.

The importance of milk as a carrier of scarlet fever is established by convincing evidence. Harrington (13) has reported a very extensive milk-borne scarlet fever epidemic that occurred in Cambridge, Boston, and Summerville, Massachusetts. In five days, 485 cases were reported anong the customers of one large dairy company. During a period of three weeks from the beginning of the trouble, 717 cases were reported in the district, of which $84 \%$ were annong the patrons of the dairy. The source of infection was traced to a man employed by the dairyman to taste milk, and who used the same spoon in sampling each lot of milk. The daughter of this man was in the 
desquanating stage of scarlet fever, and he himself showed markedly prominent papilla of the tongue. Trask (32) has collected information concerning 125 milk-borne scarlet fever epidemics.

Gastro-intestinal infections. The subject of clean $111 \mathrm{ilk}$ in its relation to health has been widely discussed in connection with the subject of infant feeding. One-third to one-half of all deaths under one year are due to gastro-intestinal disorders. The very heavy infant mortality from this class of diseases has occasioned careful scrutiny into the causes contributing thereto. It has been shown that $75 \%$ to $85 \%$ of those dying from this cause are artificially fed. During the summer the deaths from this cause rise, while those from other causes remain stationary. In Paris, "the diarrheal death rate in breast-fed infants, varies from a minimum of 2 per thousand in winter to a maximum of but 20 per thousand during the hot months; the diarrheal deaths of the artificially fed, fluctuate from a minimum of 12 per thousand in winter to a maximum of 158 per thousand in the summer' (31). The striking difference here, leads to the suspicion that the food is to blame.

Evidence of the injury done by cow's milk in this connection has not been completely worked out with reference to the species concerned. Suspicion has been directed against the peptonizing organisms, B. coli, B. proteus, streptococci, etc., or to toxic products resulting from their growth.

Streptococci as a cause of gastro-intestinal disturbances have been incriminated by agglutination experiments with the organisms found in the feces. It has been found that the serum of patients develops a specific agglutinating power for certain strains of streptococci found in the feces (6). Streptococci are demonstrable in practically all raw market milk. The difficulties of recognizing pathogenic streptococci in $111 \mathrm{k}$ are very great, because of the close resemblance of the common lactic acid producing bacteria. Streptococcus infections of the cow's udder are very common and there is ample opportunity for the infection of market milk (27). The subject is more completely discussed in Chap. VII.

Evidence has been adduced from observation of the different. 
effects of clean and of highly polluted milk in infant feeding. Clinical studies have shown that in hot weather children do the best on good milk, and the worst on bad milk (26). The marked decline in infant mortality in New York City, due for the most part to the decline in mortality from summer diarrhea, bears a close relation to the adoption of methods for rendering milk safe (9). Goler (11) has shown the very striking effect of reducing the bacterial content of a city milk supply, and has shown a remarkable coincidence of simultaneous decline of both bacterial count and infant death rate. The importance of house infection in epiclemic diarrhea, has been emphasized by Newsholme (24). He believes that the bulk of the infection in epidemic diarrhea is derived in some way within the house, and not derived from the farm. Sandilands holds similar views (30). In proportion to the number of consumers, he noted more diarrhea in infants fed on Nestlé's food containing a few bacteria, than those on cow's milk with phenomenal numbers of bacteria. He believes the disease to result from food infection, generally from the excrement of a patient. He emphasizes the importance of flies as agents in the transmission of infection.

\section{REFERENCES.}

1. Buvy. Streptococcus diarrhea in San Francisco (streptococcus gastro-enteritis). Pediatrics, Vol. XXI, No. 1, January, 1904.

2. Bowhil. . Milk, the vehicle of contagion in an outbreak of diphtheria. l'et. Record No. 561, April 8, 1899.

3. DEAN and ToDD. Experiments on the relation of the cow to nilikdiphtlieria. Jour. Hyg. (Cambridge), Vol. II, 1902, p. 194.

4. DELÁPINE. Milk and other food poisoning and epidenic diarrhea. Jour. Comp. Path. and Ther., Vol. XVI, 1903, p. 77.

5. EAGER. Morbility and mortality statistics as influenced by $111 \mathrm{llk}$. Bul. No. 41, Hyg. Lab., U. S. Pub. Health and Mar. Hosp. Serí., Washington, D. C., 1908, p. 229.

6. Eiditorial. Streptococcus infection of the intestinal tract. Jour. Amer. Med. Assoc., Vol. I, I, 1908, No. 15, p. 1236.

7. EYRE. The Bacillus diphtheriæ in milk. Brit. Med. Jour., Sept. $2,1899$. 
8. Fish. Typhoid fever epidemic at Palo Alto, California. Published by the Board of Health, Palo Alto.

9. FREFMAN. The reduction in the infant mortality in the city of New York and the agencies which have been instrumental in bringing it about. Hed. Nez's, Sept. 5, 1903.

10. Gertyr. Infant mortality in the summer months. Jour. Amer. Med. Assoc., Vol. J, 1908, No. 13, p. 1008.

11. Gol isk. Does the bacterial content of city milk influence the infantile death rate? Archiz. Ped., September, 1906.

12. Harrington. The problem of city milk supplies. Repts. and Papers of the Amer. Pub. Health Assoc., Vol. XXXII, Part I, p. 153.

13. Harrington. Milk as a carrier of infection. N. Y. Med.Jour., Vol. LXXXV, 1907, p. 696.

14. Haskfil. A typhoid fever epidemic from infecterl milk. Jour. Amer. Med. Assoc., Vol. L, 1908, No. 11, p. 846.

15. Hemenway. The scarlet fever epiclemic of 1907. Jour. Amer. Med. Assoc., Vo1. L, 1908, No. 14, p. 1115.

16. Hit, Time limit versus culture limit in diphtheria release. Amer. Jour. Pub. Hyg., Vol. XVII, 1907, No. 4, p. 318.

17. KLEIN. Pathogenic microbes in milk. Jour. Hyg. (Cambridge), Vol. I, 1901, p. 78.

18. LUMSDEN. The milk supply of cities in relation to the epiclemiology of typhoid fever. Bul. No.41, Hyg. Lab., U. S. Pub. Health and Mar. Hosp. Serv., Washington, D. C., 1908, p. 151.

19. Moore. The control of diphtheria in small cities and country districts from the bacteriological standpoint. N. Y. State Med. Jour., February, 1901.

20. Marshair.. Note on the occurrence of diphtheria bacilli in milk. Jour. Hyg.( Cambridge), Vol. VII, 1907, p. 32.

21. McVarl. The prevention of infectious diseases. London: Macmillan \& Co., 1907.

22. NeufeidD. Typhus. Handbuch der pathogenen Microorganismen, by W. Kolle and A. Wasserman11, Bd. II, S. 303.

23. NEWSHOL,ME. An outbreak of sore throats and scarlet fever caused by infected milk. Jour. Hyg. (Canbridge), Vol. II, 1902, p. 150.

24. Newshom Me. Domestic infection in relation to epidemic diarrhœe. Jour. Hyg. (Cambridge), Vol. VI, 1906, p. 139.

25. PARk. Typhoid bacilli carriers. Jour. Amer. Med. Assoc., Vol. LI, 1908, No. 12, p. 981. 
26. PARK and HoI,T. Report upon the results with different kinds of pure and impure milk in infant feeding in tenement houses and institutions of New York City : a clinical and bacteriological study. Archic. Ped., December, 1903.

27. REED and WARD. The significance of the presence of streptococci in market milk. Amer. Med., Vol. V, 1903, No. 7, p. 256.

28. Rosenau, LuMSDen and Kastit. Report on the origin and prevalence of typhoirl fever in the District of Columbia. Bul. No. 35, Hyg. Lab., L. S. Pub. Health and Mar. Hosp. Serz', Washington, D. C., 1907.

29. Rosenau, LUMSDEN and KASTI.E. Report No. 2 on the origin and prevalence of typhoid fever in the District of Columbia. Bul. No. At. Hyg. Lab., L. S. Pub. Health and Mar. Hosp. Serr'., Washington, D. C., 1908.

30. Sandiands. Fpidemic diarrloea and the bacterial content of food. Jour. Hyg. (Cambridge), Vol. VI, 1906, p. 77.

31. Scherfschewsky. Infant feeding. Bul. No. 41, Hyg. Lab., U.S. Pub. Health and Mar. Hosp. Serv., Washington, D. C., 1908, p. 631.

32. Trask. Milk as a cause of epidemics of typhoid fever, scarlet fever and diphtheria. Bul. No.41, Hyg. Lab., L.S. Pub. Health and Mar. Hosp. Serv., Washington, I). C., 1908, p. 21.

33. Trask. Milk in its relation to infectious diseases. Jour. Amer. Med. Assoc., Vol. LI, 1908, No. 18, p. 1491.

34. WARD. Notes on diphtheria. Nonthly Bul. Cal. State Board of Health, Vo1. III, 1908, No. 10, p. 110.

35. WARD. Report of the department of hygiene. Taientieth Biennial Report of the State Board of Health of California.

36. WARD and HENDERSON. The control of diphtheria in a public school. Cal. State Jour. Med., August, 1907.

37. Whsbrook. Diphtheria infection in Minnesota. Jour. Amer. Med. Assoc., March 25, 1905.

38. WHIPPLE. Typhoid fever, its causation, transmission and prevention. New York: John Wiley \& Sons, 1908.

39. WOODWARD. The municipal regulation of milk supply of the District of Columbia. Bul. No.41, Hyg: Lab., U. S. Pub. Health and Mar. Hosp. Serv., Washington, D. C., 1908, p. 679. 
CHAPTER IV.

\section{BOVINE TUBERCULOSIS AND OTHER CATTLE DISEASES.}

Bovine tuberculosis. (The subject of bovine tuberculosis and its relations to the milk supply cannot be adequately discussed without a consideration of the relations of the disease in its purely economic aspects.)

Losses to the live stock industry. (The disease is a tremendous source of loss to the live stock industry, and worse yet, the majority of those men suffering the loss have not awakened to the idea of the possibility of prevention. Precautions for the control of tuberculosis have not yet been generally recognized as a necessary detail in the management of the live stock or dairy business. Losses are sustained by the decrease in production from diseased animals by death, long before the expiration of the natural life period, and by condemnation of carcasses in the abattoir, in cases where an adequate meat inspection system is maintained (17). These facts have been recognized by a few, and the means of transmission have been determined, even though the facts have not been acted upon in the United States extensively enough to check the disease.)

Transmission by milk. (Milk is one great factor in the spread of tuberculosis among cattle. Slaughter-house statistics gathered from observations on pregnant animals have demonstrated, if such demonstrations were needed, that tuberculosis is very rarely inherited. The common practice in raising dairy calves has been for a long time to separate them from the cows early and feed them on skim-milk. It is under these conditions that an appalling amount of infection of calves occurs (37). The recognition of this source of tuberculosis and its elimination by heating the milk, has afforded the basis for the most prac- 
ticable scheme yet devised for the control of tuberculosis, the Bang method $(21,22,23,34,35,36,38,39,54)$.

Infection of swine. (But the tubercular cow is not merely a menace to her young through the milk, but also casts a blight upon the industry of pork production. The pig is particularly susceptible to bovine tuberculosis. In districts where it is the common practice to feed pigs on skim-milk and whey, the results occasion the condemnation of such a high per cent. of carcasses that buyers have learned to avoid certain districts on this account. In any event, they pay a price for pork lowered in anticipation of their losses from condemned carcasses or parts.

Milk is not the only common means for the transmission of tuberculosis by cattle. In the corn belt, pigs are raised in

$\int$ association with beef cattle, so that they may utilize the feces of cattle for feed. The magnitude of the losses occasioned in this way has drawn attention to the matter of contamination by feces as a source of the tubercle bacilli in 1uilk $(41,42,43)$.

Insidious onset. The insidious nature of the disease masks its presence and wholly misleads the dairymen as to the number of his cattle that are tubercular. A cow may be in fine condition and apparently perfect health, and on slaughter show the most serious advanced stage of involvement of the internal organs. This is so common that the diagnosis by physical examination by a veterinarian is entirely unsatisfactory.

Conditions governing prevalence. The prevalence of tuberculosis in herds seems to depend to a large extent upon the number of opportunities that have been offered for the possible introduction of infection. Small herds which have been built up of calves raised on their mothers' milk, will be found in the best condition (55). The large herds supplying city milk are conducted upon a different plan. Dry cows are frequently sold, and their place taken by cows which have been bought shortly before calving. Calves are butchered, for whole milk is too precious to feed them and no skim-milk is available. Under these conditions, there is every opportunity offered for the introduction of tuberculosis. Among the dairies in which calves are raised on skin-milk, a different source of infection 
is afforded. It is the practice for dairymen supplying creameries to take back skim-milk to feed to the calves. This skimmilk is mixed indiscriminately at the creamery, and thus a ready means for the dissemination of the disease from herd to herd is afforded. The heating of skim-milk, whey, etc., at the factories, to kill the tubercle bacilli before distribution to the dairymen for feeding purposes, is an important measure for restricting the spread of the disease. It has been made compulsory in some states.

Prevalence in herds. (It is rarely that figures on the number of reacting animals in large herds stupplying market milk are available; for the conditions are so bad that owners are cantious. From reliable sources, the writer has learned of herds of one to two hundred cows showing $90 \%$ reacting. Averages including results from small herds are lower.) In New York State figures compiled from results of testing under the supervision of the Commissioner of Agriculture, and from tests by private practitioners, show $32 \%$ of the cows reacting. The disease was found in $61 \%$ of the herds tested (22).) Recent tests of cows supplying Washington, D. C., show $18.6 \%$ reacting.) These figures are lower than true conditions, for the cows tested were either in herds where efforts to eradicate the disease were in progress, or where the owner had no suspicion of serious trouble. The writer encountered practically the same figures in Berkeley, Cal., among herds where the owners did not refuse permission to test. Among 1022 cows in 22 herds in California, Dr. Haring and the writer have found $31.9 \%$ reacting. (Eighty-two per cent. of the herds were found to contain infected animals.) The figures are compiled only from results of whole herds, tested for the first time. Of 71 cows pastured on vacant lots in Berkeley, only $8 \%$ reacted (55). These figures concerning the prevalence of tuberculosis among cattle in California were derived from results obtained largely in herds in the San Francisco Bay region furnishing city milk supply. It is not permissible to generalize from them regarding the prevalence of the disease among cattle elsewhere, in herds managed differently. 
Contamination of milk by tubercle bacilli. The channels by which tubercle bacilli are eliminated from the body of the tubercular cow, have been carefully studied. The elimination of tubercle bacilli from the mouth, in the saliva, is not of direct importance in the contamination of milk. When the uterus is involved, or the urine contains tubercle bacilli, the probability of the infection of the milk is great. The tubercular udder, whether diseased so badly as to permit detection or so slightly as to escape detection by plysical examination, gives off tubercle bacilli. In this connection, the conclusions of Mohler (19) bearing on the point at issue, are quoted:

"From the results of the experinents conducted in this laboratory as well as from the n1ajority of sinilar investigations quoted in this article, the following conclusions regarding the infectiousness of nilk from tuberculous cows seem justifiable:

“1. The tubercle bacillus inay be demonstrated in milk from tuberculous cows when the udders show no perceptible evidence of the disease, either macroscopically or microscopically.

“2. The bacillus of tuberculosis 111ay be excreter from such an udder in sufficient numbers to produce infection in experimental animals both by ingestion and inoculation.

" 3 . That in cows suffering from tuberculosis the udder may, therefore, become infected at any monent.

"4. The presence of the tubercle bacillus in the milk of tuberculous cows is not constant, but varies from day to day.

" 5. Cows secreting virulent milk may be affected witl tuberculosis to a degree that can be detected only by the tuberculin test.

"6. The physical exannination or general appearance of the cow cannot foretell the infectiveness of the milk.

" 7 . The milk of all cows which have reacted to the tuberculin test should be considered as suspicious, and should be subjected to sterilization before using.

" 8 . Still better, tuberculous cows should not be used for general dairy purposes."

Ostertag (28) has reached contradictory conclusions, but in view of all the facts available at present, the conditions encountered by him must be regarded as unusual. (It has been shown that an udder so slightly diseased as to be detected only on microscopic examination of the tissues, yielded tubercle bacilli (29). The difficulty in determining exactly when an udder is 
tubercular complicates the matter of determining whether or not tubercle bacilli are found in milk from a healthy udder. In the light of facts recently brought to attention, the discussion of this matter of the udder in its relations to milk inspection is not very profitable.)

The manure of cattle contaninated with tubercle bacilli is regarded as an important source of tubercle bacilli in milk. Reacting tuberculous dairy cows that retain the appearance of health, may actively expel tubercle bacilli in the feces $(41,42$, $43,46)$. A very snuall percentage of such cases in a herd could bring about a very extensive infection of the milk. Among the possible sources of the bacilli, understood at present, are sputum swallowed, and open tubercular lesions of the intestines. Feces constitute the most common contanination of milk as demonstrated by observation of dairy practice, and by the microscopic examination of milk sediments. The presence of tubercle bacilli in human feces in early cases has been noted and suggested as a means for the early diagnosis of the disease (51).

Tubercle bacilli in market milk. Anderson (1) found in Washington, D. C., that $6.72 \%$ of 223 samples examined contained tubercle bacilli. The results analyzed according to the source of the samples showed that about $11 \%$ of the dairies whose milk was examined showed tubercle bacilli. His methods were such that he believes the results understate the true conditions.

Schroeder (43) refers to the examination of 350 samples of milk in Washington by different workers with the result that about 5.5\% showed tubercle bacilli. About one dealer out of every ten was intermittently selling tuberculous milk. Hess (9) examined 107 samples of milk in New York and found tubercle bacilli in $16 \%$ of the samples. Trask (Ref. 33, Chap. III) has collected the results of the work on tubercle bacilli in milk, done by a large number of investigators.

- Human and bovine types of tubercle bacilli. (The original ideas of the complete unity of tuberculosis in cattle and in man were based upon the identity of the lesions in gross and microscopic appearance. fUp to 1896 , the identity of the 
tubercle bacilli in the two branches of the disease was not questioned. Then Theobald Snith pointed out certain differences in morphology, cultural characteristics and virulence regarded as characteristic of the organism in man and bovines $(47,48)$. That these differences are ustrally observed, is a fact that has received very. wide confirmation.

Views of Koch. In 1901 (13) and 1902 (14), Koch very carefully reviewed the grounds for the belief that bovine tuberculosis is transmitted to man, and reached the conclusion that it is not worth while to combat bovine tuberculosis in the interest of the public health. Koch's paper raised an extraordinary storm of protest, and likewise stimulated the study of the problem along lines suggested by his arguments.) $\mathrm{He}$ pointed out very clearly and conclusively the essential weat ness of the evidence frequently accepted as proof of the transmission of tuberculosis to man. The very wide prevalence of human tuberculosis makes it very difficult to establish the absence of human infection in cases where cattle are suspected as the source. He laid down certain conditions that must be satisfied before transmission would be admitted as proven, and these dicta are so stringent that it would be very difficult to find any case conforming to them.

It has been observed by Koch that milk-borne tuberculosis does not correspond to the other milk-borne diseases in the matter of the sudden explosive occurrence of cases among those consuming the milk. The known peculiarities of tuberculosis, such as its deliberate onset, and especially the conception of latency of infection introduced by von Behring (52), rather impair the value of the point as an argument against the transmission of tuberculosis by milk.

Bovine tubercle bacilli in man. Koch pointed out that the recognition of bovine and human types of tubercle bacilli gave a sound basis for determining the source of the disease in human cases. It is along this line that the most conclusive evidence of the transmission of the disease has been obtained. The literature shows between forty and fifty cases in which bovine tubercle bacilli have been isolated from infants and children. This was conceded in 1907 by Theobald Smith (49), 
whose attitude is eonservative and eritical. In 1908 he stated : "and it has been found that perhaps half of certain kinds of tuberculosis in children, such as those of the glands of the neck and abdomen, are due to infection from milk." (50)

/Insufficient work has been done to determine the percentage of human tuberculosis caused by bovine tuberculosis. The British Royal Commission found the bovine type 14 times in 60 cases of human tubereulosis investigated by it (5). The significant fact is that here is indisputable evidence to satisfy the most conservative that tuberculosis is transmitted from cattle to man.)

Intermediate types of tubercle bacilli. Some observers believe that the study of a series of tubercle cultures reveals intermediate types varying from the extremes exhibited by human and bovine cultures $(3,7,20,43)$. These intermediates have been observed in both cattle and man. The observation has led to the conclusion that certain characters of the tubercle organisms are exceedingly variable. For instance, a bovine strain in a child might after a time be modified by environment so much as to disguise its original source. If this point of view is taken, bacteriological distinctions - the only ones-between tuberculosis in cattle and man break down, and the importance conceded to bovine tuberculosis in connection with the public health is consequently increased.

Channels of infection. Alimentary infection was formerly thought to give rise necessarily to primary tuberculosis in the mesenteric lymph nodes. The rare occurrence of this condition was used by Koch as an argument to prove that tuberculosis in children does not frequently originate from milk. Experimental work with reference to this point has shown that the primary lesion in animals need not necessarily occur in a mesenteric lymph node. Tubercle bacilli from the intestinal tract may travel to the lungs via lymph node, thoracic duct and blood, causing the primary lesion in the capillaries of the lung or elsewhere (30). It is also believed that infection may enter through the tonsils and cause tubercular involvement of organs anterior to the diaphragm without ever traversing the abdominal organs. There is a growing belief based on 
the work in meat inspection, that alimentary infection plays a very important part in the infection of cattle and hogs. Such observations have been made the basis of an assault on the older theory of exclusive inhalation infection of the lung, and tend to exalt the importance of alimentary infection.

International Congress of 1908. At the International Congress on Tuberculosis at Washington in 1908, Koch stated that he believed bovine tuberculosis to constitute a minor source of tuberculosis in man. He regarded pulmonary tuberculosis (phthisis) as the cause of eleven-twelfths of the deaths from tuberculosis and he was not convinced that the bovine type of tubercle bacillus has been shown to produce that type of tuberculosis in man. He disparaged the importance of the cases in which the borine type of bacilli have been found in glands on the ground that glandular tuberculosis, in comparison with pulmonary tuberculosis, is a minor cause of fatality. On the point concerning the frequency of primary abdominal and cervical tuberculosis, the belief was held by many of the delegates that these types of tuberculosis are much more frequent and important than believed by Koch (6).

The portion of the resolutions of the Congress bearing on bovine tuberculosis is as follows:

“ 3 . *** Again, the utmost efforts should be continued in the struggle ogainst tuberculosis to prevent conveyance from man of tuberculous infection as the most inportant cause of the disease. Further, preventive measures must be continued against bovine tuberculosis, and the possibility. of the propagation of this to man should be recognized.", (31)

Tuberculosis in Japan. The tendency to regard bovine tuberculosis as the chief source of tuberculosis in human beings, is counteracted by certain evidence (12).

In Japan very little cow's milk is used for food, the average amount consumed daily per capita being only $2.825 \mathrm{cc}$. Especially is it rarely employed as food for children. Human tuberculosis is as frequent in Japan as in Europe and America. There the disease in man dates back to the earliest chronicles. Tuberculosis occurs only in foreign cows and their crosses with native cattle. Pure native cattle are relatively immune and 
no tuberculosis was known among Japanese cattle until the introduction of foreign stock about thirty-five years ago.

Present status of controversy. That tuberculosis may be transmitted from cattle to the human being, is an accepted fact not even denied by Koch. The differences of opinion concern the extent to which it occurs, and these in turn depend upon the conception of the characters that may be accepted as defining an organism of bovine origin. On the whole, the belief is that tuberculosis in cattle constitutes a minor source of tuberculosis in man.

Protection of the milk supply. The situation warrants the enforcement of firm, effective measures for the protection of the milk supply. The proven facts excite both disgust and apprehension on the part of the consumer. To correct such conditions is a very legitimate function of food inspection service. No question is raised as to the propriety of condemning carcasses for generalized tuberculosis, even though most meat is practically safe when cooked. The ground for condemnation is the abhorrence and fear of consuming infectious tubercular material. The same undesirable qualities are possessed by milk of tubercular cows, only worse, for it is not the practice to cook milk.

Certain physicians show a tendency to avoid agitation concerning cattle, the minor source of tuberculosis, for fear of distracting popular attention from the main source of infectiontubercular human beings. This, perhaps, is justifiable in so far as the attitude relates to the spending of money. There is no question but that money for fighting tuberculosis of man could be more profitably spent than in attempts to eradicate tuberculosis of cattle by slaughtering animals and indemnifying the owners. This is an economic matter primarily.

Measures against bovine tuberculosis. A number of circumstances combine to make it most difficult to protect effectually the milk supply from the germs of tuberculosis. (The wide prevalence of tuberculosis among cattle raises obstactes in the way of expense incurred to the dairymen. A great many attempts have been made to control the disease both in the interest of the public health and as a purely economic measure. 
In most cases great expense has been incurred by the dairymen, with little permanent benefit. Tuberculosis in general has kept pace with the efforts directed against it, and in only a few states can it be claimed that substantial progress is being made in its eradication. Dairymen have, for almost a generation, been harassed by agitation over the stubject and their attitude towards public health measures is one of indifference or open hostility. City milk supply is derived from such scattered sources that effective administration is difficult. Then, too, the individual cows comprising the herds are constantly changing as they dry off and are replaced by fresh cows. Coupled with this it should be noted that the majority of dairymen persistently ignore precautions against introducing the disease. Under these conditions the temptation is great to resort to bribery in some cases, or to legal measures for the purpose of invalidating the ordinance. The circumstances are such as to encourage laxity in the enforcement of tuberculin test ordinances. A sharp distinction should be drawn between the meanings of the expressions "in force" and "enforced" as applied to an ordinance.

Physical examination. While some advanced cases of tuberculosis can be recogniized by physical examination, such an examination will reveal but a small percentage of the cases capable of disseminating infection.

The idea of inspecting dairy herds by physical examination alone is based upon the belief that a physical examination is capable of indicating the seriously diseased animals. The evidence accumulated from post-mortem examinations of dairy cattle, and from the bacteriological examination of feces, controverts the truth of the assumption. If a physical examination is to be of use, it must be so searching as to permit the detection of all those animals having open lesions in the respiratory and alimentary tracts. Such results are not obtainable. Among the dangerously tubercular animals may be found at postmortem examination the best looking cows in a herd. The condition of flesh of an animal is worthless as a guide. The good dairy cow certainly is emaciated at times, and this in conjunction with an old coat of hair gives a miserable appear- 
ance. Under the circunnstances, emaciation as a symptom of tuberculosis cannot be given very heavy consideration. Auscultation and percussion of the lungs do not yield the results that might be expected, and the same may be said of palpation of the superficial lymph glands. Neither the lungs nor accessible lymph glands are necessarily involved in advanced cases.

Emphasis has been laid upon the value of detecting the tubercular udder, as if it were a very important factor in the contamination of milk. As a matter of fact, the development of tuberculosis in the udder to a degree that would attract attention is very rare. Smith (49) believes that roughly speaking the udder becomes tuberculous through metastasis in perhaps $1 \%$ of tubercular cows. Müller (27) states that $1.62 \%$ of all cows slaughtered in Germany show tuberculosis of the udder. Mammitis, associated with steptococci, is very common and causes indurated areas in the udder that raise insurmountable difficulties in the differential diagnosis by physical signs. The bacteriological examination of samples of milk from the suspected udder is the only reliable means for identifying tuberculosis of the udder.

In the discussion of the tuberculosis problem the idea is sometimes implied that the detection and removal of the worst animals from a herd will effect some measure of improvement in diminishing the disease. Such a procedure does not appreciably diminish the opportunity for the further spread of infection and certainly does not benefit the large number already slightly affected. Physical examination and removal of the condemned animals anticipates by a considerable period the natural breaking down from the disease and results in the removal of some others less seriously diseased but which happen to be easily detected. It results in no permanent improvement along the line of extinguishing the infection.

The writer's personal experience in physical examination of dairy herds for tuberculosis has been most unsatisfactory. About 300 cows supplying a town with milk were examined once in each of two successive years. Cows showing definite unmistakable physical signs of tuberculosis, warranting slaugh- 
ter, were not found, but three excited strong suspicion. The dairymen either in accordance with regular practice or on account of the moral effect of the inspection, had removed the cows that persistently coughed. In the third year, the tuberculin test revealed the fact that $30 \%$ of the cows were tubercular. During work in another town in a group of 64 tubercular cows, only 9 showed physical signs of tuberculosis. The writer does not feel that he is making a confession of discreditable incompetency, for his experience is not unusual. In one instance, a recognized expert on bovine tuberculosis examined 378 reacting cows and was able to recognize only 21 as tubercular by means of physical examination.

The idea of the efficacy of physical examination to prevent the presence of tubercle bacilli. in milk persistently crops out in the discussion of methods of milk inspection. As late as May, 1907, a commission of physicians made the following recommendations to the Mayor of New York (10):

"The Commission believes that the essential requirement is to secure from the farm a safe, clean milk.

“'Tuberculosis. - The risk of transmitting tuberculosis through milk from cows to man is very slight, unless the disease in the cow is in an advanced form or is present in the udder. Fiven this slight risk is considerably lessened when such milk is mixed, as it generally is, with that of healthy cows before it is sold. We believe that this danger has been greatly overestimated in the public mind and that it can best be met by systematic inspection and condemnation of cows revealing tuberculosis on physical examination. Certain legislation regarding tuberculosis in cattle now being contemplated at Albany has been carefully considered, and the Commission believes that if suitable legislation can be secured with adequate appropriations for the enforcement of the same, our milk supply in this respect coming from the State of New York will be suitably safeguarded. Such legislation should provide for notification of city authorities of the existence of disease, which may be transmitted through milk, occurring in the cows or in the families or the persons of those handling milk.",

- Municipal activity on the tuberculosis problem will certainly accomplish nothing worth while if carried on along the lines recommended above. The statements are apparently based on the faulty assumption that a physical examination will reveal cows affected with tuberculosis in an advanced form, and that 
such are the only ones disseminating large numbers of tubercle bacilli. The idea is controverted by a mass of evidence too weighty to be thus ignored. The Commission betrays a certain amount of hesitancy in regard to measures against bovine tuberculosis, for elsewhere in the report the following recommendation is made:

"Pasteurization. - Notwithstanding after all safeguards that may be imposed by education and otherwise, there will be cases in which unsafe 111ilk will be produced or offered for sale, and all such milk must be judgerl on its merits. The Connmission, therefore, recommends that the Board of Health should, according to circunstances, require efficient sterilization or pasteurization of all 111ilk which it finds unsafe for consumption as raw $111 \mathrm{k}$, on account of a suspicion of the presence of tuberculosis or other disease in the cows or unsanitary conditions of the dairy or a persistent high bacterial content. But in every instance nilk so heated slould be rapidly cooled to at least $40^{\circ} \mathrm{F}$., and be put after sterilization or pasteurization, into sterilized containers under aseptic precautions. The pasteurization of 111ilk should be done only a few hours before delivery to the consumer, and the container slould be marked with the time and date of pasteurization and the degree and cluration of temperature employed for the purpose."

Tuberculin test. (The tuberculin test is the only available means for the detection of tuberculosis in cattle.) Tuberculin is a sterile liquid product containing a concentrated extract of tubercle bacilli. The subcutaneous injection of a properly standardized close of tuberculin will induce a rise of temperature in a tubercular animal in which the disease is active, but will have no effect upon a non-tubercular animal. The test is indispensable in the control of the disease by revealing the animals in every stage of the disease beyond the incubation period. (The test does not reveal the extent of the disease and hence is of no value in discriminating between tubercular animals disseminating infection and those not.) The information obtained furnishes the means of separating the healthy from the diseased. In view of the fact that tuberculosis so frequently develops in the animal rapidly, any tubercular animal in a herd is poteip tially if not actually dangerous. It is a most difficult matter to convince the average man upon this point. The number of animals reacting is oftentimes surprisingly large when the general appearance of the herd is considered. Among those 
reacting there may be the finest appearing and best producing cows in the herd. A post-mortem examination, revealing a small lesion, does not convince the layman that the slaughter was justified.

New tests for tuberculosis. Of late, considerable attention has been paid to certain modifications of the method of applying the tuberculin test (25). Among these are the intradermo (26) and ophthalmo (56) tests. Their claim to attention is based on simplicity but they are as yet in the experimental stage.

Stable sanitation and tuberculosis. Good sanitary conditions, good ventilation, reasonable exercise, good climate, good food and general well being are in high repute as measures for restricting and preventing tuberculosis in man. In some quarters there is a tendency to assume that the bovine, surrounded by conditions that are by assumption rated as correspondingly good, will be in a meastre protected from bovine tuberculosis. A true parallel does not exist, for the conditions favoring the spread of bovine tuberculosis are such that the best of stables in the best of climates or even no stable at all, will not prevent the spread of the disease (54). Baker (4) has produced some very striking evidence on the point drawn from statistics concerning cattle slaughtered under Federal inspection in San Francisco.

Tuberculin test ordinances. The object of municipal legislation is not primarily the eradication of bovine tuberculosis, but rather to ensure a pure milk supply. The legislation, therefore, need go no farther than to ensure the exclusion of milk of diseased animals by requiring that all cows pass the tuberculin test and a physical examination. Since the milk supply comes largely from without the borders of the city, it would be difficult, both legally and practically, to go farther than this. The dairyman is thus at liberty to accept the conditions imposed for a license by the city, or to sell his milk elsewhere. The plan involves no compulsory interference with property rights and does not necessarily contribute to the reduction of bovine tuberculosis beyond the dairies immediately affected.

Tuberculin test ordinances are in force in a number of American cities. Probably Minnesota heads the list of states in the 
number of cities having the test. The list as given in the Minnesota exhibit at the International Congress on Tuberculosis, Washington, 1908, is as follows: Minneapolis, St. Paul, St. Cloud, Alexandria, Duluth, Mankato, Litchfield, Willmar, Albert Lea and Winona. Montclair, N. J., is at present the scene of a legal struggle between the dairymen and the Board of Health, on the matter of the enforcement of a tuberculin test ordinance. The Board of Health of Berkeley, Cal., has attempted to enforce two different tuberculin test ordinances but has been enjoined by the courts from doing so in each case.

The complete, impartial enforcement of an ordinance prohibiting the sale of milk from reacting cattle raises a host of difficulties occasioned by the wide prevalence of tuberculosis. The condemnation of, say, $25 \%$ of the cows supplying a city, throws all the producers into the market for cows. Those for sale are those that have just reacted. During the excitement of the enforcement of the tuberculin test ordinance, cow owners will not sell cows subject to the test. Compliance with the ordinance means reduction of the output of nillk. Producers will refuse to sell to the distributors in the city, and will market the milk elsewhere. The dairies that at present are able to comply with a tuberculin test ordinance, represent an insignificant per cent. of the milk supply of our larger cities.

Clean herds the goal. In isolated instances, the complete enforcement of a tuberculin test ordinance is practicable, and this should be the end towards which efforts everywhere should be directed. The difficulties of the problem presented by the larger cities must be met by a scheme that will permit gradual improvement. Even with a bountiful supply of healthy cows available, and with the cordial co-operation of the owners of herds, the work of testing the herds and eradicating tuberculosis is a tremendous task and would take years. The continuance of present conditions must be discouraged, the public health must be protected, and at the same time the measures enforced must not disrupt the milk business.

The Washington plan. The most practicable scheme that has been suggested is the compulsory pasteurization of all milk produced from cows that have not passed the tuberculin 
test. The suggestion has been made by a Milk Conference appointed by the Commissioners of the Inistrict of Columbia (40). The members of the conference represented the various Federal departments interested in the subject, together with the dairymen. The conference recommends the classification of milk into three grades, as follows :

\section{"Class 1. Certified milk."}

This grade represents the highest class of milk, ordinarily certified by medical societies. The tuberculin test and a bacterial count of under 10,000 per cc., are among the requirements. (See Chap. IX.)

\section{"Class 2. Inspected milk.",}

This is a lower grade of milk, produced from tested cows, and differing from the former, chiefly, in that the conditions under which the milk is produced need not be equal to those of dairies in Class 1. The bacterial count shall not be more than 100,000 per cc.

"Class 3. Pasteurized milk. Milk from dairies not able to comply with the requirements specified for the production of milk of classes 1 and 2 is to be pasteurized before being sold, and must be sold under the designation 'pasteurized milk'. Milk for pasteurization slall be kept at all times at a temperature not exceeding $60^{\circ} \mathrm{F}$. while in transit from the dairy farm to the pasteurization plant, and milk after pasteurization shall be placed in sterilized retainers and delivered to the consumer at a temperature not exceeding $50^{\circ} \mathrm{F}$. All milk of an unknown origin shall be placed in class 3 and subjected to clarification and pasteurization. No cow in any way unfit for the production of milk for use by man, as determined upon plysical examination by an authorized veterinarian, and no cow suffering from a communicable disease, except as specified below, shall be permitted to remain on any dairy farm on which milk of class 3 is produced, except that cows which upon physical examinattion do not show plysical signs of tuberculosis may be included in dairy herds supplying milk of this class, although they may have reacted to the tuberculin test.

"This milk is to be clarified and pasteurized at central pasteurization plants, which shall be under the personal supervision of an officer or officers of the liealth department. These pasteurization plants may be provided either by private enterprise or by the District Government, and shall be located within the city of Washington.',

Elsewhere in the report, the conference makes the following recommendations regarding tuberculosis : 
"Identification of dairy cattle. That all cows on dairy farms producing milk for the District of Columbia be tagged, tattooed, or otherwise marked for purposes of identification.

"Tuberculin testing or pasteurization required. That all milk produced for use in the I)istrict of Columbia sliall either come from cattle free from tuberculosis as shown by the tuberculin test, which tuberculin test shall be repeated at least once every year, or be subjected to pasteurization under the supervision of the health department in case the herd is not tuberculin tested.

" New dairy cattle to be tuberculin tested. That hereafter no addition shall be made to any herd producing milk for use in the District of Columbia, whether such herd has or has not been tuberculin tested, unless the cattle so alded have been tested with tuberculin and found to be free from tuberculosis.

"New licentiates to have herds tuberculin tested. That hereafter no license shall be granted to produce milk for use in the District of Colunibia unless the herd by which such milk is to be produced has been found by the tuberculin test to be free from tuberculosis.",

The compulsory pasteurization of all the milk supply of a city will be attended with difficulties, but these are slight as compared with those associated with the enforcement of a tuberculin test ordinance. Chicago has adopted the scheme of enforcing the tuberculin test, with the alternative of pasteurizing the milk.

Test by city official. The testing of cattle is best carried on by a veterinarian employed by the municipality. It is highly desirable that he be paid well enough to warrant devoting his time exclusively to the work in hand. The requirements of the work, even in a small city, call for the undivided attention of one man for milk inspection and tuberculin testing. PThere should be a decided increase in the budget allotments of municipalities for the proper enforcement of tuberculin test ordinances. The important requirement is that the inspector should not be engaged in private practice and consequently dependent upon the good will of the dairymen. The customary system of paying a moderate salary for a portion of the timeof a practicing veterinarian is detrimental to efficient work for the municipality. If the application of the tuberculin test is made optional with the veterinarian, the test will certainly not be made. The veterinarian can not do his full duty without 
giving offense that will eventually destroy his practice. Private practice and efficient municipal work are incompatible.

The man carrying on the testing must be proof against the corruption to which he will be continually exposed. His professional skill and judgment will be criticized by the dairymen and by jealous unprofessional aspirants for his "job." The officials or board to whom he is responsible must entertain unswerving faith in his qualifications, else they will waver in the face of the storm of protest and denumciation that will emanate from the dairymen.

Test by any licensed zeterinarian. In some of the larger municipalities the ordinance may require the dairyman to produce a report from any qualified veterinarian, but such a provision is an invitation to fraud and dishonesty. Under such conditions the effectiveness of a tuberculin test ordinance is likely to be entirely destroyed.

In Berkeley, Cal., an ordinance was passed (Appendix A) permitting any licensed veterinarian to make tuberculin tests, but containing provision for subsequent tests by the representative of the health officer in case the latter doubted the accuracy of the reports. That this feature was undesirable was fully recognized but it would have been quite out of the question to have obtained the appointment of a city veterinarian to do all the work. The first attempt to exercise the provision in regard to retesting resulted in litigation and the invalidation of the ordinance on a legal technicality not concerning the test.

The Chicago tuberculin test ordinance is weak on this point, for in the rules regarding the tuberculin testing of cows any licensed graduate veterinarian is permitted to do the work (Appendix B). The Duluth ordinance is stronger in this feature (Appendix C).

Milk contracts. In the larger cities most of the retailers are supplied by the producers or others, under the terms of yearly contracts. Unless the health regulations have been very rigidly enforced, these contracts are not liable to contain clauses providing that the milk conform to health requirements. Any radical-or sudden change in the law is apt to 
make trouble between the retailer and the producer. Due warning obviates the difficulty.

Application of the tuberculin test. In the earlier days when the tuberculin test was in the experimental stage, it was customary to take a series of normal temperatures of the cows during the whole day preceding the injection of tuberculin. The data thus obtained permitted the plotting of temperatures, before and after injection, in a most convincing way. The confinement of the cows for the day for taking these temperatures interferes greatly with the secretion of milk and entails much extra work. These circumstances furnish a strong incentive for decreasing the number of these "normal" temperatures. In practice, veterinarians take about two temperatures before injecting, merely to establish the fact that the animal is not in a febrile condition.

Temporary numbers. The identification of the cows during the test is satisfactorily accomplished by painting numbers on the rump with green paint. The numbers will, in a few cases, be smudged before drying and the difficulty from this may be obviated by numbering all the cows in duplicate.

Facilitating observations of temperatures. The observation of temperatures may be expedited by the use of several thermometers simultaneously. When more than one thermometer is used the risk of breakage necessitates attaching the thermometer to the cow by a string. Special ring top veterinary thermometers on the market facilitate tying a string to the thermometer. The human clinical thermometer may have a string attached to it through the medium of a rubber band firmly wrapped around the top. There is attached to the other end of a six-inch string a pair of dog-tooth clasps. When the thermometer is inserted in the rectum, the clasp is attached either to a firm concretion of manure on the hair or to the skin, which latter however is liable to cause kicking.

Nervous cows will greatly delay the work by resisting the insertion of the thermometer. This may be obviated by enlisting the services of one of the milkers to stand at one side and pat the cow on the back. Quiet, businesslike work, with the minimum of delay and excitement of the cow, must always be kept in mind. 
The services of at least one non-professional assistant, besides the stable-man, will be found very useful. He could be employed to insert thermometers and to record the temperatures on the blank provided for the purpose. The responsible work of reading the thermometers can thus be carried on rapidly by the veterinarian making the test. Fig. 10 shows a

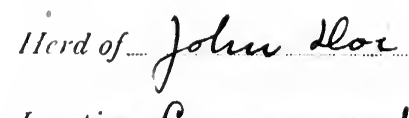

Location

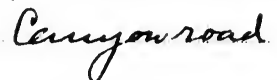

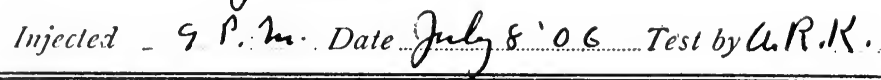

\begin{tabular}{|c|c|c|c|c|c|c|c|c|c|}
\hline \multirow[t]{2}{*}{ No } & \multicolumn{2}{|c|}{$\begin{array}{c}P 2 m \\
\text { Before }\end{array}$} & \multicolumn{5}{|c|}{ remperatures $P . n_{n}$} & \multirow{2}{*}{ Remark: } & \\
\hline & 2 & $8^{\circ}$ & 1 & 4 & 11 & 1 & 3 & & \\
\hline 1 & 166 & 1.5 & 1.3 & 1,3 & 2.9 & 1.8 & 1.4 & asp & 7 \\
\hline 2 & 1.4 & 2,2 & 0.3 & 1.2 & 2.1 & 1.7 & 1.0 & w & 8 \\
\hline 3 & 1.2 & 1,3 & (i.) & 1.4 & 2.1 & 0.8 & 1.1 & $w_{h}$. & 9 \\
\hline 4 & 1.6 & 2.1 & 1.8 & 3.0 & 6.5 & 5.8 & 3.6 & Cond & \\
\hline 3. & 1.4 & 2.2 & 3.0 & 5.5 & 5.6 & 4.5 & 4.2 & Cond. & \\
\hline 6 & 1.2 & 1.5 & 0.4 & 0.5 & 2.7 & 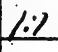 & 1.9 & cyp: & 10 \\
\hline
\end{tabular}

Fig. 10. Blank for recording temperatures.

convenient blank for recording temperatures. It will be noted that the temperatures are written in an abbreviated form. For instance $101.6^{\circ}$ is recorded as 1.6 , etc. The blank as used is three inches broad and about seven inches long. The width permits folding the records and filing them away with the identification cards mentioned on page 81 . The significance of the numbers in the column at the extreme right is described gin page 82 .

After the temperature is read, the thermometer is inserted in a pot of vaseline until needed for use next time. If there is no convenient ledge at the rear of the cows, a light portable box, about a yard high, forms a convenient stand for the vaseline and thermometers. 
Injcction with tuberculin. The tuberculin is injected during the evening at a time to allow an interval of ten hours before the cows are milked the next morning. The insertion of the hypodermic needle is accomplished with greatest facility and least danger to the operator by leaning on the withers of the cow and injecting upon the side opposite to the operator. Asepsis is practically accomplished by dipping the needle in concentrated carbolic acid each time before use.

Temperatures after injection. Temperatures are taken every two hours from the 10th to the 16th hours, and later in the case of those animals showing an elevation to $103.5^{\circ}$ at the 16th hour. It is frequently recommended that the temperatures be taken from the 8 th to the 20 th hour. Such requirements impose serious hardship on the dairyman by the loss of milk, due to the anmoyance of the cows. For all practical purposes the shorter period of taking temperatures is sufficient to reveal a reaction. The animals should be under as quiet and natural conditions as possible during the test. It is usually desirable to allow them liberty, with access to drinking water, between the 12th and 14th hours.

Interpretation of temperatures. A rise of $1.5^{\circ} \mathrm{F}$. above the normal, if gradual and distributed over a period of several hours, followed by a gradual decrease, constitutes a reaction. Fig. 10 shows two typical tuberculin reactions. A brief upward fluctuation of the temperature is not regarded as significant. In the case of the ordinary well marked reactions, it is not considered necessary to continue taking temperatures after the fastigium has been passed. Animals exhibiting questionable reactions should be retested one month later, injected with three times the usual dose of tuberculin.

It is the rule not to condemn animals showing a rise of temperature when in oestrum or when within six weeks of parturition. It is well to inject all such animals in a herd and to retest later those exhibiting a fever.

Limitations of tuberculin test. The tuberculin test does not reveal facts concerning the extent of disease. Hence in a small percentage of reacting cases no lesions can be found in postmortem, probably due to the fact that the lesion is too small 
to detect. Animals in the advanced stages sometimes fail to react but the existence of tuberculosis in such cases should be readily detected from the physical appearance of the animal. There are at least two conditions under which an animal once failing to react may at a later time react to the test. During the incubation period of the disease, that is, when the tubercle bacilli are within the body but before a lesion is developed, no reaction will occur. Later, the animal will respond. Thoroughly encapsulated lesions will not permit response to tuberculin, but later may become active and cause reaction. 'These facts are of great significance in pointing to the necessity of frequent testing.

Fraud. Dishonesty on the part of the attendants of the cattle may be responsible for erroneous results of a test. It is an important fact that a tubercular animal will not give two reactions in succession. Thus a dairyman may inject his herd a few days previous to an unwelcome expected test, and thereby wholly mislead the man making the later test. Tuberculin is readily purchased upon the market but its sale should be subject to restrictions. Febrifuge drugs are said to be also used to defeat the tuberculin test, by counteracting the febrile conditions. Frauds may be extensively practiced, but unexpected tests will eventually expose the dishonest practice.

Permanent identification of animals. The thorough identification' of the animals is under most conditions a necessary
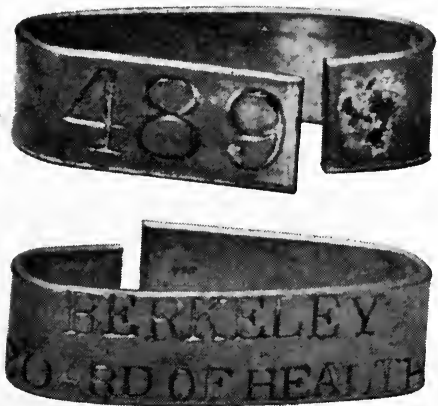

Fig. 11. Ear-tag for marking cattle. matter. The liability of frand is very great when any compulsion attends the application of the test or the subsequent disposition of the reacting animals. A useful means of identification is afforded by metal ear-tags, numbered serially and bearing a legend identifying the official body responsible for the test, as for instance, a board of health or a milk commission. Fig. 11 
shows ear-tags as described. The characters borne by the tag are stamped on at the factory and consequently may not be readily imitated for fraudulent purposes. Furthermore, duplication of numbers will not occur. The ear-tags should be affixed after a test to all animals whether they have reacted or not. It is of no particular value to tag only non-reactors, since after subsequent exposure of the animal to infection the tag gives no guarantee of freedom from tuberculosis. In one case where such a practice was in vogue, it was observed that dairymen would willingly purchase a tagged cow without further guarantee of health. Furthermore, owners have pointed out the death from tuberculosis of a tagged animal as an evidence of the unreliability of the test. It is not well to encourage the idea that an ear-tag is a fetish against tubercular infection. It is quite possible that ear-tags may be lost and also that ear-tags may be transferred to other animals for fraudulent purposes. An absolutely safe identification, then, requires further safeguards. For this purpose the writer devised a 3 by 5 -inch card printed with the outline of a cow and blanks for important data (53).

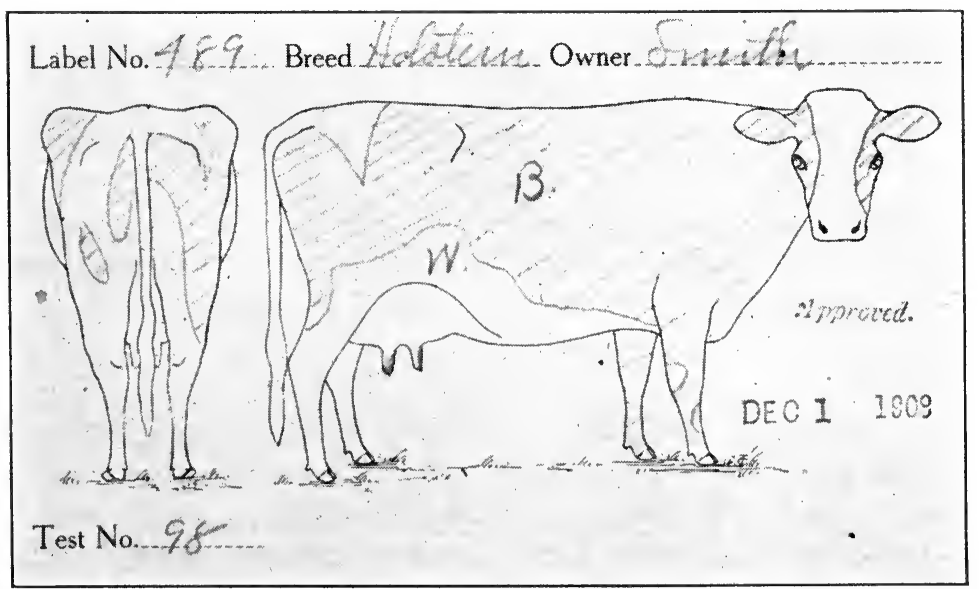

Fig. 12. Card employed by the writer for the identification of cows. 
Fig. 12 shows such a card filled out with descriptive matter, etc. The amount of sketching required is very small. The color of the animal, together with some distinctive peculiarity, may be all that is necessary to record for purposes of identification. Mutilations of the ears or the character and location of brands may be readily indicated by a stroke of the pencil. The insertion of the temporary and permanent numbers on both the card and the temperature blank makes it possible to keep an accurate record of the test history of every cow in a herd. Such cards are carefully filed for use in subsequent inspection of the herd. For instance, when rules or ordinances require the testing of all animals admitted to a herd, the identification system gives the inspector full knowledge of the facts. The presence of a condemned animal, minus the ear-tag, could be proven by comparison of the markings of the cow with the sketches. Moak has derised a slight modification of the identification card as shown in Fig. 13. He is enabled to file away the tuberculin test record on the card, which is a feature particularly useful when a few cows are tested at a time.

Disposal of tubercular animals. In some states it may be possible for dairymen to take advantage of partial indemnification offered by the state to the owners of condemned animals. In the early days of effort to exterminate bovine tuberculosis, many states adopted a policy of at least partially indemnifying the owner for losses sustained in destroying animals. This method in general failed to accomplish permanent benefit, because sufficient funds were not appropriated to make the work as thorough as the circumstances demanded. The right of an owner of a tubercular animal to demand indeminification for the loss occasioned by its slanghter on the ground of the benefit to the public health, seems to be an open question. The principle certainly is not recognized when carcasses are condemned in abattoirs nor is a man in quarantine for the public good compensated therefor. The owner of a herd, in tolerating the existence of the disease, is quite as responsible for the losses from it as is the public. The practice of indemnification certainly facilitates work in combating tuberculosis. 


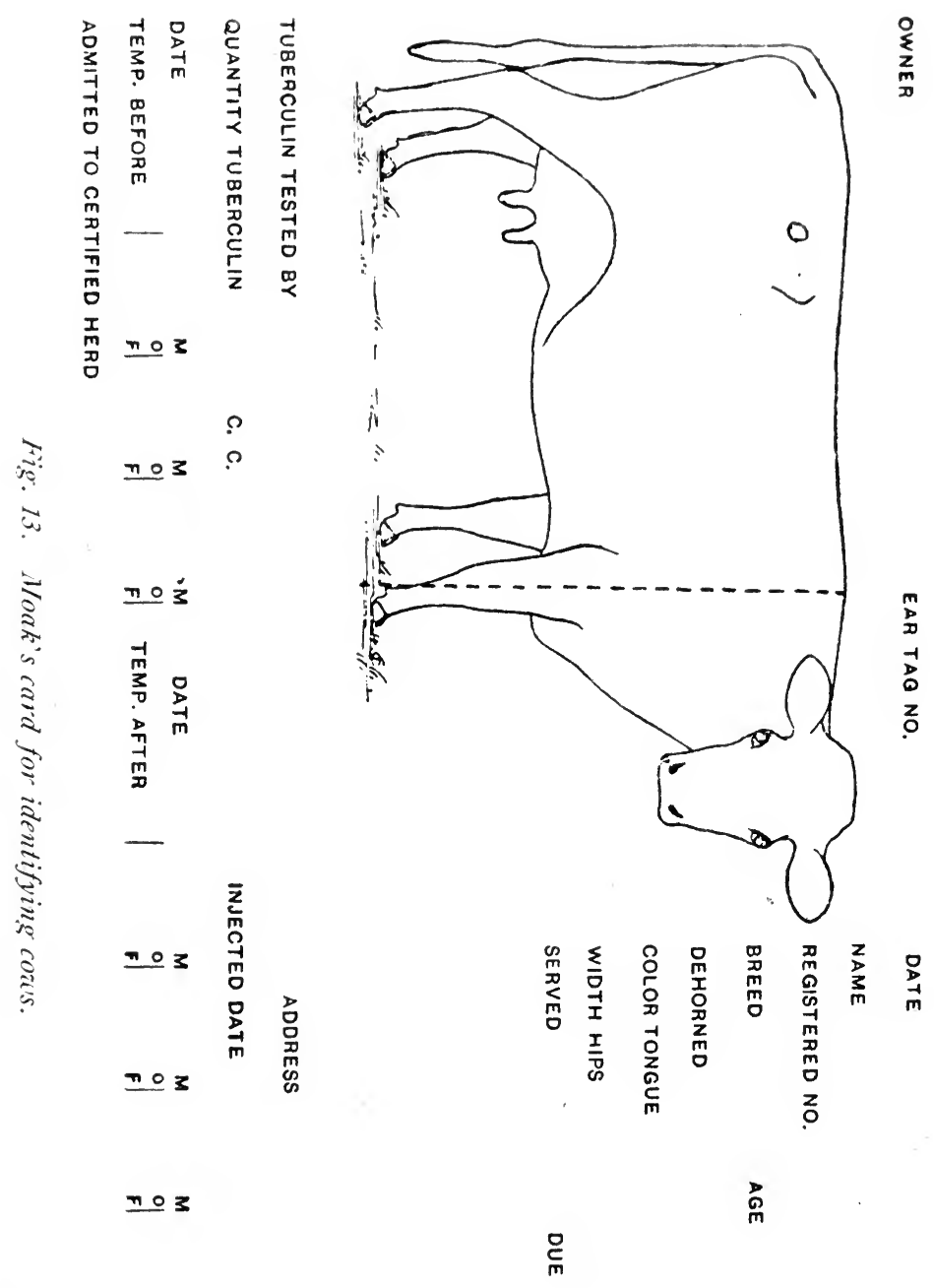

no 3 
It is the purpose here merely to allude to the matter of control of bovine tuberculosis. ' When municipalities interfere with dairymen in the tuberculosis matter, the cry is usually raised that nothing should be done until indemnification is available. Under the conditions ordinarily imposed by a city ordinance, such a claim is absurd.

The slaughter-house always offers an opportunity for the disposal of tubercular animals. The regulations of the Bureau of Animal Industry of the United States Department of Agriculture permit the veterinary inspectors to pass certain slightly diseased carcasses as fit for human food. In most of our abattoirs there is no inspection of meat by Federal or local authorities, consequently we consume regularly the flesh of brokendown tubercular dairy cows. In view of this, the slaughter of slightly diseased cows that have merely reacted to the test, cannot be regarded as especially disgusting. The slaughter of reacting cows does not afford a great loss to the dairyman, for at certain seasons of the year there is not a wide margin of difference between the beef and the dairy value of a scrub cow. It is by no means a simple matter to enforce the clauses of an ordinance requiring that reacting animals be permanently removed from the herd. Unfortunately it is quite necessary to assume that condemned cows may be returned to the herd by stealth. Thorough inspections, with the aid of the identification system, will quite prevent the general practice of such fraud. An instance has come to notice where the owner was so deaf to warning and so blind to the truth regarding the transmissibility of tuberculosis that he kept the reacting cows to suckle dairy calves.

Instances arise in which the dairyman, having dried off a number of reacting cows, keeps them at pasture a year and submits them for a retest later. In general such animals will continue to react from year to year, although some may cease to react because of the ençasulation of the lesions. Such animals unless very closely supervised, are not desirable in a herd free from tuberculosis. There is, furthermore, the great probability that the owner will tamper with the reacting cows by surreptitiously injecting them with tuberculin with the 
purpose of deceiving the veterinarian testing them in good faith. 'The rule, "once condemmed, always condemned," is safest to follow.

Disinfection. The disinfection of a stable after the reacting animals have been removed is a matter that most vitally concerns the dairynan and he might be expected to do this work. In practice, though, it will be found that the dairyman will not do the work thoroughly or may neglect it entirely. It is much better that it be done under the supervision of the veterinarian making the test.

A thorough cleaning of the stable is a prerequisite to the use of the disinfectant and should be carried out with such thoroughness that no manure remains anywhere. Mercuric cliloride is a good disinfectant for use in the stable. It is made up in the proportion of 1 ounce to 8 gallons of water and shonld be mixed in a wooden tub or barrel. The mercuric chloride is best brought into solution in a small quantity of hot water and then diluted with the whole amount of cold water.

On account of the danger of defacing metal work about the mangers by the action of the mercury, it may be well to use some other disinfectant there. A $5 \%$ solution of carbolic acid or of formalin may be used (8).

Education of dairymen concerning bovine tuberculosis. The regulations against bovine tuberculosis in the interest of the public health and without the alternative of pasteurization must eventually result in either driving the dairymen into completely subjugating the disease in their herds, or in the abandonment of the ordinance. Ignorance or skepticism or false economy will induce quite a percentage of dairymen to violate the principles necessary for the control of bovine tuberculosis, in spite of a tuberculin test ordinance. The business can not stand such a drain, and rigid enforcement inevitably results in driving the unfit out of business. The intermittent way in which tuberculin test ordinances have been enforced always lends hope that interference will be but temporary. The ultimate triumph of a tuberculin test ordinance is impossible unless the dairymen are educated and converted on the subject of bovine 
tuberculosis. To this end, the dairymen supplying a city should all be supplied with circulars of information dealing with the problem of the control of bovine tuberculosis. In a large number of states, assistance in preparing such circulars may be had from state veterinary sanitary officials, veterinarians of agricultural experiment stations, and also from the Bureau f Animal Industry at Washington.

Anthrax. This cattle disease is certainly transmissible to nan by inoculation, but the writer has not encountered a report of a case where the infection has been borne by milk.

The disease appears among cattle during warm weather in certain localities. Its onset is so abrupt and death usually occurs with such suddenness that there is little likelihood of a diseased animal's transmitting the disease through the milk. During an outbreak of anthrax it might be enough from the public health standpoint to insist that no cows with a fever be allowed in the dairy. Even such a requirement would ordinarily be superfluous, for a cow with a high fever due to anthrax would not yield milk.

Suppuration. Marked examples of suppuration warrant the temporary rejection of the milk of a cow. Dehorning, or the accidental loss of a horn, is quite apt to lead to infection of the frontal sinuses, and if the discharge is not properly removed it creates a disgusting stench. For this reason dehorning is preferably done when a cow is dry. Open suppurating actinomycotic lesions are objectionable. Small abscesses occur on the backs of cows, due to the presence of larvae, Hypoderma bovis, or H. lineata, popularly called warbles. Trouble is best prevented by squeezing out the larvae when small. Suppuration about the udder is especially objectionable. Mammitis (garget) furnishes good reason for excluding the milk of the cow from sale, even if only one quarter of the udder is involved. Since garget is caused by streptococci, all sorts of streptococcus infections in man have been attributed to the use of milk containing streptococci. Such transmission of infection is possible and probable, but difficult to prove. The subject is further discussed in Chap. VII. 
Cowpox. This eruptive disorder of the skin of the udder is very conmon and terminates in ulcers and frequently in abscesses. At times it would be a very serious matter to demand the rejection of the milk of all cows showing sillall areas of infection. The very common practice of using carbolized vaseline on the lesions practically prevents danger of transmitting infection from these areas when not on the teats. Regulations on the subject might well allow the use of milk when the udder only is involved and under treatment, and exclude cases showing open abscesses or involvement of the teat. The writer is not familiar with reports of cases where the transmission of this disease through the milk has been proven. The fact that vaccination against smallpox is largely practiced has been noted in connection with the subject.

Parturition disturbances. There is a general consensus of opinion that the milk of a cow for about a week after calving (colostrum) has an unusual composition and is unwholesome for human consumption. 'The Federal standard sets this period at ten days, and likewise prohibits the use of milk for fifteen days before calving (Chap. $\mathrm{X}$ ). Besides, during this time the udder is more or less inflamed in consequence of the resumption of function. Cases exhibiting retained placenta, metritis, etc., should not be allowed in the milking herd.

Malta fever. This disease, prevalent on the island of Malta and elsewhere, chiefly in the Mediterranean region, is caused by Micrococcus melitensis. Lately it has been determined by a commission appointed to investigate the disease that it is primarily one of goats and is transmitted through the milk. $M$. melitensis may be found in the milk of apparently healthy goats. The blood serum of such animals givés a positive agglutination reaction with $M$. melitensis, and that of other goats not containing the germs does not. The test has led to the conclusion that $41 \%$ of the goats in Malta are infected. Ten per cent. of them have the germs in the milk. In 1905 a very conclusive demonstration of the relation of goats to the disease was afforded by the shipment of a number of goats from Malta to the United States. The milk was used by the crew of the ship with the result that a number of men contracted Malta fever. The imported animals were slaughtered (2). 
Foot and mouth disease. This highly contagious disease of cattle is transmissible to man through the milk (24). The symptoms in cattle consist of eruption of vesicles in the mouth, around the coronet, between the toes and on the udder, accompanied by a rise of temperature. The mortality is not high, but great losses are incurred by the diminution of the milk flow due to the fever and to the starvation caused by the mouth lesions. Mycotic stomatitis, which occurs occasionally on the Pacific coast and elsewhere, is liable to be confused with foot and mouth disease (18). This last mentioned disease is common in Europe but is not permanently implanted in the United States. It has been introduced several times and successfully eradicated. At the time of writing, the existence of the disease has been discovered in certain areas of Pennsylvania, Michigan and New York.

Milk-sickness. In the early days of the settlement of the central portion of the United States, cases of illness attributed to consuming milk of diseased cattle were not uncommon (16). The symptoms in cattle and in man are quite definite. Fifty years ago the disease had a distinct standing in medicine but of late years it has been all but forgotten, due to its present rarity. Jordan and Harris (11) have recently discovered a focus of infection in the valley of the Pecos River, N. M., which gave them opportunity to study cases in both cattle and man. In man the symptoms, anong others, included vomiting, constipation, and great prostration. They noted the sweetish odor of the breath described in the old literature. Affected cattle in the early stages appeared weak and exhibited a shuffling gait, accelerated breathing, and sometimes trembled and fell. In advanced stages the animal lay with the head to one side as in milk fever, but continued to tremble. Post-mortem examination with bacteriological examination did not result in the identification of any of the well-known cattle diseases. An organism called by them $B$. lactimorbi was regarded as the cause of the disease. 
1. Anderson. The frequency of tubercle bacilli in the market milk of the city of Washington, D. C. Bul. No. 41, Hyg. Lab., L. S. Pub. Health and Mar. Hosp. Serv., Washington, D. C., 1908, p. 163.

2. ANDERSON. The relation of goat's milk to the spread of Malta fever. Bul. No. 41, Hyg. Lab., U. S. Pub. Health and Mar. Hosp. Serv'., Washington, D. C., 1908, p, 195.

3. ARLoIng. Variations of the tubercle bacillus especially from the standpoint of virulence. Trans. Sixth Intern. Cong. on Tuberculosis, Waslington, D. C., 1908.

4. BAKER. Tuberculosis in range cattle in California. Trans. Sixth Intern. Cong. on Tuberculosis, Washington, D. C., 1908.

5. British Royal, Commission on Human and Animai, TubercuLosis. Second interim report. Jour. Comp. Path. and Bact., Vol. XX, 1907, p. 81. (See Ref. 33.)

6. Conference in camera on human and bovine tuberculosis. Jour. Amer. Med. Assoc., Vol. LI, 1908, No. 15, p. 1262.

7. FIBIGER. Investigations into the relations of liuman and bovine tuberculosis and tubercle bacilli. Trans. Sixth Intern. Cong. on Tuberculosis, Washington, D. C., 1908.

8. Haring. The disinfection of stables. Cir. No. 19, Agr. Exp. Sta. Liniv. of Cal., Berkeley, Cal., 1908.

9. Hess. A study of tuberculous contamination of New York City milk. Trans. Sixth Intern. Cong. on Tuberculosis, Washington, D. C., 1908.

10. Holt, Jacobi, Bryant, Prudden and Freeman. Report on the nilk supply of New York City, with recommendations. Arch. Ped., February, 1908.

11. JORDAN and HARRIS. The cause of milksickness or trembles. Jour. Amer. Med. Assoc., Vol. L, 1908, No. 21, p. 1665.

12. Kitasato. The beliavior of native Japanese cattle with regard to tuberculosis. Congress of Arts and Science, Universal Exposition, St. Louis, 1904, Vol. VI, p. 137.

13. KосH. The combating of tuberculosis in the light of the experience that has been gained in the successful combating of other infectious diseases. Jour. Comp. Path. and Ther., Vol. XIV, 1901, p. 203.

14. Косн. The transmissibility of bovine tuberculosis to man. Jour. Comp.Path. and Ther., Vol. XV, 1902, p. 287.

15. КосH. The relation of human and bovine tuberculosis. Trans. Sixth Intern. Cong. on Tuberculosis, Washington, D. C., 1908; Jour. Amer. Med. Assoc., Vol. LI, 1908, No. 15, p. 1256.

16. McCoy. Milk sickness. Bul. No. 41, Hyg. Lab., U. S. Pub. Health and Mar. Hosp. Serv., Washington, D. C., 1908, p. 211. 
17. Mervix. The economic importance of tuberculosis of food-producing animals. Trans. Sirth Intern. Cong. on Tuberculosis, Washington, D. C., 1908.

18. Mohler. Mycotic stomatitis in cattle. Cir. No.51, Bur. Anim. Ind., L. S. Dept. Agr., Washington, D. C., 1904.

19. MoHLER. Infectiveness of milk of cows which have reacted to the tuberculin test. Bul. No.47, Bur. Anim. Ind., I. S. Dept. Agr., Waslington, D. C., 1903.

20. Mohreir and WAshburs. A comparative study of tubercle bacilli from varied sources. Bul. No. 96, Bur. Anim. Ind., l. S. Iept. Agr., Washington, D. C., 1907.

21. Moorf. Bovine tuberculosis. Bul. No. 250), Cornell ('niz'. Agr. Exp. Sta., Ithaca, N. Y., 1908.

22. MoORE. The dissemination and control of tuberculosis as illustrated in the bovine species. Iroceedings of the Serenth Annual Conference of Sanitary Officers, New York State Department of Health, 1907.

23. MoorE. Can tuberculosis be eliminated from cattle? N. I. State Jour. of Med., Vol. VIII, May, 1908, No. 5, p. 249.

24. MOORE. The pathology of infectious diseases of animals. Ithaca, N. Y.: Taylor \& Carpenter, 1908.

25. Moore. Tuberculin and its use in the control of bovine tuberculosis. Cir. No. 1, N. I. State Vet. Col., Ithaca, N. Y., 1908.

26. Moussu. The intradermo-reaction to tuberculin in animals. Trans. Sixth Intern. Cong. on Tuberculosis, Washington, D. C., 1908.

27. MïLLER. Milk and dairy products as sources of infection in tuberculosis. Jour. Com. Path. and Ther., Vol. XIX, 1906, p. 19.

28. OSTERTAG. Untersuchung über den Tuberkelbazillengelialt der Milch von Kühen, welche lediglich auf Tuberkulin reagiert haben, klinische Ersheinungen der Tuberkulose aber nicht zeigen. Zeitschr. Fleisch. u. Milchhyg., Bd. IX, No. 1L, S. 221.

29. RABINowitsch und KEMPNER. Beitrag zur Frage der Infectiosität der Milch tuberculöser Kühe, sowie über den Nutzen der Tuberculinimpfung. Zeitschr.Hyg.u. Infectionskrank., Bd. XXXI, 1899, S. 137.

30. RAVENEL. The passage of tubercle bacilli through the normal 111testinal wall. Jour. Med. Research, N. S., Vol. V, 1903-4, p. 460.

31. Report of Committee on Resolutions. Jour. Amer. Med. Assoc., Vol. LI. 1908, No. 15, p. 1260.

32. REYNOLDS and BEEBE. Dissemination of tuberculosis by the manure of infected cattle. Bul. No. 103, Uniz' of Minn. Agr. Exp. Sta., St. Anthony Park, Minn., 1907.

33. Royai, Comnission, appointed to inquire into the relations of human and aninal tuberculosis. Second interin report. Part I, Re- 
port; Part II, Appendix. Vol. I, The pathogenic effects of bovine viruses, by Dr. A. Stanley Griffith. Vol. II, pp. 1-616, Vol. II, pp. 6171217, The pathogenic effects of human viruses, by Dr. L. Cobbett. Vol. III, Additional investigations of bovine and luman viruses, by Dr. I . Cobbett, Dr. A. Stanley Griffitl and Dr. F. Griffith. Vol. IV, Comparative histological and bacteriological investigations, by Arthur Fastwood, M. I).

34. Russfin. The history of a tuberculous lerd of cows. Bul. No. 78, I'niz' of W'is. Agr. Exp. Sta., Madison, Wis., 1899.

35. Russiri. A lesson in bovine tuberculosis. Bul. No. 11t, L'niz. of Wis. Agr. Exp. Sta., Marlison, Wis., 1904.

36. Russer.r. Two ways of treating tuberculosis in lerds. Bul. No. 126, L'niz' of Wis. Agr. E.rp. Sta., Madison, Wis., 1905.

37. Russer.,. The sprearl of tuberculosis through factory skin $111 \mathrm{ilk}$, with suggestions as to its control. Bul. No. 173, Lniz' of His. Agr. Exp. Sta., Madison, Wis., 1907.

38. SAImon. The tuberculin test for tuberculosis. Cir. No.79, Bur. Anim. Ind., L. S. Dept. Agr., Washington, D. C., 1905.

39. SAmMON and SMITH. Tuberculosis of cattle. Cir. No. 70, Bur. Anim. Ind., L. S. Dept. Agr., Washington, D. C., 1904.

40. Sanitary milk production. Cir. No. 11., Bur. Anim. Ind., U. S. Dept. Agr., Waslington, D. C., 1907.

41. SchrofDER. The occurrence and significance of tubercle bacilli in the feces of cattle. Trans. Sixth Intern. Cong. on Tuberculosis, Waslington, D. C., 1908.

42. Schrofider. The unsuspected but dangerously tuberculous cow. Cir. No. 118, Bur. Anim. Ind., L. S. Dept. Agr., Waslington, D. C., 1907.

43. Schroeder. Tuberculous infection through milk. Pediatrics, Vol. XX, No. 7, p. 422.

44. SCHROEDER and CotTon, Experiments with milk artificially infected with tubercle bacilli. Bul. No. 86, Bur. Anim. Ind., L. S. Dept. Agr., Washington, D. C., 1906.

45. Schroeder and CotTton. 'Tubercle bacilli in butter. Cir. No. 127, Bur. Anim. Ind., U. S. Dept. Agr.. Washington, D. C., 1908.

46. Schrofiner and MoHi,ER. The tuberculin test of hogs and some methods of their infection with tuberculosis. Bul. No. 88, Bur. Anim. Ind., L. S. Dept. Agr., Washington, D. C., 1906.

- 47. Surth. A comparative study of bovine tubercle bacilli and of human bacilli from sputum. Jour. Exper. Med., Vol. III, 1898, Nos. 4 and 5 .

48. Smith. Studies in mammalian tubercle bacilli (III). Jour. Med. Research, N. S., Vol. VIII, 1905, p. 253. 
49. SMiтh. The channels of infection in tuberculosis, together with some remarks on the outlook for a specific therapy. Trans. Mass. Med. Soc. for 1907.

50. Smith. The bovine and the human type. Jour. Amer. Med. Assoc., Vol. LI, 1908, No. 15, p. 1258. (A journal abstract.)

51. Solis-Cohfis. Bacteriological examination of the feces as a means of early diagnosis in tuberculosis. "Transactions Third Annual Meeting of the National Association for the Study and Prevention of Tuberculosis, p. 228.

52. Von BEHRING. The suppression of tuberculosis, etc. New York: J. Wiley \& Sons.

53. WARD. The identification of cows. The Cornell Conntryman, Vol. III, 1906, No. 5, p. 110.

54. Ward and Haring. Bovine tuberculosis. Bul. No. 199, Lniz'. of Cal. Agr. Exp. Sta., Berkeley, Cal., 1908.

55. WARD and HARING. The prevalence of tuberculosis among dairy cattle in the vicinity of San Francisco, California. Trans. Sixth Intern. Cong. on Tuberculosis, Washington, D. C., 1908.

56. White and McCAMPBEI. The ophthalmo-tuberculin test in cattle. Trans. Sixth Intern. Cong. on Tuberculosis, Washington, 1908. 
CHAP'TER V.

\section{MUNICIPAL SANITARY CONTROL OF MILK.}

Control of milk supply. The dairy business is generally regulated by a licensing system. Municipal ordinances define the qualities required in the milk sold, and specify certain methods that shall or shall not be practiced in its production. The isstuing of a license to sell the milk may be made conditional upon the compliance with certain demands. The desired standard may be maintained by a system of frequent renewal of license, by provisions for the revocation of license, or by the exaction of other penalties through the courts.

Inspection. Knowledge of the requirements of municipal milk inspection and of methods of accomplishing desired results has been increasing very rapidly of late. A particularly careful and exhaustive study of present conditions and remedial measures has recently been made in Washington by a Conference appointed by the Commissioners of the District of Columbia (3). The report of that conference with accompanying papers is a valuable guide for shaping new legislation on milk sanitation. The organization, administrative methods and legal features of municipal milk inspection in Washington have been described by Woodward (18).

The inspection of equipment of the establishments and the methods of handling milk constitutes an important part of any municipal milk inspection service. In actual practice, the inspector will fall far short of accomplishing the best results unless he becomes an instructor in dairy practice, as well as an agent to detect violations of law. He must point out on the spot defects and ways of improvement, which, if not carried out, may be made occasion for prosecution. He must also furnish a comprehensive report to his superior officer in regard to existing conditions. 
The dairy score card. The dairy score card has been found a most useful means for simplifying the work of dairy inspection. The system is adapted from a method used to score the conformation of cows, etc. All of the essential facts of importance regarding equipnent and methods are tabulated in an orderly manner, and numerical weight is assigned to each point in proportion to its importance. The inspector takes up each point in detail and enters on the score card a number expressing his opinion of the relation that the condition in question bears to the standard of perfection. The total score represents his very carefully analyzed opinion of the condition of the dairy as compared with the standard of perfection followed.

The score card has many advantages. The tendency to neglect details in the inspection is checked, for the inspector has before him comprehensive suggestions. If he is inexperienced, any tendency to overestimate or underestimate the importance of various details is obviated. In making recommendations regarding certain details his advice is made more weighty by the score card, to which he may refer the dairyman. A copy of the score, left with the dairyman, is a permanent record of the criticisms, as is likewise the copy kept by the inspector. By comparison of the scores made at different times the progress of improvement may be measured.

Inspection with scoring can most readily bring about the proper equipment of dairies in the matter of buildings and equipment, such as cooling and scalding apparatus, etc. These features are necessary and desirable, but beyond them is the problem of ensuring the practice of a uniformly thorough aseptic technic. During the visits of the inspector some idea of the technic may be obtained by observation. The necessity for haste to accomplish results in some cases prevents the inspector from personally observing the practice of all the details of milk handling. Experience in observation, supplemented by cross-questioning, enables him to draw out information on matters that he may not have time to wait to see. In any event, there are long periods between visits when the methods are not under control. The magnitude of dairy inspection makes it difficult to have these visits frequent enough. New 
York City has 30 inspectors to look after thirty or forty thousand dairies and follow the product to the consumer. Only 15 of these men work outside of the city (4). Washington is more fortunate with 960 dairies for 6 inspectors (18). These men visit on an average 2.8 dairies per day.

The situation in these cities suggests a doubt as to whether inspection work of our larger cities can be expanded sufficiently to bring about a reform in the methods of farm laborers ignorant of aseptic technic.

The following score card is one adopted by the Official Dairy Instructors' Association, at the meeting in July, 1908. This latest modification represents the consensus of opinion of the body of men most competent to judge. such matters, including in its membership those who have been most active in the introduction of the score card and most experienced in its use.

UNITED STATES INPAR'TMENT OF AGRICLLTURE, BUREAU OF ANIMAL, INDUSTRY,

DAIRY DIVISION,

SANITARY INSIECCTION OF DAIRIES.

DAIRY SCORE: CARD.

Adopted by the Official Dairy Instructors' Association. (subject to revision at future meetings.)

Owner or lessee of farm

P. O. Address

State

Total number of cows.

Number milking.

Gallons of milk produced daily

Product is retailed by producer in

Sold at wholesale to

For milk supply of..

Permit No.

Date of inspection 190

REMARKS 


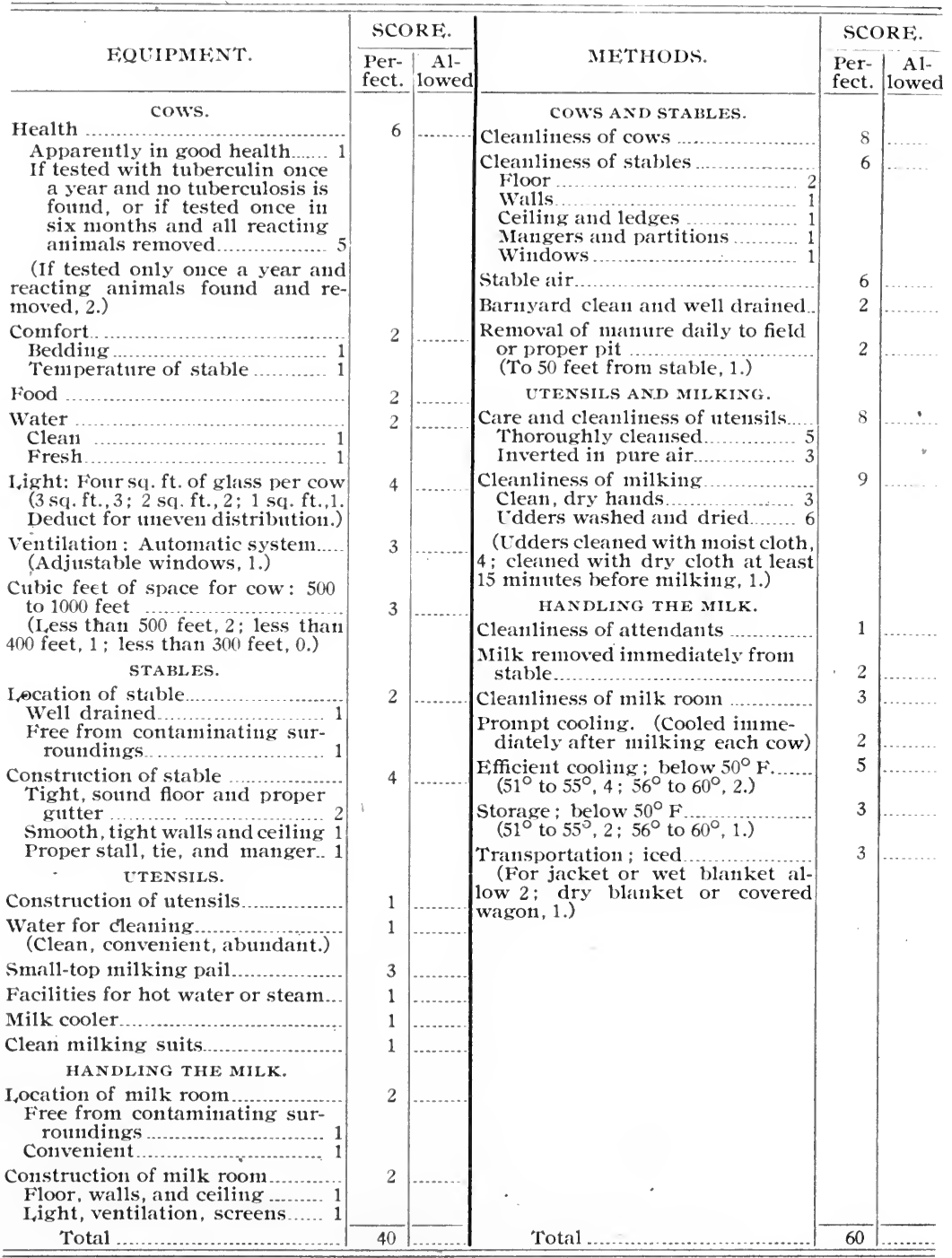

Score for equipment + Score for methods Final Score.

NOTE 1.-If any filthy condition is found, particularly dirty utensils, the total score shall be limited to 49 .

Note 2.-If the water is exposed to dangerous contamination or there is evidence of the presence of a dangerous disease in animals or attendants, the score shall be 0 . 
The score card eliminates the wide variations of individual judgment in criticising dairy conditions. There still renains room for variations between the work of different inspectors. It would hardly be fair to compare a group of dairies on the basis of the work of several inspectors. Professor R. A. Pearson has introduced a scheme to eliminate the effect of variations in individual judgment. The inspectors are furnished a list of questions, the answers to which will bring out the actual condition of the dairy. The answers made by the inspector are placed in the hands of an expert who, in his office, compiles the facts in the form of a score. Thus the work of a number of inspectors may be unified by one mind and the quality of uniformity imparted to the work of all. The system is being used with satisfaction by the Boards of Health of Ithaca, N. Y., Geneva, N. Y., and elsewhere. The blanks used are reproduced below. The description of what constitutes perfection under each heading is a commendable feature.

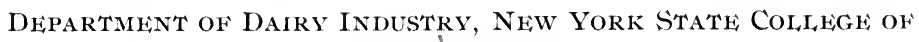
AGRICUI,TURE.

MILK INSPEC'TION.

Dairyman Date.

P. O. . Location.

No. Cows 111ilking....... In herd. Qts. Milk Cans or Bottles. Milk sold to I icense No.

Report by At 111ilking tine?

Hour M.

I. Health of the herd and its protection.

Do all cows appear liealtly?

Are udders sound and free from signs of disease?

Are cows tuberculin tested?

Date of last test

By whom.

Is the stable well built to protect from the weather?

Are cows brought in during bad storms?

How many hours are the cows out daily?

Width of stall Length. 
Is the stall comfortable? How are the cows tied?

Kind and quality of bedding.

Where are cows kept when sick and at calving time?

Is the stable well located?

Number and size of windows

Size of the stable, length. wịdtlı. leight

How ventilated?

Kinds of feeds used

Are they of good quality and proportions?

Source of water for cows.

Method of watering

II. Cleanliness of the coa's and their surroundings.

Are the cows clean? How are they cleaned?

Is the hair clipped about the urder?

Is the udder cleaned before milking? How?

When?

Is the stable free from accumulation of cobwebs, dirt and dust?...

Is the stable white-washed?

Kinds and number of other animals, if any, in same roon with cows

Samie, adjacent rooms.

What openings between?

Is the stable protected from such sources of contanination as privy, etc. ?

How often is the manure removed from the stable?

Is the barnyard free from manure pile? And mud holes?

Is the pasture clean and free from injurious plants? And mud holes?

Is the stable provided with dust-tight ceiling? And partitions?

Is feeding done before or after milking?

Is the floor swept or dampened before milking?

Is the air free from dust and odors?

III. Construction and care of the utensils.

Are all utensils such that they can be thoroughly cleaned?

Method of washing utensils?

How are the utensils sterilized? 
Is the water used for washing utensils pure?

How do you know?

What is its source?

Is the source protected against contamination?

How are utensils cared for after cleaning?

Is a small-top pail used for milking? If so, what style and size of opening?

IV. Health of employees and manner of milking.

What evidence is there of absence of contagious disease and of exposure of fanily and employees to disease?

Are the milkers clean personally?

Do the milkers wear clean over-all suits?

How often are the over-alls washed?

Do the milkers wash their hands just before milking?

where?

Do milkers have wet hands when milking?

Are milkers careful not to dislodge liair and dirt from the cow while milking?

Is the foremilk discarded?

V. Handling the milk.

How is the milk cooled?

How soon after milking is the milk cooled?

To what temperature?

Is the milk hanclled in a room detached from the stable?

What kind of floor?.

Is the milk room used exclusively for milk, and is it free from dirt and odors?

At what temperature is the milk kept after cooling?

How is $111 \mathrm{k}$ k cared for during transportation to market? 


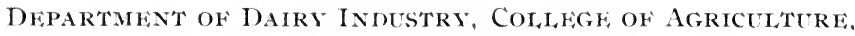
CORNEI, UNIVERSITS.

Score Card for Production of Sanitary . Wilk.

Date

Dairy of

P. O.

\begin{tabular}{|c|c|c|c|c|}
\hline \multirow[t]{2}{*}{$\begin{array}{l}\quad \text { I. } \\
\text { Health of the } \\
\text { lierd and } \\
\text { its protec- } \\
\text { tion. }\end{array}$} & $\begin{array}{l}\text { Health and comfort of the cows and } \\
\text { their isolation when sick or at } \\
\text { calving time................... } \\
\text { Location, lighting and ventilation of } \\
\text { the stable.... } \\
\text { Food and water. }\end{array}$ & $\begin{array}{l}45 \\
35 \\
20\end{array}$ & SCORE. & \multirow[t]{2}{*}{$\begin{array}{c}\text { Remarks } \\
\text {. }\end{array}$} \\
\hline & Total ............... & 100 & & \\
\hline \multirow{2}{*}{$\begin{array}{l}\quad \text { II. } \\
\text { Cleanliness } \\
\text { of the cows } \\
\text { and their } \\
\text { surround- } \\
\text { ings. } \\
\end{array}$} & 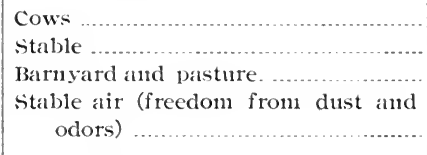 & $\begin{array}{l}30 \\
20 \\
20 \\
30 \\
\end{array}$ & & \\
\hline & Total …................. & 100 & & \\
\hline \multirow[t]{2}{*}{$\begin{array}{l}\text { III. } \\
\text { Construction } \\
\text { and care of } \\
\text { the uten- } \\
\text { sils. }\end{array}$} & $\begin{array}{l}\text { Constrnction of ntensils and their } \\
\text { cleaning and sterilizing } \\
\text { Water supply for cleaning and loca- } \\
\text { tion and protection of its sonrce... } \\
\text { Care of ntensils after cleaning } \\
\text { Ese of small-top milking pail }\end{array}$ & $\begin{array}{l}25 \\
20 \\
15\end{array}$ & & \\
\hline & 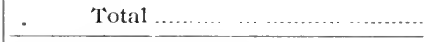 & 100 & & \\
\hline \multirow[t]{2}{*}{$\begin{array}{l}\text { IV. } \\
\text { Healtil of em- } \\
\text { ployees and } \\
\text { manner of } \\
\text { milking. }\end{array}$} & $\begin{array}{l}\text { Health of employees } \\
\text { Clcan over-all milking suits and milk- } \\
\text { ing with clean, dry hands.......... } \\
\text { Qniet milking, attention to cleanli- } \\
\text { ness of the ndder and discarding } \\
\text { forenilk. }\end{array}$ & 30 & & \\
\hline & Total & 100 & & \\
\hline \multirow[t]{3}{*}{$\begin{array}{c}\text { V. } \\
\text { Handling } \\
\text { the milk. }\end{array}$} & $\begin{array}{l}\text { Prompt and efficient cooling } \\
\text { Handling milk in a sanitary room } \\
\text { and holding it at a low tempera- } \\
\text { ture......................................... } \\
\text { Protection during transportation to } \\
\text { market }\end{array}$ & 35 & & \\
\hline & Tota1 & 100 & & \\
\hline & TOTAI, OF AI, I, SCORES .... & 500 & & \\
\hline $\begin{array}{l}\text { If the total of al } \\
480 \text { or abo } \\
450 \text { or abo } \\
400 \text { or abo } \\
\text { Below } 400\end{array}$ & $\begin{array}{l}\text { And scores is } \\
50 \text { or above....... } \\
\text { ve. } \\
\text { ve. }\end{array}$ & & The sani & $\begin{array}{l}\text { ary conditions are } \\
\text { XCEI,LENT } \\
\text { OOD } \\
\text { IEDIUM } \\
\text { OOR }\end{array}$ \\
\hline
\end{tabular}

The sanitary conditions are

scored by 
[Rezerse.]

A BRIFF DFSCRIPTION OF WHAT CONSTITUTES PERFFC'T UNDER FACH HEADING.

I. Health. No evidence of chronic or infectious disease or of acute disease in any member of the herd on the dairy premises. Freedom from tuberculosis proven by the tuberculin test marle within one year.

Comfort. Protection from weather extremes. Stall comfortable, at least 3 feet wide for a sinall cow, or $3 \frac{1}{2}$ feet for a large cow ; length of stall sufficient for cow to rest easily. Sufficient bedding. Frequent out-door exercise.

Isolation. Removal of cows to comfortable quarters outside of the dairy stable, when sick or at calving time.

Location of Stable. Flevated, with healthful surroundings.

Lighting. As light as a well lighted living room, and with not less than four square feet for light from the east, south or west, for each cow.

l'entilation. An adequate ventilating system of the King or other approved pattern, and, except wlien the stable is being cleaned, no marked stable odor.

Food. Clean, wholesone feeding stuffs, fed in proper quantities.

Water. Clean, freslı water, free from possibility of contanination by disease germs.

II. Cozs. Cleaned by thorough brushing, and where necessary by washing; 110 dust nor dirt on the hair (stains not considered). The udler thoroughly cleaned by brushing at least thirty minutes before milking, and by washing just before milking, leaving the udiler damp to cause dust to adhere.

Stable. Free from accumulation of dust and dirt except fresh manure in the gutter. Apart from horses, pigs, privy, poultryhouse, etc.

Barnyard and Pasture. No injurious plants, no mudhole nor pile of manure or any decaying substance where cows have access.

Stable Air. Free from floating dust and odors. Tight partition or floor between the space occupied by cows and that used for storage of feed or other purpose.

III. Construction of Ltensils. Non-absorbent material and every part accessible to the brusli, and, except inside of tubes, visible when being cleaned. 
Cleaning. Thorough cleaning with brush and hot water, and rinsing. No laundry soap. Thorough sterilization.

W'ater, from a source known to be pure; protected from contamination from seepage, or surface drainage.

Care of I'tensils. Such as to avoid contamination by dust as well as coarser clirt.

Small-top Pail,--with opening not over seven inches in diameter, and at least one-third of this opening protected by hood.

IV. Employees,-free from contagious disease and not dwelling in or frequenting any place where contagious disease exists.

Milking Suits,-freshly laundered and clean; ample to protect from dust and dirt from the milker's person or clothing.

Milker's Hands. Hands and teats dry when nilking. Hands thoroughly cleaned before milking each cow.

Milking Quietly,--so as to avoid dislorlging dirt from cow's hair. At least four streams of foremilk from each teat to be discarded into a separate vessel.

V. Cooling. Cooled within fifteen minutes of milking, to temperature below 45 degrees $\mathrm{I}$.

Handling, -in a room used exclusively for handling milk, and free from dust, lirt and orlors ; and the milk after being cooled, always at a temperature below 45 regrees.

Protection during transportation. Protected from dirt by tightly - closed receptacles, temperature always below 45 degrees F.; not delayed in transit, reaching market within twenty-six lours after milking.

Through the efforts of the Dairy Division, Bureau of Animal Industry, U.S. Department of Agriculture, the score card is being widely used by municipalities. On June 30th, 1908, the score-card system of inspection had been adopted in 60 cities of the United States, located in 25 states, and in one Canadian city. A score card for use in California should be slightly modified to meet local conditions. On account of the milder climate, cows are not confined in the stable so long and ventilating systems, etc., are of less importance. The score card need not necessarily be recognized in legislation, for the publication by the board of health of the scores of the dairies 
furnishes an incentive for improvement. An example of legal recognition of the score card is as follows:

"STANDARI Baskin on Score Carn. No milk shall hereafter be sold or offered for sale or exchange in the city of New Brunswick which shall be produced in dairies having a rating below 60 per cent. as based on the score card adopted by the Board of Health, City of New Brunswick, State of New Jersey."

Improvement in Richmond, l'a. The score card has been found a useful means for recording the improvements in the equipment and methods of milk production. The results obtained by Lery (12) in Richmond, Virginia, are most striking. The inanguration of a system of dairy inspection in which the score card was used gave opportunity for recording the change in dairy conditions from month to month. The results are given in tabular form below.

TABIE IV.

THF, PERCENTAGE OF DAIRY FARMS IN VARIOUS CLASSFS DURING THE FIRST TWELVE MONTHS OF DAIRY

INSPECTION IN RICHMOND, VA.

May 1, 1907, to May 1, 1908.

\begin{tabular}{|c|c|c|c|c|c|c|c|c|c|c|c|c|}
\hline \multirow{3}{*}{ CIASS. } & \multicolumn{12}{|c|}{$\begin{array}{l}\text { PERCENTAgE OF ALI DAIRIES INSPECTED Fok } \\
\text { THE MONTH WHICH FELL IN FaCh Class. }\end{array}$} \\
\hline & \multicolumn{8}{|c|}{1907} & \multicolumn{4}{|c|}{1908} \\
\hline & 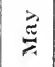 & $\stackrel{\Xi}{\Xi}$ & 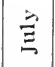 & $\stackrel{\dot{b i}}{\Xi}$ & $\stackrel{\ddot{U}}{\ddot{U}}$ & $\stackrel{\text { ப் }}{0}$ & हैं & $\stackrel{\ddot{U}}{\varrho}$ & $\stackrel{\dot{\Xi}}{\Xi}$ & $\frac{\hat{U}}{1}$ & 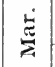 & $\frac{\bar{E}}{\frac{2}{4}}$ \\
\hline Scoring below $30 \ldots \ldots \ldots \ldots$ & 13.8 & 26.5 & 3.9 & 4.0 & & & & & & & & \\
\hline Scoring between 30 and $40 \ldots \ldots . .$. & 30.8 & 42.9 & 21.0 & 10.7 & & & & & & & & \\
\hline Scoring between 40 and $50 \ldots \ldots \ldots$ & 26.2 & 22.4 & 38.2 & 29.4 & 40.0 & 23.7 & 14.8 & 15.8 & 2.8 & & & \\
\hline Scoring between 50 and 60 . & 13.8 & 8.2 & 22.4 & 33.3 & 45.0 & 35.6 & 45.9 & 36.8 & 11.3 & 13.6 & 6.8 & 5.7 \\
\hline Scoring between 60 and $70 \ldots$ & 10.8 & & 13.2 & 22.6 & 12.5 & 33.9 & 29.5 & 23.6 & 35.2 & 44.1 & 39.8 & 34.3 \\
\hline Scoring between 70 and $80 \ldots$ & 4.6 & & 1.3 & $\ldots$ & 3.5 & 6.8 & 8.2 & 18.4 & 31.0 & 25.4 & 34.2 & 42.9 \\
\hline Scoring between 80 and 90 . & & & & & & & 1.6 & 5.4 & 19.7 & 16.9 & 19.2 & 17.1 \\
\hline A verage of all scores for month. & 41.5 & $\mid \overline{36.4}$ & 47.5 & 50.5 & 51.4 & 57.0 & 58.4 & 60.5 & $\mid 70.4$ & 69.6 & 71.5 & 72.0 \\
\hline
\end{tabular}

The results are shown in graphic form in Fig. 14. 

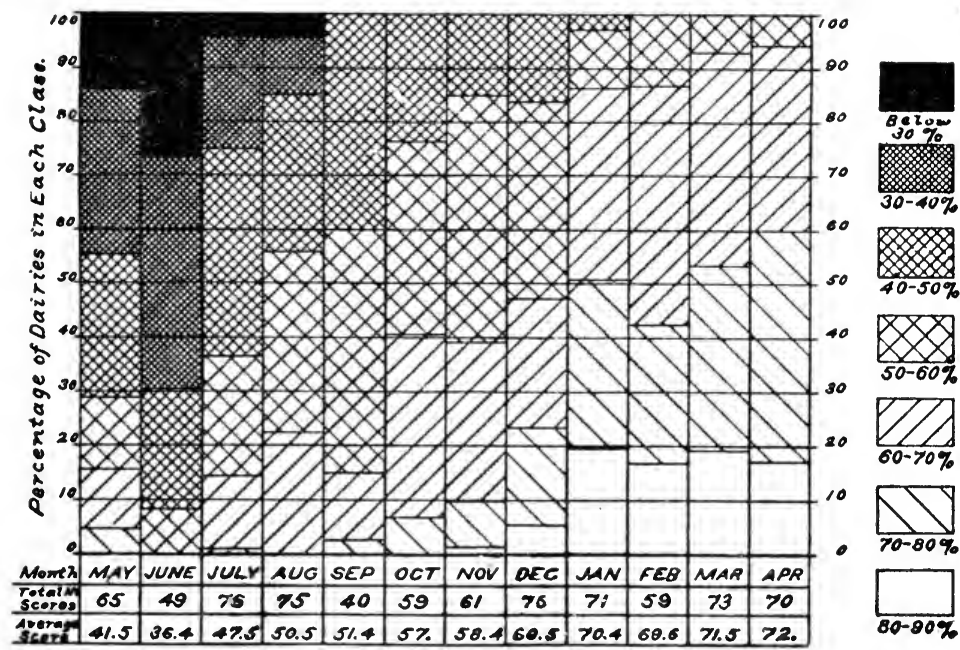

Fig. 17. Diagram showing improzement in dairy scores in Richmond, l'a. (12).

Washington milk supply. Webster (17) has reported the scores of the dairies supplying Washington as shown in the following table:

TABLE Y.

SCORES OF IAIRIES SUPPLYING WASHINGTON.

\begin{tabular}{|c|c|c|c|c|c|c|}
\hline \multirow{2}{*}{ Scoring from } & \multicolumn{2}{|c|}{ Virginia. } & \multicolumn{2}{|c|}{ Maryland. } & \multicolumn{2}{|c|}{ District of Columbia. } \\
\hline & Number. & $\%$ of all. & Number. & $\%$ of all. & Number. & $\%$ of all. \\
\hline 0 to 10 & & $\therefore \ldots \ldots$ & & . & 48 & \\
\hline 10 to 20 & & & 4 & .76 & & \\
\hline 20 to 30 & 7 & 2.18 & 76 & 14.44 & 2 & 3.02 \\
\hline 30 to 40 & 44 & 14.96 & 173 & 32.85 & 7 & 10.60 \\
\hline 40 to 50 & 83 & 28.23 & 164 & 31.18 & 13 & 19.69 \\
\hline 50 to 60 & 89 & 30.20 & 74 & 14.01 & 21 & 31.81 \\
\hline 60 to 70 & 53 & 18.02 & 22 & 4.18 & 13 & 19.69 \\
\hline 70 to 80 & 14 & 4.42 & 10 & 1.90 & 9 & 13.63 \\
\hline 80 to $90 \ldots$. & 3 & 1.02 & 3 & .55 & 1 & 1.51 \\
\hline 90 to $100 \ldots$ & 1 & .34 & & & & \\
\hline
\end{tabular}

Educational activities. The Dairy Division of the Bureau of Animal Industry has further encouraged education as a factor 
in the improvement of the milk supply. In co-operation with the Cleveland (Ohio) Chamber of Commerce, a city milk and cream contest was held (11). The entries in all classes were judged with the assistance of score cards, A satisfactory number of entries was made, and the interest in results constituted a potent educational factor.

Important features in dairy practice may be emphasized by the use of posters printed on muslin, like that in Appendix E.

Inspection of cows. The examination of the cows should inclucle a manipulation of the udder in each case, for by this means only can udder disease be detected. In suspicious cases, a little milk should be drawn from each teat. Among the conditions revealed may be acute mammitis, various skin eruptions, external abscesses of the udder or teats, etc. Varying degrees of induration due to mammitis are not uncommon. A very marked hardening of one or more quarters may be due to tuberculosis, but the correctness of the suspicion is best verified by a bacteriological examination of the discharge, if any is obtainable. Other objectionable conditions are more easily recognized, such as the various inflammatory conditions which, when neglected, give rise to offensive odors. It is the general practice to keep such minor cases in the regular milking herd, and to neglect rather than treat the conditions. A much more satisfactory arrangement would be afforded by arranging a hospital, where all cows with disgusting affections could be milked and treated.

Inspection of dairy apparatus. Excellence of technic is of fundamental importance in milk production, and the condition of utensils, is an excellent index of the standard prevailing in the dairy. The sources of contamination, with reference to utensils and methods of avoiding them are discussed in Chapters I and IX. There are certain pieces of dairy apparatus that invite neglect in cleaning and merit particular attention. Milk pumps, milking machines, bottling machines, rubber pipe, faucets, metal pipes with elbows, rusty pails, strainers (both metal and cloth) all are danger points with reference to the contamination of milk.

In the care of milk utensils is to be found the one great uni- 
versal fault of ordinary dairymen; namely, that the heating of utensils after washing is not thoroughly done.

Inspection of water supply. The source of the water supply with reference to possible contamination by the germs of typhoid fever is of great importance. There are many ways in which contaminated water may become a source of clanger to milk. Deliberate watering of milk, accidental watering through leaks in apparatus, or rinsing apparatus in cold water, are some of the more common channels of contamination.

If the supply is from a shallow dug well, its relation to the privy or area where chamber slops are thrown out deserves careful attention. The possibility of contamination by underground drainage depends upon the character of the soil, the slope of the land and the distance. It certainly is not asking too much that the privy be at least 100 feet from the well under any condition. The protection of the well from surface drainage is important. Chickens will visit the privy vault if they have opportunity, and then may go to the puddle of water around the well for a drink.

Driven wells offer similar dangers of contamination from holes in casings, but in general furnish a more reliable source of water. Springs and streams offer obvious possibilities for contamination. Bolton $(1,2)$ has very thoroughly discussed the subject of water supply for dairies and the bacteriological examination of the same.

Scope of inspection. Every stage in the progress of milk from the dairy to the consumer offers conditions necessitating sanitary supervision. Attention should be paid to milk at the farm, during transportation to shipping point, at shipping point, during railroad transportation, at the railroad station, at the city dairy depot, on city wagons and in the retail store. It is well to go even farther and instruct the consumer about the care of milk. Methods of transportation attract particular attention in relation to speed and means employed for refrigeration. The distributing milk depot offers opportunity for re-infection from utensils or attendants.

The score card for city milk plants. The inspection of city milk plants is likewise facilitated by the use of the score card. 
U. S. DFPARTMFNT OF AGRICIITURE, BUREAT OF ANIMAI, INDUSTRY, DAIRY DIVISION.

SANITARY INSPECTION OI' CITY MIIK PIAANTS.

Uwner or Manager

Trade name

City.

Street and No.

State

Nimber of wagons

Gallons sold daily $\left\{\begin{array}{l}\text { Milk... } \\ \text { Crean1 }\end{array}\right.$

Permit or license No.

Date of inspection

MII,K ROON.

Location

Construction-

Floor

IValls and ceiling.

Irainage

Cleanliness

Light and ventilation

Fquipnent-

Arrangement

Construction-

Sanitary

Durability

Condition

Cleanliness

SCORE.

Perfect. Allowed.

REMARKS.

MII, K.

Handling

Storage

SAI,ES ROOM.

Location

Construction

Equipment

Cleanliness

WAGONS.

General appearance ......2

Irotection of product.

Cleanliness

Total

$53\}$

10

$\left.\begin{array}{l}\ldots \\ 3 \\ 3 \\ 4\end{array}\right\}$

10

10

15

10

$\left.\begin{array}{r}3 \\ 2 \\ 2 \\ 3 \\ 5\end{array}\right\}$

5

15

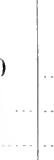

…

- in

$\mid$

Sanitary conditions are . . E Excellent

Good

Fair ........ Poor

Suggestions by inspector.

Signed.

Inspector. 


\section{[Reverse.]}

\section{Sanitary Inspection of City Mil,k Piants.}

\section{DIRECTIONS FOR SCORING.}

MIII, ROON.

Location.-If not connected by door with any other building, and surroundings are good, 10; when connected with other roons, such as kitchens, stables, etc., make deductions according to conditions.

Construction.-If good cement floor, and tight, smooth walls and ceilings, and good drainage, allow 10; deduct for cracked or decayerl floors, imperfect wall and ceiling, etc.

Cleanliness.-If perfectly clean throughout, allow 15; derluct for barl odors, anclean floor and walls, cobwebs, unnecessary articles stored in room, etc.

Light and ventilation.-If window space is equivalent to $15 \%$ or more of the floor space, allow 5; deduct 1 point for every $3 \%$ less than the above amount.

\section{Equipment:}

Arrangement.-Allow 3 points for good arrangement; if some of the equipment is out of doors or so placed that it can not be readily cleaned, make deductions according to circumstances.

Condition.-If in good repair, allow 4 points; make deductions for rusty, wor11-out, or damaged apparatus.

\section{Construction.-}

Sanitary: If seams are smooth, and all parts can be readily cleaned, allow 2. Deduct for poor construction, from sanitary standpoint. Durability: If made strong and of good material, allow 2. Deduct for light construction and poor material.

Cleanliness.-If perfectly clean, allow 8 points; make deductions according to amount of apparatus improperly cleaned.

MIILK.

Handling. - If milk is properly cooled to $50^{\circ} \mathrm{F}$. or lower, allow 12 points; or if pasteurized at a temperature of $149^{\circ} \mathrm{F}$. or above and promptly cooled to $50^{\circ}$ or lower, allow 12 points. Deduct 1 point for every $2^{\circ}$ above $50^{\circ}$. If milk is pasteurized imperfectly, deduct 6 points. If milk is inproperly bottled or otherwise poorly handled, make derluctions accordingly.

Storage.-If stored at a temperature of $45^{\circ} \mathrm{F}$. or below, allow 8 points; deduct 1 point for every $2^{\circ}$ above $45^{\circ}$.

\section{SAIES ROOM.}

Location.-If exterior surroundings are good and building is not connected witl any other under undesirable conditions, allow 2; for fair conditions, allow 1; poor conditions, 0. 
Construction.-If constructed of material that can be kept clean and sanitary allow 2; for fair construction, allow 1; poor construction, 0.

Equipment.-If well equipped with everytling necessary for the trade, allow 2; fair equipment, 1; poor equipment, 0.

Cleanliness.-If perfectly clean, allow 4 points; if conditions are good, 2; fair, 1 ; poor, 0 .

IVAGONS,

General appearance.-If painted and in good repair, allow 2 points; for fair condition, 1 ; poor, 0 .

Protection of Product.-If product is iced, allow 3 points ; well protected but not iced, 1 ; no protection, 0 .

Cleanliness.-If perfectly clean, allow 5; good, 3; fair, 2; poor, 0 .

The regulation of methods of pasteurizing milk is one of the newer problems that must be met in city inspection work. (See Appendix B.)

Milk-borne epidemics. Present methods of inspection do not prevent the occurrence of numerous epidemics of typhoid fever, diphtheria and scarlet fever. Much can be done in the way of recogniizing such outbreaks early, and in correcting conditions at the source of trouble. The health officer should investigate the milk supply, and other possible sources of infection, of all reported cases of these diseases, and keep a record of their distribution with reference to the various dairymen. When a dairyman shows a suspicious number of cases, due consideration being given to the size of his business and the general prevalence of the disease, the matter should be investigated. (See Chap. III.) Pasteurization (Chap. VI) seems to be the only way of preventing outbreaks of milk-borne disease.

The Department of Health of the City of New York has regulations requiring a report every week concerning the existence of infectious diseases among those handling milk. The dairymen are required to report to the manager of the shipping station and he in turn notifies the health department. Even if these regulations were uniformly obeyed they would not protect against bacilli carriers. (See Appendix D.)

Temperature standard. New York, Boston, and other cities require that milk be immediately cooled to $50^{\circ} \mathrm{F}$. or below, 
and that it shall not exceed this temperature before delivery. The requirement is desirable, and does not necessitate complicated methods of examination. This regulation very properly necessitates the use of ice at the producing farm, and the use of refrigerator cars where the milk is transported long distances. Its strict enforcement tends to eliminate the sale of milk from stores where adequate refrigerating facilities are not provided.

In a large area of the country, the Southern States and California, the universal enforcement of such a standard is out of the question because of the absence of natural ice. In large dairies, artificial refrigeration may be used, but the smaller producers could not afford the expense.

Numerical determinations of bacteria in milk. Bacterial counts may be made to yield valuable information when conditions that will permit the comparison of results are maintained. The first requisite is the practice of uniformity in technic. Under such conditions, the examination of the milk from time to time from samples of the same age will reveal significant deviations from the usual. Then an unusually high count will indicate the effect of the combination in some proportion of the factors of uncleanliness, age and poor cooling.

Numerical determinations of bacteria are an index of the care exercised in the handling of milk. A sufficient number of determinations give results that permit the classification of dairies in a general sort of way. Systematic counting of bacteria in a city milk supply encourages better methods. Relatively high counts occurring uniformly are unmistakable evidence of bad management.

Nice distinctions among dairies supplying a city cannot be made on the basis of a variation of a few million bacteria per cc. in the milk. The instrument of measurement is too delicate in such cases and the distinctions revealed too fine.

Effective work calls for faithful attention to details of technic and for numerous determinations. Tests made at rare intervals from samples of normally bad milk, varying considerably in age, represent the lowest degree of usefulness of the work. The sensational publication of such results does not materially 
protect the public or educate the dairymen. Unless bacterial counts are made carefully by competent persons from samples properly collected and cared for, they had best not be made at all. This is equally true in cases where the inspecting staff is too small or too inefficient to accomplish the work thoroughly.

In cities like Boston (10), Rochester (7) and Washington (15), bacterial counts in connection with inspection work have been made on a scale that has been regarded as productive of good results. The average bacterial count of the milk of Rochester declined in three years to one-fourth of the numbers prevailing before such work was undertaken (6).

The results of two years' work with a bacterial standard in Boston have been summarized as follows by Jordan (10):

TABLE VI.

NUMBER OF BAC'TERIA IN THE BOSTON MILK SUPPLY.

1905. 1906.

Sanples showing under 500,000 bacteria per cc. $87.60 \% \quad 89.98 \%$ Samples showing above 500,000 bacteria per cc. $12.40 \% \quad 10.02 \%$ Samples showing under 50,000 bacteria per cc. $59.80 \% \quad 62.33 \%$ Samples showing under 100,000 bacteria per cc. $74.90 \% \quad 72.67 \%$

As is usually the case, the determination of standards has been a matter of difficulty. They have been set on the basis of the justifiable assumption that germ free milk is the ideal milk. Then, after a survey of the conditions as regards numbers in the ordinary supply, a standard has been set low enough to interfere only with the worst producers. Boston set a limit of 500,000 per cc. for ordinary city supply, and has been pretty generally followed. Various finer grades of milk elsewhere have had higher standards, for instance, inspected milk, 100,000 per cc. Certified milk almost uniformly has a standard of 10,000 per cc. A bacterial standard need not be the subject of legislation, and the work may be merely carried on as a guide to inspection work. 
Bacterial counts take so long to carry out that they do not afford protection against the use of any given lot of highly polluted milk. An exception to this is afforded when Slack's method for the direct microscopic estimate of numbers is used. Ordinary counts do, however, discourage the habitual occurrence of such conditions. The method of making numerical determinations is described in Chap. VIII, and other laboratory methods are discussed in Chap. VII.

Education of the public. The general public must be informed concerning the significance of clean milk. The market for cheap, dirty milk must be destroyed as far as possible by the education of the public concerning its significance. Clean milk costs more, but people will not pay the increased price until they see the advantage. In matters concerning legislation and prosecution, the support of the public is desirable, if not indispensable.

The publication of the results of scoring dairies, showing their relative standing is a useful educational factor. This must be done circumspectly to avoid damage suits instituted by those dairymen who do not make a favorable showing. It seems safe to convey these facts in an official report, for instance, by the inspector or health officer to the board of health. This report may be given wide publicity in the press as a part of the proceedings of the board. Before going farther than this it would be well to determine the possible consequences.

Public education should include matters concerning the care of milk in the home, such as cleanliness of utensils, refrigeration, home pasteurization and the keeping qualities of pasteurized milk.

The agents for accomplishing educational work may include leaflets published by the board of health, the press, lectures before civic organizations, women's clubs, etc.

\section{REFERENCES.}

1. Bolton. Sanitary water supplies for dairy farms. 'Bul. No. 41, Hyg. Lab., U. S. Pub. Health and Mar. Hosp. Serv., Washington, D. C., 1908, p. 527. 
2. Borton. Methods and results of the examination of water supplies of dairies supplying the District of Columbia. Bul. No. 11, Hyg. Lab., I. S. Pub. Health and Mar. Hosp. Serv., Waslington, D. C., 1908 , p. 543 .

3. CONFER ENCE APPOINTED BY THE COMMISSIONERS OF THE DISTRICT of Columbia. Sanitary milk production. Cir. No. 11t, Bur. Anim. Ind., I. S. Iept. Agr., Waslington, D. C., 1907.

4. DARIINGTON. The methods of dealing with the milk supply of New York City. Jour. Amer. Med. Assoc., Vol. XIIX, 1907, p. 1079.

5. Fraskr. City milk supply. Bul. No.92, Lniv. of Ill. Agr. Exp. Sta., Urbana, I11., 1903.

6. Golfr. The influence of the municipal milk supply upon the deatlis of young children. $N$. Y. State Jour. of Med., Vol. III, 1903. p. 493.

7. Goler. Does the bacterial content of city milk influence the infantile death rate? Archiz. Ped., September, 1906.

8. Heinemann. Sanitary milk. Arch. Ped., June, 1908.

9. JAFFA and WARD. Investigations of the San Francisco milk supply. Nineteenth Biennial Report of the State Board of Health of California, p. 122.

10. 'Jordan. Boston's campaign for clean milk. Jour. Amer. Med. Assoc., Vol. XIIX, 1907, p. 1082.

11. LANE; and WEL, A city milk and cream contest as a practical nethod of improving the milk supply. Cir. No. 117, Bur. Anim. Ind., I. S. Dept. Agr., Washington, D. C., 1907.

12. LEvy. Monthly Bulletin of the Health Department. Richmond, Va., Vol. II, 1908, No. 4.

13. MaYor's Mirk Commission. Report on the milk supply of New York City, with recommendations. Arch. Ped., February, 1908.

14. RAYNOR. What rigid inspection of milk is doing for New York City. N. Y. State Jour. of Med., Vol. VIII, 1908, p. 252.

15. Rosenau. The number of bacteria in $m i 1 \mathrm{k}$, and the value of bacterial counts. Bul. No. A1, Hyg. Lab., U.S. Pub. Health and Mar. Hosp. Serv., Washington, D. C., 1908, p. 421.

16. Trumian. Milk supply of Chicago and twenty-six other cities. Bul. No. 120, Uniz'. of Ill. Agr. Exp. Sta., Urbana, I11., 1907.

17. WEBSTER. Sanitary inspection and its bearing on clean milk. Bul. No. 41, Hyg. Lab., U. S. Pub. Health and Mar. Hosp. Serzl, Washington, D. C., 1908, p. 511.

18. WoODWARD. The municipal regulation of the milk supply of / the District of Columbia. Bul. No. 41, Hyg. Lab., U. S. Pub. Health and Mar. Hosp. Serv., Washington, D. C., 1908, p. 679. 
CHAPTER II.

\section{PASTEURIZATION OF MILK.}

General definition. Pasteurization is a generic term referring to various processes of heating milk, followed by cooling. The temperatures involved vary from $140^{\circ} \mathrm{F}$. $\left(60^{\circ} \mathrm{C}\right.$. $)$ to $185^{\circ} \mathrm{F}$. $\left(85^{\circ} \mathrm{C}\right.$.) and the length of time of exposure to these temperatures varies from a few seconds to thirty minutes. A considerable number of pasteurizing machines designed to accomplish the heating of the milk in various ways are in use, and in actual practice do their work with varying degrees of uniformity. The temperature to which the milk is finally cooled, an important factor in the efficiency and value of the process. likewise varies. Another element leading to diversity of results is the bacteriological quality of the milk treated by the processes. Notwithstanding the widely differing processes designated by " pasteurization," the term unfortunately is constantly used without qualification to indicate the precise process designated.

Sterilization, a term frequently used in the discussion of the subject of heated milk, properly refers to a process by which all bacteria and their spores are killed by heat. This in connection with the preservation of milk involves an exposure to heat above the boiling point. It is employed in the preservation of canned nill $\mathrm{k}$ and never in connection with ordinary market milk.

Incentives for pasteurization. The destruction of pathogenic bacteria has been the chief incentive to the development of pasteurizing processes. The effect of heating in enhancing the keeping quality of milk is a valuable result which also has stimulated interest in the process. Methods for preserving milk are not necessarily the same as for killing pathogenic bacteria, although the converse is true. 
Conditions required for killing bacteria. Temperature and time of exposure are important factors with reference to methods of killing bacteria by heat. A high temperature for a short time is equally as efficient as a lower temperature for a longer time.

Bacterium tuberculosis. This is the most common of the pathogenic organisms found in milk, and at the same time the one of them most resistant to heat. Therefore it has been used as a basis for determining methods of pasteurizing, with proper regard to other considerations not concerning bacteria. The fact that $140^{\circ} \mathrm{F}$. $\left(60^{\circ} \mathrm{C}\right.$.) for twenty minutes is fatal to Bacterium tuberculosis is abundantly confirmed $(13,16,20)$. This is .equally true of the other pathogenic bacteria like $B$. diphtheria and B. typhosus, occasionally disseminated in milk (13).

To kill the tubercle bacterium, when the time of exposture of heat is shortened to one minute or less, the temperature must be $160^{\circ} \mathrm{F} .\left(71^{\circ} \mathrm{C}\right.$.) or more $(6,18)$. B. diphtherice (13) and $B$. typhosus (9) are destroyed in like manner.

-Alteration of milk by heat. The bacteriological requirements are by no means the only factors in the problem, for the heating of milk presents a formidable array of obstacles that must be avoided in formulating pasteurization processes. These involve all sorts of considerations, from those concerning the chemical constitution of the heated milk with respect to nutrition, to the practical requirements of the milk trade.

Cooked taste. This is left permanently in milk by exposure to about $158^{\circ} \mathrm{F}$. $\left(70^{\circ} \mathrm{C}\right.$.) for fifteen minutes. Exposure to $170^{\circ} \mathrm{F}$. $\left(76.6^{\circ} \mathrm{C}\right.$.) in a closed vessel, followed by immediate cooling, is the highest temperature that may be used without leaving the cooked taste. Ten minutes at $160^{\circ} \mathrm{F} .\left(71^{\circ} \mathrm{C}\right.$. $)$ is safe.

Alterations of milk constituents. The chemical constitution of milk is not appreciably altered by exposure to $140^{\circ} \mathrm{F} .\left(60^{\circ} \mathrm{C}\right.$. $)$ for a short time. At about $140^{\circ} \mathrm{F}$., milk heated with exposure to air forms a thin pellicle on the surface, consisting of casein and albuminoid matter. This is probably due to the drying of the upper layer of the milk and does not occur in closed vessels. Higher temperatures, especially near the boiling 
point, bring about profound changes. The significance of these, in connection with the digestibility of the altered constituents, has been widely discussed. Important manifestations of the effect of heat on milk concern temperatures higher than those necessary for pasteurization.

Creaming quality. Exposure to heat above certain limits so alters the physical constitution of milk that the cream does not rise 11aturally but remains more completely emulsified. The public judges milk largely by the amount of cream that rises, especially in the case of bottled milk where the location of the "cream line" is so easily detected. The sane causes that operate in this regard in milk affect market cream. The "body" is lessened, the cream looks of a poorer quality than it really is, its whipping quality is affected, and consequently its salability is impaired. These are weighty considerations and the application of heat must conform to them. Exposure to $160^{\circ} \mathrm{F}$. $\left(71^{\circ} \mathrm{C}\right.$.) for one minute, or long exposures at $140^{\circ} \mathrm{F}$. $\left(60^{\circ} \mathrm{C}\right.$.) are both safe $(2)$.

Vital qualities of milk. Milk has certain rital qualities, whose sensitiveness to heat deserves especial consideration with respect to the use of heated milk as infant food. Among these are the proteolytic, oxidizing, and fat splitting ferments. Here, too, may be mentioned the alexins, according to Von Behring, and the agents causing the so-called "germicidal" phenomenon, probably agglutinins. An exposure to not more than $140^{\circ} \mathrm{F}$. $\left(60^{\circ} \mathrm{C}\right.$. $)$ for forty minutes avoids the impairment of all these qualities of milk $(3,5)$.

Spore-bearing bacteria. Spores of bacteria in milk are not killed by one exposure to heat unless it is above $212^{\circ} \mathrm{F}$. Any of the processes of pastetirization will fail to kill bacterial spores, that ordinarily constitute less than $1 \%$ of the bacteria present. The hygienic significance of spore-bearing bacteria in such small numbers in fresh pasteurized milk is of no consequence, and the fact of their survival has been of necessity ignored in formulating methods of pasteurization. Their significance in old pasteurized milk has been the subject of considerable discussion. The varying percentage of spores in different lots of milk results in the variation of the bacteri- 
cidal efficiency of a pasteurizing machine at different times, even if run under constant conditions.

Bactericidal efficiency. Russell (15) has shown that an exposure to $140^{\circ} \mathrm{F}$. $\left(60^{\circ} \mathrm{C}\right.$.) for twenty minutes results in the destruction of as great a number of bacteria as exposure to higher temperatures for the same time. The bacteria remaining alive after exposure to $160^{\circ} \mathrm{F}$. were in spore form, and were uninjured by the higher ranges of temperature. Milk which would ordinarily sour in two days would keep fresh for six days when pasteurized at $140^{\circ} \mathrm{F}$. for fifteen to thirty minutes (2). Over $99 \%$ of the bacteria were killed.

Low-temperature pasteurization. The various limitations to the application of heat for the purpose of killing bacteria permit the use of $140^{\circ} \mathrm{F}$. $\left(60^{\circ} \mathrm{C}\right.$. ) for twenty minutes. All the physical, chemical and bacteriological considerations involved favor the selection of this combination of time and temperature, for it presents the widest margin of safety from violation of the limiting conditions.

The earliest machines for accomplishing low temperature pasteurization embodied the idea of heating a definite quantity of $m i 1 k$, with proper agitation, to the required temperature, after which the milk was rapidly chilled. The principle of a reservoir, alternately filled and emptied, is common to many. In some, heating and chilling the milk are accomplished in the same chamber. The process of intermittent pasteurization in the reservoir type of machine necessitates considerable expense for labor and is slow. These considerations have largely prevented the general employment of the type of machine in question. There are no insurmountable difficulties in the way of the development of machines for accomplishing low temperature pasteurization at a rate of speed and low cost appropriate to the demands of milk distributers. There are now on the market machines designed to hold the milk at a given temperature for twenty or thirty minutes, and at the same time permit continuous operation. The milk is first heated and then passed through a "holding device" by which the desired temperature is maintained for the proper time,

The pasteurizing process may be carried out in the house- 
hold with kitchen utensils, it being necessary to purchase only a thermometer. The bottles of milk for individual feeding of the infant are placed in a covered vessel of water provided with some simple device, like a perforated pie tin, to keep the milk bottles from touching the bottom. The vessel and contents are heated on the stove until the water reaches $155^{\circ} \mathrm{F}$. The whole is removed and allowed to stand for half an hour, after which the bottles of milk are rapidly chiiled.

High-temperature pasteurization. The demand for speed and economy has been a factor in the development of pasteurization at high temperatures for a short time. The heating is accomplished in various styles of continuous-flow machines, in which the milk passes over heated surfaces in a thin layer. The range of temperature extends from $176^{\circ} \mathrm{F} .\left(80^{\circ} \mathrm{C}\right.$. $)$ to $185^{\circ} \mathrm{F}$. $\left(85^{\circ} \mathrm{C}.\right)$, and the time of exposure varies from a few seconds upwards. The momentary exposure to $176^{\circ} \mathrm{F}$. $\left(80^{\circ} \mathrm{C}\right.$. $)$ is considerably above that necessary to satisfy the requirement for killing tubercle bacilli. The higher limit has been found necessary to compensate for defects in the thoroughness with which the continuous-flow machines do their work. As a class the machines are defective, in that all the milk passing through may not be heated to the desired temperature. This is attributable to a fundamental characteristic of the behavior of fluids. The parts of the stream not in actual contact with the heated surfaces will flow more rapidly than those portions influenced by friction. The employment of a temperature as high as $176^{\circ} \mathrm{F}$. $\left(80^{\circ} \mathrm{C}\right.$.) violates conditions required for market milk in the United States, but the process is unobjectionable in milk used for butter-making and is extensively employed in Denmark for this purpose.

Commercial pasteurization. A modification of the foregoing method, by the use of the same types of continuous-flow machines, is quite generally used for the purely commercial purpose of preventing the souring of milk. It hides, and partially undoes, the results of filthy methods of production and poor care in shipment.

The temperatures vary from $140^{\circ}$ to $165^{\circ} \mathrm{F}$. $\left(60^{\circ}\right.$ to $74^{\circ} \mathrm{C}$.), more often the lower temperature, followed by rapid cooling. 
The time occupied by the milk in passing through the machine is varied at the will of the operator, from a fraction of a minute to two minutes. The fact that this method of treating milk has cone into practice without consideration of its effect upon the pathogenic organisms becomes evident when attention is paid to the literature on the thermal death point of the tubercle bacterium in milk at temperatures between $140^{\circ}$ and $160^{\circ} \mathrm{F}$. At $140^{\circ} \mathrm{F}\left(60^{\circ} \mathrm{C}.\right)$, the shortest length of time that has been found permissible is fifteen minutes (20). Heating milk to this temperature or even several degrees above for a minute or less is a long way from the conditions insuring the death of the tubercle organism. Hess (Ref. 9, Chap. IV) has noted the deficiencies of commercially pasteurized milk as regards destruction of tubercle bacilli. It is only when the temperature of the milk during the heating for brief periods approaches $160^{\circ} \mathrm{F} .\left(71^{\circ} \mathrm{C}\right.$. $)$ that evidence is found to justify the belief that pathogenic organisms are killed.

There seems, then, to be justification for placing confidence in a pasteurization process, as a means for destroying pathogenic bacteria, in which all the milk is actually exposed for half a minute, or even momentarily, to a temperature of $160^{\circ} \mathrm{F}$. $\left(71.1^{\circ} \mathrm{C}\right)$. The statement need not necessarily imply an adherence to that system of pasteurization for rendering milk safe as against a system employing lower temperatures for longer periods. Commercial high-temperature pasteurization has narrow limits of safety bounded, on the one hand, by alterations in the physical characteristics of the milk, and on the other hand, by the danger of not killing pathogenic bacteria. The temperature zone in question comprises $160^{\circ}$ to $165^{\circ} \mathrm{F}$., and therefore the possibilities of negligence in running the apparatus, or intentional lowering of the temperature for commercial reasons, are obvious. There is always the possibility that the machine in use may not heat all portions of the milk uniformly to the temperature desired.

Efficiency. Efficiency tests of pasteurization must be interpreted with care. The bacteria remaining should not be compared, with respect to either numbers or character, with those in unheated milk. The character of the organisms in 
heated milk, and the medium in which they are present, entirely preclude comparisons with ordinary milk showing a similar count.

Prescott (10) found in a series of 32 observations, from samples containing mostly less than a million, that a machine at an average temperature approximately $164^{\circ} \mathrm{F}$. attained an average percentage efficiency of $97.1 \%$. The bacteria remaining in the milk averaged 14,000 per $\mathrm{cc}$. and the average temperature of the pasteurized milk was $40^{\circ} \mathrm{C}$. Very bad milk, three to nine million, showed the high efficiency of $99.1 \%$, with an average of 55,090 per cc. left alive. In regular practice the conditions for highest efficiency were not always maintained. Russell (15) has summarized the results of a number of such tests made by himself and others.

Continuous-flow machines popular. The commercial interests have refused to adopt generally the discontinuous or tank type of pasteurizing machine for market nilk, on account of expense and time consumed, although it is used for cream. The rapid, cheaply operated, continuous flow machine, running at $140^{\circ}$ to $165^{\circ} \mathrm{F}$., is a factor in the market milk business to-day. Lederle (8) estimates the expense of treating milk by this process to be from one-tenth to one-quarter of one cent per quart. However much bacteriologists may prefer the use of $140^{\circ} \mathrm{F}$. for twenty minutes, the other practice is deeply rooted. It has been estimated that one-quarter of the milk sold in New York is pasteurized and about one-third of that in Boston (12).

Under the circumstances, it seems that a fruitful field for persuasive educational effort is furnished by those instances where the machine is so run that the milk is exposed too short a time at a temperature below $160^{\circ} \mathrm{F}$. It is entirely possible to expose milk to $160^{\wedge} \mathrm{F}$. for a minute or even two, without injuring the cream line or flavor, although it probably does impair certain vital characteristics. Effort should be made to have the machines run at $160^{\circ} \mathrm{F}$. with the flow of milk slow enough to permit exposure to the heat for at least one minute. Better yet, the employment of machines heating to $140^{\circ} \mathrm{F}$. for twenty or thirty minutes should be encouraged. 
Care subsequent to heating. The milk must be rapidly and thoroughly chilled after heating. The process of pasteurization should include cooling to at least $50^{\circ} \mathrm{F}$., and any regulations defining the process should make reference to the cooling. Unless cooled, the few bacteria that have survived the heating will nultiply in the warm milk at an enormous rate. Any opportunities offered for contamination subsequent to heating will speedily undo the beneficial work done by the heat. The method of handling pasteurized milk for infant feeding illustrates an ideal way of avoiding subsequent contanination. The milk is pasteurized in the containers from which the baby is fed.

In connection with this subject, interest attaches to some recent amendments to the sanitary code of the Board of Health of New York, as follows:

“1. Pasteurization of milk must be carried out under a permit therefor issued by the Board of Health, in addition to the usual permit for milk required by Section 56 of the Sanitary Code.

“'2. The milk after pasteurization must be at once cooled and placed in sterilized containers, and the containers sealed.

“3. All pasteurized milk must be delivered to the consumer in sealed containers which are plainly labeled 'pasteurized.' 'The labels must also bear the daty and hour when the pasteurization of the milk was completerl, the degree of the heat enployed, the length of time exposed to the heat, and the number of the pasteurization permit issued by the Board of Health.

"4. Pasteurized milk must be delivered to the consumer within twentyfour hours of the pasteurization.

"5. No milk shall be pasteurized a second time."

Pasteurization in Chicago. Recent legislation in Chicago requires not only the pasteurization of all milk obtained from non-tested cows but also requires that all butter, cheese, buttermilk, cream and ice cream shall be derived from pasteurized milk unless the cows are free from tuberculosis. A number of new administrative difficulties are involved, such as inspection of pasteurization, and results of the experience with the Chicago ordinance will be awaited with interest. See Appendix B. 
Pasteurized milk in infant feeding. The use of heated milk for infant feeding is widely prevalent. There is abundant medical testimony to the effect that properly heated $m i l k$ is harmless, and that the general adoption of its use is an important factor in saving life (12). On the other hand, experienced specialists in pediatrics vehemently object to the long-continued use of heated milk for infant feeding and point with truth to cases that are unable to tolerate heated milk.

The literature of the subject is voluminous, but the discussion in general has not been concerned with clear-cut issues. The temperatures to which milk has been exposed in the past, and even now, are higher than necessary. All sorts of temperatures have been used and insufficient distinction has been drawn between sterilized and pasteurized milk. Reference has been made to the possible effect of toxins of bacterial origin remaining active in heated milk, but really very little is known concerning them. It has been asserted that the few sporebearing bacteria surviving the heating would subsequently multiply very rapidly with harmful effect. It has been shown however that, with proper refrigeration, multiplication goes on slowly (11). The issues to be determined havè been clouded by the interjection of ideas regarding the effect that the general practice of pasteurizing would have on the care exercised by producers. The writer is not yet convinced that there is a strong case against the use of milk heated to $140^{\circ} \mathrm{F}$. for twenty minutes. Now that this desirable kind of pasteurization is in, use, it would be well to take up on a large scale the study of the effect of this milk upon infant morbidity and mortality, as compared with unheated milk. The whole controversy concerns only the effect of heated milk on children of less than three years of age. There are special agencies for the supply of milk for infant feeding, and more will be provided in the future. Under these conditions, one may very well question the advisability of viewing the whole problem of municipal milk inspection from the standpoint of its use for the few infants who are unable to tolerate heated milk. Rosenau (12) discusses the matter fully. 
Pasteurization of municipal milk supplies. The subject of the pasteurization of milk assumes great importance in connection with the transmission of epidemic diseases of man. There has been collected a formidable list of instances in which milk has transmitted scarlet fever, diphtheria and typhoid fever. The work in Washington shows that $10 \%$ of the typhoid fever cases are plainly attributable to milk. In that city, of the dairymen delivering oyer 100,000 gallons of milk during the summer months, the one having the lowest typhoid fever rate among his customers has a thoroughly up-to-date system of sterilizing bottles and of pasteurizing milk by a holding-device type of machine.

The system of dairy inspection of the District of Columbia is not preventing milk-borne typhoid fever. All that can be done is to detect outbreaks as early as possible, correct the conditions at the clairy, and count the cases of typhoid fever as they continue to appear. This is not said in clisparagement of the Health Department of the District government, for it is under able, conscientious management.

The facts brought to light in Washington regarding typhoid fever alone indicate the necessity for pasteurization, and if subsequent work elsewhere brings to light similar conditions as regards this and other milk-borne diseases, the evidence for the necessity of pasteurization will be overwhelning. Certain it is, that pasteurization offers the only effective measure that may be inmediately put in force against the danger from bovine tuberculosis. That disease is so widely prevalent that the rigid application of measures against the sale of milk from tubercular cows without the alternative of pasteurization would cause a milk famine.

There have been opinions expressed to the effect that pasteurization would discourage the exercise of cleanliness and care of milk by the producers. This need not be worse than at present if inspection methods are thorough. As a matter of fact, pasteurization is not lessening the demands for care in producing milk. A number of instances could be pointed out of dairymen who pasteurize but keep the producers up to a high standard by counting the bacteria in the milk and by a private inspection service. 


\section{REFERFNCES.}

1. DOANE and PRICE. The comparative digestibility of raw, pasteurized and cooked milk. Bul. No. 77, Maryland Agr. Exp. Sta., College Park, Md., 1901.

2. FARRINGTON and RUSSEI. Pasteurization of milk and cream at $140^{\circ}$ F. Sixteenth Ann. Rept., Agr. Exp. Sta. Lniz'. of W'is., Madiso11, Wis., 1899, p. 129.

3. FREFMAN. The ferments of milk and their relation to pasteurization. Jour. Amer. Med. Assn., Vol. XLIX, 1907, No. 21, p. 1740.

4. FREFMAN. Pasteurization: The advantages and disadvantages to the consumer. N. Y. Med. Jour., March 23, 1907.

5. Hippius. Biologisches zur Milclipasteurisierung. Jahrb. Kinderheilk., Bd. LXI, 1905, s. 365.

6. JENSEN, translated by LEONARD PEARSON. Fissentials of milk hygiene, etc. Philadelplia: J. B. Lippincott Company, 1909.

7. Jensen et Piattiner. De l'action du chauffage sur le lait de vaclie. Rev. Gén. Lait, 4e Année, 1905, No. 16, p. 561, etc.

8. LeDeri.e. Pasteurization of milk. Amer. Jour. Pub. Hyg., O. S. Vol. XVII, 1907, No. 2, (N. S. Vol. III, No. 3), p. 164.

9. PARK. Current misstaten1ents and fallacies regarding the milk and milk supply of New York City. Medical Record, Vol. LXXI. Marcli 23, 1907, p. 501.

10. PRESCOTT. The efficiency of conmercial pasteurization and its relation to the milk problem. Technol. Quar., Vol. XVIII, 1905, No. 3, p. 247.

11. ROGERS. The bacteria of pasteurized and unpasteurized milk under laboratory conditions. Bul. No. 73, Bur. Anim. Ind., L. S. Dept. Agr., Washington, D. C., 1905.

12. Rosenau. Pasteurization. Bul. No. 41, Hyg. Lab., L'. S. Pub. Health and Mar. Hosp. Serz', Washington, D. C., 1908, p. 591.

13. Rosenau. The thermal death points of pathogenic micro-organisms in 11ilk. Bul. No. 42, Hyg. Lab., L. S. Pub. Health and Mar. Hosp. Serv., Washington, D. C., 1908.

14. Rotch. Pasteurization of milk for public sale. Amer. Jour. Pub. Hyg., O. S. Vol. XVII, 1907, No. 2, (N. S. Vol. III, No. 3), p. 181.

15. Russei.l. Outlines of dairy bacteriology. Madison, Wis.: H. L. Russell.

16. RUSSELL and HASTINGS. Thermal deatl point of tubercle bacilli under commercial conditions. Seventeenth Ann. Rept., Agr. Exp. Sta. Univ. of Wis., Madison, Wis., 1900, p. 147. 
17. Russeir. and Hastings. On the increased resistance of bacteria in milk pasteurized in contact with air. Eightecnth Ann. Kept., Agr. E.rp. Sta. Cniz' of Wis., Madison, Wis., 1901, p. 185.

18. RUSSEL and HASTINGS. Effect of short periods of exposure to heat on tubercle bacilli in milk. Twenty-first Ann. Rept., Agr. Exp. Sta. Lniv. of Wis., Madison, Wis., 1904, p. 178.

19. RUSSII, and Hoffyann. Bacteriological examination of milk pasteurized in Miller apparatus. Twenty-second Ann. Rept., Agr. Exp. Sta. L'niv' of Wis., Madison, Wis., 1905, p. 236.

20. Smirh. The thermal death point of tubercle bacilli in milk and some other fluids. Jour. Exper. Med., Vol. IV, 1899, No. 2, p. 217.

21. Spargo. The common sense of the milk question. New York: The Macmillan Company, 1908. 


\section{CHAPTER V'II.}

\section{MICROSCOPIC TESTS OF MILK.}

Mammitis in the cow. Cows very frequently suffer from mammitis associated with the presence of streptococci. The majority of dairies contain cows that show active inflammatory changes in one or more quarters of the udder. The abnormal product of such an udder always contains pus cells and streptococci. Clinical manifestations of the disease vary from the case exhibiting marked swelling of the udder, with a marked abnormal secretion, down through various gradations of clinical manifestations as exhibited through the condition of the udder or secretion, to the normal (34). More than this, bacteriological study of some apparently healthy udders reveals streptococci in the whole organ or in particular quarters of the udder. Sometimes in these cases"a history of a previous attack of mammitis may be established by inquiry or by the discovery of indurated portions of the udder by palpation, and other times not.

Tests for cellular content of milk. The development of microscopic tests of nillk has been actuated by a desire to determine quickly which cow's supplying city milk are suffering from garget and yielding pus cells and the accompanying organisms of suppuration. The exanination of a large number of milk samples in a city bacteriological laboratory by a fairly rapid, accurate method would perhaps obviate numerous visits to the dairies. In case of -positive restults, the dairies might be visited and inspected for udder disease or the milk of the individual animals in turn examined by the same test as a more delicate method than physical examination for selecting those cows yielding pus cells.

Stokes' test. Stokes (29) centrifugalized 10 cc. of milk, smeared the sediment on a cover glass and stained. When 
upon microscopic examination "an excessive amount of pus", was found in a sample of herd milk the examination of the individual cows was suggested. The presence of more than 5 pus cells per field of a one-twelfth objective in the milk of an individual cow was regarded as justification for the exclusion of the cow from the herd. The original article describing the test contained results of the examination of a series of cows, one-third of which were condemned on the basis of the standard selected.

Bergey $(3,4.5)$ found it necessary to lower the standard and regarded 10 cells per field as an indication of pus associated with inflammatory reaction of the udder caused by pyogenic organisms.

Stewart's test. Stewart (28), of the Philadelphia Burean of Health, further modified the method and applied it to the examination of large numbers of samples of mixed herd milk. He describes the apparatus and method as follows:

“'This apparatus consists of a circular pan about 12 inches in dianeter, and 3/4-inch deep, containing twenty small glass tubes. The tubes contain $1 \mathrm{cc}$. of nilik and are filled by means of a small bulb similar to that ordinarily used on medicine droppers. The end of the tube is closed by a small rubber stopper, and the tubes are held in the pan by spring clanns. This pan is fitted upon the ordinary Boekel water centrifuge and covered with a lid which is leld down by a thumbscrew. The pan covered in this way furnislies a 'surface of very slight resistance to the atmosphere during its revolution, somewhat on the principle of a clind's top.

"By the old method the arms of the centrifuge containing the 111ilk encountered so much resistance in their revolution that the speed with 15 pounds water pressure was not 111ore than 1,200 revolutions per minute, while the speed obtained with the new apparatus is from 2,500 to 3,000 revolutions per minute with 15 pounds pressure. This rapid speed causes sedimentation to occur in less than five minutes. When this is completed the centrifuge pan can be lifted frow the motor and the per cent. of crean measured by a graduated scale marked upon the tube. The heavier 111atter, as the insoluble dirt, pus cells and bacteria, is tlirown to the peripheral end of the tube, where it adheres to the rubber cork in the lumen of the tube. To examine this sediment, the cork is carefully removed and a spread made by rubbing the cork containing the sediment over an area of a square centimeter on a 3-inch by 6-incli glass slide. The proper area of the smear is obtained by placing underneath the slide a scale of circles having an area of a square centimeter. After the 
smears are dried in air without fixation by leat, the preparation is stained with the Jenner blood stain for two minutes, keeping the stain in constant 1110tion. The excess of stain is waslied off in water, and the preparation is dried in air. By this blood-staining methorl, the pus and blood cells are stained perfectly, and the ordinary microörganisns take the blue stain well.

"The stained specinens are exanined with a one-twelfth Leitz objective and a No. 3 eye-piece. The character of the bacteria is noted, and the average number of pus cells per field is counted. This average 11umber is multiplier by 4,400 , since there are about 4,400 fields to a square centimeter, as estimated by the stage nicrometer. This result is approximately the number of pus cells per cubic centimeter of nilk."

When a sample of milk showed over 100,000 cells per cc., or showed "streptococci and the ordinary pus producing organ-" isms," an examination of the herd was ordered. Stewart gave figures showing that inspections of condemned herds by veterinarians, revealed diseased animals in those herds.

The quantitative features of the test have not been found accurate. The average percentage variations between duplicate determinations have been found to be $112 \%$ in a series of 23 determinations made by Russell and Hoffmann $(23,24)$. The present writer and associates (32) also noted its very unsatisfactory behavior. The numerical results are always very much below the true number present and bear no constant ratio to the true number.

The test very rarely indicates the presence of streptococci, even though streptococci are proven by other methods to be very common in the milk. The presence of insoluble detritis, blood, etc., is indicated by the test.

Slack's test. Slack (26) modified the Stewart method by using tubes of a larger bore containing 2 cc., and smeared the sediment over 4 square centimeters. He further lowered the standard to 50 cells or over per one-twelfth oil immersion field, as warranting the condennation of milk. When streptococci are found in the sediment, he condemns for them alone if these three conditions are fulfilled:

1. Microscopic examination of sediment shows streptococci, diplococci, or cocci. 
2. A plate culture shows colonies resembling those of streptococci, in excess of 100,000 per cc.

3. From ten to fifty of the colonies are transferred to broth and grow1 24 hours at $37^{\circ} \mathrm{C}$. after which the broth cultures show streptococci alone or in great excess of other bacteria present.

Slack utilizes the test also for the direct microscopic estimation of the number of bacteria present.

Doane-Buckley test. Doane and Buckley (10) have devised a test which has been somewhat improved upon by Russell and Hoffmann (8). The technic given below is that described by the latter writers :

\section{COLLHCTION OF SAMPLE.}

Sample for analysis slould be taken from the entire milking of the animal, as the strippings contain a somewliat larger number of cells than other portions of the milk. For the purpose of examination take $200 \mathrm{cc}$. in stoppered bottle.

\section{Time INTERVAL, Between Col,ifetion and ANAlysis.}

To secure satisfactory results, milk nust be exanined in a sweet condition. Development of acidity tends to precipitate casein in the milk. and thus obscure the examination of microscopical preparations. Samples received from a distance can be preserved for satisfactory microscopical examination by the addition of formalin at time of collection,proportion of $1 \mathrm{cc}$. to $250 \mathrm{cc}$. of milk. Formalin has been found the best preservative to use, although it causes contraction of the cells to some extent.

PROCEDURE With RFFERENCE TO PREPARATION OF SAMPI,

\section{Heating Sampi,e.}

To secure the complete sedimentation of the cellular elements in the milk, it is necessary to heat the same to a temperature which will break down the fat globule clusters, or lessen the ordinary creaming properties of the milk. Samples should be heated at $65^{\circ}$ to $70^{\circ} \mathrm{C}$. for not less than ten ininutes, or from $80^{\circ}$ to $85^{\circ}$ where very short periods of exposure (one minute) are given. This treatment causes the more homogeneous distribution of the fat globules through the milk, and when the sample is then subjected to centrifugal force the cell elements are not caught in the rising fat globules, but on account of their higher specific gravity are concentrated in the sediment by centrifugal force. 


\section{CONCENTRATION OF Chitulat FithMENTS.}

Ten cc. of 1111k are placed in an ordinary sedinentation tube, and after heating as above directed, and subsequently sliaking, the n11ik is centrifugalized twenty minutes at 1,200 revolutions per minute. A land centrifuge may be einployed for this purpose, but where available a stean turbine Babcock milk tester may be found more practicable.

Note.-This speed, maintained for the time nentioned, is sufficient to sedinent practically all the cell elenents suspended in the milk. In our experience we have found the number of cells in supernatant $111 \mathrm{k}$ to average only $3 \frac{1}{2}$ per cent.

\section{PREPARING THE SAMPI,E FOR EXAMINATION.}

After centrifugalizing, the cream and the supernatant milk are removed, with the exception of the last half cc. by aspirating with an exhaust pump and wiping the walls of the tube with a cotton swab. After thoroughly mixing the sediment with a glass rod, enough of the enulsion is placed in an ordinary blood counter (Thonna-'/eiss pattern) to fill exactly the cell. The preparation is then allowed to stand for a minute or two to permit the cellular elements to settle to the botton of the cell, while the few fat globules in the liquid rise to the surface. This niethod permits of the differentiation of the cells from the small fat globules, so that a distinct nicroscopic observation can be n11ade.

\section{EXAMINATION OF MATERIAL.}

The preparation is exannined in an unstained condition.

NoTE.-Most observers have usually stained the sediment prior to examination, but we lave found with the above treatnent that the cells may be enumerated quite as well in an unstained as a stained condition.

The count is made with a 1 -inch eye-piece and $\frac{1}{6}$ objective. Where the number of cell elements exceeds 12 or 15 per 111icroscopic field, above referred to, one-fourtl of the entire ruled area of the counter, equivalent to 100 of the smallest squares of the cell, are counted. Where the cell elements are less abundant, one-half of the cells in the entire area (two to four hundred squares) are enumerated. The average number of the cells per smallest square is then obtained, which, when nultiplied by 200,000 , gives the number of cells per cubic centineter in the original milk. (If multiplied by $4,000,000$, we have the number of cells per cubic centimeter in the sediment examined. As the sediment represents the concentration of the cells into one-twentieth of the original volume of milk taken, $10 \mathrm{cc}$. to one-half cc., this number should be divided by 20 to give the number of cells per cubic centineter in the original milk.)

No'te.-The above factor of $4,000,000$ is obtained as follows: The cubic content of the blood counter represents one-tenth of a cubic centimeter. This volume is divided by means of the ruled scale into 400 small cubes, each equal to one four-thousandth of a cubic millineter, or one fourmillionth of a cubic centimeter. 


\section{EXPRESSION OF RHSUTAS.}

All results should be expressed in numbers of cells per cubic centimeter of the original milk, and in order to avoid fictitious accuracy, should be given in accorlance with the method adopted by the Committee on Standard Methods of IVater Analysis, as reporterl in this Committee's report to the Iaboratory Section of the American Public Health Association for 1905, page 94 .

The test has been shown to give results, on duplicate determinations, with a percentage variation of only about $6 \%(23)$. Thus we have a test of excellent precision that already has added valuable facts to the knowledge of the subject of leucocytes in milk.

The test has not been widely applied in practice, because of the difficulty in formulating a standard. A cellular content varying from 100,000 to 400,000 per cc. is common in normal cows, and even counts of 1,000,000 per cc. are encountered. A series of determinations of the lencocytes in the milk of 102 healthy cows showed an average of 241,000 per cc. This range of counts considerably overlaps the range of counts exhibited by cows with noticeable udder trouble.

Under the circumstances, the milk of a diseased cow with a count of a few millions is so diluted in the milk of the healthy cows showing relatively high counts, that the leucocyte content of the mixed milk is not raised.

Savage's test. Savage (25) has developed a very similar test. One cc. of milk is diluted with $20 \mathrm{cc}$. of 'Toisson's fluid and centrifugalized for ten minutes at about 1,800 revolutions per minute. The cream is then agitated with a glass rod and the whole again centrifugalized for ten minutes, and the supernatant fluid is drawn off to the $1 \mathrm{cc}$. mark. The remaining $1 \mathrm{cc}$. is thoroughly mixed and the number of lencocytes determined by the use of the Thoma-Zeiss blood counter. This, like the Doane-Buckley test, shows high numbers of leucocytes, and the same difficulties in setting a standard are encountered.

Trommsdorff's test. 'Trommsdorff $(22,30,31)$ arrives at conclusions regarding the number of cells in milk by measuring the amount of sediment obtained by centrifugalizing. Five cc. of mixed milk is centrifugalized for some minutes at 1,200 revolu- 
tions, and the amount of sediment is noted. For this purpose there is used a special centrifuge tube with the bottom drawn out into a capillary tube, properly graduated. These tubes are prepared by Franz Hugershoff, Leipzig.

The mixed milk of cows with sound udders, as a rule, shows sediment varying from traces to $.5 \mathrm{cc}$. per liter, with $1 \mathrm{cc}$. per liter as the maximum. On the basis of the examination of hundreds of mixed milk samples, it is asserted that when the test gives over 1 vol. per mille, it can be shown that one or more quarters of the udders of the cows are giving milk with an excessive number of cells.

The test is recommended by Trommsdorff as an aid in the diagnosis of chronic mammitis. He applied it to the individual cows in a dairy of good reputation producing milk for infant feeding. On three different occasions within a period of four months, he designated as diseased $20 \%$ on first test, $34.2 \%$ the second, and $27 \%$ on the third examination. The number of cows tested on the three occasions varied from 35 to 38 . In another dairy of $66,12 \%$ were considered diseased; in another of 75, 4\%; and in another of 82 cows, $19.5 \%$.

The test is said to give identical results from duplicate determinations. The criticism has been made that it is a measure not merely of lencocytes, but also of all substances that might be centrifugalized down into a sediment.

Significance of results. There has been a wide variation in the amount of importance that has been attached to the results of these tests. In some cases their tentative nature has been very properly recognized and the results used as indication of the desirability of an examination of the udders of the cows.

But instances are not rare of cases where the milk of a dealer has been publicly condemned on the ground of its containing pus, staphylococci and streptococci. There are instances, too, where the tests have been applied to the individual cows of dairies. Excessive and unreasonable numbers of cows have been condemned on the basis of the results where no symptoms of mammitis have been present. The condemnation of the majority of the cattle in a herd certainly focusses attention upon the evidence warranting such a procedure. 
The study of the subject has proceeded in the wrong order. The abnormal has been studied, tests devised and standards set, all from that standpoint. The use of checks to prove the value of tests has been too frequently disregarded. For instance, tests have been advocated as of value in detecting the location of diseased animals, without evidence being brought forward to show that the test has been tried on a group of animals known to be diseased. The detection of diseased animals in the herds supplying condemned milk has been accepted as confirmation of the value of a test.

The work has resulted in directing attention to the normal, which has often been too little considered. At present, the matter is in that period of development in which the fairness of standards and the accuracy of tests are being scrutinized. In judging the merits of the various tests, a number of facts concerning the normal must be considered.

Streptococci in milk Examination of samples of market milk will show streptococci in a very large percentage of the cases $(13,14,15,16,19)$. Heinemann has asserted that "Bacillus acidi lactici is a myth," and that the common organism souring milk should be called Streptococcus lacticus.

Reference has already been made in Chap. I to the fact that an apparently healthy cow was found to harbor a pathogenic streptococcus in the udder for a considerable period of time. In consequence the animal might well be called a streptococcus carrier (21).

There are no generally accepted methods for differentiating the various species of the genus streptococcus found in milk. It cannot at present be determined whether a given streptococcus is of human or animal origin, virulent or not, or whether it is a saprophyte. Hemolysis and agglutination have both failed to yield conclusive results (12). This group has been the despair of the systematists. Winslow and Winslow (33) give a valuable chapter upon streptococci.

Least of all, is it possible to make a differentiation on morphological grounds alone. Our ideas of the hygienic significance of the presence of streptococci, based on their rare discovery by certain tests, must be revised. 
Micrococci in milk. Micrococci (staphylococci), indistinguishable from Micrococus pvogenes, varieties aureus and albus, are normal inhabitants of the udder. Consequently, they are almost the characteristic organisms in the bacterial flora of fresh milk. Their close relationship to $M$. pyogenes aureus has been determined by thorough systematic study. They have been reported under this name by nunnerous observers, as noted in Chap. I.

The practice of reporting on the presence of pyogenic micrococci in centrifugalized sediments, fron microscopic examination, is certainly not justified.

Lencocytes in milk. Polymorphonuclear lencocytes may be demonstrated in the milk of any cow and must be regarded as a normal constituent of milk. As many as 200,000 per cc. in the milk of a cow may be considered common, and 500,000 per cc. not at all unusual. Sprague $(9,27)$ found the greatest

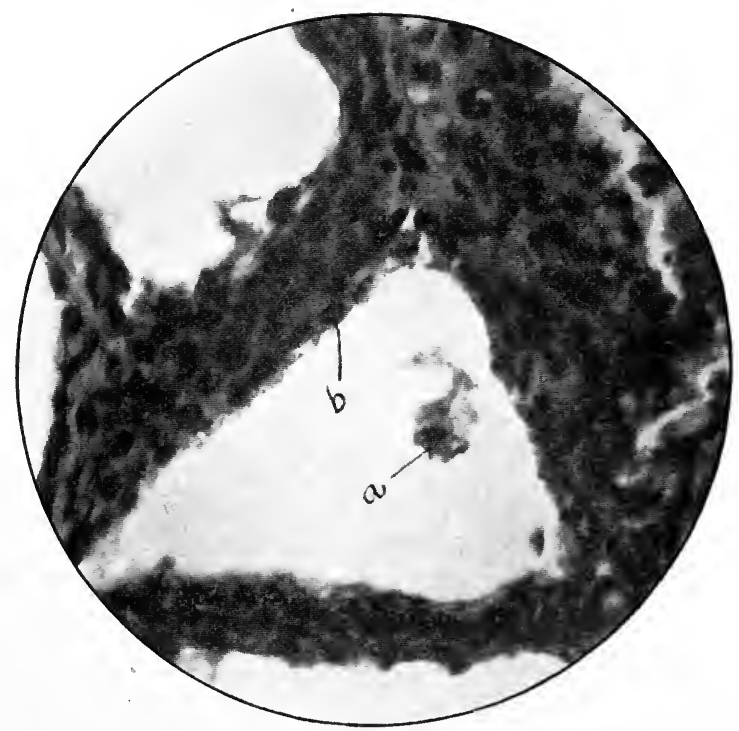

Fig. 15. Section of udder showing epithelial cells.

a. Fpithelial cell which has become loosened from the duct and is ready' to be carried out. b. Secreting epithelial cell in a'all of duct. a and b are of the same structure. 


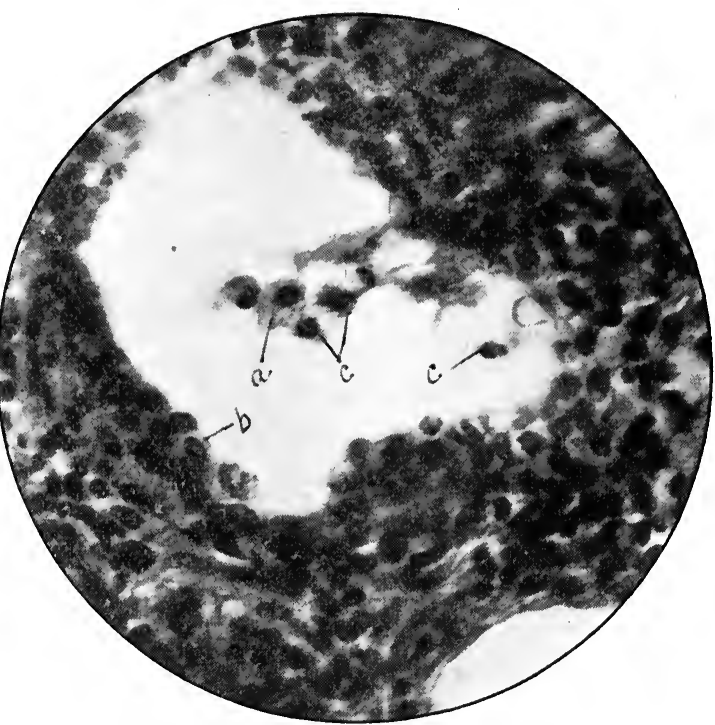

Fig. 16. Section of udder showing epithelial cells and polynuclear leucocytes.

a. Epithelial ce!l which has become loosened from the wall of the duct. similar to a in Fig. 15. b. Secreting epithelial cell in situ, being same in structure as a. c. Polynuclear leucocytes in ducts ready to be thrown out along with the loose epithelial cells.

variation among the cows of a herd examined by him. Some of the apparently healthy cows gave counts exceeding 500,000 per cc. It was not possible, however, to pick ten cows that would average more than that number. The leucocyte count of the milk of two apparently healthy cows was determined twice a day over a long period of time, and the most abrupt fluctuations were observed in the number of leucocytes present. Heated milk gives a much higher leucocyte count by both the Doane-Buckley and the smeared-sediment method (9).

Leucocytes and pus cells are identical, although common practice has determined that, under conditions of health, the cells in question shall be called leucocytes, and pus cells in certain pathological conditions. We have no satisfactory standard at present to determine when this change in designa- 
tion shall occur in the case of cells in milk. It has been suggested that this should be governed by the presence of streptococci, or fibrin, or red blood corpuscles with the cells in centrifugalized sediments. Besides the polymorphonuclears, there may be demonstrated in milk sediments large and small mononuclears and eosinophiles. Our knowledge of the source of these cells is incomplete as yet. Boynton and Russell independently have photographed sections of the functional, healthy udder, and by this means have shown the presence of leucocytes and other cells in the lumina of the lactiferous ducts in contact with the epithelium. Those by Boynton appear in Figs. 15 and 16. Very likely in connection with milk secretion epithelial debris is extruded in milk, even though the present trend of opinion denies that fat secretion is accomplished by fatty degeneration with the destruction of the cell $(1,2)$. The general leucocyte content of the blood of the cow seems to bear no relation to the leucocyte connt of the milk (8).

The centrifugalized sediment of milk has been known since the advent of the cream separator under the name of separator slime. The mass always collecting in the bowl of the separator has a disgusting appearance suggesting pus. On this account some dealers clarify their milk, that is, run it through a separator to remove this sediment and particles of foreign material. Here again is a case where a normal milk constituent has had its sanitary significance overrated, because defective tests ordinarily showed it to be present in small quantity.

Summary. Mammitis is very common among cows. The majority of dairies contain cows that show active inflammatory changes in the udder, or evidence of previous manifestations in the shape of indurations which might warrant the diagnosis of chronic mammitis. The discovery of diseased udders in a herd after the condemnation of the mixed milk by some test is therefore a fact of questionable significance in proving the value of the test.

In view of all these circumstances, it cannot be said that the matter of microscopic tests for cells in milk is yet on a satisfactory basis. Future work must be done on individual cows in determining the border line between health and disease. 
It would be well to study the milk of individual cows, preferably with known histories, with reference to the occurrence of leucocytes and streptococci. For leucocytes the Doane-Buckley test might be used, and for streptococci, numerical determinations. Histological examination of the udder may prove to be a reliable criterion for the determination of disease in experimental work.

The situation is very well summed up in the Preliminary Statement by the Committee on Standard Methods of Bacterial Milk Analysis to the Laboratory Section of the American Public Health Association, in these words:

"Since, however, evidence alrearly collected, warrants beyond all question the general statement that these cells frequently do not have the significance that has been attached to them by many observers, it would perhaps be more fair to all parties concerned to use this (leucocyte) test at present as a means of detection only, and not to condemn the supply unless physical lesions are demonstraterl. *** The standards so far chosen have been more or less arbitrarily selecter on what appears as rather inarlequate data, and from a comparison of results it is apparent that much more comparative work needs to be done."

The committee expresses a similar view in its 1908 report as follows :

"It is the opinion of the Committee that milks having high leucocyte content, unless accompanied by other indications of inflammation such as blood or virulent organisms, should not be condenned as unfit for use on the laboratory findings alone. Such milks may be regarded with suspicion and the laboratory findings may well serve as a guide for veterinary inspection.'

The writer rather doubts whether microscopic examination of milk will eventually prove a satisfactory means of protecting the public from streptococci in milk from diseased cows. When a satisfactory decision has been reached as to what constitutes a diseased udder in a cow and how to detect the presence in a herd of animals so affected, there remain administrative difficulties. The individuals in a dairy herd are constantly changing and the health of the udder is liable to variation from day to day, which necessitates very frequent examinations. Then there remains the difficulty of enforcing the exclusion of the milk of the condemned cow. A large American city of to- 
day is indeed fortunate if it has a corps of inspectors sufficient to permit visiting each dairy four times a year. The conditions existing and the difficulties of correcting them by inspection, lead one to doubt whether anything but pasteurization can give effective protection from streptococci.

Bloody milk. Slight injuries to the udder will sometimes cause the rupture of a blood vessel and result in the mixing of blood with the milk. The blood may be so small in amount as to escape notice by the milker. After delivery, when the cream rises, it will be distinctly pink. Microscopic examination of the cream will reveal red blood corpuscles. To detect the source of such milk, it may be necessary to collect a sample from each quarter of each cow's udder, in separate test tubes. The bloody sample may be detected in the test tube immediately after drawing, or certainly later after the cream has risen.

\section{REFERENCES.}

1. ARxol, D. Die Bedeutung der Fettsynthese, Fettphagocy tose, Fettsekretion und Fettlegeneration für die Milch- und Kolostrumbildung. Munch..Hed. Hchnschr., 52. Jahrg., No. 18, 1905, S. 841.

2. ARNOLD. The morphology of milk and colostrum secretion. Beitr. Path. Anat. u. Allg. Path., Bd. XXXVIII, 1905, No. 2, s. 421. Abs, in Exp. Sta. Rec, Vol. XVII, p. 495.

3. BERGEY. An investigation on the value of certain sanitary and other precautionary neasures, employed in the protection and marketing of milk, upon the bacterial contents of the milk. Penn. Nept. Agr . Rept., 1900, Part I, p. 133.

4. BERGEY. The cellular and bacterial content of cow's milk at different periods of lactation. I'niz'. Penn. Iled. Bul., Vol. XVII, JulyAugust, 1904, p. 181.

5. BERGEY. The source and nature of bacteria in milk. Bul. No. 125, Penn. Dept. Agr., 1904.

6. BERGEY. The leucocyte and streptococcus content of cow's nilk. Ĺniv. Penn. Med. Bul., September, 1907.

7. BRüNING. Investigations of market milk in·Leipzig with special reference to the presence of streptococci. Jahrb. Kinderheilk. Bd. IXII, 1905, No. 1, S. 1. Abst. in Exp. Sta. Kec., Vol. XVII, 1906, No. 5, p. 496. 
8. COMMITTEF OF THE LABORATORY SHCTION OF THF AMERICAN PUbiac Hral,th Association. Preliminary statement by the committee on standard methods of bacterial nilk analysis. Amer. Jour. Pub. Hyg., Vol. XVII, 1907, No. 4, N. S. Vol. III, No. 5, p. 331.

9. CoMMITTEF OF THF LABORATORY SECTION OF THF AMERICAN Pubic Healith Associaton. Report of progress, 1908. Unpublished.

10. DOANi. Leucocytes in nilk and their significance. Bul. No. 102, Maryland Agr. Exp. Sta., College Park, Md., 1905.

11. Fisns. Beitrag zur Kenntniss der Milch. Centbl. Bakt, etc., 2. Abt., Bd. XVIII, 1907, S. 428.

12. HARRIS. The relative importance of streptococci and leucocytes in milk. Jour. Infect. I)iseases, 1907, Supp. No. 3, p. 50.

13. Heinemand. The significance of streptococci in milk. Jour. Infect. I)iseases, Vol. III, 1906, No. 2, p. 173.

14. Huinfians. The pathogenicity of streptococcus lacticus. Jour. Infect. Diseases, Vol. IV, 1907, No. 1, p. 87.

15. Houston. The bacteriological examination of milk. Jour. Com. Path. and Ther., Vol. XIX, 1906, p. 145.

16. KaIser. On the streptococci in milk. Arch. Hyg., Vol. LVI, 1906, No. 1, p. 2.

17. Kuntze. Gewinnung keimarmer Milch. Centbl. liakt., etc, 2. Abt., Bd. XX, 1907-08, S. 420.

18. Mint,ER. The significance of leucocytes in milk. Bul. No. 71 , Hyg. Lab., I. S. Pub. Health and Mar. Hosp. Serí,. Washington, I.C., 1908, p. 479.

19. MëLlíR. On the streptococci in milk. Arch. Hyg., Vol. L,VI, 1906, No. 1, p. 90. Abst. in E.rp. Sta. Rec., Vol. XVII, 1906, No. 12, p. 1183.

20. Pennington and Roberts. The significance of leucocytes and streptococci in the production of a high grade milk. Jour. Infect. Diseases, Vol. V, 1908, No. 1, p. 72.

21. REED and WARD. The significance of the presence of streptococci in market milk. Amer. Hed., Vol. V, 1903, No. 7, p. 256.

22. Rutr,Man und TrommsnorfF. Milchlygienische Untersuclungen. Arch. Hyg., Bd. LIX, 3. Heft., 1906, s. 224.

23. RUSSEI, and HOFFMANn. Leucocyte standards and the leucocyte content of milk from apparently healthy cows. Jour. Infect. Diseases, 1907, Supp. No. 3, p. 63.

24. RUSSEL, and HOFFMANN. Distribution of cell elements in milk and their relation to sanitary standards. Truenty-fourth Ann. Rept. Agr. Exp. Sta., Lniv. of Wis., Madlison, Wis., 1907, p. 231. 
25. SAVAGE. Streptococci and leucocytes in milk. Jour. Hyg. (Cambrilge), Vol. VI, 1906, No. 2, p. 123.

26. SiACK. Methorls of bacteriological exanination of milk. Jour. Infect. Diseases, Supp. No. 2, February, 1906, p. 214.

27. Sprague. The leucocyte content of nilk. Bul. l't. State Board of Health, Vol. IX, No. 1, 1908, p. 44.

28. STEWART. Methorls employed in the examination of milk by city authorities. Amer. Med., Vol. IX, 1905, No. 12, p. 486.

29. STokss. The microscopic examination of nilk. Ann. Rept. Health Dept. Baltimore, 1897, p. 105.

30. Tromisdorfa. Munchen. Med. Hchnschr, 1906, No. 12, S. 541.

31. TrommsdorfF. Neue Methode zur Diagnose der chronischen, speziell der Streptokokenmastitis cler Kul. Berlin Tierar $z$ tl. Hchnschr.. 1906, No. 15, S. 281.

32. WARD, HENDERSON and HARING. The numerical determination of leucocytes in milk. Nineteenth Biennia! Rept. Cal. State Bd. Health, 1906, p. 142.

- 33. Winslow and Wissiow. The systematic relationships of the coccaceæ. New York : John Wiley and Sons. 1908.

34. ZsCHOKKk, transl. by WARD. Fxperinents in treating infectious mammitis in the cow. Am. L'et. Rer., Vol. XXY, 1901, No. 1, p. 9. 
CHAPTER VIII.

\section{BACTERIOLOGICAL EXAMINATION OF MILK.}

Numerical determination of bacteria. The diversity of methods in use in different laboratories is such that comparison of the numerical results obtained by them is quite out of the question. The water bacteriologists long ago recognized the undesirability of a diversity of methods in counting bacteria in water, and applied a remedy. The standard methods of water analysis suggested by the committee of the American Public Health Association have been favorably received. The results warrant and encourage further work towards the unification of other laboratory methods. A committee of the Laboratory Section of the American Public Health Association has in hand the task of formulating standard methods of bacterial milk analysis. The committee, consisting of F. H. Slack, chairman; W. H. Park, E. C. Levy, F. C. Harrison, C. E. Marshall and H. L. Russell, has been at work for two years, weighing the merits of the various methods in use. There have been submitted two preliminary reports, one in 1907 and one in $1908(3,4)$. The methods reported are not definitely selected as a final standard, but represent a consensus of opinion of American workers on the subject. The methods for the numerical determination of bacteria herewith recommended are a composite of the two reports of the A. P. H. A. Committee. The recommendations are substantially as made in the 1907 report, and the modifications made in 1908 are introduced and so indicated.

NUMERICAI, DETERMINATION OF BACTERIA.

There is no niethod known by which the exact number of bacteria in a sample of milk may be determined, and even when the best methods 
are used, the count is always less than the actual numler of bacteria present, for the following reasons :

(a) Many bacteria in process of multiplication are held togetler by arlhesive membranes in pairs, chains or masses. It is for the purpose of separating bacteria thus joined, as well as to obtain an even mixture, that the sample itself and the diluted sample when plating are shaken. This shaking, while it breaks up larger masses and shortens long chains, does not to any great extent break apart the shorter chains, cliplococci, etc. Eacl of these groups of bacteria, when caught in the solicl mediun, develops as a single colony.

(b) It is impossible to obtain a medium suited to the food requirements of all species or races of bacteria (2). (See foot-note.)

It has been found by experiment that a medium consisting chiefly of a watery extract of raw meat, alkaline to litmus and slightly acid to phenolphthalein, will furnish the best food for the greatest number (3).

(c) These varying forms of minute vegetable life require varying temperatures for their best development. Many forms which will develop at room temperature will not grow at boly temperature. Some require a very ligh temperature for their best growtl.

(d) Some bacteria develop in an atmospliere free from oxygen, some only where oxygen is present ; many are facultative growing under either condition. Bacteria which require an oxygen-free atmosphere do not develop in plates as generally prepared. Bacteria requiring oxygen, if deep in the medium, develop but slowly, as they obtain oxygen only by diffusion.

(e) Many forms are slow in developing into visible colonies, sone requiring three or four days. On the other hand, in plates grown for several days many small colonies are obscured in the growtl of larger ones (4).

(f) Each bacterium requires a certain anlount of nourishment for developinent (5). There are also antagonistic forms which will not develop in close proximity to each other. 'It therefore follows that in a crowded plate, i. e., over two liundred colonies, many will not develop (6). This is easily proven by making a higher dilution.

$(g)$ Spreaders and molds, by their rapid surface growth, merge with other surface colonies and obscure deeper ones.

(h) Samples kept in the collecting case at $34^{\circ} \mathrm{F}$. for varying periods have shown a tendency to decrease in the number of bacteria which will develop into colonies (7). Samples kept in dilution water for several hours have shown a marked decrease in the number of bacteria which will develop into colonies (8).

On account of these reasons strict adherence to standard procedure is of especial importance, since there are so many points where disagreement may result if uniform technique is not followed.

NotE.-The reference numbers occurring in the Committee report refer to the bibliography accompanying the same, appearing on page 150 . 
Since at best only approximate results can be reacled in the numerical determination of bacteria in milk, and since from the varying methods in use at present connts from different workers are usually incomparable, those methods which have given best results as a whole should be united npon and arlopted by all, that a bacterial count on a sanple of milk may mean the sane if made in any standard laboratory.

\section{COIJHCTION OF SAMPLES.}

Quantity of milk required for analysis. The minimum (quantity of n11k necessary for making an ordinary bacteriological exanination is ten cubic centinteters. When making examinations for certified nilk, if possible a pint or quart bottle should be taken and brought to the laboratory unopenerl.

Collecting apparatus. In collecting milk samples for bacteriological examination it is essential that the sample be taken and kept in such a manner as to prevent either any addition of bacteria from withont or multiplication of the bacteria originally present (9. Bottles, tubes, pipettes, etc., used in the collection of samples, besides being washerl, sliall be sterilized with dry lieat for an hour at or about $160^{\circ} \mathrm{C}$., or to the charring point of cotton.

In the selection of "certified nilk" samples it is recommended wherever possible that an unopened bottle be taken, placed in a suitably iced case and brought at once to the laboratory.

Samples of "market $1111 \mathrm{k}$ " may be collected as are water samples, in sterile, wide-moutherl, glass-stoppered four-ounce bottles; the case in which they are carried being well iced (10). The principal difficulty encountered in this method is in transferring the sample from the original container to the bottle, and the various string and wire devices by means of which the bottle is immersed in the original container are objectionable botli on account of the labor of preparing sucli an outfit and also on account of the coating of milk left on the outside of the bottle when the sample las been taken.

An apparatus designed for the use of thirty-two test tubes as containers (11) is recommended as superior to one designed for bottles.

It has been proven that with samples kept properly iced in this particular form of case there is no increase of bacterial content even for twenty-four hours, but ratler a slight decrease (7), the counts varying hardly more than might be expected in duplicate plates. It is recommended, however, that examination of the samples be proceeded with as quickly as possible after the collections are made.

Identification of samples. When bottles are used identification numbers should be etched on both bottle and stopper. Test tubes should be labeled or etched (12) and numbered.

A complete record of the samples taken, giving date, "time, place, name of party from which sample is taken, name of collector, tempera- 
ture of milk, character of original container (tank, can, bottle), etc., should be written opposite duplicate numbers in a blank book or pocket card catalogue, or this information may be written on snall tags and tied or wired to the corresponding test tube or bottle.

Temperature. The temperature should be taken inmediately after taking the sample for analysis, while the milk is still thoroughly inixed.

If it is desired to take the temperature of " certified milk, " this should be done when the sample is taken, but from another bottle.

A floating thermometer, graduated to the Fahrenheit scale, is most convenient, and the temperature should be expressed to the nearest degree. It is necessary to standardize the thermometer for at least ten degrees on each side of the legal temperature limit. A quickly registering thermometer should be left at least one minute in the milk and read as soon as renioved. A small piece of clean absorbent cotton may be used to wipe the adhering milk from the thermometer that the scale may be easily seen.

Representatize samples. The collector should always select his own sample, and care should be taken to secure a sanple which is truly representative of the milk to be examined.

One of several methods of mixing the milk may be used, comparison having shown the results to be practically the same (9).

1. Pouring the milk into a sterile receptacle and back.

2. Shaking the milk thoroughly with receptacle turned upside down. (This may be done where the can or bottle is tightly stoppered or capped and is not so full as to prevent thorough agitation.)

3. In open tanks in stores it is allowable to stir thoroughly with the long-handled dipper generally found in use.

4. Where the test tube collecting case is used, thoroughly reliable results are secured by first shaking the can or bottle; and, second, stirring with the large pipette before taking the sample, care being taken to close the upper end of the pipette with the finger so that no 11ilk enters until after the mixing, or the pipette may be emptied after stirring before the sample is taken.

5. For certified milk samples it is recommended that, on arrival at the laboratory, the bottle be opened with aseptic precautions and the milk thoroughly mixed by pouring back and forth between the original bottle and a sterile bottle. Another method is to mix as thoroughly as possible by agitation for five minutes, then burn througli the paste-board stopper with a hot iron and reniove tlie desired amount of milk witl a sterile pipette (13).

The interval between collection and analysis. Generally speaking the shorter the time between the collection and examination of milk samples the more accurate will be the results. For routine work the attempt should be made to plate within four hours of the time of collection.

Too much stress cannot be laid on keeping the samples properly iced 
during this interval. They should be kept below $40^{\circ} \mathrm{r}$., but care should be taken that they are not frozen.

\section{Dir.útrons.}

Ordinary potable water, sterilized, may be used for dilutions. Occasionally spore forms are found in such water which resist orclinary antoclave sterilization; in such cases distilled water niay be used or the autoclave pressure inereased. With dilution water in eight-ounce bottles calibrated for ninety-nine cubic centineters all the necessary dilutions can be made.

Slort, widle-111outhed "Blakes", or wide-111outhed French square bottles are more easily handled and more economical of space than other forms of bottles or flasks (11).

Fight-ounce bottles are the best, as the required anount of dilution water only about half fills then, leaving room for shaking. Long-fiber, non-absorbent cotton should be used for plugs. It is well to use care in selecting cotton for this purpose to avoid short-fiber or "dusty cotton," which gives a cloud of lint-like particles on shaking. Bottles and tubes should be filled a little over the $99 \mathrm{cc}$. and $9 \mathrm{cc}$. marks to allow for loss during sterilization (14).

The dilutions recommended are 1-10, 1-100, 1-1,000, 1-10,000, 1-100,000 and 1-1,000,000.

For certified milk the 1-10 and 1-100 dilutions should be used, while the 1-10,000 will usually be found best for niarket $111 \mathrm{k}$.

The 1-10 dilution is prepared by shaking the milk sample twenty-five times and then transferring $1 \mathrm{cc}$. of the $111 \mathrm{k}$ to a test tube containing 9 cc. of sterile water.

The 1-100 dilution is prepared in the sane way, except that a bottle with $99 \mathrm{cc}$. of sterile water is substituter for the test tube.

The 1-1,000 dilution is prepared by first making the 1-100 dilution, shaking twenty-five times and transferring $1 \mathrm{cc}$. of the dilution to a test tube containing $9 \mathrm{cc}$. of sterile water.

It is recommended that that dilution be used which will produce about two hundred colonies to a plate, ranging from 40 to 400 ; where a 1-10 dilution exceeds this number the 1-100 dilution is more accurate, etc. The number of bacteria present may if desired be approxinately esti. mated before dilutions are made by direct microscopic examination of a properly prepared sediment. Otherwise it is necessary to make a range of dilutions, thereafter selecting for record the count obtained on that plate which yields between 40 and 400 colonies.

Plating whole milk is unreliable (15), whatever qualities be used, since the bacteria are not so well separated as in the dilutions, and often, owing to the crowded conditions, only a portion of the bacteria present will develop into visible colonies (6). Moreover, if a cubic centimeter of the milk is used, the turbidity of the jelly, lue to the presence of the milk, hides the colonies present from the eye. 


\section{Minia.}

The standard medium for determining the number of bacteria in milk shall for the present be agar, made according to the reconmentations of the Comnintee on Water Analysis (1), except that the percentage of agar shall be 1 per cent. and the reaction $+1.5(2 \mathrm{~d})$.

Al1 variations from agar media made as described shall be considered as special media.

Much work yet reniains to be done on nlerlia; the above is recommenderl as giving the highest and most uniform counts as far as our connparative work has extended and with but slight variations is the medium in most connmon use.

Storage of media. Media may be marte up in quantity, tuber and stored (preferably in an ice chamber).

\section{PlatiNG.}

Plating apparatus (11). For plating it is best to have a single water - bath in which to melt the media and a water-jacketed water bath for keeping it at the proper temperature; a wire rack, which should fit both of the water baths, for holding the media tubes; a thermoneter for recording the temperature of the water in the water-jacketerl bath; sterile $1 \mathrm{cc}$. pipettes; sterile petri dishes; and sterile dilution water in measured quantities.

For $111 \mathrm{k}$ work porous earthenware petri dish covers (16), are 111uch superior to glass covers, since they absorb the excess moisture from the agar and prevent "spreading."

It is quite essential to the best results that the porous covers should be wet as seldom as possible. In sterilizing them the process should be prolonged over the tin1e necessary to kill the organisins in order that the covers may be thoroughly dry.

Extract from the 1908 report. A method of avoiding the troubles due to moisture consists of inverting the plates, and putting in the lid of each petri dish, a strip of blotting paper on which there is a large drop of glycerine. Incubate as directed.

As a result of these experinents we feel that the agar plates with glycerine, prepared in the manner above indicated, are slightly more reliable than the earthenware tops.

The principal objections to the latter are:

(1) They scratch the glassware.

(2) The plate has to be uncovered for exanination, and

(3) They are more liable to dry out if kept longer than 36 hours.

Straight-sided $1 \mathrm{cc}$. pipettes are more easily handled than those with bulbs ; they may be made from ordinary glass tubing about $\frac{3}{16}$ of an inch in dianeter and calibrated in the laboratory (17). They should be made about ten inches in length. 
Plating technique. The agar after nelting shonld be kept in the water-jacketed water bath between $40^{\circ} \mathrm{C}$ and $45^{\circ} \mathrm{C}$. for at least fifteen minutes before using, to make sure that the agar itself has reached the temperature of the surrounding water. If used too warm the lieat may destroy some of the bacteria or retard their growth.

For routine work in cities in order to bring down the actual number of colonies in a plate around the standard of two hundred, it is well to use a dilution of 1-10,000. To make this dilution use two bottles of sterile water each containing $99 \mathrm{cc}$.

Shake the 1nilk sample twenty-five times, then with a sterile pipette remove $1 \mathrm{cc} .$, put into the first dilution water and rinse the pipette by drawing dilution water to the mark and expelling; this gives a dilution of 1 to 100 .

Shake the first dilution twenty-five times, then with a fresh sterile pipette remove $1 \mathrm{cc}$, put into the second dilution water, rinsing the pipette to the mark as before; this gives a dilution of 1 to 10,000 . Shake the second dilution twenty-five times, then witl a sterile pipette remove $1 \mathrm{cc}$, and put it into the petri disl, using care to raise the cover only so far as necessary to insert the end of the pipette.

Taking a tube of agar from the water bath, wipe the water from outsicle of tube with a piece of cloth, remove the plug, pass the 1nouth of the tube through the flame, and pour the agar into the plate, using the same care as before to avoid exposure of the plate contents to the air.

Carefully and thoroughly mix the agar and diluted nilk in the petri clish by a rotary notion, avoiding the formation of air bubbles or slopping the agar, and after allowing the agar to harden for at least fifteen minutes at room temperature place the dish botton down in the incubator. The practice of mixing the diluted milk with the agar in the tube, leaving a certain portion of the bacteria unplated, is not recommended by the Committee.

Controls. Plating should always be checked by controls. A blank plate should be made with each set of milk plates for control of the water, petri dishes, pipettes, etc.

For control on teclinique of plating it is recommended that for work on "'narket milk," cluplicates be made each day on several plates.

" Certified milk" should always be plated in duplicate, and where possible it is well to have one 111an's work occasionally checked by another.

Unless duplicate plates show as a rule approximately the same count, the worker should see if there is error in his technique.

Racks are very useful for stacking the plates and to prevent breakage.

Plating should be done always in a place free from dust or currents of air.

In order that the colonies may have sufficient food for proper development, $10 \mathrm{cc}$. of agar shall be used for eaclı plate. In plating a large number of samples at one time the dilution and transfer of diluted 1nilk 
to the plates nuy be done for four or eight samples, then the agar poured, one tube to each plate, then another eight samples liluted, etc.

\section{INCUBATION.}

Methods. Concerning incubation two methods are at present in use. Three-fifths of the laboratory workers consulted recommended incubation at $37^{\circ} \mathrm{C}$. for twenty-four hours with saturated atmosphere, the remaining two-fiftlis allowed varying lengths of time at different degrees of roon temperature and at whatever degree of humidity happened to obtain.

When considering these two methods many advantages of the method of incubation at $37^{\circ} \mathrm{C}$. are evident, including the ease of maintaining this temperature in any laboratory, the evident uniformity of counts so obtained in different places as compared with those obtained by the varying methods of technique, as to temperature, and incubation period, where room temperature is employed, and the quickness with which results are obtained, doing away witl large accumulations of uncounter plates.

Forty-eight hour plates grow1 at $37^{\circ} \mathrm{C}$. give a slightly higher count (11), not enough higlier to inaterially change the report, while the loss by "spreaders"' is increased and the count delayed.

To secure saturation of the atmosphere the incubator slould be made with a shallow depression over the whole bottom surface, which may be kept filled with water, or in default of this a large shallow pan of water may be kept on one of the lower shelves.

Much work will be done on comparison of $37^{\circ} \mathrm{C}$. and " room temperature" during the coming year.

Extract from 1908 report. Summarizing up the work on incubation, we may say that the weight of evidence is against 24 hours incubation at $37^{\circ} \mathrm{C}$. and two day incubation at or around $21^{\circ} \mathrm{C}$., the number of colonies obtained being too small for a fair idea of the number of bacteria in the sample.

Eight day and ten day incubations at $21^{\circ} \mathrm{C}$., while giving a slightly higher average count, have disadvantages, such as delay in reports, accumulation of plates and drying out of media, which render them undesirable for routine work.

The lines of highest efficiency on a working basis would seem to rest on a 48 hour incubation at $37^{\circ} \mathrm{C}$. and a five day incubation at $21^{\circ} \mathrm{C}$.

It would seem advisable to recognize as standard both of these methods of incubation (it being understood that carefully regulated incubators should be used).

Board of Health regulations governing the number of bacteria allowable in milk, sliould state the metlod to be used in exanination and in all reports, papers, etc., on the bacterial count of milk this factor slould be explicitly stated. 


\section{Counting.}

Expression of results. Since minor differences in milk counts are within the working error of the methods and are of no significance in practice, the following scale has been adopted for recording results of market milk examinations :

Counts below 100,000 are distinguished by ten thousands.

Counts between 100,000 and 500,000 are distinguished by fifty thousands.

Counts between 500,000 aud 1,000,000 are distinguished by hundred thousands.

Counts between $1,000,000$ and 2,000,000 are distinguished by two hu11dred thousands.

Counts between 2,000,000 and 5,000,000 are distinguished by five hundreel thousands.

Counts above 5,000,000 are distinguished by millions.

Therefore only the following figures are used in reporting :

\begin{tabular}{|c|c|c|c|c|c|}
\hline Below & 10,000 & Above & 250,000 & Above & $1,400,000$ \\
\hline Above & 10,000 & . & 300,000 & ، & $1,600,000$ \\
\hline " & 20,000 & “ & 350,000 & “" & $1,800,000$ \\
\hline ، & 30,000 & 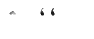 & 400,000 & “، & $2,000,000$ \\
\hline ". & 40,000 & .' & 450,000 & ، & $2,500,000$ \\
\hline . & 50,000 & ." & 500,000 & “" & $3,000,000$ \\
\hline ، & 60,000 & $" ،$ & 600,000 & “" & $3,500,000$ \\
\hline ، & 70,000 & " & 700,000 & “ & $4,000,000$ \\
\hline ." & 80,000 & ، & 800,000 & ." & $4,500,000$ \\
\hline . & 90,000 & ، & 900,000 & ". & $5,000,000$ \\
\hline ." & 100,000 & ، & $1,000,000$ & ' & $6,000,000$ \\
\hline “" & 150,000 & " & $1,200,000$ & etc.. 1 & by millions \\
\hline "، & 200,000 & & & & \\
\hline
\end{tabular}

Counts on "certified" or "inspected" milk shall be expressed as closely as the dilution factor will allow.

The whole number of colonies on the plate shall be counted, the practice of counting a fractional part being resorted to only in case of necessity, such as partial spreading.

Various counting devices have been recommended by different workers. The more simple ones, where the whole plate can be seen at once, are more desirable on account of there being less likelihoor of recounting colonies. Colonies too snuall to be seen with the naked eye or with slight magnification shall not be consiclered in the count. 
BIBl, IOgRAPHY OF COMMITTEE REPORT.

1. Transactions A. P. H. A., Vol. XXX, Part II.

2. Comparison of Media.

a. Heinemann, Appendix A.*

b. Prescott, Appendix B.*

c. Prescott, Teclinology Quarterly, Vol. XVIII, No. 3, page 252.

d. Report Boston Board of Health, 1906, page 74.

3. Fuller and Copeland, Report Massachusetts State Board of Health, 1906, page 585. Muir and Ritclie, 1903, page 37.

4. Slack, Appendix C.*

5. Hill and Films, Report of Brooklyn Water Supply, 1897.

6. Hill, the Mathematics of the Bacterial Plate Count; Paper read before Laboratory Section A. P. H. A., Sept. 30, 1907.

7. Slack, Appendix D.*

8. Slack, Appendix E."

9. Report Boston Board of Health, 1906, page 76 .

10. Stokes, Appendix F.*

11. Hill and Slack, American Journal of Public Hygiene, November, 1904, page 237 .

12. Gorliam, Laboratory Course in Bacteriology, page 54.

13. Method used by H. W. Hill, Minnesota State Board of Health Laboratory.

14. Heineman11, Appendix G**

15. Campbell, Appendix H.*

16. Hill, Journal of Merlical Research, Vol. XIII, No. 1 (New Series, Vol. VIII, No. 1), pages 93-96, December, 1904.

17. Gage, Appendix I.*

Significance of results. In the interpretation of the results of the numerical determination of bacteria in milk, it must be constantly borne in mind that the results indicate only conditions at the moment the sample was taken. We are not dealing with the quantitative estimate of a milk constituent like fat, which is present in the same proportion in a given sample at all times. It must be remembered that a bacterial count is a measure of the progress of multiplication of a complex mixture of micro-organisms, controlled by an equally complex series of factors. The results at any given time depend in part upon initial numbers, species, characteristics of the milk, its age, the temperature at which it has been kept,

\footnotetext{
* Reference to Appendix of Committee report, to be found in the American Journal of Public Hygiene, N. S. Vol. III, 1901, No. 5, pp. 354 to 364.
} 
and the method of making the determination. Wrong conclusions will be reached, if emphasis is laid upon mere nu1ubers without a consideration of the other factors.

A numerical determination taken by itself without full consideration of all the factors involved has no value. Persons not familiar with the circumstances are apt to attempt to make comparisons when such are inadmissible. The results of the work of two laboratories cannot be compared, unless there has been uniformity in every detail that would affect results. Every bacteriologist doing much milk work has had embarrassing experiences along this line. The man who has had the longest experience with numerical determinations of bacteria in milk in connection with milk commission work believes that no good end is served by stating results publicly in numerical terms, and acts in accordance therewith. In any event, the publication of numerical results should be restricted to a small circle of persons who appreciate their significance.

The bacterial count is undoubtedly the instrument by which the effectiveness of good dairy methods is measured, and has been a prominent factor in the development of those methods. It reveals facts regarding the operation of high grade dairies that 110 inspection could disclose. A count of certified milk is better evidence of the observance of certain features of cleanliness in handling the milk than a visit to the dairy.

The value of the bacterial count in locating contamination is recognized by careful dairymen. Some large distributing firms use the method to good advantage in controlling the producing dairies. Postal card reports sent from time to time convince the dairyman that his product is under scrutiny and stimulate him to greater efforts.

Microscopic estimate of bacteria. Slack has observed that, in connection with his method for the study of milk sediments, the number of bacteria may also be roughly estimated. By a long series of comparative tests, it has been found possible to tell from the number of bacteria in the smear whether or not plate cultures would show above or below 500,000 colonies per cc. An error of less than 1\% was made in this regard. Slack uses the test to eliminate those samples of milk that are well 
within the limit, and thus saves the trouble of plating them.

The committee of the A. P. H. A. in its 1908 report (4) makes the following comment:

"Several laboratories are now making this examination as a routine procedure. One worker (Conn), who has done considerable experimentation along this line during the past year sums up his results in attempts to actually approximate plate counts as follows :

"' The method seens to be fairly satisfactory for milk, the bacterial content of which is not too low or too high. When the numbers are down below ten thousand the method seems to be quite inaccurate, and when the numbers run up into the millions I find also the numbers are not very reliable. Within the limits of from thirty thousand to three hundred thousand, however, the method seems to be fairly good. I have, however, had the experience of occasionally finding samples of $111 \mathrm{k}$ * which, when tested by direct microscopic methods, gave results very different from those by the plate method. My general feeling is that a direct microscopic method might give an idea as to whether the sample is very good or very barl, but would not replace the plate method of examination in determining actual numbers and would be of no use for the examination of samples of milk whose number of bacteria is quite low.'

“Another (Campbel1), who has done nuch work with this method, finds it chiefly useful as a prelininary test, not. plating samples which are shown by the microscope to contain less bacteria than the city regulation permits, in those samples which are plated it serves as a guide for the proper dilutions. He finds it possible with this examination to correctly state in nearly every instance when a milk contains less than 50,000 bacteria to a cubic centimeter, or when it contains over a million bacteria to the cc. On actual estimates within 50,000 of the plate count his average is $66 \%$ correct on counts between 50,000 and 500,000 and 50\% correct on counts between 500,000 and 1,000,000."

The subject of the microscopic examination of milk for leucocytes and streptococci is discussed in Chap. VII.

Tests for B. coli. Methods for the examination of milk for $B$. coli are in the process of evolution. The question of the accuracy and significance of some of these tests has received some attention by the committee of the A. P. H. A. in its 1908 report. The methods have hardly been tested out sufficiently to warrant recommendation for general use.

Examinations for typhoid fever and diphtheria bacilli. In connection with the investigation of milk-borne epidemics of typhoid fever and diphtheria, the desire is very frequently 
expressed for an examination of the milk with respect to the presence or absence of the germs of these diseases. The technical difficulties at present surrounding such work are too great to render it worth undertaking as a matter of routine. Then too it is very likely the germs may not be present at the time milk is under suspicion, which may be long after the pollution of the milk occurred. The presence of diphtheria bacilli in milk has been demonstrated by the inoculation of guineapigs with centrifugal sediment and the production of diphtheria. The relation of milk to these diseases as demonstrated by other means is discussed in Chap. III.

Tubercle bacilli. The examination of nilk for tubercle bacilli is not recommended as a profitable line for routine work. Owing to the fact that tubercle bacilli appear in milk intermittently, a negative result is of no significance in showing the usual quality of the milk in this regard. Nevertheless, occasions arise when the interest in the result warrants the trouble taken to secure the information as to the presence of the tubercle bacilli.

The work described below calls for the use of a large centrifugal machine instead of the ordinary machine used in urine analysis, but the latter may be employed with the disadvantage of using the smaller amount of milk. The technic varies soinewhat with different workers, but that of Anderson (1) is given here and is also recommended by the A. P. H. A. committee.

To $50 \mathrm{cc}$. of well-mixed sample in a sterile centrifuge flask, add $100 \mathrm{cc}$. of sterile distilled water. Centrifugalize at 2,000 revolutions for one hour. Five cc. of the sediment is inoculated into each of at least two guinea-pigs subcutaneously in the abdomen, using a different syringe for each pig. An equal number of control pigs are kept with those inoculated, as a control on health of stock, environment, etc.

Examine for enlarged glands after four weeks and separate those showing evidence of tuberculosis. Pigs are apt to die early from acute infections resulting from bacteria in the milk other than tubercle bacilli. Those alive at two months are given $2 \mathrm{cc}$. of crude tuberculin, which kills badly tubercular 
pigs and sickens those with slight lesions. Others, presumably non-tubercular, are chloroformed. At antopsy, all organs showing deviations from the normal are examined for tuberculosis by smears, cultures and sections. * Care must be taken to differentiate tuberculosis from the lesions of Bacillus pseudo tuberculosis. This organism causes peritonitis with adhesions and nodules in organs like the liver or spleen, which show a tendency to central necrosis. In section these nodules are seen to consist of lymphoid elements, very few epithelioid and multinuclear cells. The giant cells typical of tuberculosis do not occur. Cultures grow more rapidly than those of $B$. tuberculosis.

The older method of direct microscopic examination of milk sediments for tubercle bacilli is quite inadmissible, and all conclusions based upon it have to be discarded. Other organisms having the staining peculiarities of $B$. tuberculosis (acid-fast) are frequently found in dairy products. Johne's disease, affecting the intestines of cattle, is caused by an organism similar in morphology to B. tuberculosis.

Determination of streptococci. Streptococci may be recognized on the plates made in connection with the standard method for numerical determination. The colony is small, consisting of a slightly elevated center surrounded by a thin spreading border. Their significance in a quantitative sense is discussed in Chap. VII.

Qualitative determinations. The examination of milk by methods permitting the determination of the percentage of various groups of organisms has been quite extensively used in the study of dairy problems, and has yielded valuable information (2). Certain characteristics of growth on plates, such as formation of acid, character of colony, and liquefaction of gelatin, have been made the basis for the identification of groups of organisms for the' study of their growth under various conditions. The relative proportion in which certain

* Dear tubercle bacilli, killed for instance by pasteurization, may lead to the formation of small tubercles, with no tenclency to further multiplication. Sone workers consider it well to inoculate a second pig from these lesions, to settle doubt as to their nature. 
groups of organisms are present in milk is of importance. It is doubtful, however, if the necessity for this information would warrant the use of the method in the ordinary control work in connection with municipal milk supplies. Qualitative exaninations are of decided advantage in the examination of pasteurized milk.

\section{REFERFNCES.}

Notr.-The reference numbers in parentleses occurring in the A. P. H. A. report on pages 141 to 149 refer to the bibliograply accompanying that report on page 150 .

1. AndFirson. The frequency of tubercle bacilli in the market milk of Washington, D. C. Bul. No. 11, Hyg. Lab., L. S. Pub. Health and Mar. Hosp. Serz, Washington, D. C., 1908, p. 163.

2. CONN and HistFn. Qualitative analysis of bacteria in market milk. Fifteenth Ann. Rept. Storrs Agr. Exp. Sta., Storrs, Conn., 1903, p. 63.

3. Preliminary Statement by the Committee on Standard Methods of Bacterial Milk Analysis to the Laboratory Section of the Anerican Public Health Association. Amer. Jour. Pub. Hyg., Vol. XVII, 1907, No. 4, N. S. Vol. III, No. 5, p. 331.

4. Manuscript report of the same conminttee for 1908. 


\section{CERTIFIED MILK.}

Milk commissions. The medical milk commission movement is the outgrowth of the efforts of one physician to secure clean milk. Dr. Henry L. Coit of Newark, N. J., recogniized the inadequacy of state and municipal methods of dealing with the milk problem. He and his associates, in 1893, organized a professional organization known as the Medical Milk Commission of Essex County, New Jersey. They drew up regulations covering the methods of producing clean milk, quality of the product, etc. One dairyman, Mr. Stephen Francisco, agreed to conform to the regulations; in default of which he was to forfeit the support of the commission in guaranteeing his product to the profession.

The object and scope of the work of the commission were defined as follows (8):

"'The objects of this commission are to establish correct clinical standards of purity for cows' milk; to become responsible for a periodical inspection of the dairies under its patronage: provide for chemical and bacteriological examinations of the product, and the frequent scrutiny of the stock by competent veterinarians; to promote only professional and public interests.

"The following are three general requirements or standards for the milk: (1) An absence of large numbers of micro-organisms, and the entire freedom of the milk from pathogenic varieties; (2) unvarying resistance to early fermentative changes in the milk, so that it may be kept under ordinary conditions without extraordinary care; (3) a constant nutritive value of known chemical composition, and a uniform relation between the percentage of fats, proteids, and carbolydrates."

Dr. Coit suggested the use of the phrase " certified milk" to designate the product turned out under the approval of the commission. Mr. Francisco, in order to protect the word " certified" from illegitimate use by trade competitors, regis- 
tered it in the Patent Office. The original certified dairy has prospered and to-day is one of the largest sanitary dairies in the comntry. The idea of milk certification spread slowly at first, but now about forty milk commissions are scattered over the country $(1,2,7,8,12)$.

Association of milk commissions. For purposes of mutual benefit, the various commissions have formed an association under the name of The American Association of Medical Milk Commissions. The original purposes of the association are best defined by Article II of its constitution (1):

"The purpose of this Association sliall be to federate and bring into one compact association the Medical Milk Comnissions of the United States; to exchange views and to adopt uniform methods of procedure in the work of the Medical Milk Commission; to fix chenical and bacteriologic standards; to determine the scope of medical and veterinary inspections, and to foster and encourage the establishment of Medical Milk Commissions in other cities.',

During the two years of the existence of the association, it has abundantly fulfilled expectations.

Source of authority. A milk commission should derive its authority from a regularly constituted medical society by whom it is appointed and to whom it is responsible. The majority of the membership should be physicians, and the commission should be a strictly medical organization with professional objects for the public good. It is quite a general practice to appoint a minority of lay members on commissions in order to afford representation for civic bodies prominently identified with the clean milk movement. Exceptions as to the appointing body have occurred in the case of milk commissions emanating from civic bodies. For instance, the pioneer milk commission in California was established by a woman's club. It is well, however, to adhere to a county medical society as a source of authority in order to preserve a sharp distinction between the legitimate and the illegitimate.

Field of milk commission activities. A milk commission is not designed necessarily to invade the field of ordinary municipal milk inspection, although some schemes for such milk inspection recognize milk commission work. The commission 
sets the necessary high standard for the production of irreproachable milk and agrees to certify the milk of as many dairymen as desire to follow its rules. Only in the larger cities should a commission expect to enlist a number of dairymen. Many commissions have only one dairyman, although it is rather embarassing to recommend the milk of but one dealer.

In many cases, a milk commission cannot demand that a dairyman shall sell only certified milk. The consumers of this grade of milk are few and widely scattered. Under such conditions, the expense of delivery of certified milk alone would be prohibitive. A commission can hardly concern itself with other business relations of the dealers further than to refuse certification to a dealer known to sell adulterated milk.

The milk commission reports its findings to the appointing body, whence announcement of its conclusions is made to the profession. Announcement is best made by means of a postal card mailed from month to month.

Agreement with dairymen. The first commission entered into an elaborate contract with the dairyman, in which every detail was carefully defined. In other cases, it has been found sufficient to furnish the dairyman a list of the requirements of the commission with the information that habitual non-compliance will result in the withdrawal of certification. The various commissions do not have uniform requirements, but this may come in time. The purpose to be attained seems to be a definition of minimum requirements, in order not to deter the various commissions from trying improvements.

Sanitary requirements for dairymen. These vary slightly with different commissions. The following ones, drawn up by Professor R. A. Pearson, an acknowledged expert on the matter, were adopted at the 1907 meeting of the American Association of Medical Milk Commissions, and may well be followed :

\section{Jocation AND CHARACTER OF LANDS.}

"Certified", milk shall be produced only on good farming land, which, togetler with all equipment and methods, is approved by the Commission. 
Pastures or parlilocks to which cows have access shall be: (1) Free from marsli or stagnant pool; (2) Crosserl by no strean which night easily become rlangerously contaminated; (3) At sufficient distance from offensive conclitions to suffer no bad effect from then.

\section{OCATION, CONSTRUCTION, Iaghting, AND VeNTILATION OF STABl,AS AND OTHLR BUILDINGS.}

Buildings in which " certified" milk is produced or handled shall be located where good clrainage can be secured and at sufficient distance from other buildings, dusty roads, cultivated and dusty fields and other possible sources of contamination, to avoid excessive dirt, dust, or orlors froml such places.

The stables shall be constructed so as to favor the confort of the cows and the efficiency of labor. The floor shall be of cement or an equally durable and non-absorbent material, and sloperl to provirle drainage. Stall floors may be constructed of sound plank well laid on cement.

The insirle surface of the walls and all interior construction sliall be smooth, with tight joints, and capable of shedling water. The ceiling shall be of snooth material and dust tight. All horizontal and slanting surfaces which might harbor dust sliall be avoirled as far as possible.

The stable shall be as well lighterl as the average house, and shall have an average of at least four square feet of window glass for each animal, with as much sunlight as possible, and the light evenly distributed.

The ventilation shall be so efficient that one will not notice a stale, disagreeable, or strong odlor on entering the building.

\section{DRAINAGE.}

Drainage from buildings shall be carried under ground to a point at least one hundred feet from any building used for prodncing or handling milk, and so far away that odors from the drain openings can not find entrance to the buildings.

\section{WATER SUPPLY.}

There shall be an abundance of pure water from an approved city or town supply, or from a deep well or deep spring, thorouglily protected against the entrance of surface water and located not less than one hun' dred feet from stable, barnyard, privy, or other possible sources of contamination.

No other water except that from approved reservoirs or filters shall be used for cooling milk, cleaning utensils, or otherwise in the dairy house. The cows may be permitted to drink from a running stream of clear water.

Examination of water. The water shall be examined by the bacteriologist and chemist at least once each winter and once each summer, 
and nay be rejected whenever the purity is suspecterl. Samples of water for analysis shall be furnisherd as often as requesterl.

\section{RHMOVAI, OF WASTI: IFROM S'TABI,}

All waste sliall be renover and the stable thoroughly cleaned throughout at least once daily. When cows are kept in the stable continuously, the manure shall be removed from the stalls at least twice rlaily.

\section{SIRROUNINGS OF BLHIDINGS.}

Surroundings of all buildings shall be kept clean and in good order. The accunulation of dirt, rubbish, manure, or decayed matter shall not be permitted. The stable yard shall be well drained.

S'rock.

The herd shall include no aninal that is known to be discased or that seens to slow evidence of acute, chronic, local, or otlier disease, unless permitted by the veterinarian.

Test for tubcrculosis. Tuberculin shall be user in examination for tuberculosis whenever requirerl by the rules governing veterinaty inspection.

Additions to herd. Animals proposed to be added to the herd shall be kept in a separate quarantine building, at least two hundrerl feet from the stable, and their milk shall not be userl until approved by the veterinarian, after a plysical exanination and tuberculin test.

Exclusion from herd. Any animal showing evidence of general illhealth and any that is off-feed shall be at once removed from the stable and its milk withlield.

So far as possible, the cows shall be grouped or milked in groups, so that the milk collected in any short period shall show about the same composition as the average for the herd.

Housing. The cows shall be kept in confortable and healthful quarters and not unnecessarily exposed to inclement weather.

Foods. All food stuffs shall be kept in an apartment separate from the cows and used only after milking, and slall not be brought into the stable except just before being fed.

- Only those feeds shall be used which consist of fresli, palatable, or nutritious materials, suclı as are known will not injure the health of the cows or unfavorably affect the taste or cliaracter of the $111 \mathrm{ilk}$.

A well-balanced ration shall be used, and changes of feed sliall be made slowly.

Water. Cows shall be given fresh water at least twice daily.

Calving-Exclusion from the herd. Cows shall be removed from the stable in which the herd is kept at least twenty-one days before due to calve, and not returned until seven days after calving. 
E.tercise. Cows shall be permitter to exercise.

They shall be cleaned, milked, and fed regularly, and always treated kinclly.

Jong hair on the udder and surrounding parts shall be clipper.

PREPARATION OF THE COW FOR MILKING.

Grooming. At least half an hour before milking, the cows shall be thorouglily cleaned, and compelled to remain standing until milked.

Final cleansing. Not more than ten minutes before each milking, the udders and surrounding parts shall be thoroughly cleaned by the use of moist clean cloths.

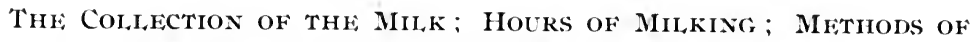
MILKING: THE USE OF THE MILKING MACHINE.

Fore-milk. The first three or four streams from each teat shall be drawn into a separate vessel and discarded.

Milking shall be done in a quiet, clean, and thorough manner, and at regular hours; as nearly as possible, at twelve-hour intervals.

No person not employed in the stable shall be allowed there during nilking.

The milking machine may be used subject to the approval of the veterinarian and bacteriologist.

Milk to be discarded. If the milk appears bloody, stringy, or otherwise unnatural, or if dirt gets into it, it shall be discarded and the pail washed and sterilized before it is again used.

lilking cows excluded from herd. Cows separated from the herd shall be milked after the herd is milked or by other milkers than those employed with the herd.

Cooling. Immediately after each cow is milked, the milk shall be taken to the milk room for cooling and bottling.

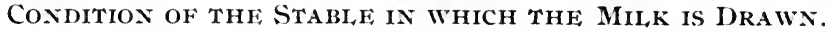

The stable shall be kept scrupulously clean. Interior walls shall be light in color. If whitewash is used, a fresh coat shall be applied at least three times a year, and oftener if necessary, to keep the walls clean and white. Mold spots shall not be permitted.

Tools, when not in use, shall not be exposed in the stable.

The stable shall be thoroughly cleaned at least once daily. Neither this nor other work which would stir up dust or odors shall be done within thirty minutes before milking time.

While cows are being cleaned, the stable sliall be thoroughly ventilated, and the floor may be sprinkled to reduce the dust.

At least once every two months, the mangers shall be scrubbed with a brush and soap, lye, or washing powder. 
Calves, dry cows, horses, or other aninuals, or chickens, shall not be allowed in the stable witl milking cows, nor in any adjoining apartment.

No dusty or moldy hay or straw, bedding from loorse stalls, or otler unclean material shall be used for bedding cows.

Preparation of THE MIhKERS ; 'THEIR CheANing; THEIR Drliss.

A special room, conveniently located, shall be provided for the milkers to wash in before and during milking.

Employees shall be clean in habits and appearance.

Contagious diseases. No person having an inflamed throat, or otherwise out of health, shall be admitted to stable or dairy room.

The existence of smallpox, typhoid fever, diphtheria, scarlet ferer, measles, or other contagious disease on or in the vicinity of the dairy shall be immediately reported to the Commission ly telephone or telegrapl, and the sale of milk shall be subject to the direction of the medical inspector.

No person connected with the dairy shall enter a house where there is, or has been, a contagious disease, until same las been disinfected, and no person having entered such a house shall enter upon the dairy premises.

While, engaged about the dairy or in handling the milk, employees shall not use tobacco or intoxicating liquors.

Hands of Milkers.-Washing. Before milking, the milker's hands shall be thoroughly cleaned by the use of soap and a brush, and then rinsed in clean water. He sliall be careful not to touch anything but the clean top of a milking stool, the milking pail, and the cow's teats. The hands shall be kept dry when milking.

Milkers shall wear outer garments which are washed at least twice each week, and, when not in use, kept, not in a dwelling, but in a clean, ventilated place where dust does-not have access and provided especially for this purpose.

Shape, Preparation, and Condition of Vessels for Receiving THE MILK.

The milk shall come in contact with no vessel or apparatus which is not clean and practically sterile.

The opening of the milking pail shall not be larger than a circle seven inches in diameter. A visor or hood to further reduce the opening is recommended.

The Straining, Cooling, and BotTting of the Milk:

Promptly after milk is drawn, it shall be strained through a fine wire gauze and a layer of absorbent cotton, protected on each side by a piece of cheese cloth, or an equally good.strainer. 
It shall be cooled at once to $50^{\circ} \mathrm{F}$. or lower, and maintained below $50^{\circ} \mathrm{F}$. until delivery. No ice shall be put into the milk.

The milk shall be bottlerl promptly, and may be bottled before cooling, providing this systenl assures cooling within fifteen ninutes from the cow.

Milk shall be stored only in the milk room.

Water used for cooling or storage purposes shall be kept fresh and free from odor.

No preservative or other substance shall be adderl to the milk for any purpose, and no part of the milk shall be removed; but the arldition or subtraction of cream may be practiced when specially permitted by the Commission for the purpose of producing milk of guaranteed standard, provided this does not conflict with milk laws and ordinances.

\section{LOCATION ANI CONITION OH COOLANG ANI BOTTLING ROON.}

The bottling room shall be within easy access of the stable, but so placed that it cannot easily be reached by dust or odors from the stable or yarl or other source.

It shall be used for 110 other purpose than to provide a place for handling the milk, storing clean milk utensils, and holding fresh milk previous to its removal from the dairy.

This room shall be entered only by persons having business therein, and wearing clean outer garments.

It sliall be kept scrupulously clean.

Utensils shall be promptly removed after use and cleaned in another room.

The milk roon sliall be well lighted and screened, and drained through well-trapped pipes.

\section{PACKAgks fOR THE TRANSFer OF MiLK.}

A flint glass bottle free from permanently attached parts shall be used for the delivery of milk.

\section{Cifeansing of Mirk Containers.}

All milk containers and utensils shall be thoroughly cleaned by hot water and salsoda or other equally pure agent, rinsed until the cleaning water is thoroughly removed, then exposed to live steam or boiling water at least twenty minutes, then held until used where dust and other contaminating material will not have access.

\section{SFALS.}

Milk bottles shall be sealed as soon as possible after filling, and they shall not be opened before delivery. A satisfactory seal consists of melted paraffine carefully poured over the cap and impressed with date.

In addition to the stopper which confines the milk, the lip of the bottle sliall be protected by tin foil caps or heary parclinent paper circles. 
HOW ARE THE CAPS FOR MIIK BOTTI,ES MARKED?

Caps to close milk bottles shall be markerl to slow the claimed quality of the milk (or cream). On the caps or elsewhere, but accompanying eacli package, there shall be stated the name of producer, name of dealer (if different), name of Commission, guarantee of Commission, and expiring date of same.

TRANSPORTÁTION.

At no time between the cooling of the milk and its delivery shall its temperature be allowed to exceed $50^{\circ} \mathrm{F}$.

Except when the outdoor temperature is below freezing, ice sliall be placed in the bottle cases.

Milk shall reach the consumer within thirty hours after production.

Experts employed by milk commissions. In the work of dairy inspection and examination of the product, it is usual to employ four experts, a veterinariain, a bacteriologist, a chemist and a medical examiner. The compensation for their services, always paid by the dairyman, is collected in various ways. Some commissions sell bottle caps or other distinguishing devices at a price that covers the whole expense of examination, about five dollars per thousand. Others have a graduated fee roughly proportional to the output of the dairy. In other cases the dairyman pays a specific fee for each examination. Very frequently public laboratories are able to make chemical or bacteriological examinations gratis or for nominal fees.

l'eterinary inspection. The duty of the veterinarian is to determine the general health of the animals, to observe the sanitary conditions and to scrutinize the technic of milk handling. In general, his duty is to determine if the conditions of the agreement of the dairyman with the commission are being observed. His criticisms and suggestions must maintain that degree of alertness on the part of the foreman of milkers and other employees that shall minimize the possibility of contamination of the milk.

The control of bovine tuberculosis is a task that demands the utmost vigilance. Without care in regard to this disease, the pretensions of a certified dairy are fraudulent. When not rigorously dealt with, it constitutes the greatest menace to the financial success of a certified dairy. Tuberculin tests 
a year apart, with careless supervision of additions to the herd, are useless in a herd that was badly infected at the beginning, for tuberculosis will keep pace with lax efforts directed against it. It is not sufficient to test merely the cows that happen to be in milk at the time of the test. Every dry cow should be included. In an infected herd, a test once in six months is regarded as necessary, followed each time by thorough disinfection of the stable. The control of tuberculosis cannot be accomplished by one test carried out in a perfunctory manner, but the struggle must extend over years.

Additions to the herd must be tested with tuberculin, but there is always danger that an animal, though not reacting, may introduce the disease. On this account it is far better to subject each animal added to the herd to a three months' quarantine with a tuberculin test at the beginning and end of this period. During the period the milk may be used.

The details concerning the tuberculin test and management of the disease are given in Chap. IV.

Bacteriological examinations. The numerical determination of the bacteria in milk is made every week and constitutes a useful check upon the methods employed in producing and handling the milk. A low count indicates that cleanliness has been observed in the care of the utensils and in milking, and that the product has been properly refrigerated. The bacterial count is made of the milk when about the age that it ordinarily is when it reaches the consumer. Care should be taken that the sample be kept properly refrigerated until the examination is made. The samples should be taken from the dairyman unexpectedly as regards time and place. Thus it would be impossible for him to submit extra good samples with fraudulent intent. The numerical determination of the bacteria in milk is a good safeguard against the fraudulent sale of ordinary dirty milk under the guise of certified milk. 'There is a very wide difference in the results that are obtained by examining the samples of these two classes of milk and thus fraud may be detected.

The grade of milk designated "certified" should never contain more than 10,000 bacteria per cc. If there is a second 
grade known as "Inspected " milk, it should not contain more than 100,000 bacteria per cc. in summer and 60,000 bacteria per cc. in winter. It is unfortunate and confusing to have milk commissions recognize two grades of milk. The technic of the bacteriological examination of the milk is described in chap. VIII.

Reporting on samples and keeping records of results is facilitated by the use of a 3 by 5 -inch card printed for the reception of data as follows :

REPORT OF NUMERICAL DETERMINATION OF BACTERIA IN MILK .

Dairy. Reported

Collecterl at. Date Hour

Milk drawn at. (A. M.) (P. Ir.). Plated at (A. M.) (P. M.) Max. possible age hrs. Temperature when plated C. Colonies per cc. Conclition of package.

Chemical examinations. Chemical examinations are generally made monthly. A committee of the Annerican Association of Medical Milk Commissions has made a report on chemical standards, which is very briefly abstracted here (3). Milk rated at $4 \%$ fat should range from $3.5 \%$ to $4.5 \%$, and $5 \%$ milk from $4.5 \%$ to $5.5 \%$. The Babcock test is recommended, but in case of condennation for low fat control by the ether-extraction method is desirable.

Protein estimations are not recommended as a routine.

It is suggested that regular tests be made for formaldehyde with the sulphuric acid-ferric chloride test, and if the test is positive, that the specimen be distilled and the distillate tested. Borax and boric acid may be looked for by the turmeric test. Tests for salicylic acid, benzoic acid and benzoates may be made four times a year at unexpected intervals.

It is recommended that tests for heated milk be regularly carried out as a check against the use of undesirable high pasteurization temperatures, which alone can be detected by test.

Acidity tests of certified milk are of little importance. L,ikewise, a specific gravity standard need not be set for certified 
milk. Routine tests for specific gravity should be carried out as a check against gross adulterations.

lledical inspection. The health of employees and of their families offers an important field for the exercise of precautionary measures. In some cases, a weekly postal card report concerning health conditions is required of the dairy superintendent. The use of diphtheria swab examinations to detect carriers of diphtheria infection about a dairy has not been adopted, but might well be seriously considered. The possibility that " carriers" of both typhoid fever and diphtheria bacilli may work about a dairy without recognition by an ordinary examination is a troublesome feature.

The certified milk package. The fundamental idea in the delivery of certified milk is to have the milk bottles sealed at the dairy and marked with a derice indicating the approval of the commission. The Brooklyn commission sells the dairymen bottle caps bearing a certification label, and illegitimate use of them may be prevented by taking care that the consumption of caps does not exceed the output of the certified herd. After the caps are affixed in the bottles, a layer of paraffin is placed over the cap and before it cools an impression is made with a rubber stamp, marking the date upon which the milk is to be sold and used. The stamps are the property of the commission, and contain certain private marks by which the experts of the commission may recognize the impression. The stamps are assigned to different dairymen from time to time. Other commissions issue slips bearing a statement concerning certification, which are issued to the dairymen and placed over the paper cap. Such a slip bears information as follows:

\section{ST. LOUIS PURE MILK COMMISSION. \\ Mil, Commission Certificate.}

Date

Milk or crean from the dairy of. and the lairy itself have been recently examined by the experts of the Commission and found to be up to the required standards of excellence. Another exanination will be nuade within a month, and, if satisfactory, new labels for the bottles will be issued rlated

(Notice tle date.) 
The top and lip of the bottle are protected by an additional cap extending down orer the neck. This may be of tinfoil with ornamental lettering. Another device consists of a 6-inch circle or square of parchment paper crumpled around the neck and held in place by a rubber band. The paper may bear a printed label.

Certified milk may be delivered in bulk to institutions in cans the covers of which are fastened with a lead seal distinctive of the certification of the commission.

Amount of certified milk produced. Certified milk at present constitutes a very small percentage of the general milk supply. Dr. Coit, in his presidential address before the American Association of Medical Milk Commissions, held in Chicago, in 1908. made the following comment :

"In New York City, the 10,000 quarts of certified milk is only one-half of $1 \%$ of the $1,800,000$ quarts consumed daily, and if every quart of certified $1111 \mathrm{k}$ went to a baby, which it does not, it would be less than $5 \%$ of all the babies in New York City, which is 205,000."

Certified milk has been before the public in New York since 1896, twelve years. The small amount consumed represents the small proportion of people in the country now who realize the necessity for good milk and are able to pay for it. The figures offer subject for thought in connection with the problem of educating the public in the matter of paying twelve to twenty cents a quart for good milk.

Certified milk is producing a good effect in the various communities where it is known, out of all proportion to the amount of such milk produced. It has been a potent factor in arousing the present wave of interest in clean $111 \mathrm{ll}$ which is sweeping over the country but is not a response to the demand for pure milk for the masses.

Fraudulent certified milk. There was an instance in Louisville, $\mathrm{Ky}$., in which a dealer employed two physicians and a veterinarian on salaries and sold milk under their "certification." In another case, milk was sold as "certified milk", on the basis of a falsified tuberculin test by two disreputable veterinarians. The difficulty has been met in New York State by legislative action as follows : 
"No person shall sell, exchange or offer or expose for sale, or excliange as and for 'certified' milk, any milk which does not conform to the regulations prescribed by, and bear the certification of, a Milk Connunission appointed by a County Medical Society organized under and chartered by the Medical Society of the State of New York and which has not been pronounced by such authority to be free from antiseptics, added preservatives, and pathogenic bacteria or bacteria in excessive numbers. All milk sold as 'certified' 111ilk shall be conspicuously marked with the name of the Conn111ission certifying it."

In Kentucky a conviction has been obtained in the Circuit Court, under the state pure food law, on the ground that the fraudulent certified milk had been so advertised as to deceive and defraud the public. It was established that the term "certified milk" had come to have a distinctive meaning. In California, the institution of similar proceedings under the pure food and drugs act of that state induced a dairyman to stop the illegitinate use of the phrase. Tuley (13) has discussed this problem thoroughly.

Infringenent in the matter of the use of the term "certified milk" cannot do very much harm, for it is a simple matter for a medical milk commission to notify the profession and the public of the fraudulent nature of the claims.

Maintenance of standard. That the milk produced in a number of certified dairies is really what it is claimed to be by the milk commissions controlling those dairies has been shown in an investigation conducted by the Dairy Division of the U. S. Department of Agriculture.

Sixteen dairies were visited and scored by a representative of the department. The average score was 93.4 on a scale of 100 (perfection). The average score of several details was as follows : Cows, 99.5 ; stable, 87.2 ; milk house, 94.5 ; milking, 94.0 ; handling of milk, 93.0. It should be noted that the high score of the cows was based largely upon credit given for the tuberculin test required by all commissions, but which was not made by the Department of Agriculture.

Twelve samples of certified milk (four days old) were scored, with an average of 86.0. The bacterial count varied from 280 to 19,000 per cc. (8). 
Milk dispensaries. In France, the decreasing birth rate first stimulated an interest in agencies for decreasing the death rate of infants. One form of institution called "consultation de nourrisons" is attached to maternity hospitals. Children born in the hospital are kept under medical supervision for two years. They are brought to the hospital once a week, weighed, and medical advice is given the mother. A slightly different sort of institution, goutte de lait (milk dispensary), furnishes milk to the poor in general.

In the work of milk dispensaries the aim is to decrease infant mortality among the poor by remedying methods of care and feeding. Breast feeding is urged, but when this is impossible, a pure supply of milk is prorided. When the circumstances demand, the milk is modified to meet the requirements of the individual infant. Instruction in the proper hygienic care of infants is recognized as quite as important as pure food. This is accomplished most effectively by oral instruction, supplemented by educational pamphlets.

Milk dispensaries are maintained in about twenty cities in the United States. In ten of these, the milk is pasteurized at various temperatures. In six cases certified milk is used and in the others milk from good sources. In general the milk dispensaries are maintained during the summer only, but in some cases they are open during the whole year. Milk dispensaries are maintained as charities. Nathan Straus of New York is particularly active in this form of philanthrophy. Out of the twenty cities in which there are milk depots, only four of them are maintained at the expense and under the supervision of the health department.

There are so many factors involved that it is impossible to place a valuation upon the influence of the clean milk alone, even though the work of milk dispensaries is an important factor in reducing infant mortality $(9,10)$.

Rochester, N.Y., milk dispensaries. Dr. Goler, the Health Officer of Rochester, N. Y., has established milk depots under the control of the health department. A contract is made for the product of a dairy during two months in the sunimer. A temporary laboratory is established at the farm and em- 


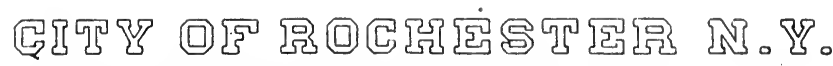
Averaqe. Deaths Unde, 5 Years of Qqe. in Month: Frior to and after The Establishment of Municipal Milk Stations

- SYear Ghart -

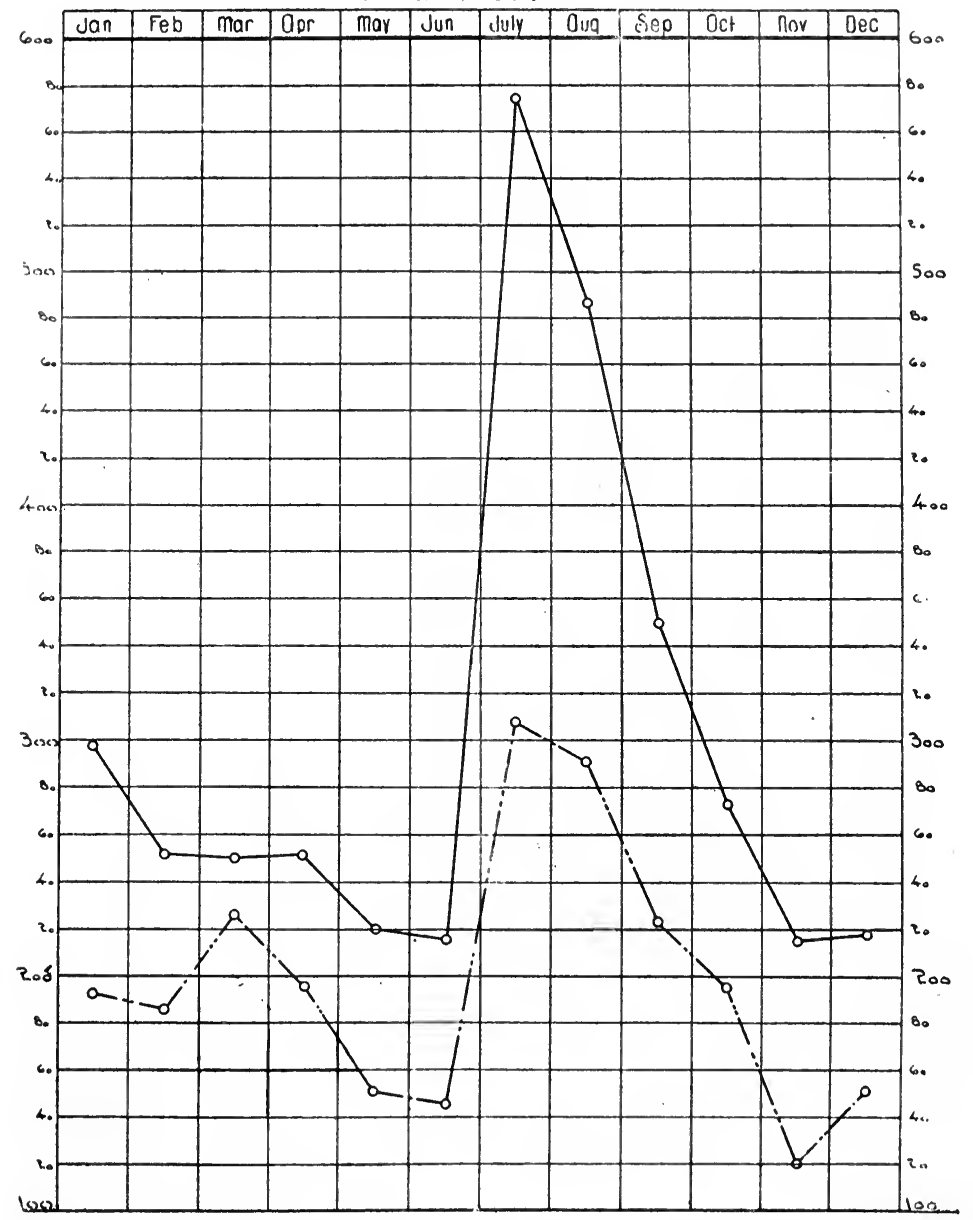

1̈ig. 17. Chart showing relation of municupal milk stations to infant mortality (6). 
ployees of the department supervise the production of the milk, and take charge of it immediately after drawing. The various modifications are made, and the product is shipped in the nursing bottles to the various city dispensing stations. There are four of these stations, each in charge of a trained nurse. The instruction in the care of infants is facilitated by panphlets printed in English, German, Italian and Yiddish.

Fig. 17 by Goler (6) shows the beneficial effects resulting from the establishment of milk stations. The work is accomplished for a season of two months at an expense of about one thousand dollars a year. The system of control of the production of the milk makes it possible to use raw milk $(5,6)$.

The practicability of municipal control of milk stations has been demonstrated, and there is every reason for the adoption of this line of work by other municipalities.

\section{REFERENCES.}

1. American Association of Menical, Milk Commissions. Proceedings of the first annual session. Published by the Secretary, Dr. Otto P. Geier, 124 Garfield Place, Cincinnati, Ohio, 1907.

2. Cor'T. A brief history of the development of the pure milk movement in the United States. Paper read at the Congrès Internationale des Gouttes de Lait, Brussels, 1907.

2 a. CorT. Clean milk in its economic and medical relations with special reference to certified milk. Kentucky State Medical Journal, May, 1908.

3. EDSali, Van Slyke and Chapman. Report of the committee on cliemical stanclards. Pediatrics, Vol. XX, 1908, No. 7, p. 455.

4. Gier. Our experience with certified milk in Cincinnati. Kéntucky Med. Jour., Vol. VI, 1908, p. 276.

5. Goler. But a thousand a year. Charities, August 5, 1905.

6. Golfer. Scheme for the sanitary control of the municipal nink supply. Paper read at the Congrès Internalionale des Gouttes de Lait, Paris, 1905.

7. Kerr. Certified milk and infants' milk depots. Bul. No. 41, Hyg. Lab., U.S. Pub. Health and Mar. Hosp. Serv., Washington, D. C., 1908 , p. 565. 
8. LANF. Medical milk connuissions and the production of certified milk in the United States. Bul. No. 10t, Bur. Anim. Ind., I . S. Dept. Agr., Washington, D. C.., 1908.

9. MCCriARY. Infant nortality and infants' nilk depots. London: P. S. King \& Son, 1905.

10. MCCI,EARY. The infants' nilk rlepot. Its 'history and function. Jour. IIyg., Vol. IV, 1904, p. 329.

11. PEARSOn, Lionard. Report of the committee on the inspection of herds and farms used for the production of certified milk. Pediatrics, Vol. XX, 1908, No. 8, p. 500.

12. PHARson, R. A. Market milk: A plan for its improvenent. Serenteenth Ann. Rept. Bur. Anim. Ind., I. S. Dept. Agr., Washington, D. C., 1900 , p. 158.

13. TULEY. Legislation as a factor in the production of clean 1111k. Pediatrics, Vol. XX, 1908, No. 8, p. 487.

14. WARD. Milk production under hygienic conditions. Occidental Medical Journal, Vol. XVI, 1902, p. 178. 


\section{CHAPTER X.}

\section{THE ANALYSIS OF MILK.}

Introduction. In addition to the data obtained from the sanitary inspection of dairies, the health officer should be in a position to inform himself as to the composition of the milk as sold. It is with a view to supplying such necessary aid that these two chapters are here presented. It is not intended to offer full and complete details for the analysis of milk but rather to give some simple and at the same time accurate and reliable tests for ascertaining not only the fat content but also whether or not a milk has been in any way sophisticated. For further details the reader is directed to the standard works mentioned at the end of the chapter.

Composition of milk. Normal cow's milk contains water and the four nutrients, protein, fat, carbohydrate and ash or mineral matter.

Protein. Casein is the chief proteid of milk, constituting fully $80 \%$ of the total amount, the next in importance being albumen present to the amount of $15 \%$. The remaining $5 \%$ consists of different nitrogenous compounds, as lactoglobulin, galactin, fibrin, etc.

The protein content of normal herd milk does not vary greatly, but that of individual cows has been known to range from $2.07 \%$ to $6.69 \%$.

Fat. This is the most variable ingredient of milk. It does not occur in solution but is found suspended in the form of minute globules. These vary in size not only with the milk of the different breeds but also with the same breed or individual during the period of lactation. It is a well known fact that the Channel Island breeds, Jerseys and Guernseys, yield milk showing the highest fat content and the Holstein-Friesian cattle as a rule produce milk of a low fat content. 
The fat percentage of milk not only varies with the different breeds but also in different portions of the same milking, as shown in the following table from Aikman (1).

TABIE VII.

VARIATION OF SOLIDS IN DIFFEREN'T POR'TIONS OF ONE MIIKING.

\begin{tabular}{|c|c|c|c|c|c|c|}
\hline PORTION. & FIRST. & SECOND. & THIRD. & FOURTH. & FIFTH. & SIXTh. \\
\hline Total solids. & $\begin{array}{c}\text { Per cent. } \\
10.47\end{array}$ & $\begin{array}{c}\text { Per cent. } \\
10.75\end{array}$ & $\begin{array}{c}\text { Per cent. } \\
10.85\end{array}$ & $\begin{array}{c}\text { Per cent. } \\
11.23\end{array}$ & $\begin{array}{c}\text { Per cent. } \\
11.63\end{array}$ & $\begin{array}{c}\text { Per cent. } \\
12.67\end{array}$ \\
\hline Fat & 1.70 & 1.76 & 2.10 & 2.54 & 3.14 & 4.08 \\
\hline Solids not fat & 8.77 & 8.99 & 8.75 & 8.69 & 8.49 & 8.59 \\
\hline
\end{tabular}

It must be borne in mind that in mixed herds the product varies in fat percentage to a considerable degree. Some bottles or even cans will be unnecessarily rich in fats at the expense of others which will run below standard. This circumstance may result in the condemnation of the milk, due entirely to careless manipulation, when the average of the herd may be entirely satisfactory. The whole output of a herd at one milking is not mixed in one receptacle and then transferred to cans or bottles. The usual practice is to take the milk of a few cows at a time for bottling. Even under these circumstances there is danger that the fat will rise in the vat under the cooler unless the milk is bottled immediately after cooling. Too much emphasis cannot be placed upon this important point in the handling of any milk and especially with reference to the product of certified dairies. This milk; so frequently modified for infant feeding, should be of uniform composition.

The difficulties encountered are best obviated by alternating in the stable, or in the order of milling, the cows known to yield milk of high fat content with those known to give poor milk. In the case of the Channel Island breeds and the Holstein-Friesians this is a simple matter. In the case of scrub cows this recognition may not be so easy and dependence must be placed upon the results of the examination of the milk of these cows for fat by the Babcock test. 
Carbohydrates. Milk sugar, the carbohydrate of milk, constitutes between $4.5 \%$ and $5 \%$ of the milk.

Mineral matter. The ash, as stated by Leach (2), does not represent the true mineral content of milk, since in the process of incineration some of the constituents are altered. For instance, citric acid occurring in small quantities in normal milk will appear in the ash as carbonic acid in combination. Several other illustrations conld be given.

The ash, in all probability, is the least variable of any of the ingredients of milk and for that reason is often made the basis of calculating the composition of an original milk from the analytical results of the examination of a condensed milk.

Solids of milk. The protein, fat, sugar and ash comprise what are designated as milk solids. The sugar, protein and mineral matter constitute the solids not fat. These latter, with the water, are known as the milk serum.

The average composition of milk, its derivatives and colostrum, are shown in the following table.

TABLE VIII.

COMPOSITION OF MILK, ETC.

\begin{tabular}{|c|c|c|c|c|c|c|}
\hline Constituents & WATER. & FAT. & SUGAR. & PROTEIN. & Ash. & AUTHORITY. \\
\hline & Per cent. & Per cent. & Per cent. & Per cent. & Per cent. & \\
\hline Milk & 87.3 & 3.6 & 4.6 & 3.8 & .7 & Babcock. \\
\hline Skim-milk. & 90.3 & .1 & 5.2 & 3.6 & .8 & Van Slyke. \\
\hline Buttermilk & 91.0 & .5 & 4.8 & 3.0 & .7 & Atwater. \\
\hline Cream... & 68.8 & 22.7 & 4.2 & 3.8 & .5 & König. \\
\hline Colostrum .... & 74.5 & 3.6 & 2.7 & 17.6 & 1.6 & König. \\
\hline
\end{tabular}

Effect of feeding on the composition of milk. The idea is prevalent among dairymen throughout the country that the quality of the milk may be improved by modification of the feeding of the cows. The problem has been investigated many times by eminent authorities. Conclusions have been reached as follows :

1. If a cow is being properly fed, that is, receiving a balanced ration suitable for her individual needs, the quality of the milk 
is not appreciably affected by an increase of any of the ingredients of the ration.

2. Under such circumstances fat cannot be fed into milk.

Sampling milk. The first consideration in the exannination of milk is the sampling. It is of the utmost importance that a representative sample be taken and too much emphasis cannot be placed on this point. Great care is called for in sampling milk because, as previously stated, the fat of milk is not in solution, but held in suspension, and forms an emulsion with the milk serum. The little globules of fat commence to rise very soon after milk is allowed to stand and, to the uninitiated, surprisingly fast. The writer has analyzed three different samples of milk from the same herd showing respectively $2.9 \%, 9.1 \%$ and $3.6 \%$ fat. The variations were due entirely to improper sampling. The sample should be taken and the examination conducted while the milk is fresh and in normal condition. If the samples are to be transported to any distance previous to being tested, care should be taken to see that the bottles are completely filled. This will avoid the tendency to churn which might cause the fat to collect in lumps and prevent, at times, an accurate determination of the fat.

After a sample is properly taken it should be thoroughly mixed before it is tested and the respective portions for the different tests should be measured immediately after mixing. If such a practice is not adopted, serious inaccuracies are liable to occur, owing to the rapidity with which the fat globules will rise toward the surface. By far the best way to mix a sample is to pour it from one vessel to another, and the pouring should be done on the side of the vessel and not in the center. If this precaution is not taken an appreciable amount of air will be incorporated in the milk, which will greatly interfere with the accurate measuring of the milk for the Babcock test for fat.

There are on the market several different devices for sampling market milk, such as the Scovell, McKay, and Equity sampling tubes, etc. These with full directions for use may be obtained from dairy supply houses.

Specific gravity. The specific gravity of a thoroughly mixed sample may be most conveniently taken by means of the small 
hydrometer with the thermometer attached. This is about seven inches long and has a range of from 1.000 to 1.060 . There are several different forms of lactometers on the market but they are not any better adapted for milk than is the hydrometer to which reference has just been made. All readings should be made whenever possible at $60^{\circ} \mathrm{F}$. $\left(15.6^{\circ} \mathrm{C}\right.$. $)$. Whenever this cannot be done correction must be made in accordance with the table below, taken from Richmond (12).

TABLE IX.

FOR CORRECTING SPECIFIC GRAVITY TO $60^{\circ} \mathrm{F}$.

\begin{tabular}{|c|c|c|c|c|c|c|c|c|c|c|c|c|}
\hline \multirow{3}{*}{ 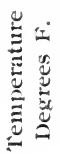 } & \multicolumn{12}{|c|}{ DEGREES OF SPECIFIC GRAVITY OBSERVED. } \\
\hline & 25 & 26 & 27 & 28 & 29 & 30 & 31 & 32 & 33 & 34 & 35 & 36 \\
\hline & & & & \multicolumn{7}{|c|}{ Specific Gravity corrected to $60^{\circ} \mathrm{F}$. } & & \\
\hline 40 & 23.5 & 24.5 & 25.5 & 26.4 & 27.3 & 28.2 & 29.1 & 30.0 & 31.0 & 31.9 & 32.8 & 33.7 \\
\hline 42 & 23.6 & 24.6 & 25.6 & 26.5 & 27.5 & 28.4 & 29.3 & 30.2 & 31.1 & 32.0 & 32.9 & 33.9 \\
\hline 44 & 23.8 & 24.8 & 25.8 & 26.7 & 27.7 & 28.6 & 29.5 & 30.4 & 31.3 & 32.2 & 33.1 & 34. \\
\hline 46 & 23.9 & 24.9 & 25.9 & 26.8 & 27.8 & 28.7 & 29.6 & 30.5 & 31.4 & 32.4 & 33.3 & 34. \\
\hline 48 & 24.0 & 25.0 & 26.0 & 26.9 & 27.9 & 28.8 & 29.7 & 30.6 & 31.6 & 32.6 & 33.5 & 34. \\
\hline 50 & 24.1 & 25.1 & 26.1 & 27 & 28.0 & 29.0 & 29.9 & 30.9 & 31.8 & 32.8 & 33.7 & 34.7 \\
\hline 52 & 24.3 & 25.2 & 26.2 & 27.2 & 28.1 & 29.1 & 30.1 & 31.1 & 32.0 & 33.0 & 33.9 & 34. \\
\hline 54 & 24.5 & 25.4 & 26.4 & 27.4 & 28.4 & 29.3 & 30.3 & 31.3 & 32.3 & 33.3 & 34.2 & 35.1 \\
\hline 56 & 24.6 & 25.6 & 26.7 & 27.6 & 28.6 & 29.6 & 30.5 & 31.5 & 32.5 & 33.5 & 34.4 & 35.4 \\
\hline 58 & 24.8 & 25.8 & 26.8 & 27.8 & 28.8 & 29.8 & 30.8 & 31.7 & 32.7 & 33.7 & 34.7 & 35.7 \\
\hline 60 & 25.0 & 26.0 & 27.0 & 28.0 & 29.0 & 30.0 & 31.0 & 32.0 & 33.0 & 34.0 & 35.0 & 36. \\
\hline 62 & 5.2 & 26. & 27. & 2 & 29.3 & 30.3 & 31.3 & 32.3 & 33.3 & 34.3 & 35.3 & \\
\hline 64 & 5.4 & 26. & 27 & 28 & 29.5 & 30.5 & 31.5 & 32.6 & 33.6 & & 35.6 & \\
\hline 66 & 25.6 & 26.7 & 27.7 & 28.7 & 29.8 & 30.8 & 31.8 & 32.9 & 33.9 & 34.9 & 35 & \\
\hline 68 & 25. & 27.0 & 28. & 29 & 30.1 & 31.1 & 32.1 & 33.2 & 34.2 & 35.2 & 36.2 & \\
\hline 70 & 26. & 27. & 28. & 29. & 30.3 & 31.3 & 32.4 & 33.4 & 34.5 & 35 & & \\
\hline 72 & 26. & 27.4 & 28.4 & 29.5 & 30.5 & 31.6 & 32.6 & 33.7 & 34.7 & 35.8 & & \\
\hline 74 & 26. & 27.7 & 28.7 & 29.7 & 30.8 & 31.9 & 32.9 & 34.0 & 35,0 & 36 & & \\
\hline 76 & 26. & 27. & 28. & 29 & 31. & 32.2 & 33.3 & & 35. & & & \\
\hline 78 & 27. & 28. & 29. & 30 & 31. & 32.5 & 33.6 & 34.7 & 35.8 & 36.9 & & \\
\hline 80 & 27.4 & 28.4 & 29.5 & 30.6 & 31.7 & 32.8 & 33.9 & 35.0 & 36.0 & & & \\
\hline
\end{tabular}

The specific gravity of milk from normal, healthy cows will vary from 1.029 to 1.035 at $60^{\circ} \mathrm{F}\left(15.6^{\circ} \mathrm{C}\right)$. The average for normal milk as determined by the writer from a large number of samples agrees well with the figures obtained elsewhere, namely 1.032. Too much stress cannot be placed on the specific gravity determination, because it is a simple matter to add 
water to milk and then some easily soluble material to bring the gravity back to the normal. Nevertheless, the determination of the gravity is of great assistance to the health officer and physician.

The use of the determination of the specific gravity in the detection of added water is discussed in Chap. XI.

Determination of $\mathrm{fat}$ in milk and cream. Fat being the most variable ingredient of milk, it is only logical that all commercial transactions relative to milk should be based upon the fat content. It was this that gave the incentive to a number of agricultural chemists twenty years ago, upon the establishment of the agricultural experiment stations, to devise a simple, rapid and accurate method for the determination of fat, which could be intelligently used by those who either had no training in chemistry or could not obtain access to a chemical laboratory. The method now in common use is the one given free to the public in 1890 by Dr. S. M. Babcock of the Wisconsin Agricultural Experiment Station. The details of this admirable test are hardly called for here; for such, and other valuable and useful data, the reader is referred to that excellent little work, "'Testing Milk and Its Products,' by Farrington and Woll (5). Also, to "Modern Methods of Testing Milk and Milk Products,' by Van Slyke (14).

It may be said, however, in supplementing the directions usually given for this test that the addition of $2 \mathrm{cc}$. of an $80 \%$ solution of glycerin, as recommended by Holm (7), to the milk in the test bottle just previous to adding the acid will insure a clearer line of demarcation than is ordinarily obtained between the fat and water in the graduated neck of the bottle.

Another modification which has proved useful in the testing of cream by the Babcock method is that obtained by Eckles and Wayman of the Dairy Department of the University of Missouri. It consists in dropping a small quantity of amyl alcohol colored with fuchsin or any red dye on top of the column of butter fat before it is read. Since it is lighter than the fat, it floats on the surface. This removes the meniscus from the surface of the fat to the top of the amyl alcohol, and leaves a perfectly straight line across the top of the fat column. Thus 
the reading of the fat is made more accurately than when an attempt is made to read either to the bottom or center of the meniscus.

It is best to read the fat column immediately after the addition of the alcohol, because, if the latter is allowed to remain in the fat column for several hours, it mixes with the fat to a certain extent and the reading cannot then be taken accurately ; but this does not occur short of two hours. 'This modification has proven of great assistance in the manipulation of the Babcock test for the determination of fat in cream and gives results which compare very favorably with the gravimetric method and the ordinary way of reading the fat column in the Babcock bottle. Webster (15) has made a very exhaustive study of the testing of fat in cream by the Babcock test.

In the hands of a competent operator, the Babcock test gives as reliable and accurate results as those obtained by the con1plicated ether extraction method.

Interpretation of specific gravity and fat. It is almost impossible to lay down any hard and fast rules concerning the interpretation to be placed upon the specific gravity and fat content. It may be said in general with reference to milk from herds in normal condition that:

1. High gravity with high fat content indicates a rich milk.

2. High gravity with low fat content indicates either a poor milk or that the milk has been skimmed.

3. Low gravity with high fat content indicates " top milk," that is, the sample has been taken from a quantity of milk which has been allowed to stand some time previous to sampling.

4. Low gravity, in connection with low fat content, indicates a watered milk.

Solids not fat. While it is true in many instances that the fat per cent. and specific gravity are sufficient to enable the inspector to judge of the quality of milk, at the same time it is a simple matter to obtain the solids not fat by calculation. Formulas for such calculation have been worked out by Babcock, Fleischmann, Richmond and others. The one in general use in this country is Babcock's formula. 
TABLE $X$.

PER CENT. OF SOLIDS NOT FAT, CORRESPONDING TO 0 TO 6 PER CENT. OF FAT, AND SPINDLE READINGS OF 26 TO 36.

\begin{tabular}{|c|c|c|c|c|c|c|c|c|c|c|c|c|}
\hline \multicolumn{13}{|c|}{ SPINDI,E RFADINGS A'T $60^{\circ} \mathrm{F}$. } \\
\hline & 26 & 27 & 28 & 29 & 30 & 31 & 32 & 33 & 34 & 35 & 36 & \\
\hline 0.0 & 6.50 & 6.75 & 7.00 & 7.25 & 7.50 & 7.75 & 8.00 & 8.25 & 850 & 8.75 & 9.00 & 0.0 \\
\hline 0.1 & 6.52 & 6.77 & 7.02 & 7.27 & 7.52 & 7.77 & 8.02 & 827 & 852 & 8.77 & 9.02 & 0.1 \\
\hline 0.2 & 6.54 & 6.79 & .7 .04 & 7.29 & 7.54 & 7.79 & 8.04 & 8.29 & 8.54 & .8 .79 & 9.04 & 0.2 \\
\hline 0.3 & 6.56 & 6.81 & 7.06 & 7.31 & 7.56 & 781 & 8.06 & 831 & 8.56 & $88 \mathrm{I}$ & 9.06 & 0.3 \\
\hline 0.4 & 6.58 & 6.83 & 7.08 & 7.33 & 7.58 & 78.3 & 8.08 & & 858 & 8.83 & 9.08 & 0.4 \\
\hline 0.5 & 6.60 & 6.85 & 7.10 & 7.35 & 7.60 & 785 & 810 & 8.35 & 860 & 8.85 & 9.10 & 0.5 \\
\hline 0.6 & 6.62 & 6.87 & 7.12 & 7.37 & 7.62 & 787 & 8.12 & 8.37 & 862 & 8.87 & 9.12 & 0.6 \\
\hline 0.7 & 6.64 & 6.89 & 7.14 & 7.39 & 7.64 & 7.89 & 8.14 & 839 & 864 & 8.89 & 914 & 0.7 \\
\hline 0.8 & 6.66 & 6.91 & 7.16 & 7.41 & 7.66 & 7.91 & 8.16 & 8.41 & 8.66 & 8.91 & 916 & 0.8 \\
\hline 0.9 & 6.68 & 6.93 & 7.18 & 7.43 & 7.68 & 7.93 & 818 & 843 & 868 & 8.93 & 918 & 0.9 \\
\hline 1.0 & 6.70 & 6.95 & 7.20 & 7.45 & 7.70 & 795 & 8.20 & 8.45 & 8.70 & 895 & 9.20 & 1.0 \\
\hline 1.1 & 6.72 & 6.97 & 7.22 & 7.47 & 7.72 & 797 & 8.22 & 8.47 & 872 & 8.97 & 9.22 & 1.1 \\
\hline 1.2 & 6.74 & 6.99 & 7.24 & 7.49 & 7.74 & 7.99 & 824 & 849 & 874 & 8.99 & 9.24 & 1.2 \\
\hline 1.3 & 6.76 & 7.01 & 7.26 & 7.51 & 7.76 & 801 & 8.26 & 851 & 8.76 & 901 & 9.26 & 1.3 \\
\hline 1.4 & 6.78 & 7.03 & 7.28 & 7.53 & 7.78 & 803 & 828 & 853 & 878 & 9.03 & 928 & 1.4 \\
\hline 1.5 & 6.80 & 7.05 & 7.30 & 7.55 & 7.80 & 805 & 830 & 8.55 & 880 & 905 & 9.30 & 1.5 \\
\hline 1.6 & 6.82 & 7.07 & 7.32 & 7.57 & 7.82 & 807 & 832 & 8.57 & 882 & 9.07 & 932 & 1.6 \\
\hline 1.7 & 6.84 & 7.09 & 7.34 & 7.59 & 7.84 & 8.09 & 834 & 859 & 884 & 9.09 & 9,34 & 1.7 \\
\hline 1.8 & 6.86 & 7.11 & 7.36 & 7.61 & 7.86 & 8,11 & 8.36 & 8.61 & 886 & 911 & 937 & 1.8 \\
\hline 1.9 & 6.88 & 7.13 & 7.38 & 7.63 & 7.88 & 8.13 & 8.38 & 863 & 888 & 9.13 & 9.39 & 1.9 \\
\hline 2.0 & 6.90 & 7.15 & 7.40 & 7.65 & 7.90 & 815 & 8.40 & 8.66 & 891 & 9.16 & 9.41 & 2.0 \\
\hline 2.1 & 6.92 & 7.17 & 7.42 & 7.67 & 7.92 & 817 & 842 & 868 & 893 & 918 & 943 & 2.1 \\
\hline 2.2 & 6.94 & 7.19 & 7.44 & 7.69 & 7.94 & 8.19 & 8.44 & 8.70 & 895 & 9.20 & 945 & 2.2 \\
\hline 2.3 & 6.96 & 7.21 & 7.46 & 7.71 & 7.96 & 821 & 846 & 8.72 & 897 & 922 & 947 & 2.3 \\
\hline 2.4 & 6.98 & 7.23 & 7.48 & 7.73 & 7.98 & 823 & 8.48 & 8.74 & 899 & 9,24 & 949 & 2.4 \\
\hline 2.5 & 7.00 & 7.25 & 7.50 & 7.75 & 8.00 & 8.25 & 850 & 876 & 901 & 9.26 & 951 & 2.5 \\
\hline 2.6 & 7.02 & 7.27 & 7.52 & 7.77 & 8.02 & 827 & 852 & 878 & 903 & 928 & 953 & 2.6 \\
\hline 2.7 & 7.04 & 7.29 & 7.54 & 7.79 & 8.04 & 8.29 & 854 & 880 & 905 & 9.30 & 955 & 2.7 \\
\hline 2.8 & 7.06 & 7.31 & 7.56 & 7.81 & 8.06 & 831 & 8.57 & 882 & 907 & 932 & 9.57 & 2.8 \\
\hline 2.9 & 7.08 & 7.33 & 7.58 & 7.83 & 8.08 & 833 & 858 & 8.84 & 909 & 934 & 9.59 & 2.9 \\
\hline 3.0 & 7.10 & 7.35 & 7.60 & 7.85 & 8.10 & 8.36 & 8.61 & 8.86 & 911 & 936 & 9.61 & 3.0 \\
\hline 3.1 & 7.12 & 7.37 & 7.62 & 7.87 & 8.13 & 838 & 863 & 8.88 & 913 & 938 & 964 & 3.1 \\
\hline 3.2 & 7.14 & 7.39 & 7.64 & 7.89 & 8.15 & 8.40 & 865 & 8 s, 0 & 9.15 & 941 & 9.66 & 3.2 \\
\hline 3.3 & 7.16 & 7.41 & 7.66 & 7.92 & 8.17 & 842 & 8.67 & 892 & 918 & 943 & 968 & 3.3 \\
\hline 3.4 & 7.18 & 7.43 & 7.69 & 7.94 & 8.19 & 8.44 & 869 & 894 & 9.20 & 9.45 & 9.70 & 3.4 \\
\hline 3.5 & 7.20 & 7.45 & 7.71 & 7.96 & 8.21 & 846 & 871 & 8.96 & 922 & 9.47 & 9.72 & 3.5 \\
\hline 3.6 & 7.22 & 7.48 & 7.73 & 7.98 & 8.23 & 8.48 & 873 & 898 & 924 & 9.49 & 974 & 3.6 \\
\hline 3.7 & 7.24 & 7.50 & 7.75 & 8.00 & 8.25 & 850 & $8 \div 5$ & 900 & 926 & 9.51 & 976 & 3.7 \\
\hline 3.8 & 7.26 & 7.52 & $7.7 ?$ & 8.02 & 8.27 & 852 & 877 & 902 & 9.28 & 9.53 & 978 & 3.8 \\
\hline 3.9 & 7.28 & 7.54 & 7.79 & 8.04 & 8.29 & 8.54 & 8.79 & 904 & 930 & 955 & 980 & 3.9 \\
\hline 4.0 & 7.30 & 7.56 & 7.81 & 8.06 & 8.31 & 856 & 881 & 9.06 & 932 & 957 & 9.83 & 4.0 \\
\hline 4.1 & 7.32 & 7.58 & 7.83 & 8.08 & 8.33 & 858 & 8.83 & 908 & 934 & 9.59 & 9.85 & 4.1 \\
\hline 4.2 & 7.34 & 7.60 & 7.85 & 8.10 & 8.35 & 8.60 & 885 & 911 & 936 & 962 & 987 & 4.2 \\
\hline 4.3 & 7.36 & 7.62 & 7.87 & 8.12 & 8.37 & 862 & 8.88 & 9.13 & 9.38 & .964 & 989 & 4.3 \\
\hline 4.4 & 7.38 & 7.64 & 7.89 & 8.14 & 8.39 & 864 & 890 & 9.15 & 9.40 & 966 & 991 & 4.4 \\
\hline 4.5 & 7.40 & 7.66 & 7.91 & 8.16 & 8.41 & 8.66 & 8.92 & 9.17 & 942 & 968 & 993 & 4.5 \\
\hline 4.6 & 7.43 & 7.68 & 7.93 & 8.18 & 8.43 & 8.68 & 894 & 9.19 & 9.44 & 970 & 995 & 4.6 \\
\hline 4.7 & 7.45 & 7.70 & 7.95 & 8.20 & 8.45 & 8.70 & 896 & 9.21 & 9.46 & 9.72 & 997 & 4.7 \\
\hline 4.8 & 7.47 & 7.72 & 7.97 & 8.22 & 8.47 & 872 & 8.98 & 9.23 & 948 & 9.74 & 9.99 & 4.8 \\
\hline 4.9 & 7.49 & 7.74 & 7.99 & 8.24 & 8.49 & 8.74 & 9.00 & 9.25 & 9.50 & 976 & 10.01 & 4.9 \\
\hline 5.0 & 7.51 & 7.76 & 8.01 & 8.26 & 8.51 & 8.76 & 9.02 & 9.27 & 952 & 978 & 10.03 & 5.0 \\
\hline 5.1 & & 7.78 & 8.03 & 8.28 & 8.53 & 8.79 & 904 & 9.29 & 95 & 980 & 10.05 & 5.1 \\
\hline 5.2 & 7.5 & 7.80 & 8.05 & 8.30 & 8.55 & 8.81 & 906 & 9.31 & 9.56 & 9.82 & 10.07 & 5.2 \\
\hline 5.3 & 7.57 & .7 .82 & 8.07 & 8.32 & 8.57 & 8.83 & 9.08 & 9.33 & 958 & 984 & 10.09 & 5.3 \\
\hline 5.4 & 7.59 & 7.84 & 8.09 & 8.34 & 8.60 & 8.85 & 910 & 9.36 & 9.61 & 9.86 & 10.11 & 5.4 \\
\hline 5.5 & 7.61 & 7.86 & 8.11 & 8.36 & 8.62 & 887 & 912 & 9.38 & 963 & 9.88 & 10.13 & 5.5 \\
\hline 5.6 & 7.63 & 7.88 & 8.13 & 8.39 & 8.64 & 8.89 & 9.15 & 9.40 & 965 & 990 & 10.15 & 5.6 \\
\hline 5.7 & 7.65 & 7.90 & 8.15 & 8.41 & 8.66 & 8.91 & 9.17 & 9.42 & 967 & 992 & 10.17 & 5.7 \\
\hline 5.8 & 7.67 & 7.92 & 8.17 & 8.43 & 8.68 & 8.94 & 9.19 & 9.44 & 969 & 994 & 10.19 & 5.8 \\
\hline 5.9 & $7: 69$ & 7.94 & 8.20 & 8.45 & 8.70 & 8.96 & 921 & 9.46 & 971 & 996 & 10.22 & 5.9 \\
\hline 6.0 & 7.71 & 7.96 & 8.22 & 8.47 & 8.72 & 8.98 & 9.23 & 9.48 & 9.73 & 9.98 & 10.24 & 6.0 \\
\hline
\end{tabular}


Table X, page 181, based upon this formula and taken from Farrington and Woll, shows the solids not fat and spindle readings of 26 to 36 . The spindle readings refer to the last two figures of the specific gravity ; for instance, if the specific gravity were 1.032 , this would be represented in the table by spindle reading 32 .

It is thus seen that by adding the fat and solids not fat the total solids of the milk are obtained. In nearly all cases the difference between the actual determination of the solids not fat and the figure obtained by calculation does not differ materially. The inspector consequently by merely determining the fat and the gravity will be in a position to judge whether or no milk under examination is or is not up to the required standard for pure milk.

Preliminary tests of milk. It is often desirable to make preliminary tests of $m i 1 \mathrm{k}$ with reference to its quality, for which there are to be obtained several devices. These are well described by Wing (6), who also gives a very interesting summary of the development of the tests for fat previous to the invention of the Babcock test.

Acidity of milk. This is a point which should receive more attention from the health officer than it ordinarily does. Milk fresh from the cow avill often show an amphoteric reaction but soon afterwards it will show an acid reaction and this acidity will vary greatly, depending entirely upon how the milk has been handled. The Committee on Chemical Standards of the American Association of Medical Milk Commissions recommended that the maximum acidity of milk allowed should be $0.18 \%$ calculated as lactic acicl. The writer considers this to be a very generous standard.

The acidity of milk should be determined at times but not as a routine procedure. This may very easily be done by the use of the Farrington alkaline tablet test as fully described in Farrington and Woll (6). The test is very simple and does not require an expensive outlay for apparatus, but it must be emphasized that only distilled water or a clean, non-alkaline soft water should be used for dissolving the tablets. 
A high acidity indicates bacterial changes, the result of some combination of the factors of uncleanliness, poor refrigeration and age.

Federal standards. In connection with the enforcenient of the pure food and drugs act, the following standards proclaimed by the Secretary of Agriculture have been adopted (13).

\section{MILK AND ITS PRODUC'TS.}

\section{a. MII,K.}

1. Milk is the fresl, clean, lacteal secretion obtained by the complete milking of one or more healthy cows, properly fed and kept, excluding that obtained within fifteen days before and ten days after calving, and contains not less than eight and one-half (8.5) per cent of solids not fat, and not less than three and one-quarter (3.25) per cent of milk fat.

2. Blended milk is milk modified in its composition so as to have a definite and stated percentage of one or more of its constituents.

3. Skim milk is milk from which a part or all of the cream has been removed and contains not less than nine and one-quarter (9.25) per cent of milk solids.

4. Pasteurized milk is milk that has been heated below boiling but sufficiently to kill most of the active organisms present and immediately cooled to $50^{\circ}$ Fahr. or lower.

5. Sterilized milk is milk that has been heated at the temperature of boiling water or higher for a length of time sufficient to kill all organisms present.

6. Condensed milk, evaporated milk, is milk from which a considerable portion of water has been evaporated and contains not less than twenty-eight (28) per cent of milk solids of which not less than twentyseven and five-tenths (27.5) per cent is milk fat.

7. Sweetened condensed milk is milk from wlich a considerable portion of water lias been evaporated and to which sugar (sucrose) has been added, and contains not less than twenty-eight (28) per cent of milk solids, of which not less than twenty-seven and five-tenths (27.5) per cent is milk fat.

8. Condensed skim milk is skim milk from which a considerable portion of water lias been evaporated.

9. Buttermilk is the product that remains when butter is renoved from milk or cream in the process of churning.

10. Goat's milk, ezve's milk, et cetera, are the fresh, clean, lacteal secretions, free from colostrum, obtained by the complete milking of healthy animals other than cows, properly fed and kept, and conform in name to the species of animal from which they are obtained. 


\section{b. CREAM.}

1. Cream is that portion of milk, rich in milk fat, which rises to the surface of nilik on standing, or is separated from it by centrifugal force, is fresh and clean and contains not less than eighteen (18) per cent of 111 ilk fat.

2. Ezaporated cream, clotted cream, is cream from which a considerable portion of water has been evaporated.

State standards. In drafting local dairy ordinances it is desirable to have the standards conform to the requirements of the state law. In California, the courts have ruled that the city ordinances can conflict with those of the state to the extent of raising the local standard above that adopted by the state.

Collection of samples. One of the most important and weighty considerations is the proper collection of milk samples. This necessitates the employment of trained inspectors. It would appear from the experience of the writer that this point is not ordinarily kept in mind when officers are appointed. The inspector should either be a dairy-school graduate well recommended or should receive the necessary training in the laboratory with which he is to be associated.

Samples from milk cans, whether from store or wagon, should be collected with care in the matter of mixing as pointed out on page 177. An additional precaution regarding the use of the sampling tube might not be out of place. The tube should be thoroughly rinsed after each sample has been taken in order to preclude the possibility of contaminating one sample with traces of a preservative that might have been in the previous one.

One of the most convenient receptacles for collecting milk is a wide-mouthed eight-ounce bottle with a well-fitted cork. Duplicate samples should be collected in order that the party from whom the sample is taken may retain one for analysis if he so desires. Dairy ordinances should require that this be done.

In the case of bottled milk also it would appear to be desirable to collect duplicate samples. This may readily be done by the inspector carrying in his outfit a clean quart bottle for 
mixing samples. He would thus be enabled to thoroughly mix the contents of a sample of bottled milk in the presence of the vender and to give half to the vender as a duplicate. If this method is followed there can be no dispute as to the authenticity of the samples collected.

It is highly essential that the inspector be provided with a book of numbered blank forms containing also small slips bearing duplicate numbers. One of these slips should go on each sample for purposes of identification. The blanks should call for information covering the essential facts regarding the source of the sample and should be in duplicate. The inspector retains the original in his book and the duplicate goes with the sample to the chemist.

All samples must be duly sealed in the presence of the vender. This may be done by the use of gummed paper strips printed with an appropriate legend and pasted over the cork. The seal bears a printed number corresponding to that of the blank form. Sealing wax impressed with a distinctive device may also be used for the purpose of sealing the sample. In this case the cork must be flush with the top of the neck of the bottle, for the wax is sweared over both.

\section{REFER ENCES.}

1. Arkman. Milk, its nature and composition. London: Adlan and Charles Black, 1899.

2. Alt,en. Commercial organic analysis. Vol. IV. Philadelphia : P. Blakiston's Son \& Co., 1898.

3. ATwATER and Bryant. Chemical composition of American food 111aterials. Bu!. No. 28 (rezised), Office of Exp. Sta., L. S. Dept. Agr., Washington, D. C., 1906.

4. Bi,YTH. Foods, their composition and analysis. London: Cli. Griffin \& Co., Ltrl., 1903.

5. FARRING'TON and WOI. Testing milk and its products. Madison, Wis.: Menclota Book Co., 1908.

6. Harrington. Variations in inilk. Bul. No. 24, I'niz'of Ill. Agr. Exp. Sta., Urbana, I11., 1893. 
7. Hor, A. A new method for preventing char in the Babcock centrifugal determination of fat in milk and milk products. Amer. Food Jour., Vol. II, 1907, No. 7, p. 28.

8. KASTI, and Roberts. The chemistry of milk. Bul. No. $t 1$. Hyg. Lab., l. S. Pub. Health and Mar. Hosp. Serr'., Washington, 1. C.. 1908, p. 309.

9. Langworthy. Milk as food. Farmers' Bul. No.77, I. S. Dept. Agr., Washington, D. C., 1904.

10. LEACH. Food inspection and analysis. New York: John Wiley \& Sons, 1906.

11. Richuond. Dairy chemistry. London: Ch. Griffin \& Co., Ltel.

12. Richuoxin. The laboratory book of dairy analysis. London: Ch. Griffin \& Co., Lttl., 1899.

13. SECRETARY of AGRIClititre. Standards of purity for food products. Cir. No. 19, Office of the Secretary, I. S. Mept. Agr., Washington, D. C., 1906.

14. VAN SirkF. Modern methods of testing milk and milk products. New York: Orange Judd Co., 1906.

15. WEBSTER. The fat testing of cream by the Babcock method. Bul. No. 5s, Bur. Anim. Ind., I. S. Dept. Agr., Washington, D. C., 1902.

16. WILEY (EDITOR). Official and provisional methorls of analysis, Association of Official Agricultural Chemists. Bul. No. 107 (reaised), Bur. of Chem., C. S. Dept. Agr., Washington, I. C., 1908.

17. Wisc. Milk and its products. New York: The Macmillan Co., 1909. 


\section{ADULTERATION OF MILK.}

Introduction. That milk is easily contaminated and subject to deleterious changes, was well known in ancient times. This is prover by a reference to the Talmudic Laws, where the following statement is found: "Milk is one of the beverages that makes the articles of food liable to receive impurities." (3)

It is true that chenical preservatives were not known at that time and consequently were not used. Such materials, however, have been used for many years in milk intended for human consumption and the practice prevails to some extent at the present time.

It may be said that perhaps few questions concerning the public health have provoked more discussion or been productive of more experiments and investigations than that of the use of preservatives in foods intended for human consumption. It is of more than passing interest, and certainly a matter of congratulation, to be able to say that the greater the advance of science, the greater and more powerful is the ammunition brought forward to fight, and successfully too, the advocates of the use of deleterious materials in our food products. These substances, as is well known, are added in many cases for the purpose either of enhancing the value of poor products or preventing or arresting the decay of an already unwholesome food.

The literature abounds in records of investigations of the influence of preservatives on the food value of milk. For a very complete bibliography of this subject, the reader is referred to Kastle and Roberts (4).

Much has been written on both sides of this all-important question. If proper care is exercised in the handling of milk 
intended for human consumption, there is no necessity for the use of preservatives to insure its keeping fresh. This is particularly to be emphasized in the care of milk to be fed to infants and invalids.

While there is much evidence in favor of the use of some of the preservatives for milk, such as boric acid or borax, formaldehyde, hydrogen peroxide, etc., yet most of this evidence is the result of artificial digestion experiments. It is conceded that such investigations are of great scientific value but too much importance must not be attributed to them. There are many conditions which obtain in the natural process of digestion which cannot be duplicated under artificial conditions. A notable instance of the necessity of conducting both the artificial and natural digestion experiments before drawing any final conclusions is recorded by Wiley (6) in his report on the influence of salicylic acid and salicylates on digestion and health.

Wiley states in his conclusions:

"The data show very clearly that salicylic acid and salicylates appear to exert an exciting influence upon the activities which take place in the alimentary canal, stimulating the organs to greater effort, and this stimulation leads at first to increased digestion and absorption of the foods which are introduced into the stomach. In the light of the data which are exhibited, salicylic acid may be said to increase the solubility and absorption of the food in the alimentary canal, so that large parts of the nutrients taken into the stomach actually enter the circulation.

"The data which show the effects just noted also indicate that the general effect upon the system is depressing, in that the tissues are broken down more rapidly than they are built up, and thus the normal netabolic processes are interfered with in a harmful way. The administration of the salicylic acid is attended by a gradual decrease in the weiglit of the subjects, altho the quantity of food elements administered during the preservative and after periods is slightly increased, which fact, together with a greater degree of absorption of the food elements, should have resulted in a slight increase in weight. This increase in weight, however, does not occur, and the disturbing influences of the salicylic acid upon metabolism, altho not very great, are specifically demonstrated.",

The natural inference from an artificial digestion experiment, along the lines indicated, would be that salicylic acid is a 
help rather than a hindrance to digestion of proteids, whereas the inference from the natural digestion experiment is just the reverse.

It is admitted, of course, that it is almost impossible to conduct metabolism experiments with infants as subjects, and they are the very class most concerned. Among the many experiments carried on with very young animals are those of Annett (1). The subject of his experiments were kittens three weeks of age. The milk fed was treated with boric acid. The anounts for the two experiments were respectively 40 and 80 grains of boric acid per gallon of milk. At the end of the four weeks, all kittens fed on the adulterated milk were dead, while the control lot, which were fed pure milk, were alive and healthy.

This series of experiments was followed by a similar one, the milk, however, being treated with formaldehyde in place of boric acid. The results of the latter experiments were not so conclusive as were those obtained from the boric acid test. At the same time, the data obtained are of more than passing interest. In the first experiment, the milk contained 7 parts formaldehyde to 50,000 parts milk. In the second experiment, the proportion of formaldehyde was just doubled, or 1 to 25,000. In the third experiment, the proportion of formaldehyde was again doubled, or 1 part to 12,500 . It was noted that the gain in weight in all three experiments by the control kittens receiving only pure milk was far ahead of the gain of those receiving the adulterated article. This is particularly emphasized in the third experiment. These results are at variance with many of the findings recorded for artificial digestion experiments but as they have stood the test of criticism and investigation they must be accorded serious consideration.

It is perhaps gratifying to know that Annett's views on this subject are ably supported by the reports of Wiley (6) on the influence of food preservatives and artificial colors on digestion and health. 'The subjects of Wiley's experiments were all healthy young men, and it was clearly shown that the preservatives studied, viz., borax, salicylic acid, sulphites and benzoic acid, and formaldehyde, were deleterious substances and produced digestive disturbances. 
In view of the contradictory mass of evidence which is at hand as shown by Kastle and Roberts (4), it would appear that laws forbidding the use of preservatives in milk intended for human consumption are certainly to be recommended as safeguarding the public health. The strong, healthy stomach may and can withstand strains to which the delicate digestive organs of an infant or invalid would succumb.

Tests for preservatives. A complete examination of a sample of milk for preservatives would include tests for boracic acid and its compounds, formaldehyde, fluorids, benzoic acid and its compounds, salicylic acid and salicylates, peroxide of hydrogen, etc. Such thorough analytical work can be conducted only in a well-equipped laboratory. It is assumed that the man in charge of the work is an expert and has at his disposal the necessary standard works describing the tests. For this reason it is not considered necessary to reprint the methods for making such determinations. The preservatives most commonly used are borax and formaldehyde. It is fortunate that there are simple and reliable tests for these two.

Borax. A preliminary test may be made for boric acid and borates by immersing a strip of turmeric paper in about $100 \mathrm{cc}$. of milk to which about $7 \mathrm{cc}$. of concentrated hydrochloric acid has been added. If boric acid or borax is present, the paper on drying will acquire a peculiar red color which is changed by ammonium hydrate to a dark blue-green but is restored by acid. The above mentioned reagents can easily be obtained at a drug store. A positive reaction would indicate the presence of borax but a negative reaction might not in all cases mean that the material does not contain borax but would require further examination where better laboratory facilities could be obtained.

Formaldehyde. This is without doubt the best preservative of milk. So efficacious is this material that there are many compounds to be found on the market under various names, such as "callerine," "freezine," etc. These different preparations are weak solutions of formaldehyde, ranging from about $3 \%$ to $7 \%$ in strength. 
There are two elifferent methods which are easily carried out,-those of Hehner and Leach.

\section{Hehner's test for formaldehyde:}

"To $10 \mathrm{cc}$. of milk in a wide test tube add about half the volume of concentrated conmercial sulphuric acid, pouring the acid carefully down the side of the tube so that it forms a layer at the bottom, without mixing with the milk. A violet zone at the junetion of the two liquids indicates formaldehyde. The coloration produced depends on the presence of a very snill anlount of iron. For this reason the ordinary connuercial acid user in the Babcock test answers well for this test. However, if an excess of formaldehyde is present in the milk, this test will not indicate the presence of the preservative."

\section{Leach's test for formaldehyde:}

"Commercial hydrochloric acid (specific gravity 1.2) containing $2 \mathrm{cc}$. of $10 \%$ ferric chloride per liter is used as a reagent. Add $10 \mathrm{cc}$. of the acid reagent to an equal volume of $111 \mathrm{k}$ in a porcelain casserole, and heat slowly over the free flame nearly to boiling, lolding the casserole by the handle, and giving it a rotary motion while heating to break up the curd. The presence of formaldeliyde is indicated by a violet coloration, varying in depth with the amount present. In the absence of formaldehyde, the solution slowly turns brown. By this test 1 part of formaldeliyde in 250,000 parts of $111 \mathrm{k}$ is rearlily detected before the milk sours. After souring, the limit of delicacy proves to be about 1 part in $50,000 .$,

The porcelain casserole can be obtained at any clienical supply house and the solution as indicated can very easily be nuade up by any druggist. In place of the gas flame, an alcohol lan1p nuy be used. A word of caution must be mentioned with reference to this test, because it is so delicate. In at least one instance the use of absorbent cotton in a strainer at a good dairy resulted in the finding of formaldehyde in the milk. Investigation showed that the cotton had been sterilized with formaldehyde by the manufacturers. The use of formaldehyde in the tubes of milking machines offers like possibilities for the contamination of milk by this chemical.

Watering of milk. One of the more common sophistications of milk is the addition of water. Such a practice is not only a pecuniary fraud but it both lowers the nutritive value and may prove at times to be a menace to health, as discussed in Chapters III and V. 
The effect of the added water is to lower the specific gravity and also the percentage of all the ingredients.

The determination of fat alone is not sufficient to indicate in all cases whether or not water has been added to milk. This could be illustrated by many instances, notably in the case of Jersey milk containing 6\% fat. Such milk could be diluted with $50 \%$ water and at the same time yield $4 \%$ fat. Judged by the fat content alone, the watered milk would be considered of high quality, while the nutritive value would be only two-thirds of the normal. Serious mistakes have been made by modifying for infant feeding just such watered milk, upon the assumption that it was a normal milk containing $4 \%$ fat.

The determination of the specific gravity when the only sophistication of the milk is that of added water, is of great value. A low specific gravity, that is, below 1.028 , with a low fat content, is a very sure indication of added water. When an inspector finds such conditions the sample should be examined by the immersion refractometer. Full directions for using this instrument are to be found in Leach (5). A reading below 39 indicates added water, between 39 and 40 the sample is to be regarded as suspicious. If it is not possible to have access to a refractometer a determination of $111 \mathrm{k}$ sugar will be very helpful. A low sugar content, that is, below $4 \%$, in connection with a low gravity and fat, indicates added water.

Skimming. The removal of the cream is to be considered an adulteration in that the consumer is deceived and misled. Evidence regarding whether or not a given sample of milk has been skimmed is mainly gathered from results of the test for fat. The only cases where this test is not reliable are to be found in the rich milks of the Channel Island breeds, which can be skimmed and still indicate a fat per cent. above many of the legal standards.

Carbonate of soda. This and the bicarbonate are occasionally used to lessen the acidity of old milk. The addition of these compounds to milk is to be considered in that they are added to conceal inferiority. For detection, see Leach (5). 
Thickening agents for cream. Gelatin is added to crean for the purpose of increasing viscosity and giving the appearance of greater richness than is really the case. For detection, see Leach (5).

Sucrate of lime (viscogen) is sometimes used in order to make pasteurized cream whip. It is a harmless adulteration and permissible when the product is so labeled.

Heated milk. Storch has devised a test that will indicate whether milk, cream or other dairy products have been heated to $178^{\circ} \mathrm{F}$. $\left(80^{\circ} \mathrm{C}\right.$. $)$. It is carried out as follows: A teaspoonful of milk is poured into a test tube and one drop of a weak solution of peroxide of hydrogen $(2 \%)$ and two drops of a $2 \%$ solution of paraphenyldiamin are added. The mixture is then shaken. If a dark violet color appears at once, the milk has not been heated, or at any rate, not above $175^{\circ} \mathrm{F}$.

Coloring matter. The chief object of adding coloring matter to milk is for the purpose of concealing either skimming or watering. Two classes of compounds are used, vegetable and coal-tar colors. Some of the latter are harmless, as naphthol yellow S or Orange I, as declared in the U. S. Department of Agriculture, Food Inspection Decision 76. Only a very small amount of coloring matter is used and the effect is generally harmless; but such additions are in violation of the law in that they tend to mislead and deceive the consumer. The detection of added coloring matter in milk cannot very well be undertaken away from a chemical laboratory. Full and complete directions for the testing of milk for the presence of added coloring matter will be found in Bulletin No. 107 (7).

If there is any suspicion that a milk has been adulterated with coloring matter, it should be allowed to stand undisturbed for several hours in a glass vessel. If then the sample exhibits different zones of color, it may safely be said that the milk contains no added coloring matter. The different colors should be the yellow of the cream, which overlies the stratum of a mixture of milk and cream of a lighter color, under which is the bluish layer of skimmed milk. If, on the other hand, the color is more or less uniform throughout the sample, it should be further examined for confirmation. 


\section{REFERENCFS.}

1. ANNETT. Boric acid and formalin as milk preservatives. Lancet, Vol. II, 1899, p. 1282.

2. IDOANE and PRICE. Influence of preservatives on food value of milk. Bul. No: S6, Maryland Agr. Exp. Sta., College Park, Md., 1902.

3. Jewish Encyclopedia, Vol. VIII, 1904, p. 591.

4. KASTrE and RoBERTS. Tle chemistry of milk. Bul. No. 41, Hyg. Lab., L. S. I'ub. Health and Mar. Hosp. Sera'., Washington, D. C., 1908, p. 309.

5. LEACH. Food inspection and analysis. New York: John Wiley \& Sons, 1906.

6. Wisty. Influence of food preservatives and artificial colors on digestion and health. Bul. No. 87, Bur. Chem., I. S. Dept. Agr., Washington, D. C., Part I, 1904; Part II, 1906.

7. WILEY (EDITOR). Official and provisional nethods of analysis, Association of Official Agricultural Chemists. Bul. No. 107 (revised), Bur. Chem., L. S. Dept. Agr., Washington, D. C., 1908. 


\title{
APPENDIX A.
}

\author{
DAIRY ORDINANCE OF BERKELFY, CAI,
}

Ordinanchi No. 495-A.

Providing for the Inspection of Milk, Dairies and Dairy Ilerds, and Regulating the Sale and Disposition of Milk in the Town of Berkeley, and Provirling a Penalty for the Violation of Said Ordinance.

Be it ordained by the Board of 'Trustees of the Town of Berkeley, as follows :

Sec. 1. From and after October 10, 1907, no person shall offer or expose for sale, or sell or deliver for sale or consumption within the Town of Berkeley any milk or cream, without first obtaining and having a permit therefor from the Health Officer in accordance with the conditions in this ordinance lereinafter provided.

Sec. 2. Any person desiring a pernit to engage in the sale or disposition of milk, as provided in Section 1 hereof, shall first make application therefor, to the Health Officer of the 'low'n of Berkeley by filing with the Health Officer an application in writing therefor, which said application shall set forth with reasonable exactness the name and place of residence of the applicant, the exact location or place from which the applicant obtains or is to obtain his milk, and if the applicant is not a producer of milk, then the name of the person or persons from whom he obtains or is to obtain his milk for sale or distribution, and if said applicant is a producer of milk, the number of cows in his dairy herd, or if lie is not a producer of nilk, the number of cows in the dairy herd of the person or persons from whom he obtains or is to obtain his 1nilk; there shall also be filed with the Health Officer the veterinary surgeon's certificate required by Section 6 of this ordinance concurrently with the application heretofore mentioned; and said application shall further set forth the manner in which the applicant intends to dispose of his $111 \mathrm{kik}$ when granted such permit, according to the provisions of this ordinance, and shall be signed by the applicant, and when received by the Health Officer shall be placed on file and the name of the applicant shall be registered in a book of registration kept for such purpose.

Sec. 3. Any such applicant, or any person from whom such applicant obtains, or is to obtain his milk, shall permit the Health Officer of the Town of Berkeley, his assistants and deputies, to inspect the dairy and the dairy lerds of such applicant, or the dairy and dairy herd of the person, or persons, from whom the applicant obtains, or is to obtain 
his 1nilk, by physical examination and the tuberculin test of the cows for the purpose of determining the presence or absence of tuberculosis, together with all appliances and milk vessels used therein, and any refusal upon the part of such applicant, or upon the part of the person or persons from whom such applicant obtains or is to obtain his milk, to permit the inspection above referred to shall be deemed a sufficient ground upon which the Health Officer may refuse to issue the permit applied for, and for such cause may revoke the same after its issuance.

Sec. 4. It shall thereupon be the duty of the Health Officer to issue a permit or permits to sell or distribute milk within the corporate limits of the Town of Berkeley to each applicant who has complied with the requirements of this ordinance, which said permit shall be numbered and signed by the Health Officer, and a record thereof shall be kept in the book of registration provided for in Section 2 lereof, and said pernit shall be valid and effective for the period of one year from and after the date of its issuance, unless sooner revoked by said Health Officer for violation of any of the provisions of this ordinance.

Sec. 5. Each person granted a permit under the provisions of this ordinance shall cause his name and his place of business and the number of his permit to be legibly placed in a conspicuous place on the outer side of all carriages, wagons or other vehicles used by him in the sale or distribution of $111 \mathrm{k}$ within the corporate limits of the Town of Berkeley, and all persons who sell 111ilk from stores or shops shall keep their permit constantly posted in a conspicuous place upon the wall of the room within which such sale of milk is prosecuted or carried on.

Sec. 6. No person shall bring into the Town of Berkeley for sale, either by wagon, cart, train or any other kind of vehicle, or keep, have or offer for sale, or sell in said town, any milk or cream contained in. cans, bottles or packages unless such cans, bottles and packages containing such milk or cream for sale shall be marked with a legible stamp, tag or impression bearing the name of the owner of the cows from which such milk was drawn, giving his place of business, including name of city, street and number, and unless the owner or owners of such cows shall first file in the office of the Health Officer a certificate of a duly licensed veterinary surgeon, stating that sucl cows have been subjected to a physical examination and the tuberculin test for the purpose of detecting the presence or absence of tuberculosis, and shall state the results of his examination of them with reference to the existence of other infectious or contagious diseases. Such certificate shall give a number which has been permanently attaclied to each cow and shall state the date, the place of examination, the temperature of the cow or cows at intervals of three hours for twelve hours before the subcutaneous injection of the tuberculin, the temperature at the tenth hour after the injection of the tuberculin, and every three hours after the aforesaid tenth hour, for twelve hours, or until the reaction is completed. The 
said certificate shall further contain the conclusions of the veterinary surgeon touching the presence or absence of tuberculosis in the animal or animals examined, drawn from the data afforded by the physical examination and the tuberculin test. Said certificate shall be acconnpanied by a description of the animal or animals tested, sufficiently accurate to serve for purposes of identification.

Sec. 7. No milk which is watered, adulterated, reduced or changed in any respect by the addition of water or other substance or by the removal of crean, or milk which has been drawn from cows suffering from tuberculosis or any other contagious disease, or milk which has been drawn from cows which have not been inspected by a duly licensed veterinary surgeon and tested by physical examination and the tuberculin test for the purpose of detecting the presence or absence of tuberculosis, shall be brought into the Town of Berkeley, or held, kept, sold or offered for sale at any place in said town, nor shall any person, persons or corporation keep, have, sell or offer for sale any such milk in said Town of Berkeley, except that milk from which any part of the cream has been renoved may be sold in the manner lereinafter provided.

The term "adulterated milk," as used in this ordinance, means :

First-Milk containing more than eighty-eight per centum of water fluirls.

Second-Milk containing less than twelve (12) per centum of milk solids.

Third-Milk containing less than three (3) per centum of fats.

Fourth-Milk drawn from animals within fifteen (15) days before or five (5) days after parturition.

Fifth-Milk drawn from animals fed on any substance in a state of fermentation or putrification or on any unwholesome food.

Sixth-Milk drawn from cows kept in a crowded or unlealthy condition, or from cows suffering with tuberculosis or any other contagious disease.

Seventl-Milk from which any part of the cream has been removed.

Fighth-Milk which has been diluted with water or any other fluid, or to which has been added, or into which has been introduced. any foreign substance whatever.

Sec. 8. The Health Officer is hereby authorized to provide metal ear tags each marked with the words, "Berkeley Board of Health," and a serial number, and also to provide printed blanks, and is authorized to distribute them to any duly licensed veterinary surgeon who may apply for them for use in compliance with the requirements of Section 6 of this ordinance.

Sec. 9. Notwithstanding the provisions of Section 7 of this ordinance, milk from which the cream has been removed, if sucl milk is otherwise wholesome and unadulteraterl, may be sold as skimmed milk ly dealers having the permit provided for by this ordinance, but only from vessels 
legibly marked, in addition to the stamp, tag, or impression provided for in Section 6 of this ordinance, with the words "Skimmed Milk" in plain black letters upon a light background, and each letter being at least one inch high and one-half inch wide, the said words being placed in a conspicuous place on the top or side of such ressel.

Sec. 10. Any adulterated nilk which has been brought into the Town of Berkeley, or is held and offered for sale in said town, excepting skinmed milk when offered for sale as provided in this ordinance, may he seized and destroyed by an inspector or other officer of the Board of Health of said town authorized to inspect the sane.

Sec. 11. No cream which is adulterated, or that shall contain less than twenty (20) per centum of fat, shall be brought into the Town of Berkeley, or held, kept, sold or offered for sale in said town, nor sliall any one keep, have, sell or offer for sale in said town any such creanl. The term "cream" means the fatty portions of pure milk which rise to the surface when milk is left at rest, or which are separated by other means. The term "crean which is adulterated," as used in this section, means any cream to which any foreign substance has been added.

Sec. 12. The Health Officer and his assistants and deputies shall have authority to stop and inspect, or cause to be inspected, any wagon, cart, train or other velicle used in delivering milk, or any store, depot, shop, creamery or any place where milk is offered for sale or sold, and to take samples of milk from wagons, carts, trains or any other place where milk is sold or offered for sale, for the purpose of enforcing the provisions of this ordinance.

Sec. 13. Milk must not be kept for sale or stored in any stable, or milk-house that is connected with a stable, or in any room used for sleeping or domestic purposes or opening into same, nor in unclean or rusty cans.

Milk must not be transferred from cans to bottles or other vessels on streets or at railroad depots. Milk must not be sold in bottles, except under the following rules:

Bottles must be washed clean with hot water solution of soap or soda, or some other alkali, and then with hot water before filling.

Bottles must not be filled except at the dairy or creamery, and in the town only in rooms so situated as to prevent contamination of the milk by dust or other impurities from the streets or elsewhere.

Bottles must not be washed or filled witl milk in any rooms used for sleeping or domestic purposes, or opening into the same.

The vessels in which milk is kept for sale must be protected by means of a suitable covered receptacle and so placed in the store as to prevent dust from the street or other inpurities falling into it.

All cattle condemned as tuberculous shall be removed from the premises within one week thereafter. 
When any person having a permit hereunder shall sell or deliver to any customer any tickets or tags representing any milk or crean to which the customer is entitled, the same shall be in the form of coupon tickets, or be metal tags, so as to insure cleanliness.

Sec. 14. Nothing herein contained shall be construed to prevent or prohibit the use, sale or manufacture of what is known as condensed milk, or what is known as buttermilk, provided the same are marle, compounded and prepared from milk not lower than the standard provided in this ordinance, and provided further that said condensed milk or buttermilk are in sound, wholesome condition, and provided also that in the case of condensed and dried milks, the properties of milk solids shall be equivalent to twelve (12) per centum of milk solids in crude milk, and that of such solids twenty-five (25) per centum sinall be fat.

Sec. 15. Any person who shall violate any of the provisions or requirements of this ordinance shall be deemed guilty of a misdemeanor and upon conviction thereof, shall be punished by a fine of not less than ten (10) dollars, nor more than two hundred and fifty (250) dollars, or by imprisonment in the county jail of Alameda county for not nore than ninety (90) days; or by both such fine and imprisonment.

The judgment imposing the fine may provide for its collection by in1prisonment in the county jail of Alaneda county for the time and in the manner provided by law.

Sec. 16. All ordinances and parts of ordinances in conflict with the provisions of this ordinance are hereby repealerl.

Sec. 17. This ordinance shall take effect and be in force and effect from and after its final passage.

Sec. 18. This ordinance is hereby ordered to be printed and published (with the ayes and noes) for two days in the Berkeley Daily Gazette, which newspaper is hereby designated for that purpose. 


\section{APPENDIX B.}

\section{CHICAGO TUBERCULIN TEST ORDINANCE AND RULES OF THE, DEPAR'TMFN'T OF HEALTH.}

Ordinances Requiring Tuberculin Test of Ali, Cows Supplying Milk and Milk Prodects.

Be it ordained by the City Council of the City of Chicago:

MIII, K.

SECTION 1. No milk, cream, buttermilk or ice cream shall be sold, offered for sale, exposed for sale or kept with the intention of selling within the City of Chicago after January 1, A. D. 1909, unless such niilk or cream or the millk or cream contained in buttermilk and ice cream, be obtained from cows that have given a satisfactory negative tuberculin test within one year; the cows having been satisfactorily tested sliall be marked "tuberculin tested" and shall be numbered and a certificate shall be filed with the division of milk inspection of the Department of Health of the City of Chicago upon forms furnished by the Commissioner of Health, giving the number, a brief description of the animal, the date of the taking of said test and the name of the owner. Said certificate shall be signed by the person making such test; provided, however, that from January 1, 1909, for a period of five years, to wit, until January 1, 1914 , milk or cream or buttermilk and ice cream made from milk or cream, obtained from cows not tuberculin tested or not free from tuberculosis, may be sold within the City of Chicago if the milk or crean frow1 said cows is pasteurized according to the rules and regulations of the Department of Health of the City of Chicago.

SECTION 2. Any milk, crean, buttermilk or ice cream offered for sale, exposed for sale or kept with the intention of selling within the City of Chicago which shall be found within the City in violation of Section 1, shall be forthwith seized, condemned and destroyed by the milk and food inspectors or other duly authorized agents or employes of the Department of Health of the City of Chicago.

SECTION 3. This ordinance shall be in full force and effect from and after January 1, 1909.

BUTTER.

Be it ordained by the City Council of the City of Chicago:

SFcrion 1. No butter shall be sold or offered for sale or kept with the intention of selling in the City of Chicago after January 1, 1909, un- 
less such butter be made from milk or cream obtained from cows that have given a satisfactory negative tuberculin test within one year; provided, however, that from January 1, 1909, for a period of five years, to wit, until January 1, 1914, butter made of milk obtained from cows not tuberculin tested or not free from tuberculosis may be sold in the City of Chicago if the milk or cream from which such butter was made was pasteurizerl according to the rules and regulations of the Department of Health of the City of Chicago.

Sriction 2. It shall be unlawful to sell any butter in the City of Chicago, unless there be stamped on the package in plainly legible letters of not less than one-eighth-inch type: "Marle of milk (or cream) from cows free from tuberculosis as shown by tuberculin test," or, "Made from milk (or creami) pasteurized according to the rules and regulations of the Department of Health of the City of Chicago."

SECTION 3. Any butter offered for sale, exposed for sale or kept with the intention of selling in the City of Chicago, which shall be found within the city in violation of this ordinance, shall be forthwith seized, condemned and restroyed by the milk and food inspectors or other duly authorized agents or employes of the Department of Health of the City of Chicago.

SECTION 4. This ordinance shall be in full force and effect from and after January 1, 1909.

CHEESE.

\section{Be it ordained by the City Council of the City of Chicago:}

SECTION 1. No domestic cheese shall be sold or offered for sale or kept with the intention of selling in the City of Chicago after January 1 , 1909, unless such cheese be made from nilk or cream obtained from cows that have given a satisfactory negative tuberculin test within one year; proviled, however, that from January 1, 1909, for a period of five years, to wit, until January 1,1914 , domestic clieese made of milk obtained from cows not tuberculin tested or not free from tuberculosis, may be sold in the City of Chicago if the milk or cream from which such cheese was made was pasteurized accorling to the rules and regulations of the Department of Health of the City of Chicago.

Sfiction 2. It shall be unlawful to sell any such cheese in the City of Chicago unless there be stamped on the package in plainly legible letters of not less than one-eighth-incl type: "Marle of milk (or cream) from cows free from tuberculosis as shown by tuberculin test," or "Made from 1 inilk (or cream) pasteurized according to the rules and regulations of the Department of Health of the City of Chicago."

Shction 3. Any cheese offered for sale, exposed for sale or kept with the intention of selling in the City of Chicago, which shall be found within the city in violation of this ordinance, shall be forthwith seized, 
condemned and destroyed by the milk and food inspectors or other duly authorized agents or employes of the Department of Health of the City of Chicago.

SECTION 4. This ordinance shall be in full force and effect from and after January 1, 1909.

\section{RIIAS REgLiatiNG THE TUBFRCIIIN TFSTING OF COWS.}

Rule 1. Who May Make the Test.] Tuberculin tests marle on animals supplying the City of Chicago with milk or milk products may be made by licensed graduate veterinarians, federal or state veterinarians, federal, state or city dairy and milk inspectors and by persons regularly employed by the Chicago Department of Health for that purpose.

Rule 2. The Test to be Finployed.] The regular injection methor of tuberculin testing shall be employed. The temperature shall be taken at least four times on the day preceding the inoculation, and at least six times on the flay following the inoculation, at not less than two hour intervals. A rise of two degrees over the average temperature on the day precerling the inoculation shall be considered a positive test. If a rise of from one and a half to two degrees is obtained, the results shall be considered doubtful, and the animal subjected to a later retest. Animals that have been arlded to the herds within the last six weeks shall be tested by the ordinary injection test supplemented by calmette's Ophthalmic Test, and a positive result with either one or the other shall condemn the animal. The Department of Health shall have the power to require the retesting of all animals subnitted for milk supply by the Calmette Ophthalmic method or any other method to be decirled on in the future.

Rule 3. The Numbering and Tagging of Aninals.] All tested animals shall bear an indestructible tag indicating the series, and also the number assigned to the animal. Tags placed by federal, state and municipal inspectors will designate by abbreviations or otherwise the series represented. Veterinarians supplying the numbered tags nust have their initials or some other distinctive mark appear on the tag with the number to indicate the series.

Rule 4. Statement to be Submitted.] A statement must be filed with the Division of Milk Inspection for every tuberculin tested animal supplying the City of Chicago with milk or milk products. This statement must indicate the number and series given to the animal, which number and series must correspond with the tag or mark worn by the animal. This statenent must also state the age and color of the animal, and any other distinctive marks shown by the aninal. In addition the statement must show the temperature. record of the animal on the lays preceding and following the test, the date and the exact time of taking these 
temperatures and the date and time of making the injection and anount and kind of tuberculin used; the name of the owner and the signature of the person making the test, togetler with the official capacity of said person or persons making the test, and their address. The statement submitted shall also indicate the date of the last tuberculin test made upon the animal and the nethod of making this test, and the length of time that the animal has been in the herd.

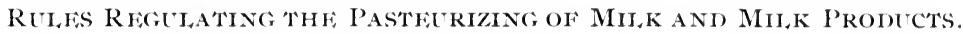

The following rules shall regulate the pasteurizing of milk and milk prorlucts offered for sale, exposed for sale or kept with the intention of selling within the City of Chicago, after January 1st, A. I). 1908 :

Rule 1. Milk'and Skimmed Milk.] Milk and skimmed milk shall not contain more than 100,000 bacteria per cubic centineter from May 1 st to September 30 th, and not over 50,000 bacteria per cubic centimeter between (October 1st and April 30th.

Rule 2. Cream and Ice Cream.] Cream and ice crean shall not contain more than 200,000 bacteria per cubic centimeter froni May 1st to September 30th, and not over 100,000 bacteria per cubic centimeter between October 1st and April 30th.

Rule 3. Milk, Skimmed Milk, Buttermilk, Cream and Ice 'Cream.] An original package of pasteurized milk, skimmed milk, buttermilk, cream or ice cream, exposed to the temperature of the room for 48 hours and stoppered with a sterile cotton plug, shall not show evidences of putrefaction, after being so exposed.

Rule 4. Skimmed Milk and Ice Cream.] Skimmed milk and ice cream shall give a negative test when treated in the following manner:

To $5 \mathrm{cc}$. of the pasteurized product add two drops of a 2 per cent solution of paraphenylenediamin, and one drop of a 2 per cent solution of hychrogen peroxide, and agitate.

Not more than a tinge of blue shall be obtained by this test within 30 seconds after mixing.

Rule 5. Butter.] Butter shall respond to the following test:

25 grams of pasteurized butter placed in a small beaker and lieated by being placed in water at 60 degrees centigrade, the clear butter fat then poured off and the remaining liquid then diluted with an equal volume of water. The mixture thus obtained is now treated with two drops of a 2 per cent solution of paraphenylenediamin and one drop of a solution of 2 per cent hydrogen peroxide.

When thus treated not more than a perceptible blue color shall be obtained within 30 seconds after mixing.

Rule 6. Pasteurizing 'Temperatures.] A11 pasteurized milk, cream, skimmed milk, milk products, and milk and cream used in the produc- 
tion of milk products shall be pasteurized in accordance with the following regulations :

(A) Continuous Pasteurization.] In all continuous pasteurization the milk and cream shall be heated to a temperature which shall be determined and fixed by the Department of Health for each machine at a point corresponding to the temperature required to kill 99 per cent of the bacteria and all pathogenic bacteria contained in the raw product. For this determination ordinary raw nilk containing in the neighborhood of 3,000,000 bacteria shall be used and the pasteurized product shall be collected as it flows from the cooling apparatus.

All continuous pasteurizers shall be equipped with a feeding pipe which is so constructed that the pasteurizer cannot be fed in excess of its normal working capacity ; that is, in excess of the working capacity of the machine at which 99 per cent of the bacteria are killed when the required amount of heat is applied.

All continuous pasteurizers operated outside of the city limits, for the prorluction of pasteurized milk and milk products to be sold in the City of Chicago shall be equipped with an apparatus regulating automatically the supply of steam and lieat, so as to correspond with and produce the requirerl temperature of the outflow of the pasteurized product. These automatic thermo regulators shall be accurate and nust be approved by the Commissioner of Health before being installed.

A recording apparatus shall be installed npon all continnous pasteurizers operated within the city limits so as to record during operation the temperature of the pasteurizerl product as it flows from the heater. The thermoneter of this recording apparatus must be accurate and kept emerged in the 111ilk in such a way that it is not exposed to escaping steam or other heat, except the lieated milk.

The records made by this recording thermometer nust be accurate and nade in a chamber which is kept under lock and key in the control of the Department of Health.

The automatic thermo regulating and recording apparatus may be con1bined into one instrument and it is recommended that all pasteurizers be equipped with both appliances or the combination apparatus.

(B) Held Pasteurization.] Whenever $111 \mathrm{k}$ is held during pasteurization in such a manner that the process of pasteurizing is not a continuous one, namely, a continuous flow of milk through the heating or heat retaining chamber, the process shall be designated as "Held Pasteurization."' Such methods of pasteurization and pasteurization appliances or systems installed and used shall be examined and approved by the Con1missioner of Health, or his duly appointed representatives, when all of the following requirements are fulfilled:

1. When the pasteurized product shows that over 99 per cent of the bacteria and all pathogenic bacteria contained in the raw product have been destroyed. 
2. When the mechanism of the pasteurizer or pasteurizing system is such that the three important elements, namely: the temperature, time of exposure, and the quantity of milk exposed at one time can be readily kept under control and observation by the Department of Health.

3. When the following conditions are complied with:

A uniform heating of 140 degrees F. maintained for 20 minutes; 150 degrees F. maintained for 15 minutes; 155 degrees $F$. maintained for 5 minutes; 160 degrees F. maintained for $1 \frac{1}{2}$ minutes; 165 degrees F. maintained for 1 minute.

The time shall be calculated from the period that the entire quantity reaches the required temperature.

Rule 7. Cooling 'Temperatures.] The pasteurized product shall be cooled at once to a temperature of 45 degrees $\mathrm{F}$. or less. This cooling sliall be so conducted that the pasteurized product is not exposed to the air or other contanination. This cooling apparatus shall be so constructed that it can be readily cleaned and sterilized. 


\title{
APPENDIX C.
}

\author{
DULUTH MILK ORINANCE.
}

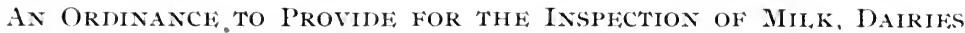

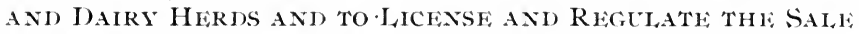

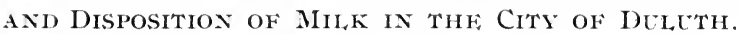

The Common Council of the City of Duluth do ordain as follows :

Section 1. That from and after the passage and approval of this orlinance no person shall engage in the sale or disposition of nillk within the City of Duluth without first having obtained a license so to do in the manner hereinafter provided.

Section 2. Any person desiring a license to engage in the sale or disposition of $111 \mathrm{ilk}$, as provided in section 1 hereof, shall first make application therefor to the Conmon Council by filing with the commissioner of health of the City of Duluth for presentation by hin to the Common Council of said city, an application in writing therefor, which said application shall set forth with reasonable exactness the name and place of residence of the applicant, the exact location or place from which the applicant obtains or is to obtain his milk, and if the applicant is not a producer of milk, then the number of cows in his dairy herd, the name of the person or persons from whom he obtains or is to obtain his nilk for sale or distribution, and if said applicant is a producer of milk, or if he is not a producer of milk, the number of cows in the dairy herd of the person or persons from whom lie obtains or is to obtain his milk: and said application shall further set forth the nanner in which the applicant intends to dispose of liis 111ilk when licensed, according to the provisions of this ordinance, and shall be signed by the applicant, and when received by the comminssioner of health shall be placed on file and the name of the applicant shall be registered in a book of registration kept for such purpose.

Section 3. The filing of the application provided for in the next preceding section shall authorize the applicant to engage in the sale or disposal of milk and to continue in the prosecution of that business, if he shall, at the time of the filing of the application, be engaged in the business of selling or distributing milk, until the Common Council takes action thereon and either issues a license to the applicant or refuses so to do.

Section 4. Any sucl applicant, or any person fron whom such applicant obtains or is to obtain his nilk, shall permit the officers of the 
department of health of the City of Inluth to inspect the dairy and dairy herds of such applicant, or the dairy and dlairy herd of the person or persons from whom the applicant olstains or is to obtain his $111 \mathrm{k}$, together with all appliances and 1nilk vessels used therein, and any refusal upon the part of such applicant or upon the part of the person or persons from whon such applicant obtains or is to obtain lis nilk to pernit the inspection above referred to shall be deened a sufficient ground upon which the Common Council may refuse to issue the license applied for.

Seetion 5. Upon the filing of the application with the commissioner of health, as provided in section 2 thereof, said connunissioner, or an anthorized inspector or veterinary, acting under his instructions, shall proceed, without unnecessary delay, to inspect the dairy and dairy herr of such applicant, or the dairy and dairy herd of the person or persons from whom the applicant obtains or is to obtain his milk for sale or distribution within the corporate limits of the City of Duluth, ancl it sliall be the duty of said comminsioner of health to make or cause to be made, under his direction and supervision, an examination and inspection, not only of each and every animal producing milk for sale or consumption within the corporate limits of sairl City of Duluth, belonging to or controlled by the said applicant or the person from whom said applicant obtains or is to obtain his milk, but also of each and every cow, heifer, bull, steer or calf over the age of six months in the dairy or dairy herd of such person, for the purpose of detecting the presence or absence of tuberculosis or any other contagious or infectious disease, and said con1111issioner of health, or his said authorized inspector, acting under his direction and supervision in making such inspection and examination, is hereby authorized to use what is commonly known as the tuberculin test as a diagnostic agent for the letection of tuberculosis.

Section 6. After such examination and inspection of the dairies and (lairy herds as in the next preceding section provided, an authorized agent of the department of health of the City of Duluth shall tag each and every animal so examined, which tag shall be of such character as to afford a permanent record of such examination, nor shall such tag be altered, mutilated or renoved by any one other than an authorized agent of the health departinent of the City of Duluth, and the result of the same as regards the presence or absence from an infectious or contagious disease, and immediately thereafter and without undue or unnecessary delay the commissioner of health shall present the application in section 2 hereof provided for to the Common Council of the City of Duluth, and shall accompany it with a report which shall contain the result of the examination and inspection of the dairy and dairy herd of the applicant, or of the dairy and dairy herd of the person or persons from whom the applicant obtains or is to obtain lis milk for sale or distribution within the corporate linits of the City of Duluth; and the commissioner of 
health shall also state in such report what disposition, if any, has been made by the applicant or the person or persons from whom the applicant obtains or is to obtain his milk of the animals which were found to be affected with tuberculosis or any other contagious or infectious disease, if any there were, and whether or not any animals so diseased are used by the applicant or the person or persons from whom the applicant obtains or is to obtain his milk for the production of milk for sale or distribution for consumption within the corporate limits of the City of Duluth.

Section 7. The Common Council sliall thereupon, after proper investigation, whether from a consileration of such report or from other sources, adjuclge and determine what applicants may be entitled to obtain a license for the sale or distribution of milk within the corporate limits of the City of Duluth, and shall thereupon by resolution grant the license applied for to such of the applicants as may be, in the opinion of the Common Council, entitled thereto under the provisions of this ordinance.

Section 8. It shall thereupon be the duty of the commissioner of health, upon due notice from the city clerk of the passage of the resolution or resolutions in the next precerling section provided for, to issue a license or licenses to sell or distribute milk within the corporate linrits of the City of Duluth to each applicant named in such resolution or resolutions as is entitled thereto, which said license shall be numbered and signed by the commissioner of health, and a record thereof shall be kept in the book of registration provided for in section 2 hereof, and said license shall be valid and effective for the perior of one year from and after the date of its issuance, and no longer.

Section 9. Each licensee shall cause his name and his place of business and the number of his license to be legibly placed in a conspicuous place on the outer side of all carriages, wagons, sleighs or other vehicles used by lim in the sale or distribution of $111 \mathrm{k}$ within the corporate limits of the City of Duluth, and all licensees who sell milk from stores or shops shall keep their licenses constantly posted in a conspicuous place upon the wall of the room within which such sale of 11 ilk is prosecuted or carried on.

Section 10. No person shall offer or expose for sale, or sell or distribute or deliver for sale or consumption any unclean, impure, unhealthy, unwholesome or adulterated milk, and no person shall keep animals for the production of $m i 1 \mathrm{k}$ for sale or distribution within the corporate limits of the City of Duluth in an over-crowded condition, or in barns or stables or other buildings which are not properly ventilated, or which are in an unfit and unclean condition from any cause, nor shall any person draw or suffer to be drawn milk from animals which are themselves in an unfit or unclean condition, or from animals which are affected with tuberculosis, or any other form of disease, or from animals which are fed either wholly or in part upon fermented distillery waste or decomposed 
brewery grains or the waste of vinegar factories, in a fermented condition, or upon any other form of food which is calculated to produce milk which is unhealthy or unwholesome, or from aninals which are supplicel with water which is impure and unwholesome, nor shall any person keep or suffer to be kept any 111ilk or nilk product intended for sale or distribution in unfit or unclean vessels, nor in any unfit or unclean rom or builling, or in any roon or building userl as a sleeping apartnent or for any otler purpose incompatible with the proper preservation of the cleanliness, wholesonneness or healthy condition of the milk or nilk ressels kept therein, and all milk thus kept or produced is hereby declared to be unclean, inpure, unliealthy and unwholesone 1nilk, within the meaning of this section, and any milk which is shown by analysis to contain a preservative or any other substance or substances of any character whatever not natural or normal constituents of $111 \mathrm{k}$, or to have been deprived either wholly or in part of any constituent naturally or nornally contained in nilk, or which is shown to contain more than eighty-seven (87) per cent of water fluids, or less than thirteen (13) per cent of nillk solids, of which less than three and a half $\left(3 \frac{1}{2}\right)$ per cent sliall be fat, is hereby declared to be adulterated milk within the meaning of this section, and any such unclean, inpure, unhealtly, unwholesome or adulterated 111ilk may be seized and confiscated by the com1nissioner of health or his duly appointed, qualified and authorized inspectors.

Section 11. No person shall, within the corporate linits of the City of Duluth, have in his possession with intent to sell, offer or expose for sale, or sell or deliver for sale or consumption, in any store or place of business, or from any wagon, sleigh, cart or other vehicle used in the distribution or sale of 111ilk, any nilk from which the crean has been removed, or milk commonly known as "skimmed milk," without first marking the can or package containing said milk and from which said milk is delivered to the purcliaser or customer with the words "skimmed milk" in large, plain letters, each letter being at least one inch ligh and a lalf incl wide, and to be placed in such position as to be easily seen when such milk is sold and delivererl.

Section 12. In order to carry out the provisions and purposes of this ordinance, the comminsioner of health, and all other officials, inspectors and employes of the department of health in the City of Duluth, shall have the right at any and all times to enter upon or in the prenises of any person licensed under the provision of this ordinance, to exannine and inspect the dairy and dairy herd of such licensee, and to appropriate a reasonable amount of any milk or milk product in the possession or under the control of such licensee for the purpose of use as samples and for inspection or test, and they shall also have the right to enter upon or into the premises of any person or persons from whom such licensee obtains his milk for sale, to inspect and examine the dairy and dairy herd of such person or persons; and each licensee, under the terins 
hereof, shall give at least three days notice in writing to the connunissioner of health of an intention on his part to obtain his nilk from other persons than those named in his original application, and any failure upon his part so to do, or any refusal upon the part of said licensee or upon the part of the person or persons from whom said licensee obtains lis $111 \mathrm{kl}$, to allow sucli entry or inspection as may be required under the terms of this ordinance sliall be followed by an immediate revocation of the license of such person or persons by the conminssioner of health.

Section 13. It shall be the duty of the commissioner of health to cause the dairy and dairy herd of all licensees hereunder, and the dairies and dairy herds of the person or persons from whom such licensees obtain their milk, to be inspected from time to time, and if the conditions which are required as a pretequisite to obtaining a license under the provisions of this ordinance are not constantly maintained, then it shall be the duty of the commissioner of health to report the same to the Common Council and make such recommendations in regard thereto as he may deem proper.

Section 14. The comminssioner of health n11ay appoint, at such con1pensation as may be fixed upon and determined by the Common Council, such additional inspectors or employes as may be necessary for the purpose of carrying out the provisions of this ordinance, and the salaries of such additional inspectors and other expenses incidental to the enforcement of this ordinance shall be payable out of the general fund, and it is hereby made the duty of the comminssioner of health to enforce the provisions hereof.

Section 15. Any person violating any of the provisions of this ordidance shall, upon conviction thereof, be punished by a fine of not less than Ten (10) Dollars nor nore than Thirty (30) Dollars, or by imprisonment for not less than ten (10) nor more than ninety (90) days, and by the revocation of any license which may have been granted to such persons under the terms of this ordinance, such revocation to be immediately made by the comminssioner of health of the City of Duluth.

Section 16. All ordinances or parts of ordinances inconsistent herewith are hereby repealed.

Section 17. This ordinance shall take effect and be in force from and after its passage and publication.

Passed Dec. 5, 1904.

Approved Dec. 7, 1904.

M. B. Cullum, Attest:

Mayor.

H. W. Cheadre, City Clerk. 


\section{APPENDIX D.}

\section{BIANK FOR REPORTING FXISTENCE OF INFICTIOLS DISEASES.}

DEPARTMENT OF HEALTH, THE CITY OF NHW YORK.

Report of Dairymen to be Filled out and Delivered at Creanery Iivery Saturday Morming.

Date

To the Manager:

Creanlery.

Town.

State.

Sir :

In accordance with the requirements of the Board of Health of the Department of Health of the City of New York in relation to infectious disease $^{*}$ anong milk handlers, I make the following statement upon my honor.

Owner of Farmi.

Operator of Dairy.

Location

No. of Persons in Family.

No. of Persons in Houseliolds of Farm Hands No. of "Summer Boarders",

There are no cases of infectious diseases among any of the above nentioned persons, except as hereinafter stated.

NaMe; OF PATIENT.

DISEASF.

AtThending Physician.

Respectfully,

* The following infectious diseases are to be reported:

Measles

Varicella (Chicken Pox)

Rubella (German Measles)

scarlet Fever

Diphtheria

Erysipelas

Small Pox

Typhoid Fever Fipidemic Cerebro-Spinal Meningitis Tuberculosis (Consumption)

(This report to be kept on file in creamery at least six months.) 


\section{APPENDIX E.}

\section{POSTER FUR IAIRY BARNS.}

TWENTY DAIR SUGCESTIONS WITH SPECIAI, RIFERENCH TO SANITATION.

Tnited States Department of Agriculture, Bureau of Animal Industry, I)airy Division.

THE COWS.

1. Have the herd examined at least twice a year by a skilled reterinarian. I'romptly remove animals suspected of being in barl health. Never add an animal to the leerd until certain it is free from disease, particularly tuberculosis.

2. Never allow a cow to be excited by fast rlriving, abuse, loud talking. or unnecessary disturbance; (lo not expose her to cold or storms more than necessary.

3. Clean the entire body of the cow daily; hair in the region of the udder slould be kept short by clipping.

4. I) not allow any strong-flavored foor, like garlic, cabbage, or turnips, to be eaten, except immediately after milking. Changes in feerl should be marle gradually.

5. Provide fresli pure water in abundance, easy of access and not too cold.

\section{THE STABILS.}

6. Dairy cattle slould be kept in a stable, preferably without cellar or storage loft, and where no other animals are loused.

7. The stable should be light ( 4 square feet of glass per cow) and rly, with at least 500 cubic feet of air space per animal. It should have air inlets and outlets, so arranged as to give good ventilation witl1out drafts of air on cows.

8. The floor slould be tight and constructed preferably of cenent; walls and ceilings slould be tight, clean, free from cobwebs, and whitewashed twice a year. Have as few dust-catching ledges, projections, and corners as possible.

9. Allow no dusty, musty, or dirty litter, or strong-smelling material in the stable. Haul manure to field daily, or store under cover at least 40 feet from stable. Use land plaster daily in gutter and on floor. 
MII, Horsti.

10. Have a light, clean, well-ventilaterl, and screened milk room, located so as to be free from clust and odlors.

11. Milk utensils should be marle of metal, and all joints smoothly soldered. Never allow utensils to become rusty or rough inside. Ise them only for handling, storing, or delivering milk.

12. 'To clean rlairy utensils, use only pure water. First rinse the utensils in warn water. Then wash insicle and out in lot water in which a cleansing material has been dissolved, and rinse again. Sterilize with boiling water or steann. Then keep inverterl in pure air and sun, if possible, until wanted for use.

MIIKING AND HANDI,ING MIIK.

13. Use no dry, dusty food just previous to 111 ilking.

14. The milker should wash lis liands inmediately before milking, and nillk with dry hands. He slould wear a clean outer garment, kept in a clean place when not in use. Tobacco should not lee used while nilking.

15. Wipe the udder and surrounding parts with a clean damp clotl in1. mediately before milking.

16. In milking be quiet, quick, clean, and thorouglı. Commence milking at the same hour every morning and evening, and nilk the cows in the same orcler.

17. If any part of the milk is bloody, stringy, or unnatural in appearance, or if by accident clirt gets into the milk pail, the whole should be rejected.

18. Do not fill cans in the stable. Remove the nillk of each cow at once from the stable to milk roon1. Strain inmediately through cotton flannel or cotton. Cool to $50^{\circ} \mathrm{F}$. as soon as strainerl. Store at $50^{\circ} \mathrm{F}$. or lower.

19. Never mix warn 1111k with that which has been cooled, and do $110 t$ allow willk to freeze.

20. A person suffering from any disease, or who has been recently exposed to a contagious disease, must remain away from the cows and the nilk. 


\section{INDEX.}

\section{A}

Acicl-fast organisms 154

Acidity of milk Tests for

Actinomycosis

Adulteration of milk

Aeration of milk

Amer. Asso. Med. Milk Commissions 157,158

Aner. Pub. Health Asso...141, 152

Ammonia refrigeration … ....25

Analysis of milk $\ldots . . .174$

Antlirax 86

Apparatus, inspection of $\quad 105$

Artificial digestion experiments 188

Aseptic milking _ 4, 8, 37

Asli of 111ilk

176

\section{B}

Babcock test

Bacillus coli communis 27, 55, 152

Bacillus diphtherice

52,115

Bacillus lactimorbi

88

Bacillus lactis viscosus'. $31,32,33$

Bacillus prodigiosus _.............2, 3

Bacillus proteus .................... 55

Bacillus pseudo tuberculosis .....154

Bacillus subtilis

Bacillus typhosus, carriers of, 45, 49

Effect heat upon

Examination of $111 \mathrm{llk}$ and water for

46,152

Germicidal action upon ........36

In milk

45

Bacteria, effect of temperature on 24,34

Growtl of

24,34

In forenilk

In $111 \mathrm{ilk}$

$1,4,23,110,165$

In udder

Killing of

Microscopic rletermination

$$
\text { of. }
$$

On udder

$3,4,6$

Spore-bearing

Bactericide

116

Bacteriological exanination

of millk

115,117

141,165
Numerical determinations

110,141

Interpretation of results.... 150

Bacterium acidi lactici. 27, 28, 133

Bacterium diphtherice, in milk 52

Fffect heat upon $\quad 115$

Examination milk for $\quad 152$

Bacterium lactis acidi ..............26

Bacterium lactis aerogenes . 27, 36

Bacterium tuberculosis

(see tubercle bacilli)

Barns, improvement of _............ 11

Sanitation of $\ldots \ldots \ldots \ldots \ldots$

Barn-yards _..... $\quad \ldots \ldots \ldots \ldots 5$

Beet pulp … $\quad . . .12$

Benzoic acid .................... 166

Berkeley, Cal., tuberculin test ordinance ….. 76, 195

Typhoid epidenic in _...... 49

Bicarbonate of soda …........... 192

Blendedl 111ilk, Federal standard 183

Bloody milk. 138

Borax . 188, 190

Test for ….................... 166

Boric acid ................. 188, 190

Boston, bacteria in $111 \mathrm{ilk}$ of …....24

Milk inspection in … 111

Bottle cap …..................... 167

Sterilization of a........ 16

Varieties of . $\quad 168$

Bottled milk

Bottles ........................ 16, 17

Bottling machines _...................... 16

Bovine tuberculosis …..59, 60, 164

Eiducation concerning 85

In swine … . . . . . 60

Measures against _.............67 67

Milk-borne _...............59

Physical examination for 68

Prevalence of 61

Views of Kocli on _.............. 64

Brewers' grains .............................12

Budde's method of preserving milk 26

Bur. Anim. Ind., score card of

95,107

Buttermilk, Ferleral standard....183 


\section{C.}

Carbohydrates

Carbon dioxide refrigeration 25

Carbonate of sorla

Care, of cow's coat

$\begin{array}{lr}\text { Uilking maclines } & 9 \\ \text { Stables } & \end{array}$

Casein in milk

Cells, tests for (see leucocytes)

Certified milk

74,156

Allount produced ……........168

Certification label ….................167

Clienical examinations .......166

Cost .................................

Fraudulent _..........................168

Package …........................... 167

Sanitary requirements of dairyme11

Standards for

158

169

Charbon ( see anthrax)

Chemical examination of milk 166

Cliemicals as preservatives ..........26

Clicago, pasteurization in ...... 121

Tuberculin test ordinance

76,200

City milk plants, score card 108

Coat of cow.

Collection of samples ….......... 184

Coloring natter 193

Colostrum _... 87

Commercial pasteurization $\quad 118$

Conlmissions, milk $\ldots \ldots \ldots \ldots \ldots \ldots . . .156$

Experts of .................. 164

Field of ...................... 157

Source of autlority ............. 167

Composition of milk $\ldots \ldots \ldots \ldots . . .174$

Fffect of feeding on ..........176

Condensed milk, Fedleral stand-

$$
\text { ard }
$$

Contamination of milk, $1,2,6,45,62$

Significance

Continuous-flow machines $\quad 120$

Contracts, milk

76

Control of milk supply

Cooked taste of milk.

93

115

Cooling milk

$15,25,37,121$

Cowpox ...87

Crean1, alteration by heat

116

Thickening of

193

Crean, Federal standard

184

Cream, evaporated, Federal standard

\section{D}

Dairy Division, work of . 102, 169

Dairymen and commissions ..... 158

Dehorning …........... 86

Delivery of $111 \mathrm{ilk} \ldots \ldots \ldots \ldots$

Diarrhea, death rate $\quad 55$ Fipidemic.....................56

Digestion experiments . $\quad 188$

Diphtlieria, nilk-borne _..........51

Bacilli (see Bacterium)

In Oroville, Cal............... 53

Swab examinations .............167

Diseases of n11an transmitted by 111 ilk 41

Disinfection of stables $\quad 85$

Dispensaries, milk …......... 170

Distillers' grains …… 12

District of Columbia, typhoid

$$
\text { in } 42,47,123
$$

Doane-Buckley test …........ 129

Dulutl, Minn., tuberculin test ordinance . $\quad 76,206$

E.

Fducation of dairymen

Of public 112

Fpidenic diarrhea _................56

Fpidemic diseases and pasteurization

Fpidenic diseases transmitted by milk ........41, 109

Evaporated milk, Federal standard

Examinations, bacteriological 165

Chemical ….................... 166

Fxperts of nilk commissions 164

\section{F}

Fat, in certified nilk

174

And specific gravity ...........180

Babcock test for ….......... 179

Determination of $\quad 179$

Federal standards _...........169, 183

Feeding, effect on composition

of $\mathrm{milk}$

176

Feeds _........12, 17

Fermentation, lactic acid .............26

Filth $\ldots \ldots \ldots \ldots \ldots \ldots$

Flavor of $111 \mathrm{llk} \ldots \ldots \ldots$

Foot and mouth disease …..........88

Forenilk, bacteria in ..................... 5

Formaldehyde .................166, 189

Leach's test for ..........................191

France, dispensaries in _............170

Fraudulent certified milk .............168

Tuberculin test 


\section{(;}

Gastro-intestinal infections

Germicirlal activity

Goat's milk, Federal standard 183

Goat's milk and Malta fever 87

\section{H}

Handling milk

Heat, effect on cream Fiffect on $111 \mathrm{k}$

Heated milk, tests for 166,193

Heating (see pasteurization)

Hehner's test for formaldehyde 191 High-temperature pasteuriz-

$$
\text { ation. }
$$

Hrilrogen peroxicle

Hypoderma bozis

\section{I}

Identification of animals .....75, 80 Inclennification for slaughtered cows 82

Infant feeding and pasteurized milk

Infant mortality

122

Infection, tuberculous

Infectious diseases, blank for

$$
\text { reporting }
$$

Inspected l11ilk $\quad 74,93,112,166$ Inspection, of city nilik plants

106, 111

I)airies …................ 93, 123

Dairy apparatus ................ 105

Water supplies .......................106

Inspectors, qualifications of ......93

Intern. Cong. on Tuberculosis ...66

\section{J}

Japan, tuberculosis in

66

\section{$\mathrm{K}$}

Kocl, views on tuberculosis... 64

\section{L}

Lactic acid fermentation

Leacli's test for formaldehyde 191

Leucocytes in milk 36,134

Stanclards for $127,131,137$

Leucocyte tests 126

Doane-Buckley 129

Savage's 131

Slack's 128

Stewart's
Stokes'

126

'Trom111sdlorff's ....... 131

Live stock industry ....... 59

Low-temperature pasteurization

\section{M}

Nalta fever

Mannmitis in cows $69,86,126,136$

Mangers …....................... 11

Manure, disposal of ........... 11

Tubercle bacilli in .......63 63

Market n11ilk, bacteria in _.....24

'Tubercle bacilli in .......... 63

Ierlical inspection, certified milik

Micrococci in 111ilk ............3, 134

Wicrococous lactis ararians ......... 3

Micrococcus melitensis ............ 87

Micrococcus pyogenes aureus ..... 4

Microscopic estimate of bacteria 151

Microscopic tests of milk _. 126

Milk, adulteration of .... 187

Milk-borne diplitheria _.... $\quad . .51$

Milk-borne epidenilics .......41, 109

Milk-borne scarlet fever ..........54

Milk commissions $\quad 156$

Experts of … 164

Milk, composition of . 23, 174

Milk, contamination of $1,2,6,45,62$

Nilk dispensaries ................ 170

Milk, Federal standard …............ 183

- Milk flavors .......................... 17

Milk, liandling of 15

Milk pail, sliape of …........... 7

Milk room ….............. 12, 16

Milk sediments ...................... 17

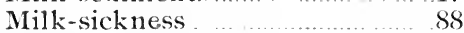

Milk, watering of ….............. 191

Milker $\ldots \ldots \ldots \ldots \ldots \ldots$

Milking machines …………....... 8

Mineral matter .................... 176

Iunicipal sanitary control of 111 ilk 20,93

Of pasteurization …….... 123

(of tuberculin test...... 75

Mycotic stomatitis ............... 88

\section{$\mathbf{N}$}

New York, blank for infectious

diseases

Pasteurization in.........................121

N. Y. S. Coll. of Agri., score card … 97

Numerical determinations (see bacteriological examination) 
$\mathbf{O}$

Ordinances, tuberculin test 72,85 Berkeley, Cal.

Chicago, Ill.

76,195

Duluth, Minn.

76,200

Washington, D. C.

76,206

\section{$\mathbf{P}$}

Palo Alto, typhoirl epirlemic in 46 Parturition disturbances $\quad . .67$

Pasteurization of milk $71,74,114$

Commercial

118

Continuous-flow ................ 120

Efficiency of ................ 119

Higli-temperature ….......... 118

In Chicago ...................... 121

In New York .................. 121

In Washington ................... 73

Low-temperature $\quad 117$

Machines for

117

Pasteurized milk, Federal standard $\ldots . . . \ldots \ldots \ldots . . . . . . . .183$

For infant feeding _.......... 122

Phagocytosis

Physical examination for tuberculosis

Preservatives

Tests for

26, 187

Protein

166,190

Pus cells in milk

174

Putrefaction

\section{Q}

Qualitative determinations

154

R

Refrigeration (see cooling)

Riclinond, Va., score card

Rochester, N. Y., milk dispensaries

103

Rooms, special milking

Ropy 111ilk

\section{$\mathbf{S}$}

St. Louis, certified milk in

Salicylic acirl

167

166,188

Samples, collection of …..... 184

Sampling nilik

177

Sanitary control of barns Of 111ilk

11

Savage's test

93,158

Scalding of utensils 131

Scarlet fever, milk-borne

13

Score card $94,97,107$
Scores of certified dairies $\quad 169$

Scores of dairies in Richmond, Va.

In Waslington, I). C. $\quad 104$

Sediments in milk $\quad 17$

Skim niilk, Fedleral standard 183

Skin milk, condensed, Federal standard $\quad$... 183

Skin1med 111ilk, inclication of 180

Skinming, tests for 192

Slack's test ... 128

Slaugliter of tubercular cows 84

Solicls of 111ilk $\quad 175$

Solids not fat $\quad 180$

Sour milk as foodl 28

Souring of milk 26, 29

Specific gravity .. 177, 180

Spore-bearing bacteria $\quad 116$

Stables, lairy …. $\quad 10$

Sanitation of $\quad 72$

Stanclions .... 11

Standards, Ferleral 169, 183

Stanclards, state 184

Staphylococcus pyogenes aureus ( see Micrococcus pyogenes aureus)

State standards .... $\quad 184$

Sterilization of $111 \mathrm{k} k \ldots \ldots .114$

Of utensils 13

Sterilized milk, Federal standard 183

Stewart's test .......... 127

Stokes' test . ........... 126

Strainers ........................ 15

Strainer pails $\quad 7$

Straining, effect of $\ldots \ldots \ldots . .8,17$

Streptococcus in gastro-intestinal infections $\quad 55$

In manmitis ........... 4,126

In milk .............. 4,133

Determination of 154

Streptococcus lacticus $\quad 26,27,133$

Streptococcus pyogenes …… 4

Strippings $\ldots$

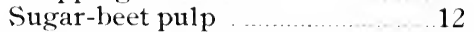

Suppuration $\ldots \ldots \ldots \ldots \ldots \ldots \ldots$

Swine, tuberculosis in ........60

\section{T}

Taints in milk

15,17

Teniperature, effect on luacterial growtl

24,34

Interpretation of 79

Temperature standard of milk 109 Temperature in tuberculin test 


$\begin{array}{lr}\text { 'Tests, 'Babcock's } & 179 \\ \text { Doane-Buckley } & 129 \\ \text { Helner's } & 191 \\ \text { Leach's } & 191 \\ \text { Hicroscopic } & 75 \\ \text { Municipal } & 131 \\ \text { Savage's } & 128 \\ \text { Slack's } & 127 \\ \text { Stewart's } & 126 \\ \text { Stokes' } & 131 \\ \text { Trommsdorff's } & \\ \text { Tuberculin (see tuberculin } & \\ \text { test) } & 193\end{array}$

Thickening agents 193 Time in pasteurization ……… 117 'Toxic milk

30

Toxins

55

'Transportation of milk

25

'Trommisdorff's test

131

'Tubercle bacillus, bovine in man 64 Effect of heat upon ….... 115

In manure

63

In milk $62,63,153$

Types of 63

Tubercular animals

Tuberculin $71,77,79$

Tuberculin test $71,72,75,165$

Application of

Limitations of

Ordinances (see ordinances)

Tuberculosis, and milk supply

Bovine

.59

Cliannels of infection

Disinfection for

In Japan

In swine

91

31
79

3

$\begin{array}{cr}\text { Yrlder, bacteria in } & 1,7 \\ \text { Cleansing of } & 6\end{array}$

Contanination from exterior 6

Diseases of .... 86, 126

Tuberculosis of $\quad 62,69$

U. S. Dept. Agri., poster …212

Ltensils, cleansing of $\quad 13$

Construction of $\quad 15$

Inspection of $\quad 105$

\section{V}

Veterinary inspection _. 164

Vital qualities of milk $\quad 116$

\section{W}

Washington, control of tuberculosis

Milk supply..

Score card ………....123

Wåter supply of dairies _... 106

Watered 111ilk, indication of ... 191

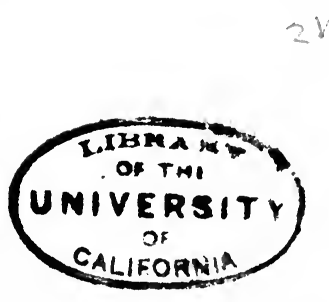





THIS BOOK IS DUE ON THE LAST DATE STAMPED BELOW

AN INITIAL FINE OF 25 CENTS WILL BE ASSESSED FOR FAILURE TO RETURN THIS BOOK ON THE DATE DUE. THE PENALTY WILL INCREASE TO $5 O$ CENTS ON THE FOURTH DAY AND TO \$1.00 ON THE SEVENTH DAY OVERDUE.

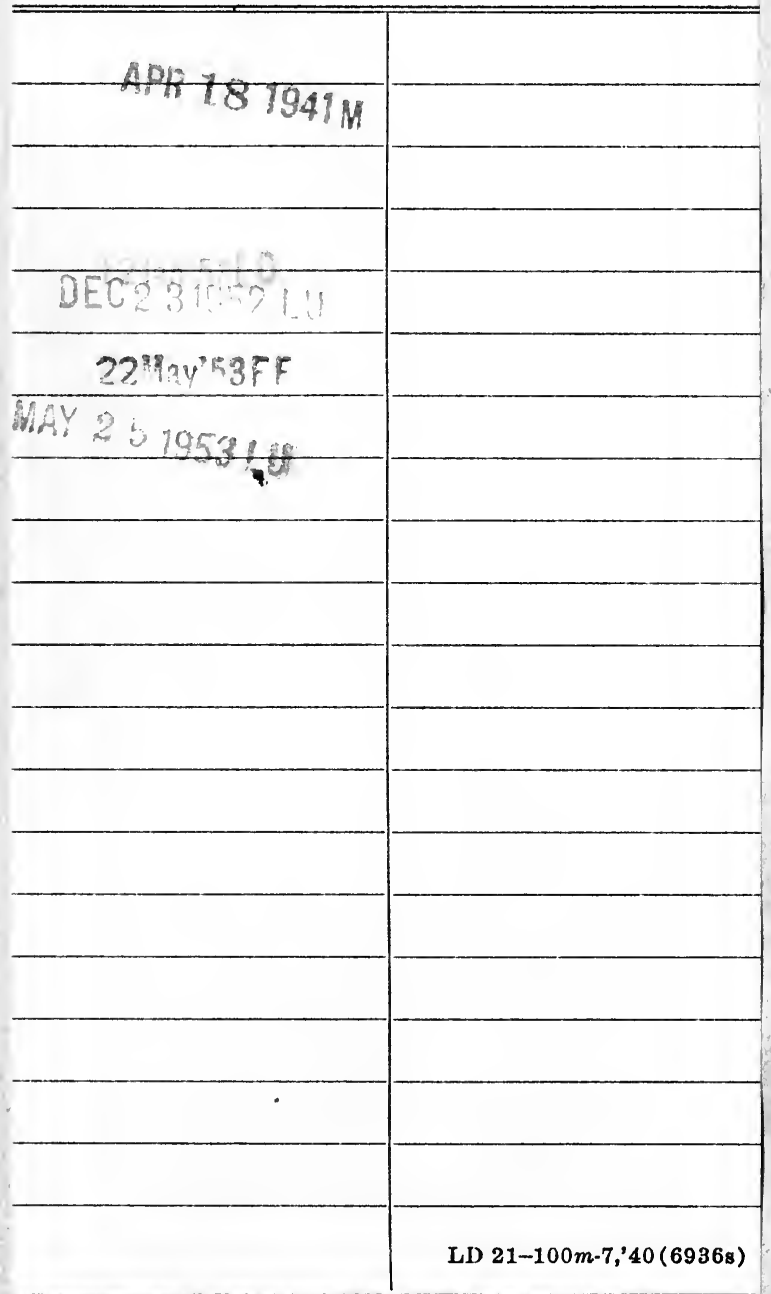


YC 6ićó8

THE UNIVERSITY OF CALIFORNIA LIBRARY 
